\title{
Mechanisms of magma emplacement in the upper crust
}

\author{
Dissertation \\ zur Erlangung des Doktorgrades \\ der Mathematisch-Naturwissenschaftlichen Fakultäten \\ der Georg-August-Universität zu Göttingen
}

vorgelegt von

Steffi Burchardt

aus Nordhausen 
D 7

Referent: Prof. Dr. Gerhard Wörner Geowissenschaftliches Zentrum der Georg-August Universität Göttingen

Korreferent: Dr. Thomas R. Walter

Helmholtz-Zentrum Potsdam, Deutsches Geoforschungszentrum

Tag der mündlichen Prüfung: 
"Science meant looking - a special kind of looking. Looking especially hard at the things you didn't understand. [...] just asking questions, finding the questions that would unlock the door to the next question and the question beyond that."

Robert Charles Wilson

"Darwinia" 

My time as a PhD student has been a hard but rewarding journey. Many people have helped me travel along this road, the end of which (this thesis) would not have been reached without their support and company.

First of all, I thank Gerhard Wörner for taking over the main supervision of my work, for dealing with the related formalities, for his support in getting funding, and for giving me the chance to take part in the field trip to Chile.

Secondly, I thank Thomas Walter for the good collaboration over the years, for introducing me to analogue modelling, for funding and supervising my experiments in Potsdam, and for inspiring and challenging me in our discussions.

Furthermore, I have to express my heartfelt gratitude to David Tanner for teaching me so much about 3D modelling, structural geology, and punctuation, for showing me how exhausting, dangerous, and satisfying good field work can be, for the opportunity to work with him on faults, and for innumerable funny moments in impossible places.

I also thank Axel Vollbrecht for his patience, financial support, personal and scientific advice, and for inspirational discussions. Together with Bernd Leiss and Klaus Wemmer and other colleagues of the Departments of Structural Geology and Isotope Geology at Göttingen, Axel was a valuable support for me during difficult times and demonstrated to me how important collegiality and friendship are to produce good science.

In addition, I am grateful for the support I received from Bent Hansen, Werner Kreisel, and Brigitte Groneberg, which enabled me to pursue my research in spite of all difficulties.

During my PhD journey I was cordially welcomed by the members of the Departments of Geochemistry and Mineralogy at Göttingen, especially Sharon Webb, Burkhard Schmidt, Roland Stalder, Magdalena Banaszak, and Wencke Wegner. Their views of my research from a different perspective have broadened my horizon.

Mike Reich and the staff of the Geosciences Museum Göttingen are acknowledged for their help with the creation of the "analogue" model of the Slaufrudalur Pluton.

I am also grateful to Marie-France Hesse, Brigitte Hinz, Ines Ringel, and Gudrun Asic for their help with things administrative.

The members of the Volcanotectonics Research Group and Sections 2.1 and 3, especially Katja Müller, Madhi Motagh, Manoochehr Shirzei, Judith Sippel and Tina Lohr, made me feel very welcome at GFZ Potsdam. In addition, I highly appreciate the assistance of Matthias Rosenau, Thomas Ziegenhagen, Günther Tauscher, Frank Neumann, Nicolas Le Corvec, Baptiste Scholly, and Andrea Wittek with my experiments at the Analogue Laboratory. 
The manuscripts included in this thesis greatly benefited from the thoughtful, critical, and constructive reviews of Arnau Folch, Thierry Menand, Joan Martí, Scott Paterson, Allen Glazner, and several anonymous persons, as well as from inspiring discussions with Eoghan Holohan. I also thank Nobu Geshi, Takao Ohminato, and Bogdan Emescu for providing and organising the seismic data of Miyakejima.

Furthermore, I sincerely thank Ludvik Gustafsson for passing on his passion for the Dyrfjöll volcano to me, for pleasant field company, and for productive collaboration.

The German Academic Exchange Service (DAAD) gave me financial support for my field work in Iceland. In connection with this, I thank Gudmundur Omar Fridleifsson for funding support, inspiration, and for sharing my passion about extinct Icelandic volcanoes.

During my years in Göttingen, and especially during the years of my $\mathrm{PhD}$, my friends at the university and at home, in particular Stefanie Huhn, Nicole Nolte, Mathias Nestler, Malte Drobe, Sebastian Wagner, France Albero, Katharina Heise, Wiebke Bäro Alexander Gehler, and Ronald Liesegang, have held me from losing the grip on my private life. Special thanks go to Nadine Friese with whom I could always discuss private and scientific things and who prevented me from going mental more than once. Thank you all for your friendship!

I would also not have reached this point without the support from my parents, grandparents, and my sister Ines who were always there for me when I needed them and who accepted that I have had too little time for them during my $\mathrm{PhD}$.

Finally, I want to thank Michael Krumbholz for his help and the time he spent with me in the field, for his support and patience throughout my $\mathrm{PhD}$. 


\section{Abstract}

The mechanisms that control magma emplacement in the upper crust are characterised by brittle failure of the host rock and subject to the influence of magma. This thesis is a compilation of several case studies that address different aspects of magma emplacement by brittle mechanisms.

Chapter 3 outlines the results of a field study of the Njardvik Sill in the Tertiary Dyrfjöll Volcano in Northeast Iceland. This small basaltic sill provides insight into the mode of its emplacement along the interface between two mechanically contrasting materials, its feeding relationships with several inclined sheets, as well as the circumstances of its growth by episodic magma supply. Once initiated, the Njardvik Sill furthermore influenced the stress field in its surroundings that resulted in the diversion of subsequently injected inclined sheets into units of the sill. The results of detailed field analyses served as the basis for a simple numerical model of the mechanical conditions for the emplacement of the first sill unit. The study of the Njardvik Sill thus provides insight into the mechanism of sill emplacement particularly with regards to feeding relations, mechanical conditions for sill initiation, the influence of the magma-supply rate, and the mechanical effect of a sill on its surroundings.

Chapter 4 documents a series of scaled analogue experiments on the kinematics of ring faulting above a deflating magma reservoir processed using digital image correlation and strain-analysis techniques. The results show a sequential process of ring faulting characterised by initiation, propagation, and interaction of several sets of ring faults. The strain analysis gives detailed insight into the mode of initiation, propagation, and final deactivation of individual ring faults and displacement transfer between successive sets of ring faults. Based on the experimental results, an enhanced understanding of the process of underground ring faulting that preceded the caldera collapse in Miyakejima Volcano, Japan, in 2000 and documented by seismic monitoring can be gained.

Chapter 5 describes the results of a detailed structural study of the emplacement of the Slaufrudalur Pluton, Southeast Iceland. As the largest granitic intrusion exposed in Iceland, the Slaufrudalur Pluton is exposed in three dimensions in five glacial valleys, which allowed a high-precision GPS mapping of its margins. Based on the GPS mapping, the three-dimensional shape of the pluton could be reconstructed. Chapter 5.1 deals with this new technique and discusses which implications can be derived from this approach about the mode of emplacement of a pluton. Chapter 5.2 outlines the results of a detailed field study of the contact between the Slaufrudalur Pluton and its basaltic host rocks in addition to the pluton's inner structure to deduce the mechanisms that controlled its emplacement. From this, it is demonstrated that the exposed 8 to $10 \mathrm{~km}^{3}$ of the pluton were emplaced by a combination of cauldron subsidence and magmatic 
stoping. However, the derived emplacement model shows that the mechanism of cauldron subsidence was modified by the structure of the host rock and regional tectonic forces. In addition, detailed insight into the mechanism of magmatic stoping could be gained by a study of the roof structures of the Slaufrudalur Pluton. Furthermore, using the three dimensional model of the pluton's shape and the knowledge of the roof structure, it was possible to balance the volumetric contribution of individual emplacement mechanisms.

The electronic appendix (attached as CD) includes movies of experiments in Chapter 4 and a movie of the three dimensional model in Chapter 5.1, as well as the already published version of Chapter 3 .

\section{Zusammenfassung}

Platznahmemechanismen von Magma in der Oberkruste werden durch bruchhafte Prozesse kontrolliert. Die vorliegende Arbeit betrachtet verschiedene Aspekte der Magmenplatznahme durch bruchhafte Mechanismen anhand mehrerer Fallstudien.

In Kapitel 3 werden die Ergebnisse von Geländeuntersuchungen des Njardvik-Sills im Tertiären Dyrfjöll-Vulkan in Nordostisland beschrieben. Dieser kleine, basaltische Lagergang bietet Einblicke in die Mechanismen seiner Platznahme entlang einer Trennfläche zwischen zwei mechanisch unterschiedlichen Materialien, die Beziehung zu den ihn speisenden Kegelgängen, sowie die Umstände seines Wachstums aufgrund episodischen Magmennachschubs. Zudem beeinflusste der Njardvik-Sill unmittelbar nach seiner Bildung das ihn umgebende Spannungsfeld, sodass nachträglich injizierte Gänge als weitere Einheiten des Sills umgelenkt wurden. Die Resultate der detaillierten Geländeuntersuchungen dienten als Grundlage eines einfachen, numerischen Modells zur Analyse der mechanischen Bedingungen der Platznahme der ersten Einheit des Lagergangs. Die Studie des Njardvik-Sills erlaubt daher Rückschlüsse auf den Platznahmemechanismus von Lagergängen im Allgemeinen besonders in Bezug auf die Art der Magmenförderung, die mechanischen Bedingungen zur ursprünglichen Bildung eines Sills, die Bedeutung der Magmenförderrate und den Einfluss, den ein Lagergang auf das Spannungsfeld seiner Umgebung ausübt.

In Kapitel 4 werden die Ergebnisse einer Serie skalierter Analogexperimente über die Bildung von Ringstörungen über einer sich entleerenden Magmakammer, die mit Hilfe digitaler Bildkorrelation und Verformungsanalyse ausgewertet wurden, ausgeführt. Die 
Ergebnisse zeigen, dass der Prozess der Entwicklung von Ringstörungen durch eine Abfolge von Bildung, Wachstum und Interaktion verschiedener Ringstörungssets gekennzeichnet ist. Die Verformungsanalyse erlaubt detaillierte Einblicke in die Bildung, das Wachstum und Deaktivierung einzelner Ringstörungen, sowie die Übertragung der Aktivität auf nachfolgende Ringstörungen. Die experimentellen Ergebnisse ermöglichen ein verbessertes Verständnis des durch seismische Überwachung dokumentierten Prozesses der Ringstörungsentwicklung im Untergrund, der dem Calderakollaps im Miyakejima-Vulkan 2000 in Japan vorausging.

Kapitel 5 beschreibt die Ergebnisse einer detaillierten, strukturellen Untersuchung der Platznahme des Slaufrudalur-Plutons in Südostisland. Als die größte granitische Intrusion Islands ist der Slaufrudalur-Pluton entlang mehrerer ehemaliger Gletschertäler hervorragend aufgeschlossen. Dies ermöglichte die dreidimensionale Kartierung des Kontaktes des Plutons zum basaltischen Nebengestein mit Hilfe hochauflösenden GPS, auf deren Grundlage eine Rekonstruktion der Form des Plutons erstellt wurde. In Kapitel 5.1 wird diese erstmals angewendete Methode im Detail erläutert. Zudem wird diskutiert, welche Schlussfolgerungen sich daraus in Bezug auf die Platznahme eines Plutons ziehen lassen. Kapitel 5.2 beschreibt die Ergebnisse einer Analyse des Kontaktbereiches sowie der Internstruktur des Slaufrudalur-Plutons, auf deren Grundlage die dominierenden Platznahmemechanismen abgeleitet werden konnten. Dementsprechend wird gezeigt, dass mindestens $8 \mathrm{~km}^{3}$ granitischen Magmas durch eine Kombination von Cauldron-Subsidenz und magmatischem Stoping intrudierten. Dieses Platznahmemodell erfordert jedoch eine Modifikation des Cauldron-SubsidenzMechanismus aufgrund der Struktur des Nebengesteins und des regionalen tektonischen Regimes. Weiterhin konnten durch die detaillierte Analyse der Dachstruktur des Plutons weitere Einblicke in den Mechanismus des Stoping gewonnen werden. Außerdem war es unter Verwendung des dreidimensionalen Modells des Slaufrudalur-Plutons und unter Berücksichtigung der Dachstruktur möglich, den Beitrag individueller Platznahmemechanismen zu quantifizieren.

Der elektronische Anhang (als CD beigefügt) enthält neben Filmen der Experimente in Kapitel 4 und einem Film des dreidimensionalen Plutonmodells in Kapitel 5 die bereits publizierte Version von Kapitel 3. 
Acknowledgements $\quad$ i

Abstract iii

Zusammenfassung $\quad$ iv

Table of contents vi

List of figures and tables $\quad$ ix

1. Introduction 1

1.1 Preface 1

1.2 Mechanisms of magma emplacement 2

1.2.1 Magma formation, segregation, and ascent 2

1.2.2 Magma emplacement 3

1.2.2.1 Parameters controlling magma emplacement 3

1.2.2.2. Types of emplacement mechanisms 5

- Diapirism and ballooning 5

- The formation of sills, laccoliths, and lopoliths 6

- Ring faulting, cauldron subsidence, and caldera collapse $\quad 8$

- Magmatic stoping 9

$\begin{array}{ll}1.3 \text { Overview of Chapters 3, 4, and } 5 & 10\end{array}$

1.4 References 12

2. Geological and tectonic framework 21

2.1 Active tectonics in Iceland 21

2.1.1 Mantle plume - Mid-ocean ridge interaction 21

$\begin{array}{ll}2.1 .2 \text { Crustal structure } & 21\end{array}$

2.1.3 Structure of the rift zone 22

2.1.4 Temporal evolution of the rift zone 23

2.1.4.1 Stratigraphic classification of Iceland 23

2.1.4.2 Rift jumps 24

2.2 Structure of Tertiary rift zones in East Iceland 26

2.2.1 Determination of the level of erosion 26

2.2.2 Structure of East Iceland: Extinct volcanic systems 27

2.3 Significance for this study 28

2.4 References 28 
3. New insights into the mechanics of sill emplacement provided by field 31 observations of the Njardvik Sill, Northeast Iceland

Abstract

3.1 Introduction 32

3.2 Geological setting 33

3.3 The Njardvik Sill 34

3.4 Numerical modelling 36

3.5 Emplacement model $\quad 40$

3.6 Discussion 43

3.6.1 Mechanisms of sill emplacement 43

3.6.2 Dykes as feeders for sills 44

$\begin{array}{ll}\text { 3.6.3 Sills as possible magma chambers } & 45\end{array}$

$\begin{array}{ll}3.7 \text { Conclusions } & 46\end{array}$

$\begin{array}{ll}3.8 \text { References } & 47\end{array}$

4. Miyakejima caldera collapse simulated in experiments: Digital Image 51 Correlation analyses reveal caldera ring-fault propagation, linkage, and interaction

Abstract 51

4.1 Introduction $\quad 51$

4.1.1 The Miyakejima caldera-collapse sequence $\quad 52$

4.1.2 Structural architecture of ring faults $\quad 54$

4.2 Analogue experiments $\quad 56$

4.2.1 Experimental setup and scaling $\quad 56$

4.2.2 Digital image processing results $\quad 58$

4.2.3 Comparison of experimental structures to Miyakejima chronology $\quad 61$

4.3 Discussion 63

$\begin{array}{ll}4.4 \text { Conclusions } & 65\end{array}$

4.5 References 66

$\begin{array}{ll}4.6 \text { Appendix } & 69\end{array}$

4.6.1 Previous experiments on inward- and outward-dipping ring faults $\quad 69$

$\begin{array}{ll}\text { 4.6.2 Experimental scaling } & 69\end{array}$

$\begin{array}{ll}\text { 4.6.3 Digital Image Correlation (DIC) method details } & 70\end{array}$

$\begin{array}{ll}\text { 4.6.4 The influence of the chamber aspect ratio } & 71\end{array}$

$\begin{array}{ll}\text { 4.6.5 Electronic appendix - movies } & 72\end{array}$

$\begin{array}{ll}\text { 4.6.6 References } & 73\end{array}$ 
5. Emplacement of the Slaufrudalur Pluton, Southeast Iceland 75

5.1 Mode of emplacement of the Slaufrudalur Pluton, Southeast Iceland, 75 inferred from three-dimensional GPS mapping and model building

$\begin{array}{ll}\text { Abstract } & 75\end{array}$

$\begin{array}{ll}\text { 5.1.1 Introduction } & 75\end{array}$

$\begin{array}{ll}\text { 5.1.2 Geological setting } & 77\end{array}$

5.1.3 Structural field studies and three-dimensional mapping 78

5.1.4 Reconstruction of the three-dimensional shape of the pluton 81

5.1.5 Interpretation and discussion: Implications for the mode of 83 emplacement

$\begin{array}{ll}\text { 5.1.6 Discussion } & 86\end{array}$

$\begin{array}{ll}5.1 .7 \text { Conclusions } & 88\end{array}$

5.1.8 References $\quad 88$

5.2 Interplay between different mechanisms controlling the emplacement of 91 the Slaufrudalur Pluton, Southeast Iceland

$\begin{array}{ll}\text { Abstract } & 91\end{array}$

$\begin{array}{ll}5.2 .1 \text { Introduction } & 91\end{array}$

$\begin{array}{ll}5.2 .2 \text { Geological setting } & 92\end{array}$

$\begin{array}{ll}5.2 .3 \text { Results } & 95\end{array}$

5.2.3.1 Shape of the Slaufrudalur Pluton on map scale $\quad 95$

5.2.3.2 Cross-sectional shape of the Slaufrudalur Pluton 96

5.2.3.3 Features of the roof contact 100

$\begin{array}{ll}\text { 5.2.3.4 Internal structure } & 103\end{array}$

$\begin{array}{ll}5.2 .4 \text { Interpretation and discussion } & 105\end{array}$

$\begin{array}{ll}\text { 5.2.4.1 Emplacement mechanisms } & 105\end{array}$

- Cauldron subsidence 105

$\begin{array}{ll}\text { - Magmatic stoping } & 107\end{array}$

5.2.4.2 Correlation with other plutonic complexes in the area $\quad 111$

$\begin{array}{ll}5.2 .5 \text { Conclusions } & 112\end{array}$

$\begin{array}{ll}5.2 .6 \text { References } & 113\end{array}$

6. Summary and outlook $\quad 117$

$\begin{array}{ll}\text { 6.1 Summary and discussion of Chapter } 3 & 117\end{array}$

6.2 Summary and discussion of Chapter $4 \quad 118$

6.3 Summary and discussion of Chapter 5 119

$\begin{array}{ll}6.4 \text { Outlook } & 120\end{array}$

$\begin{array}{ll}6.5 \text { References } & 121\end{array}$

$\begin{array}{ll}\text { Curriculum Vitae } & 125\end{array}$ 


\section{Chapter 1}

Figure 1.1 Schematic illustration of the magmatic cycle with special emphasis on magma-emplacement mechanisms.

\section{Chapter 2}

Figure 2.1 Geological map of Iceland with rift zones.

Figure 2.2 Map of the volcanic systems of Iceland.

Figure 2.3 Geological map of East Iceland with extinct volcanic systems. 25

Figure 2.4 The Tertiary lava pile of East Iceland and methods to determine the level of erosion.

Figure 2.5 Schematic illustration of structures associated with volcanic 27 systems.

\section{Chapter 3}

Figure $3.1 \quad$ Location of the Njardvik Sill in Northeast Iceland.

Figure 3.2 Outcrop view of the Njardvik Sill. 34

Figure 3.3 Western margin of the Njardvik Sill with feeder sheets. 35

Figure 3.4 Units of the Njardvik Sill. 35

Figure 3.5 Cross-cutting relations of inclined sheets and the Njardvik Sill. 36

Figure 3.6 Schematic illustration of the evolution of the Njardvik Sill. 37

Figure $3.7 \quad$ Geometry of the numerical model of sill initiation. 38

Figure 3.8 Contours of the minimum principal compressive stress $\sigma_{3}$. 39

Figure $3.9 \quad$ Contours of the von Mises shear stress. 40

Figure 3.10 Trajectories of the maximum principal compressive stress $\sigma_{1}$. 41

\section{Chapter 4}

Figure 4.1 Distribution of seismic events preceding caldera collapse on 53 Miyakejima Island, Japan, 2000, and SAR images of the evolution of the caldera at the surface.

Figure 4.2 Chronology of the events related to caldera collapse in Miyakejima 54 Volcano in 2000.

Figure 4.3 Seismic activity below the summit of Miyakejima Volcano before and during caldera collapse in 2000.

Figure 4.4 Setup of analogue experiments and concept of the Digital Image 57 Correlation (DIC) technique.

Figure 4.5 Experimental results of the rotational strain in experiment no. 
2D_15-110 with a roof aspect-ratio of 0.6.

Figure 4.6 Experimental results of the rotational strain in experiment no. 60 2D_15-118 with a roof aspect-ratio of 1.54 .

Figure 4.7 Comparison of seismicity associated with caldera collapse in 62 Miyakejima Volcano and experimental results.

Figure 4.8 Results of ring shear test of the crustal-analogue material used. $\quad 70$

Figure 4.9 Schematic illustration of the evolution of ring faults for low roof 71 aspect-ratios.

Figure 4.10 Schematic illustration of the evolution of ring faults for high roof 72 aspect-ratios.

Figure 4.11 Synthesis of all experiments showing the correlation between 72 successive ring-fault evolution and roof aspect-ratio.

Table 4.1 Compilation of the results of previous numerical and analogue 69 experiments of ring faulting.

Table 4.2 Results of ring shear test of the crustal-analogue material used. $\quad 70$

Table 4.3 Results of ring shear test of the crustal-analogue material used. $\quad 70$

\section{Chapter 5}

Figure 5.1 Location and map of the Slaufrudalur Pluton, Southeast Iceland. 76

Figure 5.2 Outcrop features of margin and interior of the Slaufrudalur Pluton 79 exposed in Thorgeirstadadalur.

Figure 5.3 Features of the roof contact of the Slaufrudalur Pluton exposed on 80 the southern slopes of the Skeggtindar Ridge.

Figure 5.4 Three-dimensional model of the reconstructed shape of the 81 Slaufrudalur Pluton.

Figure 5.5 Compilation of cross sections through the three-dimensional model in Fig. 5.4.

Figure 5.6 Section along strike through the three-dimensional model in Fig. 5.4 .

Figure 5.7 Orientation of the surfaces of the three-dimensional model in Fig. 5.4 .

Figure 5.8 Tectonic map of Southeast Iceland and the Lón area.

Figure 5.9 Map of the Slaufrudalur Pluton.

Figure 5.10 Three-dimensional model and map-view shape of the Slaufrudalur 96 Pluton.

Figure 5.11 Cross section of the Slaufrudalur Pluton. 97

Figure 5.12 Roof and wall contacts and associated structures of the 98 Slaufrudalur Pluton exposed on the Bleikitindur Ridge.

Figure 5.13 Features of the roof contact of the Slaufrudalur Pluton. 
Figure 5.14 Thin section of a sample of the roof contact of the Slaufrudalur 102 Pluton.

Figure 5.15 An outcrop characterised by a high abundance of basaltic xenoliths 104 in Endalausidalur.

Figure 5.16 Emplacement model for the Slaufrudalur Pluton. 


\section{Introduction}

\subsection{Preface}

The so-called magmatic cycle (Marsh, 1989) describes the evolution of magmatic systems as the succession of magma formation, segregation, ascent, emplacement as a magma chamber, and, eventual, eruption (Fig. 1.1). In general, the emplacement of plutons and preceding magmatism, especially of granitic composition, contributes to crustal growth and has played a major role in the formation of the continental crust, crustal recycling, and the geochemical differentiation of the Earth (e.g. Rudnick, 1995; Albarede, 1998; Hawkesworth and Kemp, 2006; Kemp and Hawkesworth, 2006).

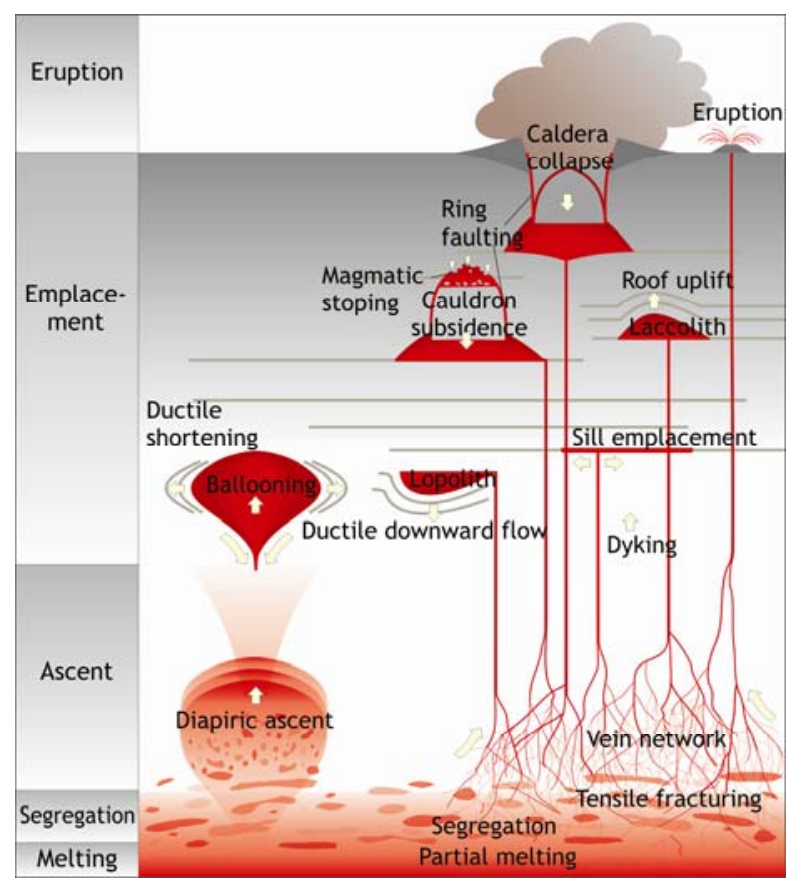

Figure 1.1 Schematic illustration of the magmatic cycle at different crustal levels with the main stages of melt generation, segregation, ascent, emplacement, and eruption.
In addition, the emplacement of magma into the uppermost kilometres of the crust is a prerequisite for the formation of magma chambers that represent sites of magma storage and differentiation and the source for surface volcanism.

In this context, shallow magma emplacement is of major importance for secondary effects such as the formation of mineral deposits (e.g. of porphyry-copper type), geothermal fields, the maturation of hydrocarbon reservoirs in sedimentary basins (e.g. Jones et al., 2007), and even global climate change (Svensen et al., 2008).

This thesis focuses on the mechanical aspects of emplacement of magma, limited to the upper, brittle crust and addresses the following general questions:

(1) Which mechanisms control magma emplacement in the upper crust?

(2) In which way is the emplacement of magma influenced by the structure of the host rock?

(3) In which way does the emplacement influence the host rock?

(4) How can larger magma bodies form?

This thesis is a compilation of several projects dealing with mechanisms of magma emplacement in the upper, brittle crust. Each project addresses a different aspect of this topic on the basis of different methods, such as numerical and analogue modelling, and field examples from Iceland. As an introduction to the topic, Section 1.2 gives an overview of the 
mechanisms controlling magma emplacement, while Section 1.3 explains how each of the projects aims to enhance knowledge about emplacement mechanisms in the upper crust. Since the field examples are located in Iceland, Chapter 2 gives an overview of the geological and tectonic framework of Iceland.

Chapters 3, 4, and 5 have been submitted for publication to international peerreviewed scientific journals or are already published. A remark on the state of progress of each publication precedes each chapter. Finally, Chapter 6 gives a summary of the results of each project and discusses them in the context of stateof-the-art research. Furthermore, it provides an outlook on possible future research areas and topics.

\subsection{Mechanisms of magma emplacement}

Since the stage of magma emplacement is inevitably interlinked with other processes of the magmatic cycle (Fig. 1.1), Section 1.2.2 gives a short overview of magma formation, segregation, and ascent. Section 1.2.3 summarises mechanisms controlling magma emplacement and the parameters that influence these mechanisms.

1.2.1 Magma formation, segregation, and ascent

Magma formation in the Earth's crust is mainly a result of pressure decrease or the addition of volatiles. Initial melting occurs along grain boundaries. As soon as a continuous film of melt is established along the grain boundaries (Jurewicz and Watson, 1985), melt starts to migrate. This is called the first percolation threshold (Vigneresse et al., 1991). At a low melt fraction above the first percolation threshold, melt segregation, i.e. the separation of melt from its source rock, depends on the viscosity of the melt and its distribution in relation to the structure of the source rock (McKenzie, 1984), host-rock permeability, as well as the presence of deformation. Several segregation mechanisms are possible: (1) gravitational compaction of the source rock (McKenzie, 1984, 1985); compaction of the source rock by textural maturation (Miller et al., 1988; Niemi and Courtney, 1983); (3) buoyant ascent of small melt pockets (Fyfe, 1970; 1973); and (4) deformation-assisted extensional fracturing or collection of melt in locally dilatant regions by filter pressing of ductile layers. If the melting process continues and melt accumulates in the source region, the second percolation threshold can be reached (van der Molen and Paterson, 1979; Vigneresse et al., 1991) when, at a melt percentage of 26 to $30 \%$, the solid matrix starts to break down. The melt then starts to escape from its source rock when the buoyancy forces of the magma exceed the yield strength of the surrounding rock ${ }^{1}$. Buoyancy as the main driving force is a result of the

\footnotetext{
${ }^{1}$ For crustal melting, the $\mathrm{H}_{2} \mathrm{O}$ content of the melt can also influence if the melt can rise sufficiently to intrude at shallower crustal levels. $\mathrm{H}_{2} \mathrm{O}$-saturated melts of granitic composition will intersect the solidus curve as they rise and thus solidify at depth (see e.g. Winter, 2001).
} 
Rayleigh-Taylor instability of inversely density-stratified layers.

However, in most cases, convection is initiated in the source area even before the second percolation threshold is reached as a result of a decrease in the bulk density due to partial melting.

Within the ductile lower and mid-crust, diapiric ascent is the main mechanism of magma transport and effective as long as, through ductile flow and aided by deformation, the matrix moves fast enough to accommodate the volume of extruded magma (Ribe, 1987; Cooper, 1990). However, since at high melt percentages thermal convection tends to homogenise the partially molten region and since diapiric ascent is a slow process, the efficiency of diapirism at higher crustal levels is doubted. Therefore, Clemens and Mawer (1992), Rubin (1993), and Petford et al. (1994) argue that magma transport through fractures is a far more efficient mechanism, especially for magmas of granitic composition. Tensile fracturing (vein and dyke formation) is induced even before the second percolation threshold is reached by the local increase in pore-fluid pressures e.g. by a positive volume change during melt generation in dry granitic systems. Vein networks develop, drain the source region of melt, and feed larger dykes. According to Marsh (1984) and Mahon et al. (1988), magma transport through fractures is about 100 times faster than diapiric ascent. The importance of tensile fracturing increases with decreasing crustal depth. Other mechanisms that play a role during focussing of magma flow are the formation of shear zones along original rheological discontinuities, deformation causing anisotropies in the permeability structure of the source region, and localised mineral reactions forming reaction channels (Daines, 2000).

\subsubsection{Magma emplacement}

The magmatic cycle in general, and the emplacement of magma in the crust in particular, involve a number of processes and mechanisms, the interplay between which controls where, when, and how magma can be stored in the crust (e.g. Marsh, 1989). In addition, a series of internal and external parameters influences the type of magma emplacement.

\subsubsection{Parameters controlling magma emplacement}

According to Cruden and McCaffrey (2001), the similarity in dimensions and shapes of intrusions independent from tectonic setting, composition, and age indicate that growth, size, and shape of plutons are controlled by the degree of melting, the mechanism of melt segregation and transport in the lower crust. These factors primarily control the volume of magma available, as well as its spatial and temporal distribution. In analogy, Breitkreuz and Petford (2004) suggest that the interaction between internal and external parameters causes a minimisation of the degree of freedom available for space creation.

The most important internal parameters are probably the compositional and 
physical properties of the magma. Density and viscosity in particular control internal forces of a magma body such as buoyancy (e.g. Roberts, 1970) and magma pressure (Anderson, 1951). According to Hutton (1988), the interplay between these internal forces and the ambient tectonic regime is the reason for the variety of emplacement mechanisms. In fact, magma intrusion and associated volcanism occur in a variety of tectonic settings, e.g. in extensional regimes (Paterson and Fowler, 1993a), such as the mid-oceanic ridges and continental graben systems, as well as in transcurrent (e.g. Tikoff and Teysseir, 1992; Wang et al., 2000; Girard and van Wyk de Vries, 2005) and compressional regimes, such as the cores of large collisional orogens. However, Vigneresse (1995a) demonstrated that independent from the regional stress field, magma emplacement always occurs in locally extensional locations. According to Paterson and Fowler (1993b), regional deformation during pluton emplacement increases local deviatoric stress fields and can thus increase the rate of magma emplacement.

Furthermore, the type of magmaemplacement mechanism varies with depth in the crust (e.g. Read, 1957; Buddington, 1959; Paterson and Fowler, 1993b; Dumond et al., 2005), since the emplacement process itself reflects the interplay between the internal magma forces and the vertical stress as a function of depth (Hogan et al., 1998). In the uppermost kilometres of the crust, magma emplacement reflects the brittle behaviour of crustal rocks (Fyfe, 1970) influenced by the closeness to the free surface (Hutton, 1988). This also emphasises the importance of mechanical and thermal structure of the crust, including factors such as density and viscosity, as a parameter controlling the emplacement of magma (e.g. Bergantz, 1991; Vigneresse, 1995b).

Another parameter that strongly controls the interplay between internal and external controls on magma emplacement is the magma supply rate (cf. Paterson and Tobisch, 1992). Thermodynamical considerations (e.g. Harrison and Clarke, 1979), geophysical surveys of active volcanic regions (e.g. Iyer et al., 1990; Schilling and Partzsch, 2001), as well as studies of the internal structure of numerous plutons (e.g. McNulty et al., 2000; Dumond et al., 2005) suggest that plutons are not emplaced in a single magma pulse, but assemble through incremental accumulation of small magma batches over several million years (e.g. Bachl et al., 2001; Bartley et al., 2005; Clemens, 2005; Coleman et al., 2004; Glazner et al., 2003, 2004; Zak and Paterson, 2005). Consequently, plutonic systems may not represent largely molten magma chambers (Wiebe and Collins, 1998; McNulty et al., 1996; Yoshinubo et al., 1998), which in turn has effects on the efficiency of magma-emplacement mechanisms such as e.g. magmatic stoping or diapirism (see Section 1.2.2.2; Coleman et al., 2004; Zak et al., 2006).

External and internal parameters therefore reflect the existence of spatial 
and temporal gradients of internal pressure, temperature, stress, and strain that drive magma movement (e.g. Ellis and King, 1991) and require a temporal and spatial variation of emplacement mechanisms during the formation of a magma chamber (cf. Buddington, 1959; Spera, 1980; Bergantz, 1991; Furlong et al., 1991).

\subsubsection{Types of emplacement mechanisms}

According to Cloos (1923), the mechanism of magma emplacement is a function of the structural interaction between intruding magma and its host rock. Traditionally, emplacement mechanisms have been subdivided into forceful mechanisms that distort the host rock and passive or permissive mechanisms that take advantage of space $^{2}$ created by regional deformation (e.g. Hutton, 1988). A more recent classification by Paterson and Fowler (1993b) distinguishes between mechanisms that create space, i.e. increase the crustal volume, and material-transfer processes. While the crustal volume can only be increased by surface uplift or by lowering the crust-mantle boundary, most classic magma-emplacement mechanisms can be classified as material-transfer processes.

\footnotetext{
${ }^{2}$ In the context of pluton emplacement, the term "space" is often used for the area into which magma is emplaced, even though it is probably semantically incorrect since there cannot be actual "voids" in the crust. "Space creation" for plutons has been a major point of contention for many years, referred to as "the space problem" (Bowen, 1948; Buddington, 1959).
}

Presently, the following mechanisms of magma emplacement are accepted: (1) diapirism and ballooning, (2) dyke and sill emplacement along fractures, (3) laccolith and lopolith formation, (4) ring faulting and cauldron subsidence, as well as (5) magmatic stoping (e.g. Daly, 1903; Barrel, 1907).

In addition, these emplacement mechanisms can be influenced by the creation of local space in areas of faulting and folding (Paterson and Fowler, 1993a) and, on a more regional scale, by processes such as lateral crustal flow. The relative importance of individual mechanisms varies with depth, distance from the pluton, and time, and is influenced by the parameters discussed above (e.g. Bergantz, 1991; Paterson and Fowler, 1993b). Consequently, the emplacement of magma in the crust is always controlled by a combination of different mechanisms (Buddington, 1959; Paterson and Fowler, 1993b). In the following, a more detailed description of the important mechanisms will be given.

\section{- Diapirism and Ballooning}

According to Paterson and Vernon (1995), diapirism as a magma-emplacement mechanism, can be defined as magma movement into or through the surrounding rock, acting especially in the ductile lower crust. It is therefore a mechanism for magma ascent, driven by magma buoyancy, and balanced by ductile downward flow of the surrounding material (Roberts, 1970). When it reaches the brittle-ductile transition, magma 
ascent by diapirism tends to cease since the buoyancy forces that drive magma movement are not sufficient to fracture the brittle crust (Vigneresse, 1995b). At this stage magma can be emplaced by a mechanism called ballooning that describes the in-situ inflation of a magma chamber during ductile shortening of the country rock (Reesor, 1958; Clifford, 1972; Sylvester et al., 1978; Brun and Pons, 1981; Holder, 1981; Sanderson and Meneilly, 1981; Wikstrom, 1984; Bateman, 1985; Mahood, 1985; Marre, 1986; Castro, 1987; Ramsay, 1989). As reviewed by Paterson and Vernon (1995), the symmetrical, radial expansion of a magma chamber is a result of continuous magma supply through dykes (Shaw, 1980; Bateman, 1984) or from the "tail" of a diapir (Ramberg, 1972; Marsh, 1982; Mahon et al., 1988). Consequently, the crystallising outer part of the magma body and the surrounding hightemperature thermal aureole are deformed by ductile shortening (e.g. Johnson et al., 2001), which can also be supported by ductile downward return flow of the surrounding rock (Paterson and Fowler, 1993b).

Features that are commonly cited as evidence for diapirism and ballooning include the vertical displacement of country rocks (England, 1990); radial structures and rim synclines, as well as denser rocks at the contact with the diapir (Schwerdtner, 1990); an elliptical pluton shape in map view; concentric compositional zoning of the pluton; flattened enclaves near the pluton margin; an increased intensity of the internal foliation towards the margin; narrow, hightemperature shear zones and steep lineations in the aureole; and the deflection of host-rock structures into parallelism with the pluton margin (e.g. Paterson and Vernon, 1995; Clemens et al., 1997). However, some of these features have been discussed controversially since they can occur even without expansion of the rising diapir (cf. Cruden, 1988; Schmeling et al., 1988; Paterson and Vernon, 1995).

Examples of plutons that have been proposed to be at least partly constructed by ballooning include the Chindamora Batholith, Ireland (Ramsay, 1981); the Ardara Pluton, Ireland (Sanderson and Meneilly, 1981); the Joshua Flat-Beer Creek Pluton, California (Dietl, 1999); the Cannibal Creek Pluton, Australia (Bateman, 1985); and the Sausfjellet Pluton, Norway (Dumond et al., 2005).

\section{- The formation of sills, laccoliths, and lopoliths}

Sill emplacement describes the process of concordant magma intrusion between layers by tensile fracturing (Anderson, 1938). The magma-emplacement mechanism of sill formation therefore preferentially occurs within the brittle crust, but has also been discussed as the reason for the layered structure of the lower continental crust. It is generally accepted that sills are fed by dykes that become deflected into a layer-parallel orientation. The basic model of the mechanism of sill emplacement includes that at the level of 
neutral buoyancy (LNB), i.e. the structural level in the crust, where the density of the magma and the surrounding rock are equal, the buoyancy of the magma becomes zero so that magma flow becomes lateral (e.g. Bradley, 1965). Other models explain sill emplacement as a consequence of the rotation of the maximum principal compressive stress $\sigma_{1}$ from a vertical to a horizontal orientation (cf. Roberts, 1970). There are several possible explanations for this stress rotation: (1) where one principal stress is vertical, while the other two are horizontal, and the magnitude of differential stresses is low, sill injection occurs when the magma pressure exceeds the vertical stress during dyke propagation towards the surface (Anderson, 1942; Francis, 1982; Parsons et al., 1992); (2) numerous field examples of sills and laccoliths are emplaced along lithological boundaries (e.g. John, 1988; de Saint-Blanquat et al., 2001, 2006; Valentine and Krogh, 2006), which underlines the importance of mechanical contrasts that can cause local deviations from the regional stress field. As shown in analogue experiments by Kavanagh et al. (2006), a positive rigidity contrast, with an upper more rigid layer, favours sill emplacement; (3) Mudge (1968) and Sylvester et al. (1978) proposed that welldefined parting surfaces such as bedding planes or unconformities are a prerequisite for sill emplacement; this was also confirmed by the results of analogue experiments by Kavanagh et al. (2006).
Once a sill has formed it propagates laterally by tensile fracturing (Anderson, 1938) in the direction of least resistance (Gilbert, 1877). Two resulting endmember geometries can be distinguished: radial symmetrical or saucer-shaped sills and elongate, bilaterally symmetrical sills (Thomson and Hutton, 2004). Geological studies of intrusions in the Henry Mountains, Utah, by Johnson and Pollard (1973) led Pollard and Johnson (1973) to the conclusion that sill thickness is a linear function of its length and that a sill will inflate vertically when its length exceeds a critical value (cf. Gilbert, 1877). Vertical inflation that defines the transition from a sill to a laccolith occurs by a mechanism of bending the overburden as soon as the internal magma pressure can balance the weight of the overlying strata. This implies that laccolith formation is limited to the uppermost kilometres of the crust. At deeper structural levels, floor sinking by ductile downward flow will result in the formation of lopoliths. In both cases, growth of the intrusion results from the successive supply of magma in the form of new sheet- or sill-like units (e.g. Horsman et al., 2005; Morgan et al., 2005; de SaintBlanquat et al., 2006), which are favoured by the creation of a local stress field around the initial intrusion (Vigneresse et al., 1999; Horsman et al., 2005). The dimensional similarity between sills, laccoliths, and large plutons (McCaffrey and Petford, 1997; Cruden and McCaffrey, 2001) suggests that the mechanisms of sill and laccolith emplacement play an 
important role in the emplacement of large plutonic bodies (e.g. Vigneresse, 1999). Examples of intrusions emplaced as sills or laccoliths include the Black Mesa Pluton (de Saint-Blanquat et al., 2006), the Trachyte Mesa Laccolith (Morgan et al., 2005), the Twin Peak Granite (Carrier and Chapman, 1981), and the Maiden Creek Sill, Utah (Johnson and Pollard, 1973; Horsman et al., 2005), the Sonju Lake Layered Intrusion, Minnesota (Maes et al., 2007), the Searchlight Pluton, Nevada (Bachl et al., 2001), the Solsikke Sill Complex, Møre Basin, North Atlantic (Hansen and Cartwright, 2006), the Great Whin and Midland Valley Sills, United Kingdom (Francis, 1982; Goulty, 2005); the Sandfell Laccolith, Iceland (Hawkes and Hawkes, 1933), and the Golden Valley Sill Complex (Galerne et al., 2008) and other intrusions in the Karoo Basin, South Africa (Chevalier and Woodford, 1999).

\section{- Ring faulting, cauldron subsidence, and caldera collapse}

In a study of the geology of Glencoe, Scotland, Clough et al. (1909) described the shape and structural features of the Glencoe Caldera and associated intrusions. Their model for the emplacement of ring dykes and granite plutons at depth and the formation of a collapse caldera at the surface implied the foundering of a central piston of rock bounded by ring dykes. Since then, numerous studies have affirmed a genetic relationship between ring dykes and plutons in so-called ring complexes and calderas (e.g. Anderson,
1936; Myers, 1975; Lipman, 1984; Walker, 1975; Hill, 1991). Ring dykes occupy ring faults; they are shear fractures that form in response to the decrease of pressure in an underlying magma reservoir (Roberts, 1970). Their propagation follows a distinct structural pattern that is known from field studies of eroded calderas (e.g. Lipman, 1984) and equivalent structures (such as e.g. subrosion structures or ice pits; e.g. Branney, 1995), geophysical monitoring of active calderas (e.g. Saunders, 2001), and modelling (e.g. Anderson, 1936; Komuro, 1987; Kusumoto and Takemura, 2003). During magma-chamber deflation, a system of ring faults develops that includes "bell-jar" shaped, outward-dipping reverse faults and inward-dipping normal faults (see reviews by Cole et al., 2005; Acocella, 2007, 2008; Marti et al., 2008). In the field, this array of ring faults can build ring complexes that can form during one or more events of ring faulting. When ring faults reach the surface, a collapse caldera forms and magma, transported through the ring dykes, can be extruded. However, the propagation of the reverse ring faults can also result in the underground detachment of the piston of rock surrounded by the ring fracture. An injection of magma along the ring fault will then cause this central piston to subside, while the created void above the piston fills with magma (Clough et al., 1909; Roberts, 1970) and subsequent ringfaulting is prevented (cf. Branney, 1995). Cauldron subsidence (Clough et al., 1909) thus creates a "bell-jar" intrusion (du Toit, 1920), characterised by subvertical 
to steeply outward-dipping walls and a flat to slightly bell-shaped roof. The compositional layering of many plutons emplaced by cauldron subsidence indicates that the foundering of the central piston occurred incrementally by successive magma injections (e.g. Richey, 1927; Cargill et al., 1928; Stillman, 1970), which tend to fill the pluton from the top down (Cruden and McCaffrey, 2001).

Examples of intrusions emplaced by ring faulting and cauldron subsidence include the Chita Pluton, Argentina (Yoshinubo et al., 2003), the Red Mountain Creek Pluton, California (Zak and Paterson, 2006), plutons in the Coastal Batholith of Peru (Myers, 1975), the Northern Ring Complex of the Nuanetsi Igneous Province, Rhodesia (Stillman, 1970), as well as ring complexes in the Tertiary Igneous Province of Britain such as Mull, Rhum, Ardnamurchan, and Slieve Gullion (e.g. Richey, 1932).

\section{- Magmatic stoping}

The emplacement mechanism of magmatic stoping was originally defined by Daly $(1903,1933)$ as the continued fracturing of wall and roof rocks of a magma body that results in the inclusion and ascent or sinking of the detached blocks. Stoping occurs at any crustal level (Pignotta and Paterson, 2007) as a result of shear or tensile failure (Roberts, 1970), caused by the interplay of e.g. thermal and mechanical stresses associated with dyke emplacement, fluid migration and expulsion, and tectonic stresses (e.g. Daly, 1903; Paterson et al., 2008). Of these parameters, thermal fracturing is the dominant mechanism. Consequently, magmatic stoping is more efficient in the brittle crust mainly due to the large temperature gradients between upper crustal rocks and intruding magma (Zak et al., 2006).

Features that are typically attributed to stoping in a pluton include e.g. (1) stoped blocks; (2) mixed populations of xenoliths; (3) stepped intrusive contacts; (4) the abrupt absence of lithological units or large volumes of material along the contact with the pluton; (5) the lack of penetrative, ductile deformation in the host rock related to pluton emplacement; (6) geochemical evidence for magma contamination (e.g. Paterson and Fowler, 1993b; Fowler and Paterson, 1997; Yoshinubo et al., 2003; Dumond et al., 2005; Glazner and Bartley, 2006; Zak et al., 2006). Even though many of these features are often observed in plutons and other intrusions, the following questions have still not been satisfactorily answered (Clarke et al., 1998) and have to some extent stimulated vigorous debate: (1) By which mechanisms can blocks of host rock become detached from the walls of magma chambers? (2) What is the volumetric significance of stoping for the emplacement of magma bodies? (3) What happens to stoped blocks once detached from the wall or roof of a pluton?

While the basic mechanisms that play a role during stoping are understood on general lines (see above), detailed studies of stoping-related structures are rare. Regarding question 2, a heated debate was 
initiated by Glazner and Bartley (2006) who argued that many of the features commonly attributed to stoping, can be explained by other processes and that stoping is therefore not a volumetrically significant pluton-emplacement process. Their main argument is based on the unclear fate of stoped blocks (question 3) since large accumulations of stoped xenoliths are rarely found in plutons. However, as demonstrated by Clarke et al. (1998), Clarke and Erdmann (2008), and Yoshinubo and Barnes (2008), the processes of the disintegration of xenoliths enclosed within magma, by for instance thermal fracturing and explosive exfoliation (spalling), and subsequent dissolution and melting (McLeod and Sparks, 1998), are very effective and result in contamination of the magma. In addition, stoped blocks can sink rapidly through a magma body, depending on magma viscosity, the density contrast between magma and the xenoliths, and their size, and accumulate on the floor or at other structural levels (e.g. Hawkins and Wiebe, 2004).

Hence, even though the volumetric significance of magmatic stoping has not been conclusively clarified, the mechanism of stoping plays an important role (1) as a vertical material transfer process; (2) because it may remove evidence of earlier emplacement processes (Paterson and Fowler, 1993b; Paterson and Vernon, 1995; Paterson et al., 1991; Yoshinubo et al., 2003); (3) it indicates that large volumes of magma exist in the crust, at any given time, which form large regions of interconnected melt, and thus allowing sinking and removal of stoped blocks; (4) it contributes to chemical contamination of magma and therefore facilitates the compositional evolution of magma (e.g. Dumond et al., 2005; Yoshinubo and Barnes, 2008); (5) it gives insight into the formation and timing of magmatic fabrics (Fowler and Paterson, 1997; Paterson and Miller, 1998); and (6) because discrete stoping events may trigger volcanic eruptions (Hawkins and Wiebe, 2004).

Intrusions that have been assumed to be at least partly emplaced by stoping include dykes in Greenland (Upton, 1974; Bridgwater and Coe, 1970); ring dykes in the Flowers River Igneous Suite, Labrador (Hill, 1991), in Glencoe, Scotland (Clough et al., 1909), and in the Northern Ring Complex of the Nuanetsi Igneous Province, Rhodesia (Stillman, 1970), sills (e.g. Barker, 2000), as well as plutons such as the Chita Pluton, Argentina (Yoshinubo et al., 2003), the Coastal Batholith, Peru (Myers, 1975), the Red Mountain Creek Pluton, California (Zak and Paterson, 2006), the La Gloria Pluton, Chile (Mahood and Cornejo, 1992), the Cerro Aspero Batholith, Argentina (Pinotti et al., 2002), and many of the Variscan Bohemian plutons (Zak et al., 2006).

\subsection{Overview of Chapters 3,4 , and 5}

As shown above, mechanisms of magma emplacement in the upper crust represent material transfer processes mainly controlled by the brittle deformation of the host rock. This includes tensile or 
shear fracturing aided by magma. In this context, the mechanical properties of the host rock such as its elastic properties and internal discontinuities play a major role during initiation of magma emplacement. Chapters 3, 4, and 5 focus on different emplacement mechanisms that play a role in the brittle crust. In this context, dyking is primarily regarded as a transport mechanism of magma that precedes the emplacement of magma bodies controlled by other mechanisms, such as sill emplacement.

Chapter 3 presents the results of a field study of the well-exposed Njardvik Sill, a small basaltic sill in the core of the extinct Dyrfjöll Volcano in Northeast Iceland. The exposure of the Njardvik Sill gives insight into the feeding system, the shape, and mechanical emplacement conditions and therefore allows inferences on its mode of emplacement. The results of the field analysis were used as input parameters for a simple numerical model that examines mechanical aspects of the initiation of the Njardvik Sill. In general, field studies of sills, as well as analogue and numerical models, aim to gain additional insight into questions regarding (1) the feeding rela-tionships between dykes and sills; (2) the reason for stress field rotation at the location where the feeder dyke is deflected into a sill, and in this context, the influence of mechanically-anisotropic host rocks and of interfaces between layers; and (3) the parameters that determine whether a sill develops into a larger magma body.
The kinematics of ring faulting above deflating magma reservoirs is still one of the unanswered questions in volcanology (Acocella, 2007) and a key question to understand the mechanism of cauldron subsidence. Chapter 4 presents the results of a series of scaled analogue experiments that were processed using the technique of Digital Image Correlation. With this technique, it is possible to visualise and quantify the propagation and interaction of ring-fault systems during magmachamber deflation. The sequential evolution of the process of ring faulting observed in the experiments provides insight into the events immediately preceding caldera collapse in the islandarc volcano Miyakejima, Japan, in 2000. This caldera-forming event represents the so-far best-monitored caldera collapse in a basaltic volcano. A better understanding of the kinematics of ring faulting based on analogue modelling therefore provides insight into subvolcanic processes that can lead to magma emplacement in the form of ring dykes and "bell-jar" intrusions, or even culminate in the formation of a collapse caldera at the surface.

Chapter 5 deals with a study of the shallow-crustal Slaufrudalur Pluton in Southeast Iceland with the aim to reconstruct the mechanisms that controlled the emplacement of at least $8 \mathrm{~km}^{3}$ of granitic magma. Excellent exposure conditions allowed the high-precision GPS mapping of the contact between the pluton and its basaltic host rock along several sections. Chapter 5.1 demonstrates the reconstruction of the three-dimen- 
sional shape of the Slaufrudalur Pluton based on the GPS data and discusses to which extent the three-dimensional model provides insight into the magmaemplacement mechanism involved. Chapter 5.2 summarises features of the internal pluton structure, as well as of the contact with the host rock. Based on these observations, the mode of emplacement of the Slaufrudalur Pluton, which includes several mechanisms acting on different scales, namely cauldron subsidence and magmatic stoping, can be inferred. The three-dimensional shape and the plutonwall structures require a modification of the simple cauldron-subsidence mechanism involving regional tectonics that influenced the dynamics of ring faulting and the layering of the host rock. A detailed study of the pluton-roof structures provides further insight into the mechanics of magmatic stoping. Furthermore, the Slaufrudalur Pluton is one of the rare cases where the volumetric contribution of stoping to magma emplacement can be estimated from the shape of the pluton roof.

\subsection{References}

Acocella, V., 2007. Understanding caldera structure and development: An overview of analogue models compared to natural calderas. Earth-Science Reviews 85, 125-160.

Acocella, V., 2008. Structural development of calderas: a synthesis from analogue experiments. In: Gottsmann, J., Marti, J. (eds.), Caldera Volcanism. Analysis, Modelling and Response. Elsevier, Amsterdam, 336 p.

Albarede, F., 1998. The growth of continental crust. Tectonophysics 296, 1-14.
Anderson, E. M., 1936. The dynamics of the formation of cone-sheets, ring-dykes and cauldron subsidences. Proceedings of the Royal Society of Edinburgh 56, 128-157.

Anderson, E. M., 1938. The dynamics of sheet intrusions. Proceedings of the Royal Society of Edinburgh 58, 242-251.

Anderson, E. M., 1942. The Dynamics of Faulting and Dyke Formation with Applications to Britain. Oliver \& Boyd, London.

Anderson, E. M., 1951. The dynamics of faulting. $2^{\text {nd }}$ edition, Oliver \& Boyd, Edinburgh.

Bachl, C. C., Miller, C. F., Miller, J. S., Faulds, J. E., 2001. Construction of a pluton: Evidence from an exposed cross section of the Searchlight pluton, Eldorado Mountains, Nevada. Geological Society of America Bulletin 113, 1213-1228.

Barker, D. S., 2000. Emplacement of a xenolithrich sill, Lajitas, Texas. Journal of Volcanology and Geothermal Research 104, 153-168.

Barrel, J., 1907. Geology of the Marrysville mining district, Montana. A study of igneous intrusion and contact metamorphism. Professional Papers of the United States Geological Survey 57.

Bartley, J. M., Coleman, D. S., Glazner, A. F., 2005. No big tank: Slow incremental growth of plutons by magmatic crack-seal. Geological Society of America Abstract Programs 37, 312.

Bateman, R., 1984. On the role of diapirism in the segregation, ascent and final emplacement of granitoids. Tectonophysics 10, 211-231.

Bateman, R., 1985. Aureole deformation by flattening around a diapir during in situ ballooning: the Cannibal Creek Granite. Journal of Geology 93, 293 -310.

Bergantz, G. W., 1991. Chemical and physical characterisation of plutons. In: Kerrick, D. M. (ed.), Contact Metamorphism. Mineralogical Society of America Reviews in Mineralogy 26, 13-42.

Bowen, N. L., 1948. The granite problem and the method of multiples prejudices. In: Giluly, J., et al. (eds.), Origin of Granite. Geological Society of America Memoirs 28, 79-80. 
Bradley, J., 1965. Intrusion of major dolerite sills. Proceedings of the Royal Society of New Zealand 3, 27-55.

Branney, M. J., 1995. Downsag and extension at calderas: new perspectives on collapse geometries from ice-melt, mining, and volcanic subsidence. Bulletin of Volcanology 57, 303-318.

Breitkreuz, C., Petford, N., 2004. Physical geology of high-level magmatic systems: introduction. In: Breitkreuz, C., Petford, N. (eds.), Physical Geology of High-Level Magmatic Systems. Geological Society of London Special Publications 234, 1-4.

Bridgwater, D., Coe, K., 1970. The role of stoping in the emplacement of the giant dykes of Isortoq, South Greenland. In: Newall, G., Rast, N. (eds.), Mechanism of Igneous Intrusion. Geological Journal Special Issue 2. Gallery Press, Liverpool.

Brun, J. P., Pons, J., 1981. Strain patterns of pluton emplacement in crust undergoing noncoaxial deformation, Sierra Morena, southern Spain. Journal of Structural Geology 3, 219230.

Buddington, A. F., 1959. Granite emplacement with special reference to North America. Geological Society of America Bulletin 70, 671747.

Cargill, H. K., Hawkes, L., Ledeboer, J. A., 1928. The major intrusions of south-eastern Iceland. Quarterly Journal of the Geological Society of London 84, 505-539.

Carrier, D. L., Chapman, D. S., 1981. Gravity and thermal models for the Twin Peaks Silicic volcanic center, southwestern Utah. Journal of Geophysical Research 86, 10287-10302.

Castro, A., 1987. On granitoids emplacement and related structures: A review. Geologische Rundschau 76, 101-124.

Chevalier, L., Woodford, A., 1999. Morph-tectonics and mechanism of emplacement of the dolerite rings and sills of the western Karoo, South Africa. South African Journal of Geology 102, 43-54.

Clarke, D. B., Erdmann, S., 2008. Is stoping a volumetrically significant pluton emplacement process?: Comment. Geological Society of America Bulletin 120, 1072-1074.

Clarke, D. B., Henry, A. S., White, M. A., 1998. Exploding xenoliths and the absence of 'elephants' graveyards' in granite batholiths. Journal of Structural Geology 20, 1325-1343.

Clemens, J. D., 2005. Granites and granitic magmas: strange phenomena and new perspectives on some old problems. Proceedings of the Geological Association 116, 9-16.

Clemens, J. D., Mawer, C. K., 1992. Granitic magma transport by fracture propagation. Tectonophysics 204, 339-360.

Clemens, J. D., Petford, N., Mawer, C. K., 1997. Ascent mechanisms of granitic magmas: causes and consequences. In: Holness, M. B. (ed.), Deformation-enhanced Fluid Transport in the Earth's Crust and Mantle. Chapman \& Hall, London, 144-171.

Clifford, P. M., 1972. Behaviour of an Archean granitic batholith. Canadian Journal of Earth Sciences 9, 71-77.

Cloos, H., 1923. Einführung in die tektonische Behandlung magmatischer Erscheinungen. Teil 1: Das Riesengebirge in Schlesien. Gebrüder Bornträger, Berlin, 194 pp.

Clough, C. T., Brantwood Maufe, H., Battersby Bailey, E., 1909. The cauldron-subsidence of Glen Coe, and the associated igneous phenomena. Quarterly Journal of the Geological Society of London 65, 611-678.

Cole, J. W., Milner, D. M., Spinks, K. D., 2005. Calderas and caldera structures: a review. Earth Science Reviews 69, 1-26.

Coleman, D. S., Gray, W., Glazner, A. F., 2004. Rethinking the emplacement and evolution of zoned plutons: Geochronologic evidence for incremental assembly of the Tuolumne Intrusive Suite, California. Geology 32, 433-436.

Cooper, R. F., 1990. Differential stress-induced melt migration, an experimental approach. Journal of Geophysical Research 95, 6979-6992.

Cruden, A.R., 1988. Deformation around a rising diapir modelled by creeping flow past a sphere. Tectonics 7, 1091-1101.

Cruden, A. E., McCaffrey, K. J. W., 2001. Growth of plutons by floor subsidence: Implications for 
rates of emplacement, intrusion spacing and melt-extraction mechanisms. Physics and Chemistry of the Earth (A) 26, 303-315.

Daines, M. J., 2000. Migration of melt. In: Sigurdsson, H., Houghton, B. F., McNutt, S. R., Rymer, H., Stix, J. (eds.), Encyclopedia of Volcanoes. Academic Press, San Diego, pp. 6988.

Daly, R. A., 1903. The mechanics of igneous intrusion. American Journal of Science 15, 269298.

Daly, R. A., 1933. Igneous rocks and the depth of the earth. McGraw-Hill, New York.

de Saint-Blanquat, M., Law, R. D., Bouchez, J.-L., Morgan, S. S., 2001. Internal structure and emplacement of the Papoose Flat pluton: An integrated structural, petrographic, and magnetic susceptibility study. Geological Society of America Bulletin 113, 976-995.

de Saint-Blanquat, M., Habert, G., Horsman, E., Morgan, S. S., Tikoff, B., Launeau, P., Gleizes, G., 2006. Mechanisms and duration of nontectonically assisted magma emplacement in the upper crust: The Black Mesa pluton, Henry Mountains, Utah. Tectonophysics 428, 1-31.

Dietl, C., 1999. Emplacement of the Joshua FlatBeer Creek Pluton (White Inyo Mountains, California: a story of multiple material transfer processes. In: Castro, A., Fernández, C., Vigneresse, J. L. (eds.), Understanding Granites: Integrating New and Classical Techniques. Geological Society of London Special Publications 168, 161-176.

Dumond, G., Yoshinubo, A. S., Barnes, C. G., 2005, Midcrustal emplacement of the Sjausfjellet pluton, central Norway: Ductile flow, stoping, and in situ assimilation. Geological Society of America Bulletin 117, 383-395.

du Toit, A. L., 1920, The Karoo dolerites of S. Africa: a study in hypabyssal injection: Transactions of the Geological Society of Africa $23,1-42$.

Ellis, M., King, G., 1991. Structural control of flank volcanism in continental rifts. Science $254,839-842$.
England, R. W., 1990. The identification of granite diapirs. Journal of the Geological Society of London 147, 931-933.

Fowler, T. K., Paterson, S. R., 1997. Timing and nature of magmatic fabrics from structural relations around stoped blocks. Journal of Structural Geology 19, 209-224.

Francis, E. H., 1982. Magma and sediment: 1. Emplacement mechanism of late Carboniferous tholeiite sills in northern Britain. Journal of the Geological Society of London 139, 1-20.

Furlong, K. P., Hanson, R. B., Bowers, J. R., 1991. Modeling of thermal regimes. In: Kerrick, D. M. (ed.), Contact Metamorphism. Mineralogical Society of America Reviews in Mineralogy 26, 437-506.

Fyfe, W. S., 1970. Some thoughts on granitic magmas. In: Newall, G. N., Rast, N. (eds). Mechanisms of igneous intrusion. Geological Journal Special Issue 2, 201 - 216.

Fyfe, W. S., 1973. The granulite facies, partial melting and the Archaean crust. Philosophical Transactions of the Royal Society of London 273, 457-461.

Galerne, C. Y., Neumann, E. R., Planke, S., 2008. Emplacement mechanisms of sill complexes: Information from the geochemical architecture of the Golden Valley Sill Complex, South Africa. Journal of Volcanology and Geothermal Research 177, 425-440.

Gilbert, G. K., 1877. Report on the Geology of the Henry Mountains. United States Geographical and Geological Survey of the Rocky Mountains Region, 170 pp.

Girard, G., van Wyk de Vries, B., 2005. The Managua Graben and La Sierras-Masaya volcanic complex (Nicaragua); pull-apart localization by an intrusive complex: results from analogue modeling. Journal of Volcanology and Geothermal Research 144, 3757.

Glazner, A. F., Bartley, J. M., 2006. Is stoping a volumetrically significant pluton emplacement process? Geological Society of America Bulletin 118, 1185-1195.

Glazner, A. F., Bartley, J. M., Coleman, D. S., Lees, J. M., 2003. An iconoclastic view of 
plutons: why big fierce magma chambers are rare. Geological Society of America Abstract Programs 35, 138.

Glazner, A. F., Bartley, J. M., Coleman, D. S., Gray, W., Taylor, R. Z., 2004. Are plutons assembled over millions of years by amalgamation from small magma chambers? GSA Today 14, 4-11.

Goulty, N. R., 2005. Emplacement mechanism of the Great Whin and Midland Valley dolerite sill. Journal of the Geological Society of London 162, 1047-1056.

Hansen, D. M., Cartwright, J., 2006. Saucershaped sill with lobate morphology revealed by 3D seismic data: implications for resolving a shallow-level sill emplacement mechanism. Journal of the Geological Society of London 163, 509-523.

Harrison, T. M., Clarke, G. K. C., 1979. A model of the thermal effects of igneous intrusion and uplift as applied to Quottoon pluton, British Columbia. Canadian Journal of Earth Sciences 16, 411-420.

Hawkes, L., Hawkes, K. H., 1933. The Sandfell laccolith and dome of elevation. Quarterly Journal of the Geological Society of London 89, 379-400.

Hawkins, D. P., Wiebe, R. A., 2004. Discrete stoping events in granite plutons: A signature of eruptions from silicic magma chambers? Geology 32, 1021-1024.

Hawkesworth, C. J., Kemp, A. I. S., 2006. Evolution of the continental crust. Nature 443, 811-816.

Hill, J. D., 1991. Emplacement and tectonic implications of the mid-Proterizoic peralkaline Flowers River Igneous Suite, north-central Labrador. Precambrian Research 49, 217-227.

Hogan, J. P., Price, J. D., Gilbert, M. C., 1998. Magma traps and driving pressure: consequences for pluton shape and emplacement in an extensional regime. Journal of Structural Geology 20, 1155-1168.

Holder, M. T., 1981. Some aspects of intrusion by ballooning: The Ardara pluton. In: Coward, M. P. (ed.), Diapirism and gravity tectonics:
Report of a tectonic studies group. Journal of Structural Geology 3, 89-95.

Horsman, E., Tikoff, B., Morgan, S., 2005. Emplacement-related fabric and multiple sheets in the Maiden Creek sill, Henry Mountains, Utah, USA. Journal of Structural Geology 27, 1426-1444.

Hutton, D. H. W., 1988. Granite emplacement mechanisms and tectonic controls: inferences from deformation studies. Transactions of the Royal Society of Edinburgh: Earth Sciences 79, 245-255.

Iyer, H. M., Evans, J. R., Dawson, P. B., Stauber, D. A., Achauer, U., 1990. Differences in magma storage in different volcanic environments as revealed by seismic tomography: Silicic volcanic centers and subduction-related volcanoes. In: Ryan, M. P. (ed.), Magma Transport and Storage. John Wiley and Sons, Chichester, 293316.

John, B. E., 1988. Structural reconstruction and zonation of a tilted midcrustal magma chamber: the felsic Chemehuevi Mountains Plutonic Suite. Geology 16, 613 - 617.

Johnson, A. M., Pollard, D. D., 1973, Mechanics of growth of some laccolithic intrusions in Henry Mountains, Utah. 1. Field observations, Gilberts model, physical properties and flow of magma. Tectonophysics 18, 261-309.

Johnson, S. E., Albertz, M., Paterson, S. R., 2001. Growth rates of dike-fed plutons: Are they compatible with observations in the middle crust? Geology 29, 727-730.

Jones, S. F., Wielens, H., Williamson, M. C., Zentilli, M., 2007. Impact of magmatism on petroleum systems in the Sverdrup Basin, Canadian Arctic Islands, Nunavut: a numerical modelling study. Journal of Petroleum Geology $30,237-255$.

Jurewicz, A. R., Watson, E. B., 1985. The distribution of partial melt in granitic systems, the application of liquid phase sintering theory. Geochimica et Cosmochimica Acta 49, 11091121.

Kavanagh, J. L., Menand, T., Sparks, R. S. J., 2006. An experimental investigation of sill formation and propagation in layered elastic 
media. Earth and Planetary Science Letters 245, 799-813.

Kemp, A. I. S., Hawkesworth, C. J., 2006. Granitic perspectives in the generation and secular evolution of the continental crust. In: Rudnick, R. L., (ed.), The Crust, Treatise in Geochemistry 3. Elsevier, Amsterdam, 702 pp.

Komuro, H., 1987. Experiments on cauldron formation: a polygonal cauldron and ring fractures. Journal of Volcanology and Geothermal Research 31, 139-149.

Kusumoto, S., Takemura, K., 2003. Numerical simulation of caldera formation due to collapse of a magma chamber. Geophysical Research Letters 30, 2278.

Lipman, P. W., 1984. The roots of ash-flow calderas in western North America: Windows into the tops of granitic batholiths. Journal of Geophysical Research 89, 8801-8841.

Maes, S. M., Tikoff, B., Ferré, E. C., Brown, P. E., Miller Jr., J. D., 2007. The Sonju Lake layered intrusion, northeast Minnesota: Internal structure and emplacement history inferred from magnetic fabrics. Precambrian Research 157, 269-288.

Mahon, K. I., Harrison, T. M. and Drew, D. A., 1988. Ascent of a granitoid diapir in a temperature varying medium. Journal of Geophysical Research 93, 1174 - 1188.

Mahood, G. A., Cornejo, P. C., 1992. Evidence for ascent of differentiated liquids in silicic magma chamber found in a granitic pluton. Transactions of the Royal Society of Edinburgh Earth Sciences 83, 63-69.

Marre, J., 1986. The structural analysis of granitic rocks. Elsevier, Amsterdam, 123 pp.

Marsh, B. D., 1982. On the mechanics of igneous diapirism, stoping and zone melting. American Journal of Science 282, 808 - 855.

Marsh, B. D., 1984. Mechanics and energenics of magma formation and ascension. In: Boyd, F. R. (ed.), Studies in Geophysics: Explosive Volcanism, Inception, Evolution and Hazards. National Academic Press, Washington D.C., 67-83.
Marsh, B. D., 1989. Magma chambers. Annual Review of Earth and Planetary Sciences 17, 439-474.

Marti, J., Geyer, A., Folch, A., Gottsmann, J., 2008. A review on collapse caldera modeling. In: Gottsmann, J., Marti, J. (eds.), Caldera Volcanism, Volume 10 - Analysis, Modelling and Response. Elsevier, Amsterdam, 336 pp.

McCaffrey, K. J. W., Petford, N., 1997. Are granitic intrusions scale invariant? Journal of the Geological Society of London 154, 1-4.

McKenzie, D., 1984. The generation and compaction of partially molten rock. Journal of Petrology 25, 713-765.

McKenzie, D., 1985. The extraction of magma from the crust and mantle. Earth and Planetary Science Letters 74, 81 - 91.

McLeod, P., Sparks, R. S. J., 1998. The dynamics of xenolith assimilation. Contributions to Mineralogy and Petrology 132, 21-33.

McNulty, B. A., Tobisch, O. T., Cruden, A. R., Gilder, S., 2000. Multistage emplacement of the Mount Givens pluton, central Sierra Nevada batholith, California. Geological Society of America Bulletin 112, 119-135.

McNulty, B. A., Tong, W., Tobisch, O. T., 1996. Assembly of a dike-fed magma chamber: The Jackass Lakes pluton, central Sierra Nevada, California. Geological Society of America Bulletin 108, 926-940.

Miller, C. F., Watson, E. B., Harrison, T. M., 1988. Perspectives on the source, segregation and transport of granitoid magmas. Transactions of the Royal Society of Edinburgh Earth Sciences 79, 135-156.

Morgan, S., Horsman, E., Tikoff, B., de SaintBlanquat, M., Habert, G., 2005. Sheet-like emplacement of satellite laccoliths, sills, and bysmaliths of the Henry Mountains, southern Utah. In: Pederson, J., Dehler, C. M. (eds.), Interior Western United States. Geological Society of America Field Guide 6, 283-309.

Mudge, M. R., 1968. Depth control of some concordant intrusions. Geological Society of America Bulletin 79, 315-332.

Myers, J. S., 1975. Cauldron subsidence and fluidization: Mechanisms of intrusion of the 
Coastal Batholith of Peru into its own volcanic ejecta. Geological Society of America Bulletin 86, 1209-1220.

Niemi, A. N., Courtney, T. H., 1983. Settling in solid-liquid systems with specific application to liquid phase sintering. Acta Metallica 9, 13931401.

Parsons, T., Sleep, N. H., Thompson, G. A., 1992. Host rock rheology controls on the emplacement of tabular intrusions: implications for the underplating of extending crust. Tectonics 11, 1348-1356.

Paterson, S. R., Fowler, T. K., 1993a. Extensional pluton-emplacement models: Do they work for large plutonic complexes? Geology 21, 781-784.

Paterson, S. R., Fowler, T. K., 1993b. Reexamining pluton emplacement processes. Journal of Structural Geology 15, 191-206.

Paterson, S. R., Miller, R. B., 1998. Stoped blocks in plutons: paleo-plumb bobs, viscometers, or chronometers? Journal of Structural Geology 20, 1261-1272.

Paterson, S. R., Tobisch, O. T., 1992. Rates of processes in magmatic arcs - Implications for the timing and nature of pluton emplacement and wall rock deformation. Journal of Structural Geology 14, 291-300.

Paterson, S. R., Vernon, R. H., 1995. Bursting the bubble of ballooning plutons: A return to nested diapirs emplaced by multiple processes. Geological Society of America Bulletin 107, 1356-1380.

Paterson, S. R., Vernon, R. H., Fowler, T. K., 1991. Aureole tectonics. In: Kerrick, D. M. (ed.), Contact Metamorphism. Mineralogical Society of America Reviews in Mineralogy 26, 673-722.

Paterson, S. R., Pignotta, G. S., Farris, D., Memeti, V., Miller, R. B., Vernon, R. H., Zák, J., 2008. Is stoping a volumetrically significant pluton emplacement process? Discussion. Geological Society of America Bulletin 120, 1075-1079.

Petford, N., Lister, J. R., Kerr, R. C., 1994. The ascent of felsic magmas in dykes. Lithos 32, 161-168.
Pignotta, G. S., Paterson, S. R., 2007. Voluminous stoping in the Mitchell Peak granodiorite, Sierra Nevada Batholith, California. Canadian Mineralogist 45, 87-106.

Pinotti, L B., Coniglio, J. E., Esparza, A. M., D’Eramo, F. J., Llambias, E. J., 2002. Nearly circular plutons emplaced by stoping at shallow crustal levels, Cerro Aperro batholith, Sierras Pampeanas de Cordoba, Argentina. Journal of South American Earth Sciences 15, 251-265.

Pollard, D. D., Johnson, A. M., 1973. Mechanics of growth of dome laccolithic intrusions in Henry Mountains, Utah. 2. Bending and failure of overburden layers and sill formation. Tectonophysics 18, 311-354.

Ramberg, H., 1972. Theoretical models of density stratification and diapirism in the Earth's crust. Journal of Geophysical Research 77, 877889.

Ramsay, J. G., 1981. Emplacement mechanics of the Chindamara batholith, Zimbabwe. Journal of Structural Geology 3, 93.

Ramsay, J. G., 1989. Emplacement kinematics of a granite diapir: The Chindamora batholith, Zimbabwe. Journal of Structural Geology 11, 191-209.

Read, H. H., 1957. The Granite Controversy. Thomas Murby \& Co, London, 430 pp.

Reesor, J. E., 1958. Dewar Creek map area with special emphasis on the White Creek batholith, British Columbia. Geological Survey of Canada Memoir 292, 78 pp.

Ribe, N. M., 1987. Theory of melt segregation - A review. Journal of Volcanology and Geothermal Research 33, 241-253.

Richey, J. E., 1927. The structural relations of the Mourne Granites, Northern Ireland. Quarterly Journal of the Geological Society of London 83, 653-688.

Richey, J. E., 1932, Tertiary ring structures in Britain: Transactions of the Royal Society of Glasgow 19, 42-140.

Roberts, J. L., 1970. The intrusion of magma into brittle rocks. In: Newall, G., Rast, N. (eds.). Mechanism of Igneous Intrusion. Geological Journal Special Issues 2, 287-338. 
Rubin, A. M., 1993. Dikes vs. diapirs in viscoelastic rochs. Earth and Planetary Science Letters 119, 641-659.

Rudnick, R. B., 1995. Making continental crust. Nature 378, 573-578.

Sanderson, D. J., Meneilly, A. W., 1981. Analysis of three-dimensional strain modified uniform distributions: andalusite fabrics from a granite aureole. Journal of Structural Geology 3, 109116.

Saunders, S. J., 2001. The shallow plumbing system of Rabaul caldera: a partially intruded ring fault? Bulletin of Volcanology 63, 406-420.

Schilling, F. R., Partzsch, G. M., 2001. Quantifying partial melt fraction in the crust beneath the Central Andes and the Tibetan Plateau. Physics and Chemistry of the Earth 26, 239-246.

Schmeling, H., Cruden, A. R., Marquart, G., 1988. Finite deformation in and around a fluid sphere moving through a viscous medium: implications for diapiritic ascent. Tectonophysics 149, 17-34.

Schwerdtner, W. M., 1990. Natural indicators of solid-body rotation in deformed rocks. Tectonophysics 53, T15-T20.

Shaw, H. R., 1980. The fracture mechanism of magma transport from the mantle to the surface. In: Hargraves, R. B. (ed.), Physics of magmatic processes. Princeton University Press, New Jersey, 201-264.

Spera, F. J., 1980. Aspects of magma transport. In: Hargraves, R. B. (ed.), Physics of magmatic processes. Princeton University Press, New Jersey, 263-323.

Stillman, C. J., 1970. Structure and evolution of the Northern Ring Complex, Nuanetsi Igneous Province, Rhodesia. In: Newall, G., Rast, N. (eds.), Mechanism of Igneous Intrusion. Geological Journal Special Issues 2, 33-48.

Svensen, H., Planke, S., Corfu, F., 2008. Sill emplacement and contact metamorphism in the Vøring Basin during formation of the North Atlantic Volcanic Province and the implications for the PETM climate change. International Geological Congress, Oslo, August 6-14 2008, Abstract EUR08204.
Sylvester, A. G., Oertel, G., Nelson, C. A., Christie, J. M., 1978. Papoose Flat pluton: A granitic blister in the Inyo Mountains, California. Geological Society of America Bulletin 89, 1205-1219.

Thomson, K., Hutton, D., 2004. Geometry and growth of sill complexes: insights using 3D seismic from the North Rockall Trough. Bulletin of Volcanology 66, 364-375.

Tikoff, B., Teyssier, C., 1992. Crustal-scale, en echelon 'P-shear' tensional bridges: A possible solution to the batholithic room problem. Geology 20, 927-930.

Upton, B. G. J., 1974. The alkaline province of South West Greenland. In: Sorensen, H. (ed.), The Alkaline Rocks. John Wiley \& Sons, New York, 266 p.

van der Molen, I., Paterson, M. S., 1979. Experimental deformation of partially melted granite. Contributions to Mineralogy and Petrology 70, 299-318.

Valentine, G. A., Krogh, K. E. C., 2006. Emplacement of shallow dikes and sills beneath a small basaltic volcanic center - The role of pre-existing structure (Paiute Ridge, southern Nevada, USA). Earth and Planetary Science Letters 246, 217-230.

Vigneresse, J. L., 1995a. Control of granite emplacement by regional deformation. Tectonophysics 249, 173-186.

Vigneresse, J. L., 1995b. Crustal regime of deformation and ascent of granitic magma. Tectonophysics 249, 187-202.

Vigneresse, J. L., Cuney, M., Barbey, P., 1991. Deformation assisted crustal melt segregation and transfer. Geological Association of Canada - Mineralogical Association of Canada Abstract 16, A128.

Vigneresse, J. L., Tikoff, B., Améglio, L., 1999. Modification of the regional stress field by magma intrusion and formation of tabular granitic plutons. Tectonophysics 302, 203-224.

Walker, G. P. L., 1975. A new concept of the evolution of the British Tertiary intrusive centres. Journal of the Geological Society of London 131, 121-141. 
Wang, T., Wang, X., Li, W., 2000. Evaluation of multiple emplacement mechanisms: the Huichizi granite pluton, Qinling orogenic belt, central China. Journal of Structural Geology $22,505-518$.

Wiebe, R. A., Collins, W. J., 1998. Depositional features and stratigraphic sections in granitic plutons: Implications for the emplacement and crystallization of granitic magma. Journal of Structural Geology 20, 1273-1289.

Wikstrom, A., 1984. A possible relationship between augen gneisses and postorogenic granites in SE Sweden. Journal of Structural Geology 6, 409-415.

Winter, J. D., 2001. An Introduction to Igneous Petrology and Metamorphic Petrology. Prentice Hall, New Jersey, 698 p.

Yoshinubo, A. S., Fowler, T. K., Paterson, S. R., Llambias, E., Tickyi, H., Sato, A. M., 2003. A view from the roof: magmatic stoping in the shallow crust, Chita pluton, Argentina. Journal of Structural Geology 25, 1037-1048.

Yoshinubo, A. S., Barnes, C. G., 2008. Is stoping a volumetrically significant pluton emplacement process? Discussion. Geological Society of America Bulletin 120, 1080-1081.

Yoshinubo, A. S., Okaya, D. A., Paterson, S. R., 1998. Modeling the thermal evolution of fault- controlled magma emplacement models: Implications for the solidification of granitoids plutons. Journal of Structural Geology 20, 1205-1218.

Zak, J. and Paterson, S. R., 2005. Characteristics of internal contacts in the Tuolumne Batholith, central Sierra Nevada, California (USA): Implications for episodic emplacement and physical processes in a continental arc magma chamber. Geological Society of America Bulletin 117, 1242-1255.

Zak, J. and Paterson, S. R., 2006. Roof and walls of the Red Mountain Creek pluton, eastern Sierra Nevada, California (USA): implications for process zones during pluton emplacement. Journal of Structural Geology 28, 575-587.

Zak, J., Holub, F. V., Kachlik, V., 2006. Magmatic stoping as an important emplacement mechanism of Variscan plutons: Evidence from roof pendants in the Central Bohemian plutonic complex (Bohemian Massif). International Journal of Earth Sciences 95, 771-789. 


\subsection{Active tectonics in Iceland}

2.1.1 Mantle plume - Mid-ocean ridge interaction

Iceland is located in the central North Atlantic and represents the subaerial part of the Mid-Atlantic Ridge between the ridge segments Reykjanes Ridge in the south and Kolbeinsey Ridge in the north, which separate the European from the North American Plate. Spreading velocities across Iceland have been estimated at 18.3 $\mathrm{mm} \mathrm{a} \mathrm{a}^{-1}$ over the last $3 \mathrm{Ma}$ in the direction of $105^{\circ}$ (E; NUVEL-1A model of global plate motion; DeMets et al., 1990).

Iceland's existence above sea level is a consequence of the interaction of the MidAtlantic Ridge with the Iceland Mantle Plume (Morgan, 1971). The Iceland Mantle Plume became active during late Senonian (80 Ma) and has influenced the North Atlantic region throughout the opening of the North Atlantic. Extensive magma production caused by the plume head $\left(\sim 10^{7}\right.$ $\mathrm{km}^{3}$ in 2-3 Ma; e.g. White et al., 1987; White and McKenzie, 1989) has led to the formation of flood basalts and volcanic centres in Greenland, the Faeroe Islands, and the British Isles. Currently the plume centre is estimated to lie beneath southern central Iceland, where it, in combination with the Mid-Atlantic Ridge, causes a maximum of $20 \%$ partial melting above a depth of around $100 \mathrm{~km}$ (e.g. White and McKenzie, 1995). More than $99.9 \%$ of the magma volume primarily produced by the interaction of the Iceland Mantle Plume and the Mid-Atlantic Ridge is basaltic with a geochemical signature that clearly reveals an origin by mixing of MORB and OIB sources (Oskarsson et al., 1985; Sigmarsson and Steinthrosson, 2007; Sigmarsson et al., 2008). Another effect of the influence of the Iceland Mantle Plume is a pronounced offset of the axial rift zones in Iceland relative to the Reykjanes and Kolbeinsey Ridge (Saemundsson, 1979).

\subsubsection{Crustal structure}

As a consequence of the high melt production associated with the Iceland Mantle Plume, the crust in the area of Iceland is characterised by an anomalously high thickness of $15 \mathrm{~km}$ below coastal regions and up to $46 \mathrm{~km}$ below central Iceland (Allen et al., 2002). Based on seismic wave speeds (e.g. Staples et al., 1997; Menke et al., 1998; Weir et al., 2001 Bjarnason et al., 2002), the crust below Iceland consists of an upper crust with a thickness of 0.7 to $3.0 \mathrm{~km}$ composed of basaltic lava flows that become more altered with depth, the mid-crust with a thickness of 2.0 to $4.5 \mathrm{~km}$, and the lower crust with a thickness of 14 to $20 \mathrm{~km}$. The boundaries between the crustal levels depend on the state of alteration and the proportion of intrusions (Flovenz and Gunnarsson, 1991). 


\subsubsection{Structure of the rift zone}

The plate boundary in Iceland is divided into volcanic rift zones and flank zones(Fig. 2.1; Saemundsson, 1979). Flank zones exhibit little or no crustal spreading and are characterised by the production of alkali olivine basalts and transitional alkali basalts (Jakobsson, 1972, 1979a, b).
Zone, and the Öraefajökull-Snaefell Flank Zone in East Iceland. In contrast, rift zones are charac-terised by extensive crustal spreading and the production of tholeiites. In South-west Iceland, the ReykjanesLangjökull Volcanic Zone has been active for at least 6 to $7 \mathrm{Ma}$ (Saemundson, 1979, 1986). It can be sub-divided into the

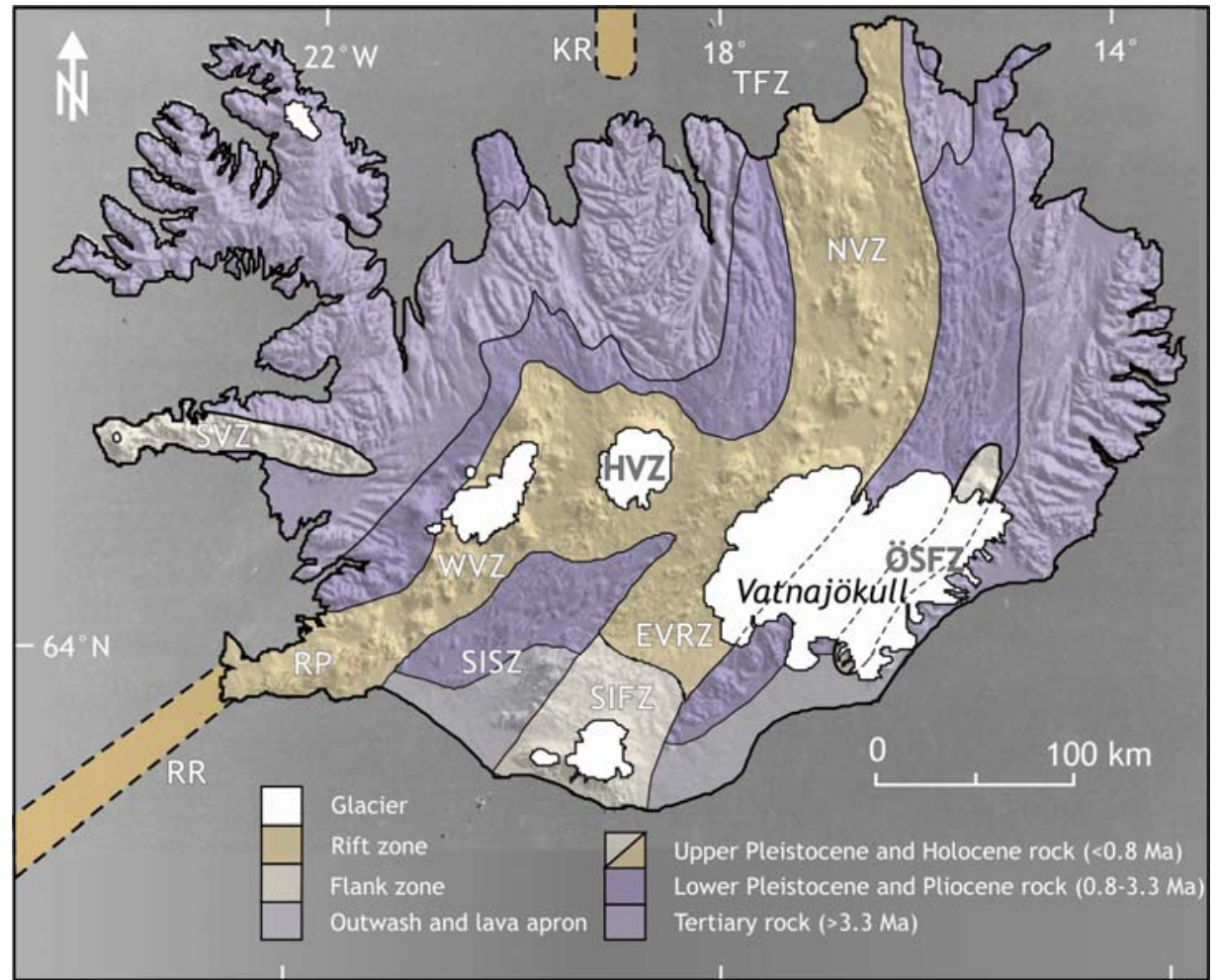

Figure 2.1. Geological map of Iceland with volcanic zones. Background image shows topographic relief according to the Digital Elevation Model provided by the National Land Survey of Iceland. The main structures controlling the tectonics of the Iceland plateau are the Mid-Atlantic Ridge segments RR (Reykjanes Ridge) and KR (Kolbeinsey Ridge), the transform zones TFZ (Tjörnes Fracture Zone) and SISZ (South Iceland Seismic Zone), the rift zones RP (Reykjanes Peninsula), WVZ (West Volcanic Zone), HVZ (Hofsjökull Volcanic Zone), NVZ (North Volcanic Zone), and EVRZ (East Volcanic Rift Zone), as well as the flank zones SVZ (Snaefellsnes Volcanic Zone), SIFZ (South Iceland Flank Zone), and ÖSFZ (Öraefajökull-Snaefell Flank Zone).
Reykjanes Peninsula Oblique Rift and the West Volcanic Zone (Einarsson, 1991). In the east of Iceland, the rift zone can be divided into the North Volcanic Zone north of Vatnajökull and the East Volcanic Zone south of Vatnajökull (e.g. Oskarsson et al., 1985; Einarsson, 1991). The North Volcanic Zone has been active for the last 6 to 7 Ma (Einarsson, 1991), whereas the East Volcanic Zone has an age of 2 to 3 $\mathrm{Ma}$ and is currently propagating southwards (Johannesson, 1980). The East Volcanic Zone can furthermore be subdivided into the East
There are three flank zones - the Snaefellsness Volcanic Zone in West Iceland, the South Iceland Volcanic Flank
Volcanic Rift Zone north of the South Iceland Seismic Zone and the South Iceland Flank Zone, which differ in 
deformation style and petrology of the products. In Central Iceland, the part of the rift zone around Mt. Hofsjökull is either defined as part of the West Volcanic Zone or as the separate Middle Iceland Volcanic Zone (e.g. Oskarsson et al., 1985) or Hofsjökull Volcanic Zone.

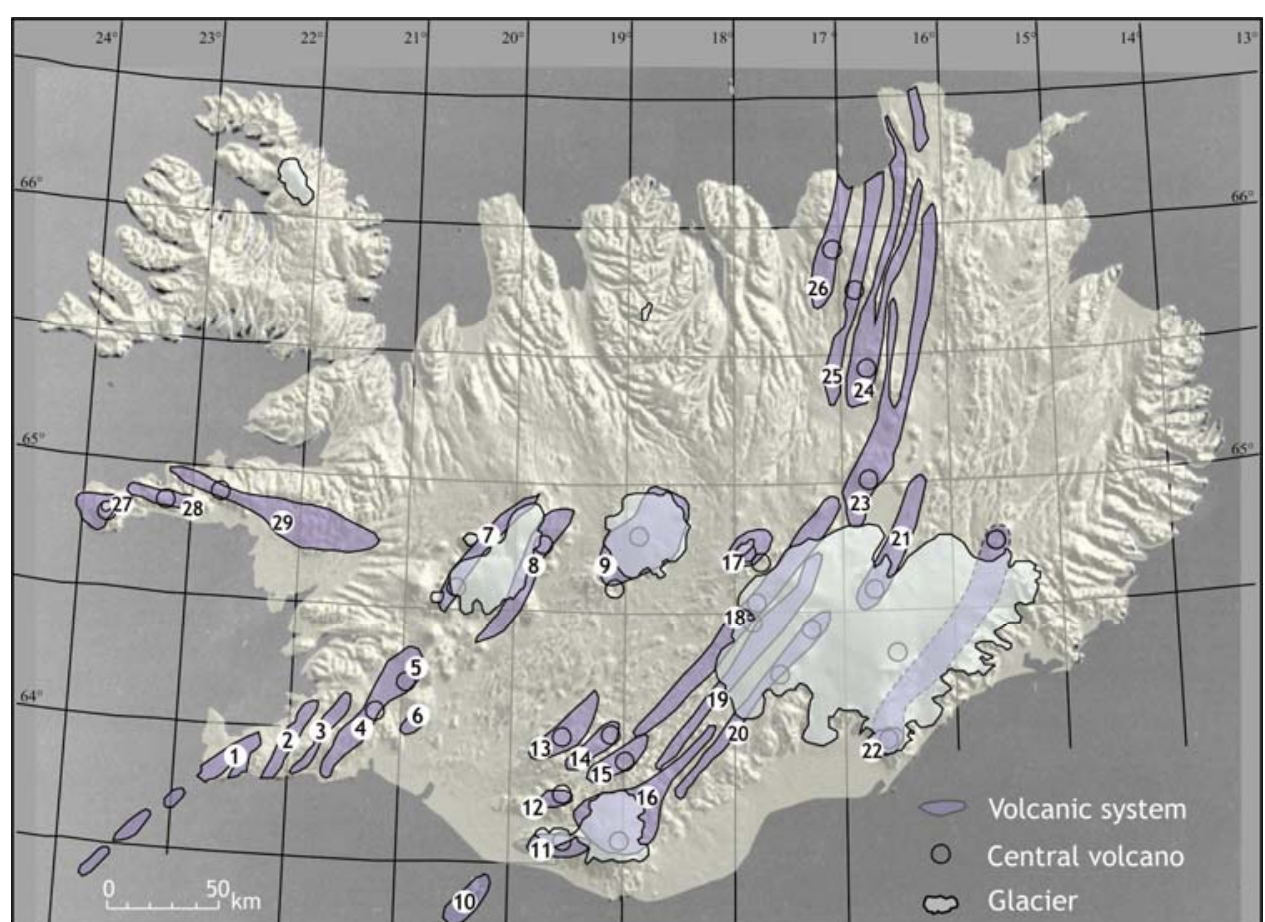

The volcanic zones include an array of volcanic systems that were first defined by Saemundsson (1979; Fig. 2.2). In 1987, Einarsson and Saemundsson distinguished more than 30 volcanic systems. At the surface, each volcanic system consists of an elongated fissure swarm composed of tension fractures, normal faults, and eruptive fissures. In addition, most volcanic systems include a central volcano, the focus of volcanic activity, characterised by the occurrence of felsic volcanic rocks, hightemperature geothermal fields, and, eventually, a collapse caldera.
Figure 2.2. Active volcanic systems and central volcanoes of Iceland according to Einarsson and Saemundsson (1987). Background image shows topographic relief according to the Digital Elevation Model provided by the National Land Survey of Iceland. 1 Reykjanes, 2 - Krisuvik, 3 - Brennisteinsfjöll, 4-Hengill, 5 - Kálftindar, 6-Grimsnes, 7 Prestahnjukur, 8 - Langjökull, 9 - Hofsjökull, 10 - Vestmannaeyjar, 11 - Eyjafjallajökull, 12 - Tindföll, 13 - Hekla, 14 - Vatnafjöll, 15 Torfajökull, 16 - Katla, 17- Tungnafellsjökull, 18 - Bárdarbunga, 19 - Fögrufjöll, 20 Grimsvötn, 21 - Kverkfjöll, 22 - ÖraefajökullSnaefell, 23 - Askja, 24 - Fremri Námar, 25 Krafla, 26 - Theistareykir, 27 - Snaefellsnes, 28 - Lysuskard, and 29-Ljosufjöll.

\subsubsection{Temporal evolution of the rift zone}

2.1.4.1 Stratigraphic classification of Iceland

The stratigraphic classification of Iceland is based on absolute age data, as well as on the changes of climatic and palaeomagnetic conditions with time. The oldest exposed rocks have an age of around 14 to $15 \mathrm{Ma}$ and are exposed in the West Fjords, in the north, and in the east of the country. An overview of the stratigraphic classification is given by Saemundsson (1979), Einarsson (1991), and Tordarson and Hoskuldsson (2002).

The oldest stratigraphic unit of Iceland is the Tertiary, which includes all rocks older 
than 3.3 Ma. It mainly consists of a pile of 5 to $15 \mathrm{~m}$ thick subaerial lava flows separated by minor clastic interbeds of volcaniclastic or sedimentary origin (Saemundsson, 1979). The thickness of the Tertiary lava pile in East Iceland is between 10 (Walker, 1974) and $12 \mathrm{~km}$ (Torfason, 1979). It is characterised by a tilt of the lava flows towards the active rift zone with an increase in dip with depth (Saemundsson, 1979; see Section 2.2.1). Tertiary volcanic centres are distributed within the lava pile (see Section 2.2.2).

The Tertiary is followed by the so-called Plio-Pleistocene that extends from the Pliocene to the Lower Pleistocene and includes a time range from 3.3 to $0.8 \mathrm{Ma}$. The rocks of the Plio-Pleistocene conformably overlie the Tertiary lava pile, except in some locations in western Iceland. The occurrence of fluvioglacial deposits, hyaloclastites, pillow lavas and breccias, in addition to subaerial lava flows, indicate that during the PlioPleistocene, cold periods alternated with warm periods. According to Saemundsson and Noll (1974), glaciations occurred every 100 to $120 \mathrm{ka}$.

The Upper Pleistocene encompasses the time between $0.8 \mathrm{Ma}$ and the Postglacial. It is characterised by more extensive glaciations. However, the accumulation of volcanic rocks dominated over glacial and fluvial erosion. Nevertheless, deep fjords were carved out in the coastal areas.

The Postglacial period began around 11.5 ka BP with the deglaciation of the coastal regions. Postglacial deposits include subaerial lava flows and pyroclastic rocks, as well as fluvial sediments and soils. The intensity of volcanic activity during the Postglacial was variable, with higher production rates immediately after deglaciation (e.g. Hardarson and Fitton, 1991), which can be related to extensive mantle melting caused by unloading (Maclennan et al., 2002).

\subsubsection{Rift jumps}

Even though it was previously believed that active volcanoes drift away from the rift zone and become inactive so that crustal accretion is locally fixed (Bödvarsson and Walker, 1964; Palmason, 1981), it is now understood that the active volcanic rift zone is subject to reconfiguration over time. This is a consequence of the overall westward movement of the plate boundary between North American and Eurasian Plate relative to the Iceland Mantle Plume. Riftzone relocations (rift jumps) in the past are evident from the location of monoclines created by the tilt of the lava pile towards the active rift zone (Johannesson, 1980). The overall pattern of rift jumps was outlined by Johannesson (1980). Evidence for the oldest known rift zone (older than $14.9 \mathrm{Ma}$ ) has been found in the West Fjords (Hardarson et al., 1997). This rift zone was followed by the Snaefellsnes-Skagi Rift Zone that was directly connected to the Reykjanes Ridge and was active from 15 to $7 \mathrm{Ma}$. Activity then shifted to the presently-active Reykjanes-Langjökull Volcanic Zone. The transition of activity of one rift zone to the next is characterised by a temporal overlap, similar to the present 
shift from the Reykjanes-Langjökull Volcanic Zone to the East Volcanic Zone (see Section 2.1.3). Models explaining the mechanism of rift jumps were developed by e.g. Gibson and Piper (1972) and Helgason (1984). Gibson and Piper (1972) proposed that after a given time, the fissure swarm and the associated package of lava flows drift laterally away and a new swarm develops to the east or west of the long-term deformation strip. From an analysis of the distribution of volcanic centres in the Tertiary lava pile of eastern Iceland (see Section 2.2.2), Helgason (1984) concluded that rift jumps occur frequently on different scales: smallscale jumps with a distance of 20 to 40 $\mathrm{km}$ to the east or west occur approximately every $2 \mathrm{Ma}$, whereas large-scale rift jumps with a distance of 100 to $200 \mathrm{~km}$ can occur every 6 to $7 \mathrm{Ma}$.

As a consequence of rift jumps, extinct volcanic centres of different ages in the Tertiary and PlioPleistocene part of Iceland have not line- arly drifted away from the rift zone, but are distributed in a pattern, which is a function of the direction of rift jumps. In addition, activity can also shift back to the area of an extinct rift zone, so that new rift segments can form in older crust with a higher proportion of evolved rocks.

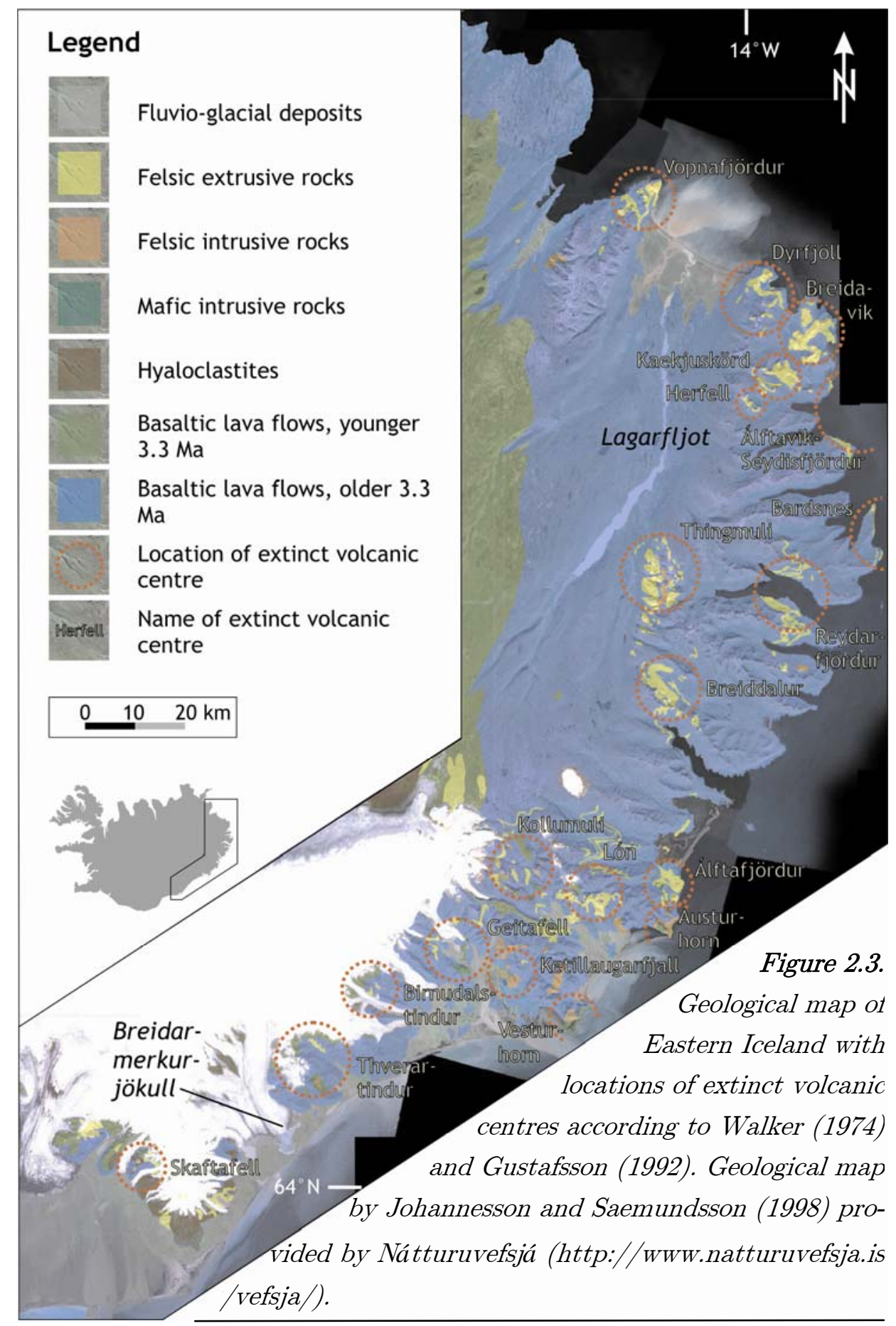


2.2 Structure of Tertiary rift zones in East Iceland

East Iceland is characterised by the exposure of a Tertiary lava pile with a cumulative thickness of 10 (Walker, 1974) to $12 \mathrm{~km}$ (Torfason, 1979), exposed in mountainous terrain dissected by deep fjords. Within the lava pile, fossil volcanic structures are embedded (Fig. 2.3). East Iceland therefore offers a view into the deep structure of the Tertiary crust. from three different methods (Fig. 2.4). In general, the dip of the lava pile is uniform towards the active rift zone in the west. However, the dip angle decreases regularly from 6 to $9^{\circ}$ at or near sea level, to $2^{\circ}$ at an altitude of 700 to $900 \mathrm{~m}$. This change in dip is thought to be a result of loading of the lava pile by addition of material in the active rift zone (Walker, 1974; Saemundsson, 1979). According to Walker (1974), the extrapolated altitude of zero

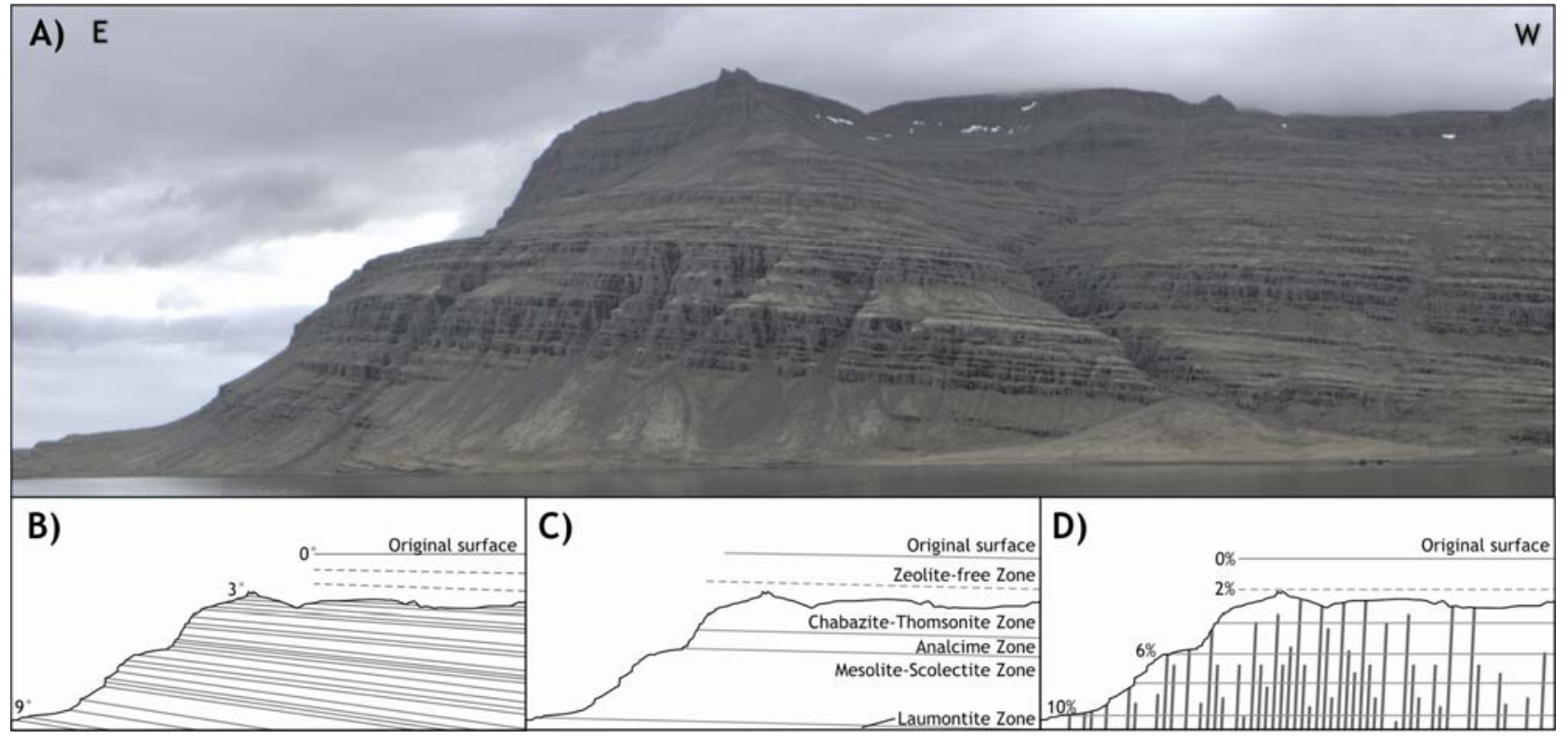

Figure 2.4. A) The Tertiary lava pile on the southern shore of Berufjördur near Djupivogur in Southeast Iceland. B)-D) Schematic sketches illustrating methods to determine the level of erosion in Eastern Iceland (based on Walker, 1960; 1974): B) extrapolation of the level of zero dip of the lava; C) zeolite zones; D) extrapolation of the level of zero intrusion density.

\subsubsection{Determination of the level of erosion}

In order to define the crustal depth of structures exposed in East Iceland, the level of erosion has to be known. According to Walker $(1960,1974)$, it can be inferred dip corresponds to the original top of the lava pile (Fig. 2.4B). A second method is based on the mapping of regional metamorphic zones of zeolites in amygdales within the Tertiary basalt lavas. Within the lava pile, zeolites are distributed in nearly horizontal zones, parallel to each other. Walker $(1960,1974)$ proposed that these zones represent fossil geothermal isotherms parallel to the original surface of the Tertiary lava pile. From the distribution of the zeolite zones, the altitude of the original surface can be estimated to be around $600 \mathrm{~m}$ above the analcime zone (Fig. 2.4C; Walker, 1960). 
In addition, the level of erosion can be determined from dyke frequency or the dilation due to dyke intrusion (Fig. 2.4D). Based on the observation that the dyke intensity decreases with altitude, Walker (1960, 1974) proposed that the extrapolated altitude of zero intensity is believed to approximate the original top of the crust. Since the three methods give consistent results with a maximum deviation of $200 \mathrm{~m}$, the level of erosion at sea level ranges from around $2000 \mathrm{~m}$ in Southeast Iceland (Walker, 1974) to around $1100 \mathrm{~m}$ in Northeast Iceland (Gustafsson, 1992).

\subsubsection{Structure of East Iceland: Extinct} volcanic systems

The overall structure of East Iceland is characterised by the uniform dip of the Tertiary lava pile towards the west (Fig. 2.2). Superimposed on this structure, the Lagarfljot Flexure Zone represents a broad monocline with anomalously high dips of around $10^{\circ}$ towards the west between Breidarmerkurjökull in the south and the Lagarfljot Valley in the north (Torfason, 1979).

Deep glacial erosion has carved sections through extinct, Tertiary volcanic systems embedded within the lava pile (Fig. 2.3). They are characterised by the following features: (1) the occurrence of felsic volcanic and plutonic rocks that are restricted in Iceland to volcanic centres (Walker, 1966); (2) anomalous dips of lava flows as a consequence of deflation of the centre of a volcano (Walker, 1964) or deposition on its flanks (Walker, 1963); (3) plutonic bodies composed of gabbro or granite/granodiorite (e.g. Austurhorn, Vesturhorn, Slaufrudalur; see Chapter 5); (4) swarms of intrusive sheets (Walker, 1974); (5) a disturbance of the regional metamorphic zones (see Section 2.2.1; Fig. $2.4 \mathrm{C}$ ) and the local occurrence of propylite and carbonate zones delineating fossil hightemperature geothermal fields (Walker, 1974; Fridleifsson, 1983a, 1983b, 1984); and (6) swarms of subvertical dykes (Walker, 1974). These features are the depth equivalents of the structures observed at the surface in the active rift zone (see Section 2.1.3). Together, they give a three dimensional image of a volcanic system as illustrated in Fig. 2.5.

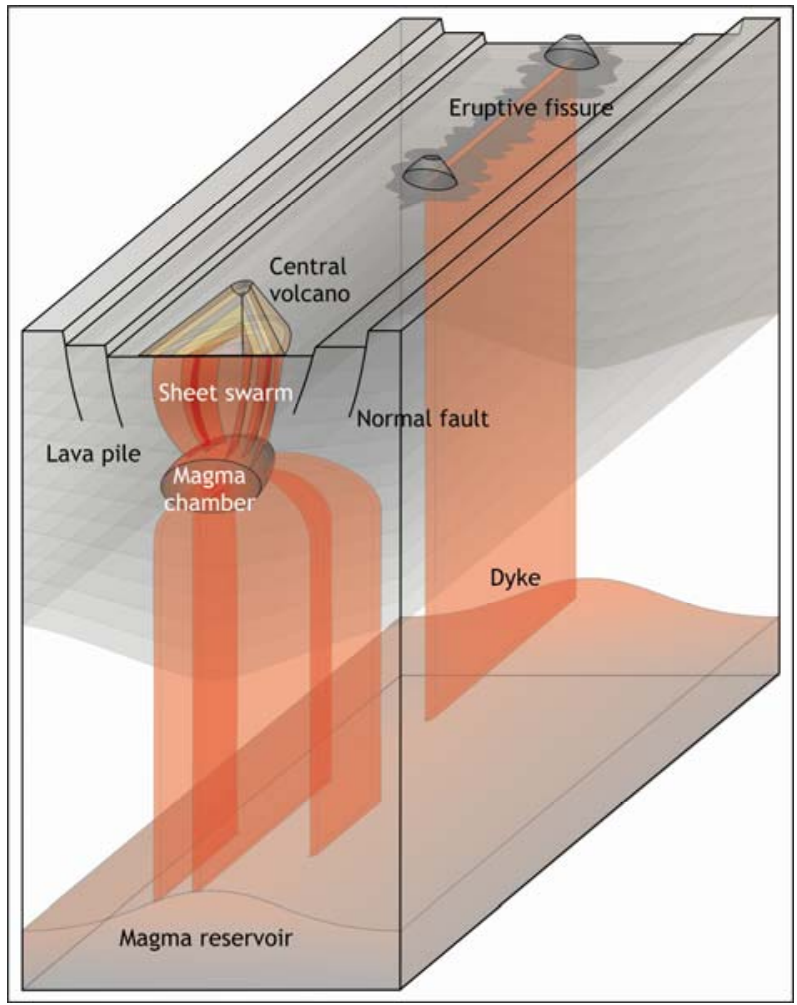

Figure 2.5. Schematic sketch of the structural inventory of a volcanic system according to Saemundsson (1979; surface) and Walker (1966; depth). Modified from Burchardt and Gudmundsson (2009). 
In accordance with this model, dyke swarms correspond to eruptive fissures at the surface. Plutons represent the cores of central volcanoes that are associated with sheet swarms and surrounded by geothermal circulation systems. According to Walker (1966), volcanic centres develop when the magmatic activity becomes focussed due to the formation of an intracrustal reservoir beneath each centre, and the resulting point of weakness causes a localisation of subsequently-injected dykes to a narrow zone passing through it. Interestingly, Walker (1966) notes that the initiation of the intra-crustal reservoir might be "a fortuitous circumstance".

Examples of Tertiary volcanic centres in East Iceland include Breidalur (Walker, 1963), Thingmuli (Carmichael, 1964, 1967), Kollumuli (Torfason, 1979), Geitafell (Annels, 1967; Newman, 1967; Fridleifsson, 1983a; Burchardt and Gudmundsson, 2009), and Dyrfjöll (Gustafsson, 1992). The distribution of volcanic systems in East Iceland indicates that there is no linear correlation between age and distance of an individual centre from the rift zone. This led Helgason (1984) to the conclusion that contemporaneous volcanic centres that delineate the Tertiary rift zone at the time of their activity outline at least three different volcanic zones (see Section 2.1.4) which were active between 12.5 and $8 \mathrm{Ma}$ in the area between Thingmuli and Alftafjördur. Younger volcanic systems to the south may therefore have formed in an even younger rift zone.

\subsection{Significance for this study}

The Tertiary of East Iceland represents a fossil analogue for the active rift zones of Iceland. Glacial erosion has provided insight into the deep structure of the Tertiary lava pile and associated volcanic systems down to a depth of around $2 \mathrm{~km}$ below the original surface. The exposed magmatic structures therefore represent ideal objects to study the mechanisms controlling their emplacement at this depth. Hence, East Iceland is an ideal area to study magma-emplacement mechanisms in the brittle crust in a rift environment.

\subsection{References}

Allen, R. M., Nolet, G., Morgan, W. J., Vogfjörd, K., Nettles, M., Ekström, G., Bergsson, B. H., Erlendsson, P., Foulger, G. R., Jakobsdottir, S. et al., 2002. Plume-driven plumbing and crustal formation in Iceland. Journal of Geophysical Research 107, doi:10.1029/2001JB000584.

Annels, A. E., 1967. Geology of the Hornafjördur region, S. E. Iceland. Ph.D. Thesis, University of London, 278 pp.

Bjarnason, I. T., Silver, P. G., Rümpker, Solomon, S. C., 2002. Shear wave splitting across the Iceland hot spot: Results from the ICEMELT experiment. Journal of Geophysical Research 107, doi:10.1029/2001JB000916.

Bödvarsson, G., Walker, G. P. L., 1964. Crustal drift in Iceland. Geophysical Journal 8, 285-300.

Burchardt, S., Gudmundsson, A., 2009. The infrastructure of Geitafell Volcano, Southeast Iceland. In: Thordarson, T., Larsen, G., Self, S., Rowland, S., Hoskuldsson, A. (eds.). Studies in Volcanology: The Legacy of George Walker. Geological Society of London, Special Publications, in press. 
Carmichael, I. S. E., 1964. The petrology of Thingmuli, a Tertiary volcano in Eastern Iceland. Journal of Petrology 5, 435-460.

Carmichael, I. S. E., 1967. The mineralogy of Thingmuli, a Tertiary volcano in Eastern Iceland. American Mineralogist 52, 1815-1841.

DeMets, C., Gordon, R. G., Argus, D. F., Stein, S., 1990. Current plate motions. Geophysical Journal International 101, 425-478.

Einarsson, T., 1991. Myndun og mótun lands. Mál of Menning, Reykjavik.

Einarsson, P., Saemundsson, K., 1987. Earthquake epicentres 1982-1985 and volcanic systems in Iceland. In: Sigfusson, T. (ed.), I hlutarins edli: Festschrift for Thorbjorn Sigurgeirsson, Menningarsjodur, Reykjavik [Map].

Flovenz, O. G., Gunnarsson, K., 1991. Seismic crustal structure in Iceland and surrounding area. Tectonophysics 189, 1-17.

Fridleifsson, G. O., 1983a. The geology and the alteration history of the Geitafell central volcano, Southeast Iceland. Ph.D. Thesis, Grant Institute of Geology, University of Edinburgh, $371 \mathrm{pp}$.

Fridleifsson, G. O., 1983b. Mineralogical evolution of a hydrothermal system. GRC-Transactions 7, 147-152.

Fridleifsson, G. O., 1984. Mineralogical evolution of a hydrothermal system II. Heat sources - fluid interactions. GRC-Transactions 8, 5 pp.

Gibson, I. L., Piper, J. D. A., 1972. Structure of the Icelandic basalt plateau and the process of drift. Philosophical Transactions of the Royal Society of London, Series A 271, 141-150.

Gustafsson, L. E., 1992. Geology and Petrography of the Dyrfjöll Central Volcano, Eastern Iceland. Berliner Geowissenschaftliche Abhandlungen Reihe A, Band 138, 103 pp.

Hardarson, B. S., Fitton, J. G., 1991. Increased mantle melting beneath Snaefellsjökull volcano during late Pleistocene deglaciation. Nature 353, 62-64.

Hardarson, B. S., Fitton, J. G., Ellam, R. M., Pringle, M. S., 1997. Rift relocations: A geochemical and geochronological investigation of a palaeo-rift in northwest Iceland. Earth and Planetary Science Letters 153, 181-196.
Helgason, J., 1984. Frequent shifts of the volcanic zone in Iceland. Geology 12, 212-216.

Jakobsson, S. P., 1972. Chemistry and distribution pattern of basaltic rocks in Iceland. Lithos 5, 365-386.

Jakobsson, S. P., 1979a. Petrology of recent basalts of the Eastern Volcanic Zone, Iceland. Acta Naturalia Islandica 26, 1-103.

Jakobsson, S. P., 1979b. Outline of the petrology of Iceland. Jökull 29, 57-73.

Johannesson, H., 1980. Evolution of rift zones in western Iceland. Natturufraedingurinn 50, 13-31 [in Icelandic with English summary].

Johannesson, H., Saemundsson, K., 1998. Geological Map of Iceland, 1: 500 000, Bedrock Geology (2nd Edition). Icelandic Institute of Natural History, Reykjavik [Map].

Maclennan, J., Jull, M., McKenzie, D., Slater, L., Grönvold, K., 2002. Link between volcanism and deglaciation in Iceland. $\mathrm{G}^{3}-$ Geochemistry Geophysics Geosystems 3, doi: 10.1029/2001G C000282.

Menke, W., West, M., Brandsdottir, P., Sparks, D., 1998. Compressional and shear velocity structure of the lithosphere in Northern Iceland. Bulletin of the Seismic Society of America 88, 1561-1571.

Newman, T. C., 1967. The Geology of some Igneous Intrusions in the Hornafjördur Region of S. E. Iceland. Ph.D. Thesis, University of Manchester, $168 \mathrm{pp}$.

Oskarsson, N., Steinthorsson, S., Sigvaldason, G. E., 1985. Iceland geochemical anomaly: Origin, volcanotectonics, chemical fractionation and isotope evolution of the crust. Journal of Geophysical Research 90, 10011-10025.

Palmason, G., 1981. Crustal rifting, and related thermo-mechanical processes in the lithosphere beneath Iceland. Geologische Rundschau 70, 244-260.

Saemundsson, K., 1979. Outline of the geology of Iceland. Jökull 29, 7-28.

Saemundsson, K., 1986. Subaerial volcanism in the western North Atlantic. In: Vogt, P. R., Tucholke, B. E. (eds.), The Geology of North America. Volume M: The Western North Atlantic Region. Geological Society of America, Colorado, pp. 69-86. 
Saemundsson, K., Noll, H., 1974. K/Ar ages of rocks from Husafell, Western Iceland, and the development of the Husafell central volcano. Jökull 24, 40-59.

Sigmarsson, O., Steinthorsson, S., 2007. Origin of Icelandic basalts: A review of their petrology and geochemistry. Journal of Geodynamics 43, 87-100.

Sigmarsson, O., Maclennan, J., Carpentier, M., 2008. Geochemistry of igneous rocks in Iceland: a review. Jökull 58, 1-21.

Staples, R. K., White, R. S., Brandsdottir, B., Menke, W., Maguire, P. K. H., McBride, J. H., 1997. Faeroe-Iceland ridge experiment, 1: Crustal structure of northeastern Iceland. Journal of Geophysical Research 102, 7849-7866.

Thordarson, T., Hoskuldsson, A., 2002. Iceland: Classic Geology in Europe (Volume 3). Terra, United Kingdom, 200 pp.

Torfason, H., 1979. Investigations into the structure of south-eastern Iceland. Ph.D. Thesis, University of Liverpool, Liverpool, 589 pp.

Walker, G. P. L., 1960. Zeolite zones and dyke distribution in relation to the structure of the basalts in Eastern Iceland. Journal of Geology 68, 515-528.

Walker, G. P. L., 1963. The Breiddalur Central Volcano, Eastern Iceland. Quarterly Journal of the Geological Society of London 118, 275-293.
Walker, G. P. L., 1964. Geological investigations in Eastern Iceland. Bulletin of Volcanology 27, 351363.

Walker, G. P. L., 1966. Acid volcanic rocks in Iceland. Bulletin of Volcanology 29, 375-402.

Walker, G. P. L., 1974. The structure of eastern Iceland. In: Kristiansson, L. (ed.), Geodynamics of Iceland and the North Atlantic Area. Dordrecht, Reidel, p. 177-188.

Weir, N. R. W., White, R. S., Brandsdottir, B., Einarsson, P., Shimamura, H., Shiobara, H., 2001. Crustal structure of the northern Reykjanes ridge and the Reykjanes Peninsula, southwest Iceland. Journal of Geophysical Research 106, 6247-6368.

White, R. S., McKenzie, D., 1989. Magmatism at rifted zones: the generation of volcanic continental margins and flood basalts. Journal of Geophysical Research 94, 7685-7729.

White, R. S., McKenzie, D., 1995. Mantle plumes and flood basalts. Journal of Geophysical Research 100, 17543-17585.

White, R. S., Spence, G. S., Fowler, S. R., McKenzie, D. P., Westbrook, G. K., Bowen, A. N., 1987. Magmatism at rifted continental margins. Nature 330, 439-444. 
This chapter has been published as:

Burchardt, S., 2008. New insights into the mechanics of sill emplacement provided by field observations of the Njardvik Sill, Northeast Iceland. Journal of Volcanology and Geothermal Research 173, 280-288

3. New insights into the mechanics of sill emplacement provided by field observations of the Njardvik Sill, Northeast Iceland

\begin{abstract}
Sills are concordant sheet-like bodies of magma. Their mechanics of emplacement is an important but still not fully understood topic. The well-exposed basaltic Njardvik Sill in the extinct Tertiary Dyrfjöll Volcano in Northeast Iceland offers exceptionally clear insights into the mechanism of sill emplacement. The sill is multiple and consists of at least 7 units (sills) all of which were emplaced along a sharp contact between a rhyolitic intrusion and adjacent basaltic lava flows. Each sill unit was supplied with magma from an inclined sheet. The contacts between the sheets and the sill units are very clear and show that the sill units are much thicker than their feeder sheets. Since the Njardvik Sill consists of separate units, it obviously did not evolve into a homogeneous magma body. Nevertheless, the abrupt change in dip and thickness from inclined sheets to horizontal sills at this particular locality indicates that the earlier sills were influencing the stress field in their vicinity during the subsequent sheet injections. The local stresses around the newly formed sill units forced each of the subsequently injected sheets to change into sills. The Njardvik Sill can be followed laterally in a coastal section for $140 \mathrm{~m}$ until it ends abruptly at a fault that cuts the sill. Using these field observations as a basis, a numerical model shows how an inclined sheet opens up the contact between the felsic intrusion and the basaltic lava pile, along which the sill emplacement takes place. The results suggest that sill emplacement is primarily the result of stress rotation at contacts between layers of contrasting mechanical properties. There, the orientation of the maximum principal compressive stress $\sigma_{1}$ is horizontal. Hence, such contacts can represent interfaces along which sill emplacement is encouraged. Once a sill has been emplaced, it extends the stress field with a horizontal orientation of $\sigma_{1}$. Consequently, inclined sheets and dykes injected near the sill will be deflected into sills. The injection frequency of further sill units controls if the sill can grow into a larger magma body by mixing of the newly supplied with the initially injected magma. In case of the Njardvik Sill, the injection frequency was low, so subsequently emplaced sill units can be distinguished.
\end{abstract}




\subsection{Introduction}

Sills are sheet-like bodies of intrusive igneous rocks that conformably intrude into layers in the hosting crustal segment. Most sills are supplied with magma through dykes and form when magma gets trapped along its way to shallower depths in the crust. The mechanism of sill emplacement is still a matter of research because sills are recognised to enhance the petroleum prospectivity inside sedimentary basins (e.g. Jones et al., 2007). In addition, a general understanding of sill emplacement is part of the analysis of the formation of plutons in general and magma chambers in active volcanic regions in particular.

Sills have been studied in the field at many locations. Examples include the Traigh Bhan na Sgurra Sill on the Isle of Mull (Holness and Humphreys, 2003) and the Great Whin and the Midland Valley Sills, Great Britain (Francis, 1982; Goulty, 2005), and sills in Greenland, such as the Jameson Land Basin (Hald and Tegner, 2000) and Zig-Zag Dal (Upton et al., 2005). Other examples include sills in the Henry Mountains, Utah (Johnson and Pollard, 1973; Pollard and Johnson, 1973; Horsman et al., 2005; de Saint-Blanquat et al., 2006), the Pallisades Sill, New Jersey (Shirley, 1987), and sills in Lajitas, Texas (Barker, 2000) as well as in Karoo, South Africa (Chevalier and Woodford, 1999; Galerne et al., 2008). Geophysical methods have also been used to study sills in the Northern Rockall Trough (Thomson and
Hutton, 2004) and the Møre Basin, North Atlantic (Hansen and Cartwright, 2006) and, as fluid magma chambers below active volcanoes (Auger et al., 2001) and mid-ocean ridges (Sinton and Detrick, 1992; Mutter et al., 1995; Singh et al., 2006).

In addition to geological and geophysical field studies, there have been many theoretical studies on the mechanisms of sill emplacement. These latter include the analysis of conceptual models (Bradley, 1965; Roberts, 1970; Spence and Turcotte, 1985; Chevalier and Woodford, 1999), analogue experiments (Kavanagh et al., 2006), numerical (Malthe-Sorenssen et al., 2004), and analytical models (Anderson, 1938, 1942; Pollard and Johnson, 1973; Kerr and Pollard, 1998; Goulty, 2005).

Sill emplacement is commonly explained by magma storage at the so-called level of neutral buoyancy (Bradley, 1965; Williams and McBirney, 1979; Barker, 2000) where the magma has the same density as the surrounding rock. Recently however, layers with mechanically different properties, and weak interfaces in between, have been recognised to greatly influence the emplacement of magma and to be able to enforce sill emplacement (e.g. Johnson and Pollard, 1973; Hyndman and Alt, 1987; Holness and Humphreys, 2003; Kavanagh et al., 2006). However, the emplacement mechanism of sills is still not completely understood. A combination of field observ- 
ations and modelling could therefore provide more insights into this topic.

This study is based on field observations of a small multiple basaltic sill in the extinct Tertiary Dyrfjöll Volcano in North-
(Gustafsson, 1992; L. E. Gustafsson, pers. comm., 2006). During its lifetime it produced large volumes of silicic rocks that are now a part of the second largest rhyolitic area in Northeast Iceland.

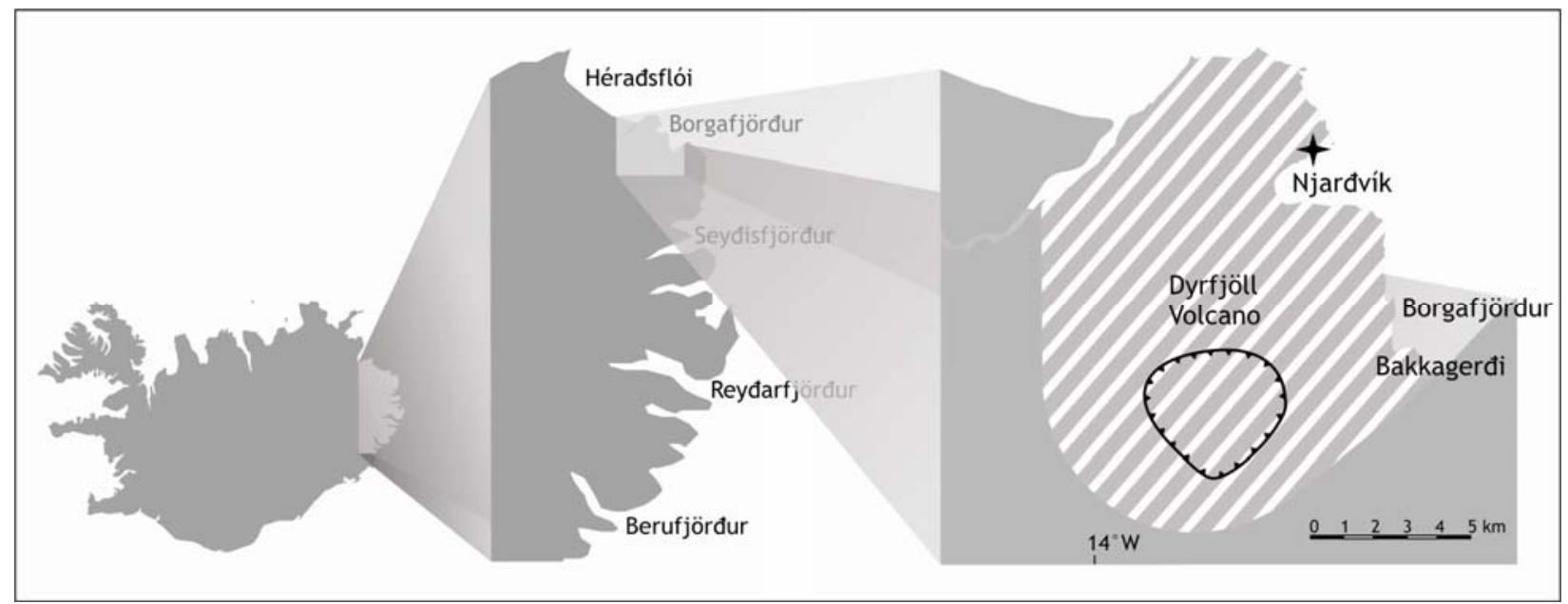

east Iceland (Fig. 3.1). The sill was fed from several inclined sheets that intruded a contact between basaltic lavas and a felsic intrusion. It represents an exceptionally well-exposed example of the geometry and the mode of emplacement of a sill. The first aim of this paper is, thus, to give a detailed description of the geometry of the Njardvik sill, its structure, and the inferred mode of emplacement. The second aim of the paper is to explain the field observations in terms of a simple numerical model. The purpose of this model is to provide a better understanding of the stress conditions that favour sill emplacement.

\subsection{Geological setting}

The Dyrfjöll Volcano is one of the extinct Tertiary central volcanoes (stratovolcanoes) exposed in Eastern Iceland (Fig. 3.1). It was active around $12 \mathrm{Ma}$
Figure 3.1. Location of the Dyrfjöll Volcano in Northeast Iceland. The site of the Njardvik Sill is indicated by a star.

The only comprehensive study on the Dyrfjöll Volcano so far was done by Gustafsson (1992) and was used as a basis for the author's field work.

As a result of glacial erosion, a vertical section of some 1100 metres through the Dyrfjöll Volcano is exposed in the cove of Njardvik. In its lowest part, at sea level, the section comprises acid intrusive rocks of the Njardvik Silicic Complex (Gustafsson, 1992). These shallow acid intrusions were emplaced into a succession of basaltic lava flows from the earlier eruptive history of the Dyrfjöll Volcano. In addition, they are associated with a considerable volume of acid extrusive rocks exposed on the flanks of the volcano. The highest part of the volcano, as presently 
exposed, is overlain by regional basalt lavas that buried the volcano after it became extinct.

The entire interior of the Dyrfjöll Volcano is dissected by numerous, mostly basaltic, inclined sheets and dykes. The inclined sheets form a swarm around a common centre (the crustal magma chamber that basaltic lava flows. On reaching the contact plane between the rhyolitic intrusion and the basalt, the inclined basaltic sheet changed its dip and propagated further along the horizontal interface. Contact metamorphism of the rhyolitic intrusion and its development of sill-parallel jointing indicate that the rhyofed the sheets) located in the Njardvik bay, whereas most dykes belong to a $\mathrm{N}$ striking swarm of regional dykes associated with the Dyrfjöll Volcano (Gustafsson, 1992; and own unpublished data). The multiple basaltic sill described in the next section (from now on referred to as the Njardvik Sill) is exposed on the northern shore of Njardvik (Fig. 3.1) and is fed by inclined Figure 3.2. View of the Njardvik Sill on the sheets.

\subsection{The Njardvik Sill}

The Njardvik Sill is a basaltic sill with an exposed length (strike dimension) of approximately $140 \mathrm{~m}$ and thickness of around $20 \mathrm{~m}$ (Fig. 3.2). The sill was clearly initiated when an inclined sheet dipping 46 degrees met and entered the horizontal contact between a flat-roofed rhyolitic intrusion belonging to the Njardvik Silicic Complex and the overlying emplaced between the light-coloured rocks of the Njardvik Silicic Complex (Gustafsson, 1992) and the overlying dark-coloured basaltic lavas of the Dyrfjöll Volcano. The multiple Njardvik sill is fed from eight inclined sheets. A step-and-stair geometry can be inferred in some places. View north, the sill terminates at a fault visible in the right side of the picture.

litic intrusion had cooled down before emplacement of the Njardvik Sill. Where the inclined basaltic sheet changes into a 
horizontal sill, the thickness of the intrusion increases from $0.55 \mathrm{~m}$ to more than $2 \mathrm{~m}$ (Fig. 3.3).

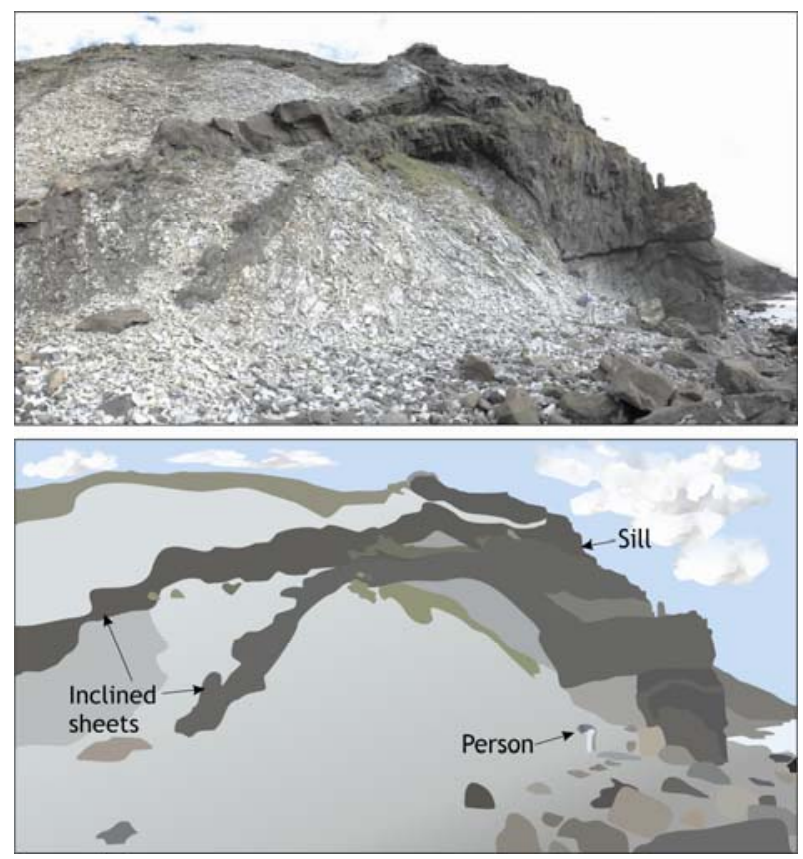

Figure 3.3. Western margin of the Njardvik Sill. Where the inclined sheets start to propagate horizontally they thicken considerably after a constriction. View northeast, the person provides a scale.

At least eight sheet injections can be traced into the sill. These injections resulted in gradual thickening and growth of the sill. However, the Njardvik Sill did not evolve into a homogeneous magma body since at least seven units can be distinguished where the sill reaches its maximum thickness (Fig. 3.4). This indicates that the time between subsequent emplacements of the parts (units) that constitute the sill was at least so long that a partial or complete cooling of a unit (fed by an inclined sheet) occurred before the emplacement of the next unit. Furthermore, a step-and-stair geometry of individual units occurs in the upper part of the sill (Fig. 3.2).

The Njardvik Sill terminates at the contact with a dip-slip fault striking $135^{\circ}$ and dipping $70^{\circ} \mathrm{E}$ (Fig. 3.2). Apparently, the sill is cut by the fault. The outcrop, however, is too limited to allow a determination of the type of displacement along the fault plane.

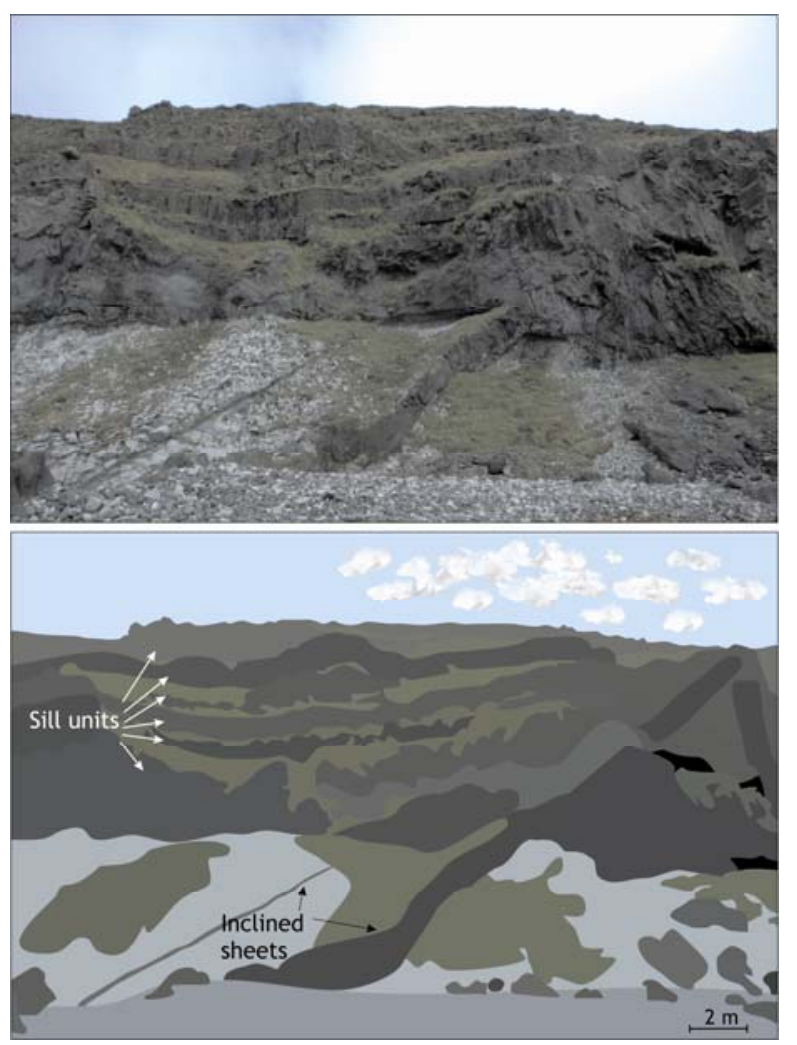

Figure 3.4. In the centre of the Njardvik Sill, at least seven individual units constitute the multiple sill. They can be distinguished by different jointing and a slightly different colour. View north.

Dyke emplacement in the vicinity was clearly influenced by the Njardvik Sill; for example a regional dyke generally striking $175^{\circ}$ and dipping $87^{\circ} \mathrm{W}$ changes its attitude so as to become parallel to the sill at a distance of less than one metre below the sill. Several inclined sheets dissected 
the Njardvik Sill at a time when it was probably mostly or completely solidified. These inclined sheets cut the sill but while their paths are inside the sill they change from their normal attitude to a sill-parallel attitude in some units (Fig. 3.5). Once the inclined sheet paths have passed through these units, their paths change back to their original attitude.
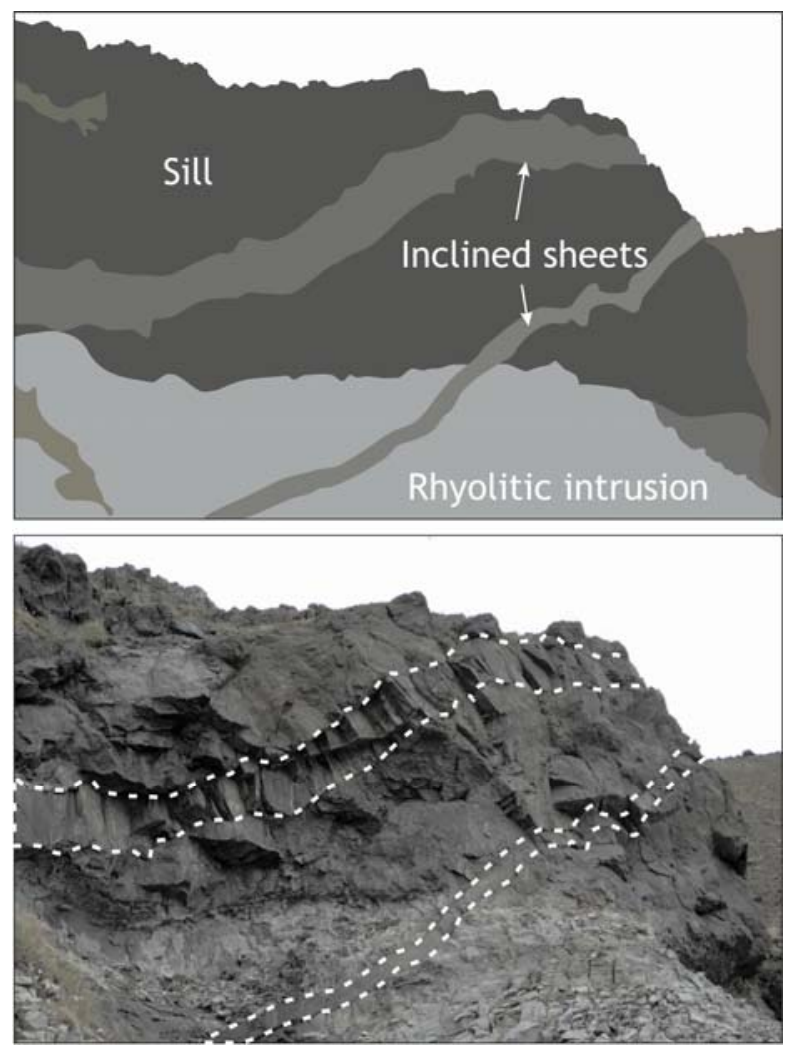

Figure 3.5. Two inclined sheets that cut the Njardvik Sill change their attitude while within some of the sill units but change back to their original attitude once they have propagated through them. View northeast, the upper inclined sheet has a thickness of $0.85 \mathrm{~m}$.

Field observations indicate the following schematic evolution of the Njardvik Sill (Fig. 3.6). From the stratified crustal magma chamber of the Dyrfjöll Volcano (Fig. 3.6A), rhyolitic magma was injected forming a shallow intrusion at a few hundred metres depth. This acid intrusion is a part of the Njardvik Silicic Complex (Fig. 3.6B; Gustafsson, 1992). The Njardvik Silicic Complex has mechanical properties contrasting with those of the adjacent basaltic lava flows. Consequently, in the conceptual model, when the inclined basaltic sheets subsequently injected from the shallow chamber met the upper contact between the rhyolitic intrusion and the basaltic lava above, the sheets changed into sills (Fig. 3.6C). These sill intrusions resulted in the formation of a sill consisting of several units, that is, the Nardvik Sill (Fig. 3.6D). After solidification and cooling down of the entire Njardvik Sill, the later-formed inclined sheets and dykes were able to cut through it (Fig. 3.6E).

\subsection{Numerical modelling of sill formation}

Using the field observations as a basis, a numerical model was constructed to test the mechanical aspects of the conceptual model presented in Fig. 3.6 focussing on the emplacement of the first sill unit. For this purpose, the Finite Element modelling software COMSOL Multiphysics 3.3 was used. This program is based on Finite Element Methods (FEM). There, the geometry of a model is first discretised into a set of volumetric or planar elements and then the differential equations that govern the problem are solved numerically to obtain displacements, magnitude, and orientation of stresses and strains (Zienkiewicz, 1977; Logan, 2002). 

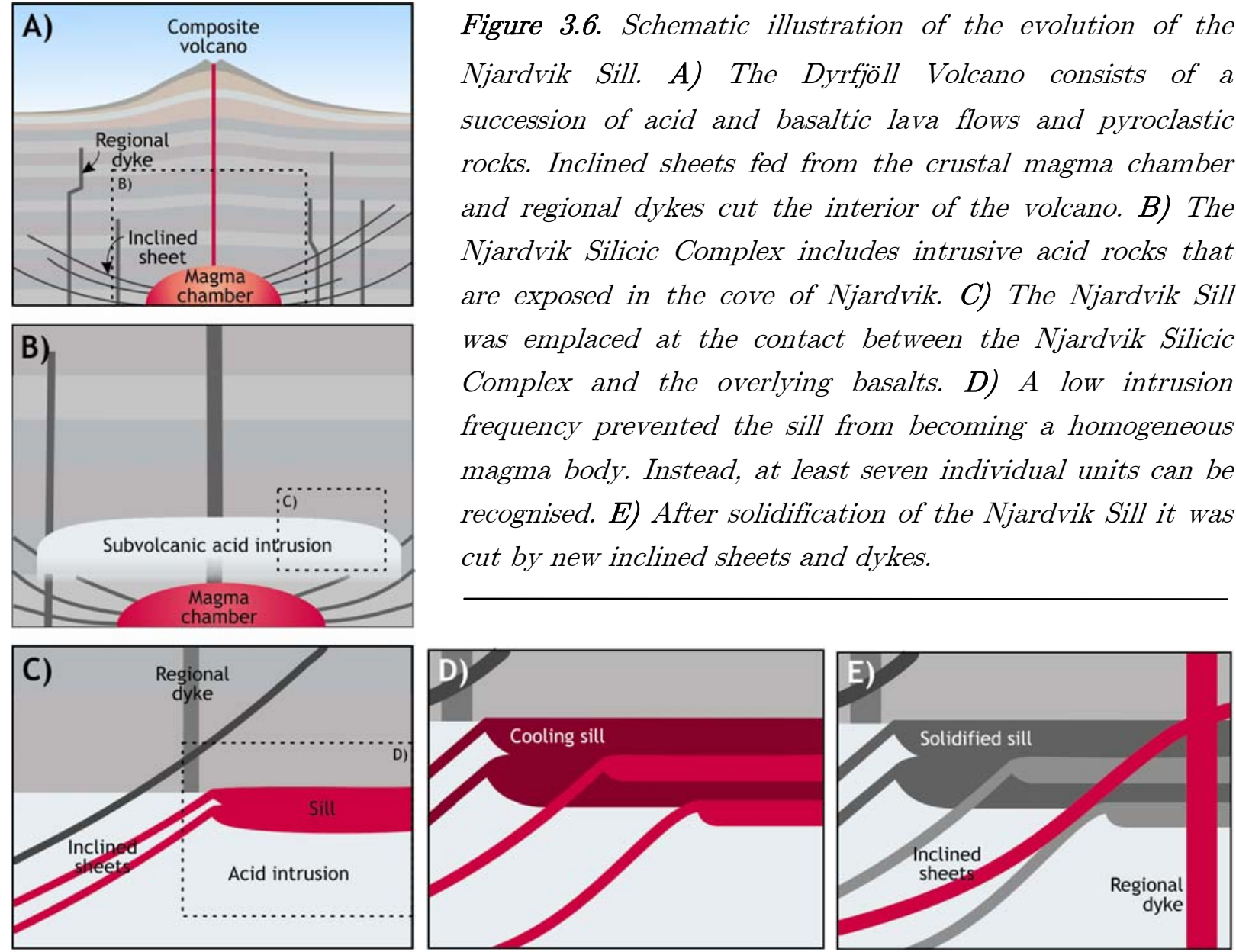

The geometry of the FE model presented here is derived from generalised field observations of the Njardvik Sill and illustrated in Fig. 3.7. An inclined sheet with zero initial thickness and a dip of $45^{\circ}$ meets the interface between the rhyolite intrusion and a basaltic lava flow. Unfortunately, the properties of the interface between both layers are unknown and cannot be reconstructed.

In the model, the contact zone is described by a Coulomb friction model that is based on the Navier-Coulomb criterion for rock failure (e.g. Hoek, 1968). This fracture criterion defines the onset of rupture when the intrinsic shear resistance is overcome by an applied shear stress. Fracture propagation is possible when the shear stress is high enough to sustain movement as described by the product of the normal stress and the coefficient of internal friction. According to Pollard and Johnson (1973), in nature, there is always some friction between layers, but a shear stress created by this friction is probably negligible in many cases compared to the stresses created in the layer as a result of the intrusion of magma. However, the influence of cohesion along the interface between basalt and rhyolite has been tested in the model by applying different values for the cohesion but no significant differences in opening width or length along the contact zone occur. This might indicate that the resulting shear stress at the interface is high enough to initiate 


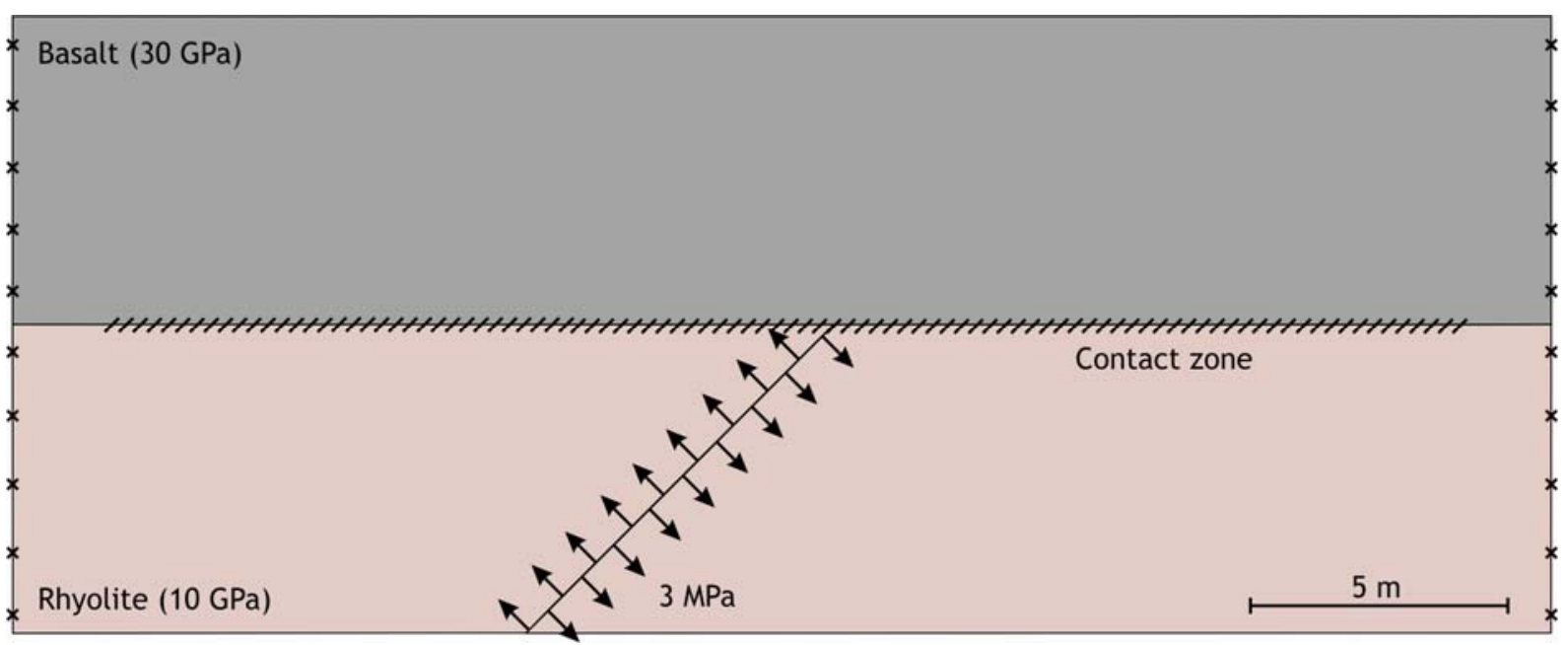

Figure 3.7. Geometry of the numerical model presented in Figures 3.8 to 3.10. The geometry and boundary conditions are based on field observations of the Njardvik Sill.

rupture, and once the shear resistance of the interface is overcome the opening width is determined by the magma pressure. Normally, a high value of cohesion could prevent the contact from opening. In contrast, there is no cohesion or friction between the sides of the fracture representing the inclined sheet. The Poisson's ratio of the host rocks is assumed to be 0.25 , a typical value for most solid crustal rocks (Bell, 2004). Using available data on Icelandic rocks, Young's modulus of the basaltic lava flow is taken as $30 \mathrm{GPa}$ whereas that of the rhyolite intrusion as 10 GPa (Oddson, 1984; Carmichael, 1989; Egilsson et al., 1989). The model was fastened along its lateral margins (Fig. 3.7), using the condition of no displacement. This represents the small aerial extent of deformation around the intrusion (cf. Pollard and Johnson, 1973). The excess pressure used for the inclined sheet is defined as $3 \mathrm{MPa}$, which is in the range of the tensile strength of crustal rocks (Jaeger and Cook, 1979).
The model results as to the magnitude of the maximum principal tensile (minimum principal compressive) stress $\sigma_{3}$ is shown by the contours in Fig. 3.8, the contours of the von Mises shear stress are shown in Fig. 3.9.

The distribution of tensile stress in the model (Fig. 3.8) is characterised by a maximum below the lateral end of the opened contact to the right of the inclined sheet. In addition, tensile stress concentrations occur at the tips of the contact zone on both sides. The von Mises shear stress (Jaeger and Cook, 1979; Benham et al., 1996) concentrates mainly below the tip region of the opened contact that is subsequently used for the sill (Fig. 3.9). This stress distribution is in agreement with photoelastic gelatine experiments and analytical solutions by Pollard and Johnson (1973). According to Anderson (1938), sheet-like intrusions propagate as a result of high tensile stress concentrations near the tip that enable the intrusion to "wedge open" the host rock. 


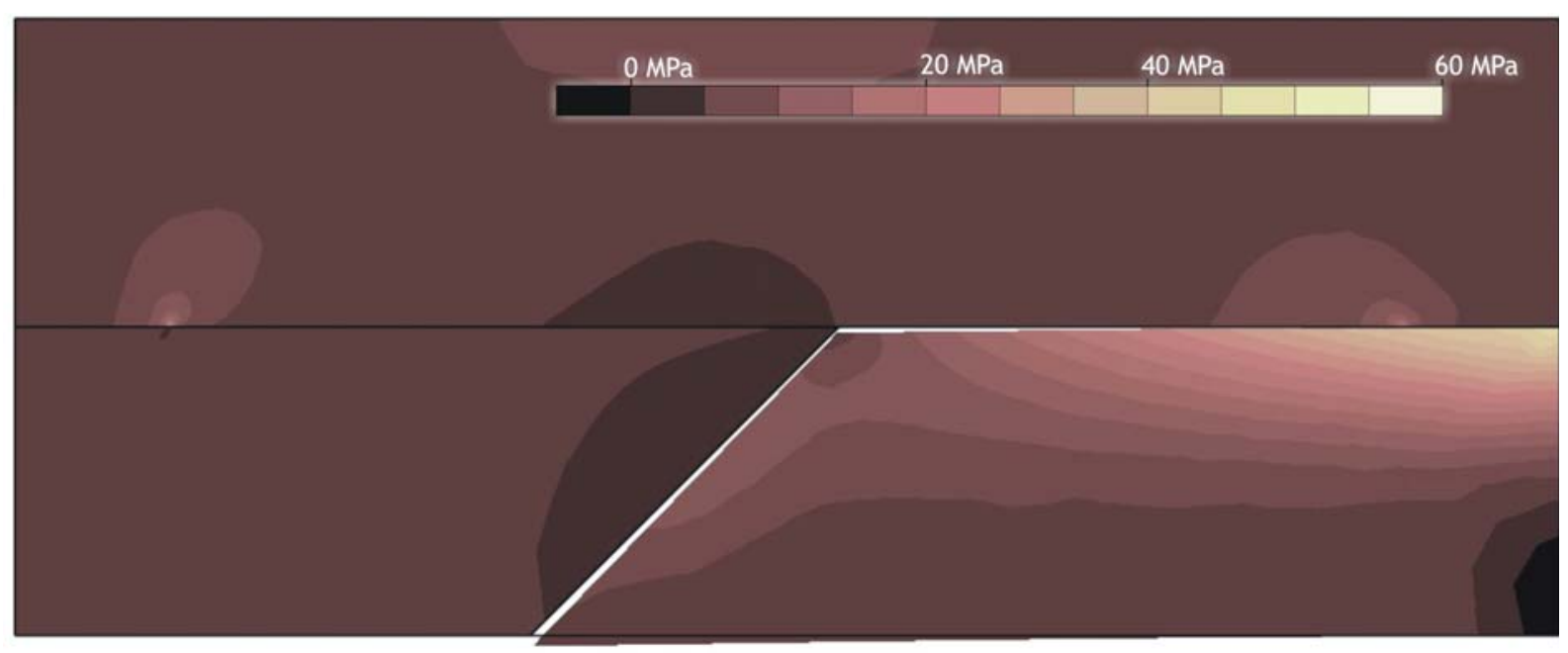

Figure 3.8. Contours of the minimum principal compressive (maximum principal tensile) stress $\sigma_{3}$. The geometry of the model is illustrated in Figure 3.7.

The deformation of the model shows opening of the contact zone to the right of the sheet but not to the left. This is in agreement with the field observation of the Njardvik Sill (cf. Figs. 3.2, 3.8, 3.9). The maximum opening width along the contact zone is $0.12 \mathrm{~m}$ whereas the opening of the fracture representing the inclined sheet is $0.2 \mathrm{~m}$. In the field, the inclined sheet feeding the first unit of the Njardvik Sill has a thickness of $0.55 \mathrm{~m}$. This might indicate that the overpressure of $3 \mathrm{MPa}$ applied in the model is lower than the overpressure of the sheet in Njardvik. In this context, the very small opening width of the contact zone is a result of the too low value of the overpressure. However, the actual geometry and opening width of the sill in the model is not comparable to the field observations since it is not possible to model influx of magma with an overpressure into the newly formed sill in a static model. It is, however, not the purpose of the model to make quantitative predictions but to provide insight into the mechanisms acting during sill emplacement in case of the Njardvik Sill.

For the given boundary conditions, the trajectories of $\sigma_{1}$ are perpendicular to the opened contact zone on the right side of the inclined sheet (Fig. 3.10). The trajectories of the maximum principal compressive stress $\sigma_{1}$ reflect the direction in which extension-fracture propagation is most likely whereas shear fractures make a certain angle (commonly $<45^{\circ}$ ) to the direction of $\sigma_{1}$ (Jaeger and Cook, 1979). The vertical orientation of $\sigma_{1}$ below the newly opened contact zone might explain the observed thickening of the first sill unit by fracturing of the area below the sill. Below this area, $\sigma_{1}$ trajectories are horizontal favouring the diversion of subsequently injected sheet into further sill units.

The limitations of our model include the purely elastic behaviour of the material and its instantaneous deformation. As mentioned above, the problem of sill emplacement and propagation is not an 


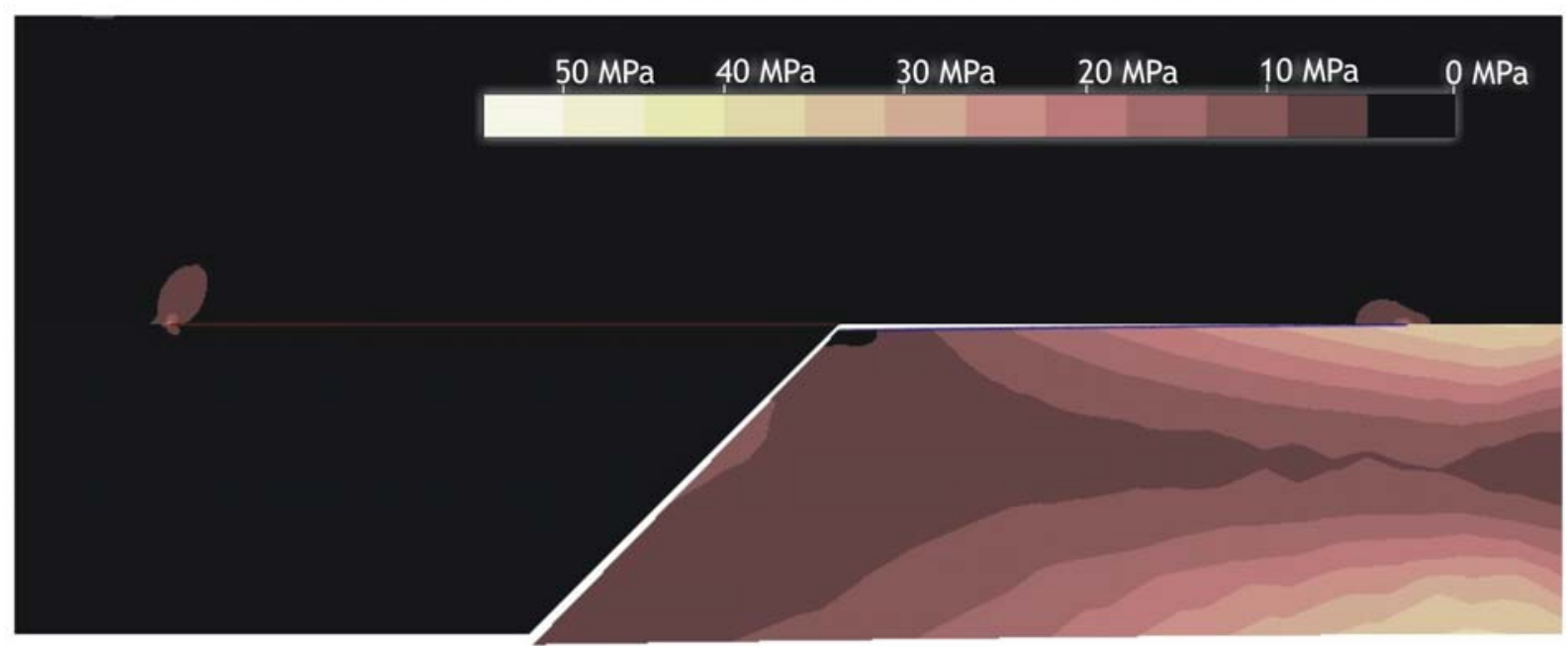

Figure 3.9. Contours of the von Mises shear stress. The geometry of the model is illustrated in Figure 3.7.

entirely static one. In addition, thermal effects, which clearly played a role as indicated by contact metamorphism of the rhyolitic host rock, have not been regarded in the models.

\subsection{Emplacement of the Njardvik Sill}

A mechanical model for the emplacement of the Njardvik Sill should be able to explain the field observations (Section 3.3) based on the results of the numerical model in Section 3.4. Like other sheet intrusions, the Njardvik Sill formed as a magma-driven fracture. It follows that its emplacement was primarily controlled by the internal magmatic overpressure, the local orientation of the principal stresses in the host rock, and the mechanical properties of the host rock and the interface between the rhyolite intrusion and the adjacent basaltic lava flows.

In an extensional stress regime, such as it is typical for rift zone volcanoes as the one in which the Dyrfjöll Volcano was situated, the maximum principal compressive stress, $\sigma_{1}$, is commonly vertical, whereas $\sigma_{3}$ is horizontal. Such a regional stress field controlled the emplacement of the $\pm \mathrm{N}$-striking regional dykes in the Dyrfjöll area. Within the volcano itself, there was an additional local stress field around the crustal magma chamber that fed the swarm of inclined sheets. Initial sill formation requires the development of a local stress field within the volcano with a horizontal orientation of $\sigma_{1}$. This local stress field was probably primarily the result of rotation of $\sigma 1$ from its normal vertical orientation to a horizontal one at the contact between the rhyolitic intrusion and the adjacent basaltic lava flow above.

Such a local re-orientation of the principal stress directions can be achieved by the presence of layers with different mechanical properties (see Section 3.6.1). Within the Tertiary lava pile of Iceland, contrasting mechanical properties between 


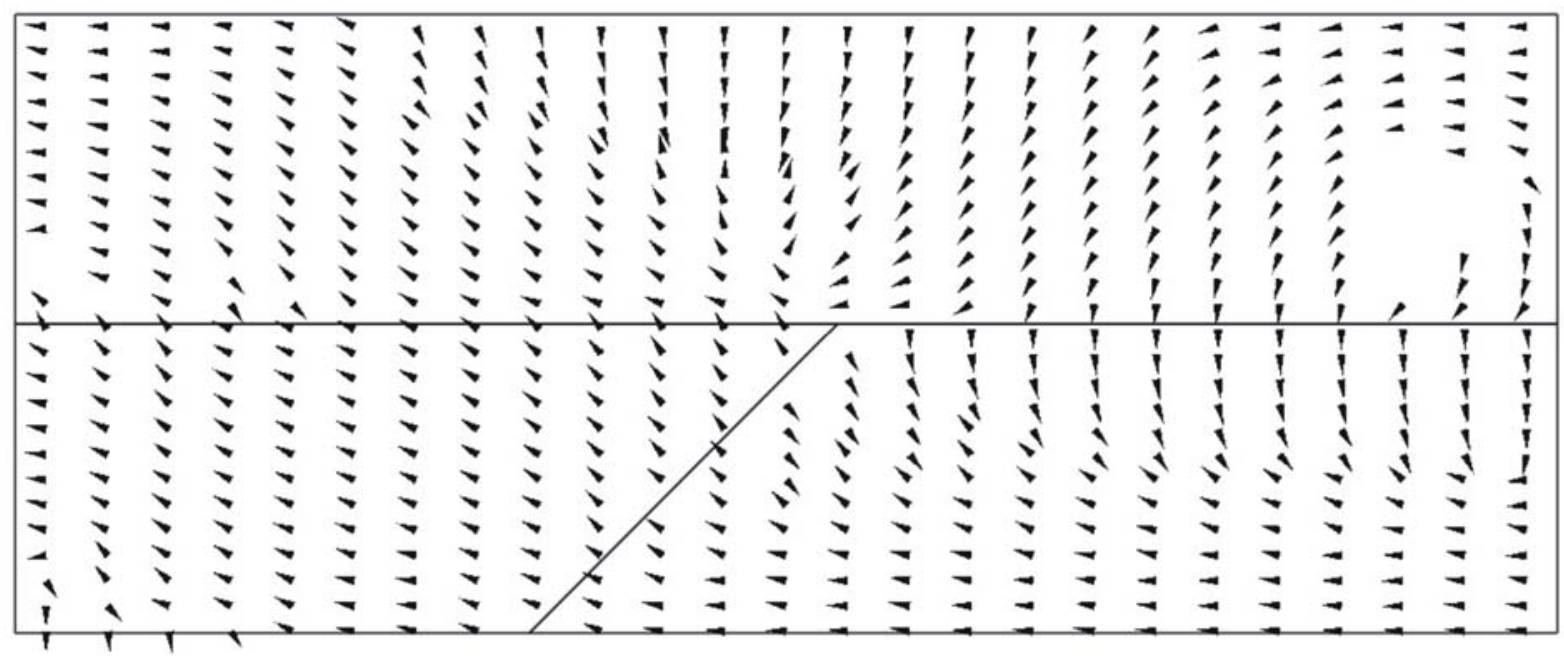

Figure 3.10. Trajectories of the maximum principal compressive stress $\sigma_{1}$ representing pathways for ideal fracture propagation. The geometry of the model is illustrated in Figure 3.7.

layers are most commonly found within central volcanoes, because there the rocks (intrusive and extrusive) show the greatest variety in mechanical properties (acid, intermediate, basaltic; igneous as well as sedimentary, mainly volcaniclastic). Rocks of such a variety are, indeed, abundant within in the Dyrfjöll Volcano. For the Njardvik Sill in particular, the contrast between the rhyolitic Njardvik Silicic Complex (Gustafsson, 1992) and the overlying basaltic lava flows might have caused a local stress rotation from a $\sigma_{1}$ parallel to the inclined sheets (following the $\sigma_{1}$ stress trajectories around the magma chamber that fed the sheet dipping with around $45^{\circ}$ towards the chamber) towards a horizontal orientation. In addition, the mechanical properties of the interface between rhyolite and basalt might have enhanced stress rotation and, hence, the intrusion of the first sill unit of the Njardvik Sill. Unfortunately, this interface is not exposed so one can only speculate about its properties. As detailed in the description of the numerical model in Section 3.4, the interface is modelled as a contact defined by a Coulomb friction model.

The injection of the first sill unit definitely altered the stress field in its vicinity (cf. Fig. 3.10 where the direction of the maximum compressive stress induced by the formation of the first sill at the interface appears vertical at the contact zone but horizontal at some short distance underneath it). This can be seen from subsequently injected sheets being diverted from their original paths and deflected into sills. Therefore, the first sill installed a local stress field that was enhancing further sill emplacement by following sheets. The local stress field around the first sill may have had a very small extend; however, it was able to divert at least 7 other inclined sheets and force them to join the first sill as subsequent units of the Njardvik Sill. In addition, the small regional dyke that changes its dip from $87^{\circ}$ to being sub-parallel to the 
Njardvik Sill less than $1 \mathrm{~m}$ below the sill is an example for the reach of the local stress field around it.

The injection frequency of new sheets, that is, how frequently the first sill received new magma through inclined sheets, controlled whether the first sill developed into a larger, homogeneous magma body, and thus eventually into a shallow magma chamber. The field observations of the Njardvik Sill show clearly that the first injected sill had at least partly solidified before the next inclined sheet near the sill was injected (Figs. 3.2, 3.4). Similarly, during subsequent sill injections in this place, all the previous sills had solidified. As a consequence, the first sill (and the subsequent ones) had no chance to develop into a shallow magma chamber. Consequently, the multiple Njardvik Sill is a complex consisting of at least 7 individual sills or units (Fig. 3.4). However, it should be noted that initially solidified sills could later on become partially melted and thus potentially form homogeneous magma bodies when enough heat can be accumulated through repeated injection of later sills (Annen and Sparks, 2002). Even though the individual sills in the Njardvik Sill had partly solidified, it is obvious that their influence on the local stress field was still existent during subsequent sheet emplacement.

Even when the Njardvik Sill was probably entirely solidified, its local stress field was - at least within some of the sill units able to locally divert inclined sheets that cut the Njardvik Sill (Fig. 3.5).
The thickening of the first sill unit from $0.55 \mathrm{~m}$ in the inclined sheet to more than $2 \mathrm{~m}$ in the sill (Fig. 3.3) is probably a result of continuing magma supply through the inclined sheet in connection with the mechanical response of the rhyolite below. Pollard and Johnson (1973) explain an increase in thickness observed in the Maiden Creek Sill, Henry Mountains, by a mechanism called "ductile blunting". It has been deduced from observations of the severe deformation of the host rock around the termination of the sill. During sill propagation the formation of closely-spaced cataclastic shear planes caused a blunting of the sill termination and an increase in sill thickness. However, since this mechanism is only partly applicable to brittle rocks and the host rock of the Njardvik Sill was most likely completely solidified when the sill was emplaced (see Section 3.3), ductile blunting cannot have had a great influence. In addition, since the termination of the Njardvik Sill is not exposed because it is cut by a fault (Fig. 3.2), the radius of curvature of the sill termination that is an indication for the brittle or ductile behaviour of the host rock (Pollard and Johnson, 1973) cannot be measured and the deformation around the termination cannot be analysed, it is not possible to test the influence of ductile blunting.

Thus, the mechanism of emplacement of the Njardvik Sill was strongly controlled by rotation of the principal stresses as a result of the contrasting mechanical properties of the host rock layers (basalt 
and rhyolite) and probably the interface between these layers. At the time when the first inclined sheet was deflected into a sill a local stress field existed along this interface with a horizontal orientation of $\sigma_{1}$ that enforced sill emplacement. After its emplacement the first sill created its own local stress field by extending the area of a horizontal $\sigma_{1}$. As a consequence, the emplacement of subsequent sill units was enhanced.

\subsection{Discussion}

\subsubsection{Mechanisms of sill emplacement}

Sill emplacement is commonly explained by magma storage at the so-called "level of neutral buoyancy" (LNB; Glazner and Ussler, 1988; Walker, 1989; Ryan, 1993) where the density of the magma equals the density of the surrounding crust. Such density- or buoyancy-controlled sillemplacement models have been discussed, for example, by Bradley (1965), Williams and McBirney (1979), Barker (2000), and Kavanagh et al. (2006), and developed into a general model for magma storage or shallow magma-chamber formation by Glazner and Ussler (1988), Ryan (1993), Lister and Kerr (1991), and Dahm (2000). However, the concept of a LNB is not consistent with geological and geophysical observations; e.g. felsic intrusions could not occur inside a denser basaltic crust as it is the case inside the Dyrfjöll Volcano (cf. Fig. 3.6).

According to Vigneresse et al. (1999), the intrusion of (granitic) magma into an isotropic and homogeneous brittle crust locally alters the stress field. In a tensional stress regime such as the rift zone in Iceland, the vertical intrusion plane becomes horizontal when the horizontal stress components $\left(\sigma_{2}\right.$ and $\left.\sigma_{3}\right)$ overcome the lithostatic load (vertical stress, $\sigma_{1}$ ). This is possible because the magma pressure in a vertical conduit or dyke is added to the horizontal $\sigma_{3}$. During the ascent of the magma the vertical $\sigma_{1}$ decreases. As soon as $\sigma_{1}$ is less than the combined magma pressure and $\sigma_{3}$, the intrusion plane becomes horizontal, i.e., the dyke changes into a sill (Anderson, 1942).

Only during the last decades has it been recognised that the presence of layers with contrasting rock mechanical properties greatly influences the emplacement of magma especially in the upper crust. Heterogeneities and anisotropies can be regarded as pre-existing stress guides that facilitate stress re-orientation because layers of weaker material lower the stress level at which stress rotation occurs by lowering the stress differential (Vigneresse et al., 1999). Many field observations of sills underline the importance of crustal layering during the emplacement of a sill (e.g. Johnson and Pollard, 1973; Holness and Humphreys, 2003). Examples of sills emplaced between layers of different mechanical properties include e.g. the Sonju Lake Intrusion, Minnesota (Maes et al., 2007), sills in the Paiute Ridge area, Nevada (Valentine and Krogh, 2006), the Papoose Flat Pluton, California (de SaintBlanquat et al., 2001), and the Black Mesa 
Pluton and other intrusions in the Henry Mountains, Utah (Pollard and Johnson, 1973; de Saint-Blanquat et al., 2006). These observations are also supported by results of analogue experiments (Hyndman and Alt, 1987; Kavanagh et al., 2006).

Some authors suggest that, in addition to the existence of rock mechanical layering, the properties of the interface between individual layers control the emplacement of sills. E.g., Mudge (1968) suggested that well-defined parting surfaces, i.e., weak or open contacts such as bedding planes or unconformities, are prerequisites for sill emplacement. Similar results have also been obtained in analogue modelling. For example, Kavanagh et al. (2006) observed sill formation in gelatine experiments at a weak interface between two layers with the same mechanical properties. For a mechanically layered crustal analogue, the presence of an interface is not sufficient; instead, a positive rigidity anisotropy with an upper more rigid layer in addition to a weak interface between the layers is required (Kavanagh et al., 2006). This is a striking analogue for the Njardvik Sill that was emplaced between relatively rigid basaltic lava flows overlying a less rigid rhyolitic intrusion (e.g. Fig. 3.6).

I therefore infer that the primary controls of sill formation are abrupt stress rotations whereby the principal compressive stress $\sigma_{1}$ becomes horizontal and the minimum principal compressive stress $\sigma_{3}$ vertical. Such stress rotations occur preferentially in a layered crust with considerable contrasts between the mechanical properties of individual layers. When in addition this local stress field coincides with a weak or open horizontal contact between layers, sill emplacement can be encouraged.

\subsubsection{Dykes as feeders for sills}

The feeders to most sills are thought to be inclined sheets or dykes. In some cases dykes are seen to change into sills, but the feeders for sills are often poorly exposed in the field so that a clear connection between the feeder and the sill is commonly lacking (Johnson and Dunham, 2001). In this respect, the Njardvik Sill offers an exceptionally clear example for the feeding relationships between inclined sheets and the sills they fed. As is shown in Figures 3.2, 3.3 and 3.4, and illustrated schematically in Figure 3.6, all the units of the Njardvik Sill are fed from the side by inclined sheets.

While there are few as clear examples of the connection between the feeders and the sills as the Njardvik Sill, several other field examples with direct connection between feeders and sills are known. These include the sills of Great Whin and the Midland Valley (Francis, 1982; Goulty, 2005), a sill in Lajitas, Texas (Barker, 2000), sills in the Jameson Land Basin, East Greenland (Hald and Tegner, 2000), and in the North Rockall Trough (Thomson and Hutton, 2004) and the Møre Basin (Hansen and Cartwright, 2006), North Atlantic. Even though the feeder dykes of most sills are not exposed or directly linked to the sill in outcrops, feeding relationships and the geometry of the feeder can sometimes be inferred from 
magmatic foliations or the preferred orientation of the magnetic susceptibility (e.g. de Saint-Blanquat et al., 2006; Maes et al., 2007; Palmer et al., 2007).

The geometry of a sill may depend on how it is fed. In plan view, the geometries of sills are of two main types: radially symmetrical and bilaterally symmetrical. Radially symmetrical sills are thought to be fed from the centre (e.g. Thomson and Hutton, 2004; Hansen and Cartwright, 2006), whereas bilaterally symmetrical sills are fed from one side of the sill. While radially symmetrical sills do occur, some of which develop into laccoliths (Pollard and Johnson, 1973), many and perhaps most sills are actually bilaterally symmetrical. For example, there is evidence that the Great Whin and Midland Valley Sills (Francis, 1982; Goulty, 2005) have a bilateral symmetry. Similarly, Anderson's (1942) conceptual model, partly based on field observations, suggests sill emplacement through one of the walls of a vertical feeder dyke. And, of course, the Njardvik Sill is clearly bilaterally symmetrical (Figs. 3.2, 3.4, 3.6).

\subsubsection{Sills as potential magma chambers}

Although the Njardvik Sill did not develop into a homogeneous magma body that could act as a magma chamber, there is abundant evidence that sills commonly develop into shallow magma chambers. E.g. magma chambers along fast-spreading mid-ocean ridges are known to be sill-like (Sinton and Detrick, 1992; Mutter et al., 1995; Singh et al., 2006). Larsen and Marcussen (1992) also proposed that sills acted as open crustal reservoirs feeding flood basalt volcanism. Aditionally, Németh and Martin (2006) outline a genetic relationship between a complex of sills and dykes and a diatreme in western Hungary. There is also geochemical and field evidence for the supply of magma for eruptions from sill-like chambers in different tectonic environments (e.g., Upton et al., 2005).

Furthermore, according to Pollard and Johnson (1973), sills are the preliminary stage of the development of laccoliths and other bigger intrusive bodies. This is in agreement with Glazner et al. (2004) who suggest that large plutons can form through the incremental accumulation of many small igneous bodies. Sheeted emplacement, which can be interpreted as the stacking of sills or sill units, has been observed in many large plutons in different tectonic settings (Hutton, 1992). Examples for plutons that evolved from the coalescence of several sills or sheet-like intrusions include several laccoliths on the Isle of Elba, Italy (Rocchi et al., 2002), the Birch Creek pluton (Barton et al., 1995), and the Papoose Flat pluton, California (de Saint-Blanquat et al., 2001).

A similar observation of a sill that consists of more than one unit is the Maiden Creek Sill in the Henry Mountains, Utah (Horsman et al., 2005). There, the initially emplaced sill was followed by a subsequent second sill that intruded immediately adjacent to the first sill. In agreement with the mechanical model proposed for the Njardvik Sill (see Section 3.5), Horsman et al. (2005) suggest that the intrusion of the 
first sill mechanically controlled the emplacement of the second sill through a thermal and/or strength anisotropy imparted by the emplacement of the first sill. This observation from both the Maiden Creek and the Njardvik Sill indicates that sill emplacement mechanically enhances the intrusion of further sills by extending the area of a local stress field with $\sigma_{1}$ horizontal that is thus favourable for sill emplacement.

The development of a sill into a magma chamber depends then on the magma supply rate into the sill. If the injection frequency is high enough, the magma inside the sill remains liquid and can mix with newly injected magma. In case of the Njardvik Sill, the injection frequency was relatively low. This resulted in the - at least partial - solidification of individual units before the next unit was emplaced. As a consequence, mixing among the layers by convection was prevented. Hence, the Njardvik Sill did not have the chance to evolve into a magma chamber.

\subsection{Conclusions}

Based on field studies of the multiple Njardvik Sill in Northeast Iceland, as well as numerical modelling, the following conclusions regarding its mechanics of emplacement and sill emplacement in general may be drawn.

The Njardvik Sill was initiated when an inclined sheet met the contact between subvolcanic rhyolite of the Njardvik Silicic Complex and the overlying basaltic lava flows inside the Dyrfjöll Volcano. The local stress field that existed at the interface between these mechanically contrasting layers was characterised by a horizontal orientation of the maximum principal compressive stress $\sigma_{1}$ that differed significantly from the stress field in which the inclined sheet was propagating. As a result, the inclined sheet was forced to intrude along the interface as a sill. Therefore, stress rotation as a consequence of mechanical layering and the presence of weak interfaced between layers can be regarded as a condition for sill emplacement in the upper crust.

The emplacement of the first sill increased the sphere of influence of the local stress field with $\sigma_{1}$ being horizontal. Consequently, subsequently injected inclined sheets near the sill were deflected into sills forming additional units of the Njardvik Sill. Hence, the emplacement of a sill enhances the emplacement of further sills that can add to its magma volume.

The time between successive sill emplacements in the Njardvik Sill was sufficient for the (at least partial) solidification of the previously formed sill unit. This prevented mixing of the individual units and thus the homogenisation of the Njardvik Sill. Hence, at least seven units can be distinguished inside the sill (Fig. 3.4). Therefore, the injection frequency is a controlling parameter deciding if a sill can develop into a larger magma body that is eventually able to act as a magma reservoir for dyke emplacement. For this, the injection frequency into a sill must be high enough to avoid the solidification of previous 
magma batches or to provide enough heat to re-melt the already solidified parts of the sill.

\subsection{References}

Anderson, E. M., 1938. The dynamics of sheet intrusions. Proceedings of the Royal Society of Edinburgh 58, 242-251.

Anderson, E. M., 1942. The Dynamics of Faulting and Dyke Formation with Applications to Britain. Oliver \& Boyd, London.

Annen, C., Sparks, R. S. J., 2002. Effects of repetitive emplacement of basaltic intrusions on thermal evolution and melt generation in the crust. Earth and Planetary Science Letters 203, 937-955.

Auger, E., Gasparini, P., Virieux, J., Zollo, A., 2001. Seismic evidence of an extended magmatic sill under Mt. Vesuvius. Science 294, 1510-1512.

Barker, D. S., 2000. Emplacement of a xenolithrich sill, Lajitas, Texas. Journal of Volcanology and Geothermal Research 104, 153-168.

Barton, M., Ghidotti, G., Holden, P., Goodwin, L., Heizler, M., 1995. Time-space evolution of a two-mica granite; the Birch Creek Pluton, CA, USA. In: Brown, M., Piccoli, P., (eds.), The Origin of Granites and Related Rocks. U. S. G.

S. Circular 1129, 18-19.

Bell, F. G., 2004. Engineering Properties of Soils and Rocks. Blackwell, Oxford, 482 pp.

Benham, P.P., Crawford, R.J., Armstrong, C.G., 1996. Mechanics of Engineering Materials. Prentice Hall, New Jersey.

Bradley, J., 1965. Intrusion of major dolerite sills. Transactions of the Royal Society of New Zealand 3, 27-55.

Carmichael, R. S., 1989. Practical Handbook of Physical Properties of Rocks and Minerals. CRC Press, Boca Raton, Boston.

Chevalier, L., Woodford, A., 1999. Morphtectonics and mechanism of emplacement of the dolerite rings and sills of the western Karoo, South Africa. South African Journal of Geology 102, 43-54.
Dahm, T., 2000. On the shape and velocity of fluid-filled fractures in the Earth. Geophysical Journal International 142, 181-192.

de Saint-Blanquat, M., Law, R. D., Bouchez, J.L., Morgan, S. S., 2001. Internal structure and emplacement of the Papoose Flat pluton: An integrated structural, petrographic, and magnetic susceptibility study. Geological Society of America Bulletin 113, 976-995.

de Saint-Blanquat, M., Habert, G., Horsman, E., Morgan, S. S., Tikoff, B., Launeau, P., Gleizes, G., 2006. Mechanisms and duration of nontectonically assisted magma emplacement in the upper crust: The Black Mesa pluton, Henry Mountains, Utah. Tectonophysics 428, 1-31.

Egilsson, D., Hardason, B. A., and Jonsson, B., 1989. Dynamic properties of rock. Yearbook of the Engineering Association of Iceland, pp. 226-233 (in Icelandic).

Francis, E. H., 1982. Magma and sediment: 1. Emplacement mechanism of late Carboniferous tholeiite sills in northern Britain. Geological Society of London 139, 1-20.

Galerne, C. Y., Neumann, E. R., Planke, S., 2008. Emplacement mechanisms of sill complexes: Information from the geochemical architecture of the Golden Valley Sill Complex, South Africa. Journal of Volcanology and Geothermal Research 177, 425-440.

Glazner, A. F., Ussler, W., 1988. Trapping magma at midcrustal density discontinuities. Geophysical Research Letters 15, 673-675.

Glazner, A. F., Bartley, J. M., Coleman, D. S., Gray, W., Tayler, R. Z., 2004. Are plutons assembled over millions of years by amalgamation from small magma chambers? G. S. A. Today 14 doi: 10.1130/10525173(2004)013 <0004:APAOMO>.

Goulty, N. R., 2005. Emplacement mechanism of the Great Whin and Midland Valley dolerite sill. Journal of the Geological Society, London 162, 1047-1056.

Gustafsson, L. E., 1992. Geology and Petrography of the Dyrfjöll Central Volcano, Eastern Iceland. Berliner Geowissenschaftliche Abhandlungen, Reihe A, Band 138. 
Hald, N., Tegner, C., 2000. Composition and age of tertiary sills and dykes, Jameson Land Basin, East Greenland: relation to regional flood volcanism. Lithos 54, 207-233.

Hansen, D. M., Cartwright, J., 2006. Saucershaped sill with lobate morphology revealed by 3D seismic data: implications for resolving a shallow-level sill emplacement mechanism. Journal of the Geological Society, London 163, 509-523.

Hoek, E., 1968. Brittle Fracture of Rock. In: Stagg, K. G., Zienkiewicz, O. C. (eds.), Rock Mechanics in Engineering Practice. J. Wiley, London, 99-124.

Holness, M. B., Humphreys, M. C. S., 2003. The Traigh Bhan na Sgurra Sill, Isle of Mull: flow localization in a major magma conduit. Journal of Petrology 44, 1961-1976.

Horsman, E., Tikoff, B., Morgan, S., 2005. Emplacement-related fabric and multiple sheets in the Maiden Creek sill, Henry Mountains, Utah, USA. Journal of Structural Geology 27, 1426-1444.

Hutton, D. H. W., 1992. Granite sheeted complexes: evidence for diking ascent mechanism. Transactions of the Royal Society of Edinburgh 83, 377-382.

Hyndman, D. W., Alt, D., 1987. Radial dikes, laccoliths, and gelatine models. Journal of Geology 95, 763-774.

Jaeger, J. C. and Cook, N. G. W., 1979. Fundamentals of Rock Mechanics. Methuen, London, 515 pp.

Johnson, A. M., Pollard, D. D., 1973. Mechanics of growth of some laccolithic intrusions in Henry Mountains, Utah. 1. Field observations, Gilberts model, physical properties and flow of magma. Tectonophysics 18, 261-309.

Johnson, G. A. L., Dunham, K. C., 2001. Emplacement of the Great Whin Dolerite Complex and the Little Whin Sill in relation to the structure of Northern England. Proceedings of the Yorkshire Geological Society 53, 177186.

Jones, S. F., Wielens, H., Williamson, M. C., Zentilli, M., 2007. Impact of magmatism on petroleum systems in the Sverdrup Basin,
Canadian Arctic Islands, Nunavut: A numerical modelling study. Journal of Petroleum Geology 30, 237-255.

Kavanagh, J. L., Menand, T., Sparks, R. S. J., 2006. An experimental investigation of sill formation and propagation in layered elastic media. Earth and Planetary Science Letters 245, 799-813.

Kerr, A. D., Pollard, D. D., 1998. Toward more realistic formulations for the analysis of laccoliths. Journal of Structural Geology 20, 1783-1793.

Larsen, H. C., Marcussen, C., 1992. Sill-intrusion, flood basalt emplacement and deep crustal structure of the Scoresby Sund region, East Greenland. In: Storey, B. C., Alabaster, T., Pankhurst, R. J. (eds.), Magmatism and the Causes of Continental Break-up. Geological Society Special Publications 68, 365-386

Lister, J. R., Kerr, R. C., 1991. Fluid-mechanical models of crack-propagation and their application to magma transport in dykes. Journal of Geophysical Research - Solid Earth and Planets 96, 10049-10077.

Logan, D. L., 2002. A First Course in the Finite Element Method. Brooks/Cole, Pacific Grove, USA.

Maes, S. M., Tikoff, B., Ferré, E. C., Brown, P. E., Miller Jr., J. D., 2007. The Sonju Lake layered intrusion, northeast Minnesota: Internal structure and emplacement history inferred from magnetic fabrics. Precambrian Research 157, 269-288.

Malthe-Sorenssen, A., Planke, S., Svensen, H., Jamtveit, B., 2004. Formation of saucer-shaped sills. In: Breitkreuz, C., Petford, N. (eds.), 2004. Physical Geology of High-Level Magmatic Systems. Geological Society of London Special Publications 234, 215-227.

Mudge, M. R., 1968. Depth control of some concordant intrusions. Geological Society of America Bulletin 79, 315-332.

Mutter, J. C., Carbotte, S. M., Su, W. S., Xu, L. Q., Buhl, P., Detrick, R. S., Kent, G. M., Orcutt, J. A., Harding, A. J., 1995. Seismic images of active magma systems beneath the 
East Pacific Rise between 17-Degrees-05' and 17-Degrees-35'S. Science 268, 391-395.

Németh, K., Martin, U., 2006. Shallow sill and dyke complex in western Hungary as a possible feeding system of phreatomagmatic volcanoes in "soft-rock" environment. Journal of Volcanology and Geothermal Research 159, 138-152.

Oddson, B., 1984. Geology and Geotechnical Behaviour of the Young Volcanic Rocks of Iceland with Emphasis on the Effects of Petrography. Ph. D. Thesis, ETH Zürich, Zürich (in German).

Palmer, H. C., Ernst, R. E., Buchan, K. L., 2007. Magnetic fabric studies of the Nipissing sill province and Senneterre dykes, Canadian Shield, and implications for emplacement. Canadian Journal of Earth Sciences 44, 507528.

Pollard, D. D., Johnson, A. M., 1973. Mechanics of growth of dome laccolithic intrusions in Henry Mountains, Utah. 2. Bending and failure of overburden layers and sill formation. Tectonophysics 18, 311-354.

Roberts, J. L., 1970. The intrusion of magma into brittle rocks. In: Newall, G., Rast, N. (Eds.). Mechanism of Igneous Intrusion. Journal of Geology Special Issue 2, 287-238.

Rocchi, A., Westerman, S., Innocenti, F., Dini, A., Tonarini, S., 2002. Two-stage growth of laccoliths at Elba Island (Italy). Geology 30, 983-986.

Ryan, M.P., 1993. Neutral buoyancy and the structure of mid-ocean ridge magma reservoirs. Journal of Geophysical Research 98, 2232122338.

Shirley, D. N., 1987. Differentiation and compaction in the Pallisades sill, New Jersey. Journal of Petrology 28, 835-865.

Singh, S. C., Crawford, W. C., Carton, H., Seher, T., Combier, V., Cannat, M., Canales, J. P., Dusunur, D., Escartin, J., Miranda, J. M., 2006. Discovery of a magma chamber and faults beneath a Mid-Atlantic Ridge hydrothermal field. Nature 442, 1029-1032.

Sinton, J. M., Detrick, R. S., 1992. Midocean ridge magma chambers. Journal of Geophysical Research - Solid Earth 97, 197-216.

Spence, D. A., Turcotte, D. L., 1985. Magmadriven propagation of cracks. Journal of Geophysical Research 90, 575-580.

Thomson, K., Hutton, D., 2004. Geometry and growth of sill complexes: insights using 3D seismic from the North Rockall Trough. Bulletin of Volcanology 66, 364-375.

Upton, B. G. J., Rämö, O. T., Heaman, L. M., Blichert-Toft, J., Kalsbeek, F., Barry, T. L., Jepsen, H. F., 2005. The Mesoproterozoic ZigZag Dal basalts and associated intrusions of eastern North Greenland: mantle plumelithosphere interaction. Contributions to Mineralogy and Petrology 149, 40-56.

Valentine, G. A., Krogh, K. E. C., 2006. Emplacement of shallow dikes and sills beneath a small basaltic volcanic center - The role of pre-existing structure (Paiute Ridge, southern Nevada, USA). Earth and Planetary Science Letters 246, 217-230.

Vigneresse, J-.L., Tikoff, B., Améglio, L., 1999. Modification of the regional stress field by magma intrusion and formation of tabular granitic plutons. Tectonophysics 302, 203-224.

Walker, G. P. L., 1989. Gravitational (density) controls on volcanism, magma chambers and intrusions. Australian Journal of Earth Sciences 36, 149-165.

Williams, H., McBirney, A.R., 1979. Volcanology. Freeman, San Francisco.

Zienkiewicz, O. C., 1977. The Finite Element Method. McGraw-Hill, New York. 
This chapter has been submitted to Bulletin of Volcanology as:

Burchardt, S. \& Walter, T. R. Miyakejima caldera collapse simulated in experiments: digital image correlation analyses reveal Caldera ring-fault propagation, linkage, and interaction. Submitted to Bulletin of Volcanology.

4. Miyakejima caldera collapse simulated in experiments: digital image correlation analyses reveal Caldera ring-fault propagation, linkage, and interaction

\begin{abstract}
The formation of ring faults yields important implications for understanding the structural and dynamic evolution of collapse calderas and associated ash-flow eruptions. A show-case of a caldera collapse occurred in 2000 at Miyakejima Island (Japan) in response to a lateral intrusion that triggered successive upward propagating ring faulting and partial fault linkage. To understand the kinematics of ring-fault propagation, linkage, and interaction, we describe new laboratory sand-box experiments that were analysed through Digital Image Correlation (DIC) and post-processed using 2D strain analysis. The results help to gain a better understanding of the processes that led to caldera collapse in Miyakejima Volcano by showing that magma chamber evacuation induces strain localisation at the lateral chamber margin in form of a set of reverse faults that sequentially develops and propagates upwards. Then a set of normal faults initiates from new tension fractures at the surface and propagates downwards to interlink with the reverse faults at depth. With increasing amount of subsidence, interaction between the reverse- and normal-fault segments results in a deactivation of the reverse faults, while displacement becomes focused on the outer normal faults. Hence, simulated collapse migrates successively outward, as peak displacement transfers from the inner ring faults to later-developed outer ring faults. The final structural architecture of the faults bounding the subsiding piston-like block is hence proportional to the amount of subsidence, and in agreement with many caldera structures observed in nature. These experimental results provide an analogy to the observations and seismic records of caldera collapse in Miyakejima Volcano.
\end{abstract}

\title{
4.1 Introduction
}

Collapse calderas are kilometre-scale magma chambers (Williams, 1941). volcanic depressions bordered by ring faults Evacuation may be due to lateral intrusion that form during the evacuation of crustal into the host rock or due to upward 
eruption, initiating subsidence of the magma-chamber roof and caldera floor (Smith and Bailey, 1968). However, conceptual models that link eruption dynamics and caldera subsidence strongly depend on a clear understanding of the structural evolution of calderas including the activity and development, i.e., propagation, interaction, and linkage, of near-surface and underground faults.

Caldera volcanoes exist in nearly all tectonic settings (Newhall and Dzurisin, 1988), and are associated with the largest explosive eruptions known on Earth (Druitt and Sparks, 1984) that can exceed a VEI of 7 (e.g. the caldera formation in Toba (74 ka), Yellowstone (640 ka), and Long Valley (760 ka)). In silicic explosive calderas, magma injection along ring faults actively influences the mechanism of ringfaulting and successive collapse. Fracturing and dyke injection during inflation phases of the magma reservoir prior to caldera formation emplace additional structural controls on the formation of ring faults and their dynamics during collapse. In the last 100 years explosive eruptions at calderas were considered of moderate size; only less than 5\% reached a VEI greater 4 (Newhall and Dzurisin, 1988). In addition, calderas form in Hawaiian-type basaltic volcanoes, where collapse is not necessarily associated with eruptions (e.g. Mauna Loa, Fernandina, Piton de la Fournaise, and Miyakejima). In general, larger historical eruptions have been mainly controlled by the structural conditions of a pre-existing caldera and included the reactivation and intrusion of existing ring faults. The temporal evolution and geometric architecture of these ring faults, however, remained unclear.

The caldera collapse associated with the 2000 Miyakejima lateral dyke intrusion and magma chamber deflation is probably the best instrumentally recorded caldera formation. Deformation and seismicity records, and well as observations of eye witnesses, allow a detailed investigation of the chronology of events, showing sequentially upward propagating faults and depression widening near the surface (Geshi et al., 2002; Nakada et al., 2005). In this paper, we therefore first give a brief description of the progression of caldera formation at Miyakejima. Then we compare it with the results of laboratory simulations analysed with a digital image correlation technique. The experiments give sub-millimetre deformation time-series and provide new insights into the variable propagation and linkage of ring faults revealing the structural complexity of calderas in basaltic volcanoes.

\subsubsection{The Miyakejima caldera-collapse sequence}

The most recent caldera collapse occurred on Miyakejima Island, which is a $9 \mathrm{~km}$ wide, $815 \mathrm{~m}$ high inhabited island located to the southeast of Honshu, Japan. Volcanic activity on Miyakejima has been observed frequently, as in 1874, 1940, 1962, and 1983. The island's morphology has been shaped by repeated explosive eruptions, some associated with caldera 
collapse (e.g. 2500 yrs ago) and also effusive fissure eruptions on the flanks. In summer 2000 a new, $1.7 \mathrm{~km}$ wide caldera developed in the summit of Miyakejima Volcano, the floor of which subsided to a depth of just $250 \mathrm{~m}$ above sea level. a "butterfly" pattern and could be explained by stress transfer in the shallow crust (Toda et al., 2002). Dyke intrusion resulted in drainage of the magma reservoir underlying the volcano (Figure 4.2) that was estimated to be at a depth of 4 to 5
A) Seismicity prior to caldera collapse

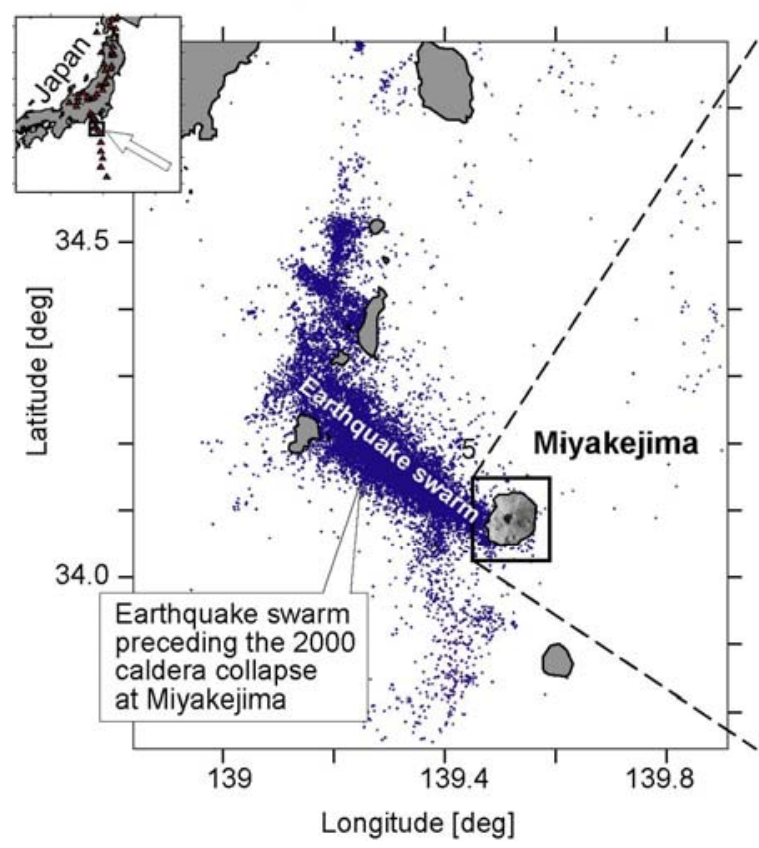

B) Sequential caldera collapse and widening
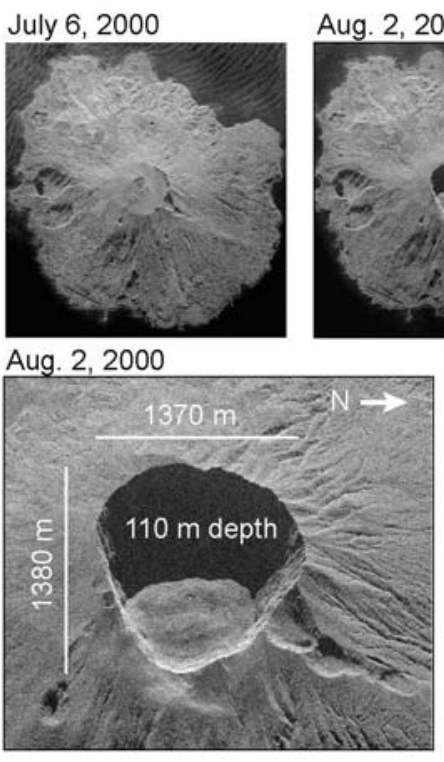

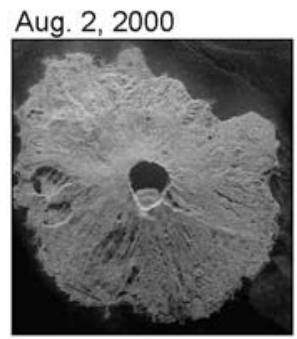

Aug. 30,2000

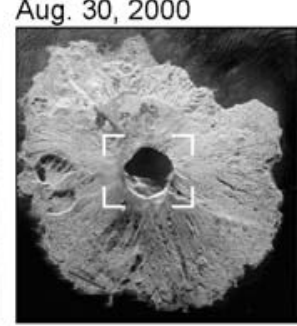

Aug. 30,2000

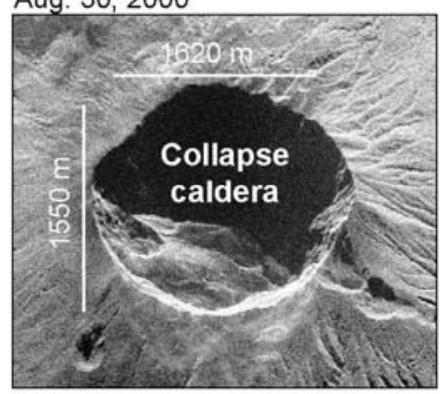

Figure 4.1. A) Distribution of seismic events preceding the 2000 caldera collapse on Miyakejima Island, Japan (Toda et al., 2002; data from ERI, Earthquake Research Center, University of Tokyo). The earthquake swarm migrating offshore from Miyakejima to the $N W$ was related to dyke injection (Yamaoka et al., 2005). B) SAR images of the formation of a collapse caldera in the summit of Miyakejima Island, Japan, in 2000. Only two weeks after deflation of the magma chamber started, did ring-fault propagation, which before had been detected by seismicity, reach the surface. As a result, a small caldera formed on July 28. This caldera widened considerably during continuing subsidence by the formation of peripheral normal faults. Images provided by Japanese National Institute of Information and Communications Technology (NICT), 2007.

The 2000 Miyakejima caldera-collapse sequence started in the end of June with seismicity increase and deformation tens of kilometres northwest of Miyakejima Island. The seismicity pattern as shown in Figure 4.1 is thought to have been related to dyke intrusion away from Miyakejima Volcano, with an aftershock sequence that resembled km below sea level (Furuya et al., 2001; Nakada et al., 2001). In the beginning of July a columnar earthquake swarm with a diameter of $2 \mathrm{~km}$ (Sakai et al., 2001) initiated beneath the summit characterised by continuous upward propagation and an increase in magnitude of the seismic events (Figure 4.3). On 8 July slight flexural 
subsidence of the summit of Miyakejima Volcano transformed into the collapse of a caldera. The surface expression of the caldera was thus delayed with respect to drainage of the underlying reservoir (Figure 4.1B), which was explained by successive upward fault propagation and underground collapse before reaching the surface (Walter and Troll, 2001; Geshi et al., 2002).
According to Geshi et al. (2002), the newly formed caldera consisted of a central piston, $300 \mathrm{~m} \times 500 \mathrm{~m}$ large, surrounded by a concentric array of tension fractures and normal faults with an overall diameter of $1 \mathrm{~km}$. After two days of subsidence the caldera depression had reached a depth of $300 \mathrm{~m}$. During the following month the diameter of the caldera depression constantly increased to a final diameter of
$1.6 \mathrm{~km}$, accompanied by the occurrence and retreat of new faults at the surface and associated with slumps of large blocks into the depression. Due to the gravitational collapse of the caldera wall, the depth of the depression remained
Figure 4.2. Chronology of the events related to caldera collapse in Miyakejima Volcano according to Geshi et al. (2002) and Nakada et al. (2005). An intrusion stage in the beginning led to the injection of a dyke and a submarine eruption (marked by dark grey star) to the $N W$ of the volcano. This was followed by a caldera collapse that was only since 10 August accompanied by stronger explosive activity (indicated by light grey stars). Since the end of August activity switched to strong degassing from the summit of Miyakejima.

Caldera collapse was associated with explosive eruptions that occurred during the following month with climax on 18 August 2000 and that migrated from the centre of the newly-formed caldera to its margin (Geshi and Oikawa, 2008). constant $(450 \mathrm{~m})$ from the middle of July on. However, the effective subsidence was between 1.6 and $2.1 \mathrm{~km}$; thus the original caldera floor even subsided to a depth below sea level.

\subsubsection{Structural architecture of ring faults} In spite of these detailed observations on Miyakejima Island, the geometric evolution and kinematics of ring-faults including fault propagation and interaction is still incompletely understood. Even after years of vigorous debate is there not even a consensus on the question whether caldera faults at Miyakejima and elsewhere are inward- or outward-dipping (e.g., Gudmundsson and Nilsen, 2006; Acocella, 2007). New eruptions may initiate from 
faulting of magma-chamber roofs, such as hypothesised for Miyakejima. Thus, the propagation direction of ring faults as well as the interaction between ring faults are of major importance for understanding syncollapse eruption locations and vent dynamics (e.g. Geshi and Oikawa, 2008; Holohan et al., 2008); syn-collapse magmachamber dynamics (Kennedy et al., 2008); conduit widening; as well as sites for postcollapse volcanism (e.g. Saunders, 2001), geothermal activity (e.g. Goff et al., 2000), and mineralisations (e.g. Stix et al., 2003).
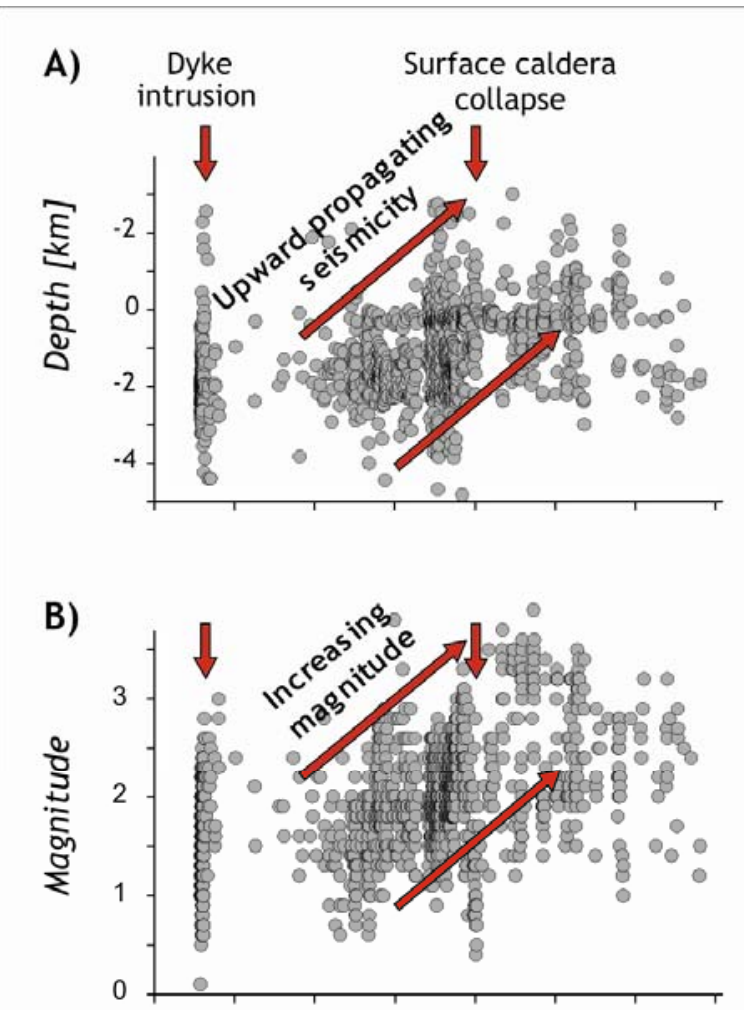

C)

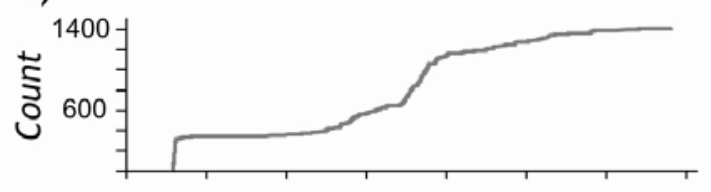

D)

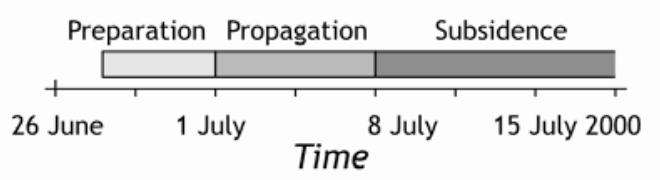

Laboratory experiments on caldera formation above a deflating magmachamber analogue (see recent reviews by Cole et al., 2005; Acocella, 2007, 2008; Marti et al., 2008; and references therein) suggest that caldera collapse generates two sets of ring structures - outward-dipping reverse ring faults enclosed by inwarddipping normal faults (cf. Appendix A1).

Figure 4.3. Seismic activity at Miyakejima Island (beneath the summit) associated with the caldera collapse in 2000. Data from Sakai et al. (2001). A) The depth distribution of epicenters shows a distinct upwards propagation with time after the dyke intrusion in the end of June. B) The magnitude of earthquakes increased with time before caldera collapse. C) After dyke intrusion $N W$ of Miyakejima Island the number of seismic events increased strongly until shortly before caldera collapse. Note that not all seismic events have been picked due to their great number and since smaller events on Miyakejima Island were often overlain by larger events offshore (T. Ohminato, personal communication 2008). D) The temporal and spatial distribution of seismicity is characterised by a multi-phase pattern that can be divided into (1) a Preparation Phase with very low seismic activity; (2) a Propagation Phase with high seismic activity migrating upwards; and (3) a Subsidence Phase with moderate seismicity without clear migration. 
Field and geophysical data, however, suggest various ring-fault architectures: outward- and inward-dipping ring faults are evident at Rabaul, Papua New Guinea (Mori and McKee, 1987), whereas the caldera collapse at Fernandina, Galapagos, in 1968 apparently occurred along inwarddipping ring faults (Simkin and Howard, 1970), a configuration also known from eroded calderas in the Western USA (Lipman, 1984). While inward-dipping ring faults may cause a "space problem" during subsidence and may prohibit major conduit opening (Branney, 1995), outward-dipping faults are rarely observed at the surface due to landslide processes (Lipman, 1984). In some caldera systems, contemporaneous sub-parallel ring faults appear to provide magma pathways as e.g. at Deception and Rabaul (Newhall and Dzurisin, 1988) implying that the faults progressively develop and that at times more complex configurations of ring faults may be active. In order to better understand the structural and temporal evolution of caldera subsidence in Miyakejima and other basaltic volcanoes, and clarify the link between surface expression and deep structural framework of calderas, we present new experimental results analysed with the aid of a high-resolution digital recording technique. Results display the dynamic evolution of ring-fault formation, propagation and interaction, as detailed in the next section.

\subsection{Analogue experiments}

\subsubsection{Experimental setup and scaling}

We follow previous experimental investigations by e.g. Roche et al. (2000), simulating caldera subsidence and shear localization in a granular material that approaches a Mohr-Coulomb friction law (Schellart, 2000). New results are achieved through the application of a digital image correlation (DIC) technique that allows strain studies with spatial and dynamic resolutions in sub-millimetre and microstrain range, respectively (Adam et al., 2005). A digital monochrome CCD (charge-coupled device (digital)) camera was used to acquire images at high resolution (12 megapixels). Calculation of displacements at accuracies $<0.1$ pixels (White et al., 2001) were achieved by the application of a multi-pass cross correlation algorithm (LaVision, 2002), allowing to compare successive images. We compare the particle distribution of two subsequent images in order to derive the deformationvector field and the strain field in each granular flow experiment (Figure 4.4). For the adopted distance to the experiment box and camera parameters, we obtained spatial resolutions of about $0.2 \mathrm{~mm}$ and a temporal resolution between successive images of $5 \mathrm{~Hz}$. More details about the DIC method are provided in the Electronic Supplementary Material.

The experiments were performed in a sand box, and cross-sectional development could be investigated through two glass panes set up at a distance of $10 \mathrm{~cm}$ (Figure 4.4). To 
simulate reservoir deflation, we used a retractable piston with an area of $10 \mathrm{~cm} \times$ $10 \mathrm{~cm}$ emplaced within a cut-out of the same size in the basal plate. In the beginning of the experiment, the piston was located at the level of the basal plate, which was overlain by the analogue crustal material. Through a computer-controlled motor, we defined piston retraction at a subsidence rate of $0.015 \mathrm{~cm} \mathrm{~s}^{-1}$ for $120 \mathrm{~s}$, accumulating to a total subsidence of 1.8 cm. In systematic experimental tests, we varied the chamber depth to evaluate the influence of the roof aspect ratio $(\mathrm{AR}=$ depth/thickness of the chamber roof vs. diameter of the chamber), which ranged from 0.41 to 3.01 in eleven individual experiments and is described in Section 4.2.2. This AR range also covers the geometric configuration of the Miyakejima caldera system, to which the results are compared in Section 4.2.3.

A)

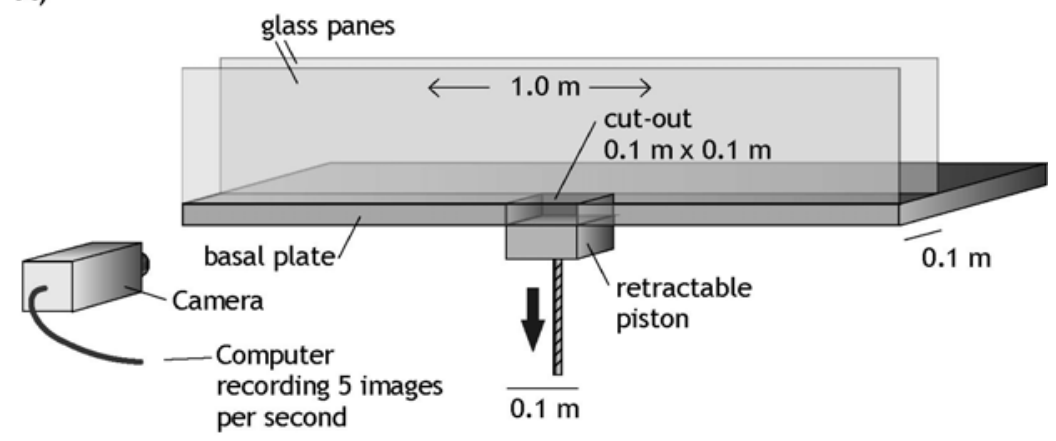

B)

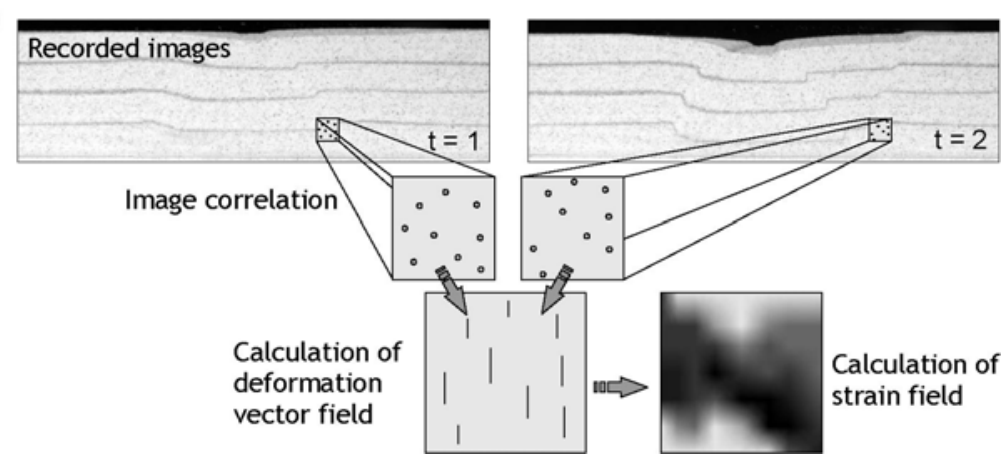

The experiments were geometrically and dynamically scaled (cf. Hubbert, 1937; Sanford, 1959) to fit the configuration of natural calderas regarding roof aspect ratio and subsidence. The geometric scaling factor was $2.5 \times 10^{-5}$, so that $1 \mathrm{~cm}$ in the experiments corresponds to approximately $400 \mathrm{~m}$ in nature. As a crustal analogue material, we used a 1:5 mixture of wheat starch (cf. Donnadieu and Merle, 1998) and dry quartz sand (Cobbold and Castro, 1999). We determined the coefficient of internal friction $\mu_{\mathrm{F}}$ for the starch-sand mixture with the ring shear test; the angle of internal friction $\varphi_{\mathrm{F}}$ is $\sim 28^{\circ}$ and thus comparable to natural systems. The natural cohesion of crustal materials is in the range of $10^{5}$ to $10^{7} \mathrm{~Pa}$ (e.g. Hoshino et al., 1972), while the cohesion of the analogue material is $70 \mathrm{~Pa}$. Considering a scaling factor of $2.5 \times 10^{-5}$, cohesion in our experiments is thus properly scaled.

Figure 4.4. A) Schematic sketch of the experimental setup. The space between the two glass panes was filled to different depth with a mixture of starch and sand to simulate different roof aspect ratios. The piston was retracted $1.8 \mathrm{~cm} . \quad B)$ Schematic sketch of the Digital Image Correlation (DIC) method adapted from http://www.lavision.de 
A comparison of experiments with pure sand and the mixed sand-starch material showed similarly oriented structures, although the structural resolution obtained in the sand-starch mixture is considerably higher and provides additional details. Details of ring-shear granular material tests and the scaling procedure are provided in Section 4.6.2.

Time-dependent viscosities of the magma analogue were not considered in these experiments since we focused our investigation on brittle fracturing only. Other limitations of our experiments may be based on the simplified geometry, rheology, and side effects. The subsiding magma chamber roof is simulated by a retracting undeformable piston, and subsidence occurred along panes of glass. We note however, that the chamber geometry is in agreement with plutons that are often nearly flat-roofed (e.g. Pitcher, 1993, Zak and Paterson, 2006), and our results broadly mimic those of other studies, yielding geometric similarity even though different materials and apparatus were used (cf. Acocella, 2008).

\subsubsection{Digital image processing results}

From the DIC analysis of the individual experiments, we reconstructed a temporal sequence of fault propagation and interaction. Each experiment simulated up to $\sim 700 \mathrm{~m}$ of subsidence in nature. About 600 successive digital images were recorded for each experiment and postprocessed in order to constrain the structural evolution in detail. A photo sequence showing the computed fault initiation, propagation, and interaction is illustrated in Figure 4.5 for a magma chamber roof aspect ratio (AR, ratio depth-to-width) of $\mathrm{AR}=0.6$, and in Figure 4.6 for a roof aspect ratio of $\mathrm{AR}=$ 1.54. Supplementary movies of the experiment development are provided in Section 4.6.5 and the Electronic Supplementary Material.

For $\mathrm{AR}<1$, first shear zones appear at depth after a subsidence of $<0.2 \mathrm{~cm}(\sim 80 \mathrm{~m}$ in nature). A first set of outward-dipping reverse faults initiates underground at the sides of the retracting piston (Figure 4.5A). These reverse faults propagate in tandem upwards and reach the surface at outwarddips of $\sim 50^{\circ}$ near the surface and $80^{\circ}$ at depth. When they reach the surface after $\sim 0.2 \mathrm{~cm}(\sim 80 \mathrm{~m}$ in nature) of subsidence, a second, steeper reverse-fault set forms and propagates upward, while the first set of faults becomes inactive. Then in the caldera periphery, extension fractures commence to propagate downwards and develop into inward-dipping normal faults (Figure $4.5 \mathrm{H}-\mathrm{I}$ ). After subsidence of $\sim 0.6$ to $0.7 \mathrm{~cm}(\sim 250 \mathrm{~m}$ in nature) these peripheral normal faults interlink with the reverse faults at depth (Figure 4.5J). This fault linkage affects the activity of the former dominant reverse faults: they become inactive for most of the ensuing experiment duration until $1.8 \mathrm{~cm}$ of subsidence and the end of the experiment is reached. Occasionally near-surface segments of the reverse ring-fault reactivate for a short duration. Hence, subsidence larger than 0.7 
$\mathrm{cm}$ is accommodated by displacement along faults that are inward-dipping near the surface and subvertical to steeply outward-dipping at depth (Figure 4.5L).

followed by a second, outer set that is more steeply-dipping. As this set localises, displacement begins to transfer from the first set to the second. With around $0.3 \mathrm{~cm}$ of vertical subsidence, accommodation of displacement is entirely transferred to the outer reverse faults, while the inner faults die. Then normal faults propagate downward and link with the reverse faults at depth $\Delta=4.39$ $\mathrm{cm}(K)$. Further subsidence results in the transfer of the displacement along the normal faults combined with the lower part of the reverse faults. The upper parts of the reverse faults only stay sporadically active. Dashed lines in B) and L) illustrate deflection profile of the model surface, while arrows display the limit of

Figure 4.5. Sequence of pictures displaying the rotational strain (rotation around the horizontal z-axis) in experiment no. 2D_15-110 with a roof aspect ratio of 0.6. Subsidence is given in $\mathrm{cm}$. The sequence of ring-fault evolution starts with an upward propagation of a first set of moderately-dipping reverse faults influence of caldera subsidence at the surface $(11.7 \mathrm{~cm}$ in $B)$ and $15.0 \mathrm{~cm}$ in L)). Displacement transfer between faults is marked by asterisks. For full videos of experiment 2D_15-110, see Section 4.6.5 and Electronic Supplementary Material. 
For roof aspect ratios $>1$, faulting is initially asymmetric with a laterally alternating propagation and activity of individual faults (Figure 4.6), developing at larger number and different scales compared to low-AR calderas.

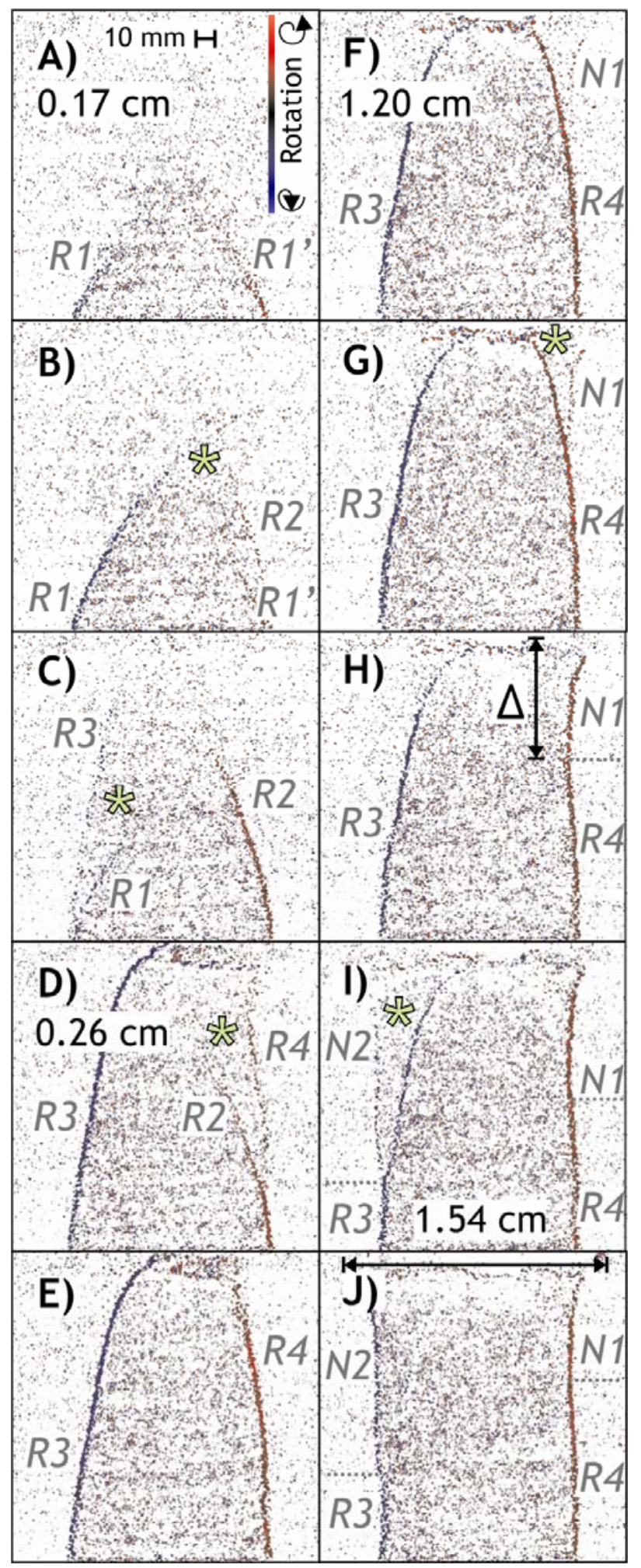

Figure 4.6. Sequence of pictures displaying the rotational strain (rotation around the horizontal z-axis) in experiment no. 2D_15-118 with a roof aspect ratio of 1.54. Subsidence is given in cm. Subsidence is accommodated by a complex sequence of ring-fault evolution: $A$ ) Reverse faults $R 1$ and R1' propagate from the chamber roof upwards and meet at the vertical mid-line of the roof (roof centre). B) R2 localises and propagates upwards until it reaches the roof centre. Displacement transfers from R1' to R2. C) R1' dies, as R2 now takes up all displacement on the model right side. $R 3$ localises and propagates to the roof centre. Displacement begins to transfer from $R 1$ to $R 3$. $D) R 3$ reaches the model surface. $R 1$ has died, as $R 3$ takes up all displacement on the model left side. $R 4$ begins to propagate upward on the right side. Displacement begins to transfer from $R 2$ to $R 4$. E) $R 2$ is inactive, as all displacement on the model right side is taken up on $R 4$, while all left side displacement is taken up on R3. F)-H) Normal fault N1 propagates downwards and links with $R 4$ at a depth $\triangle$ of 6 $\mathrm{cm}$. Then the upper part of $R 4$ deactivates as near-surface displacement transfers to N1. However, the lower part of $R 4$ remains active. I) \& J) N2 localises and links with $R 3$. Displacement transfers from the upper part of $R 3$ to N2, while the lower part of $R 3$ remains active. Thus, the final ring-fault configuration is a combination of the lower parts of earlier reverse faults and the later-formed normal faults. The arrow in J) displays the limit of influence of caldera subsidence at the surface $(=13.2 \mathrm{~cm})$. For full video of experiment 2D_15-118, see Section 4.6.5 and Electronic Supplementary Material. 
The period of downsag observed at the surface lasts up to $\sim 0.26 \mathrm{~cm}$, during which a sequence of faulting occurs beneath the surface. First reverse faults develop near the magma-chamber margin at about 0.1 $\mathrm{cm}$ of subsidence in a symmetric fashion (similar as in $\mathrm{AR}=0.6$ experiment; Figure 4.6A-B). Then a second, steeper reverse fault develops on one side of the chamber roof (here to the right of the magma chamber; Figure 4.6B) and propagates upwards to the centre of the magma chamber roof. When another fault on the opposite side of the chamber (here to the left) develops, displacement transfers from the second to the newly formed fault (Figure 4.6D). This is the first fault that reaches the surface with a dip of about $30^{\circ}$, increasing to $45^{\circ}$ in the upper part of chamber roof and then steepening to $70^{\circ}$ for most of the fault length down to its base at the chamber side. Further sets of faults may develop in alternating pattern and broaden the structural caldera diameter at the surface. However, in general, the simultaneous activity of two successive reverse-fault pairs on each side of the magma chamber is always very short-lived so that displacement is most of the time focused on one reverse-fault pair. With about $1.2 \mathrm{~cm}$ of subsidence (Figure $4.6 \mathrm{~F}$ ) first inward dipping faults develop at the caldera periphery. A clear propagation direction, however, is not unambiguously recognizable, thus the periphery faults appear to localise contemporaneously on their entire length. Immediately after interlinkage of the normal and reverse ringfault segments, the upper parts of the outward-dipping faults become inactive (Figure 4.6I-J). However, at higher subsidences, they can sporadically become reactivated allowing faulting in the upper part of the subsiding roof.

Thus the experiments reveal complexly propagating and interacting ring faults that develop sequentially and may explain many of the chronologic and geometric patterns observed on Miyakejima during the 2000 caldera collapse.

\subsubsection{Comparison of experimental} structures to Miyakejima chronology

The 2000 Miyakejima collapse is probably the best instrumentally recorded calderaforming event, since it was observed in detail at the surface and monitored with seismicity, as well as other geophysical methods. Seismic activity below the summit was distributed in a $2 \mathrm{~km}$ wide, columnar swarm, the top of which migrated to shallower depths (Figure 4.3; Propagation Phase), while the summit of Miyakejima was initially deflating before caldera collapse occurred at the surface on 8 July. Based on the collected data, Geshi et al. (2002) developed a conceptual model for the structural evolution of the collapse caldera including the seismic upwardpropagation of reverse ring faults.

The experimental results presented by us bear a striking resemblance to the model by Geshi et al. (2002), but with their detailed information about the kinematics of ring-fault evolution, they can contribute 
considerably to an understanding of what happened before and during the summit of Miyakejima collapsed in July and August 2000 .
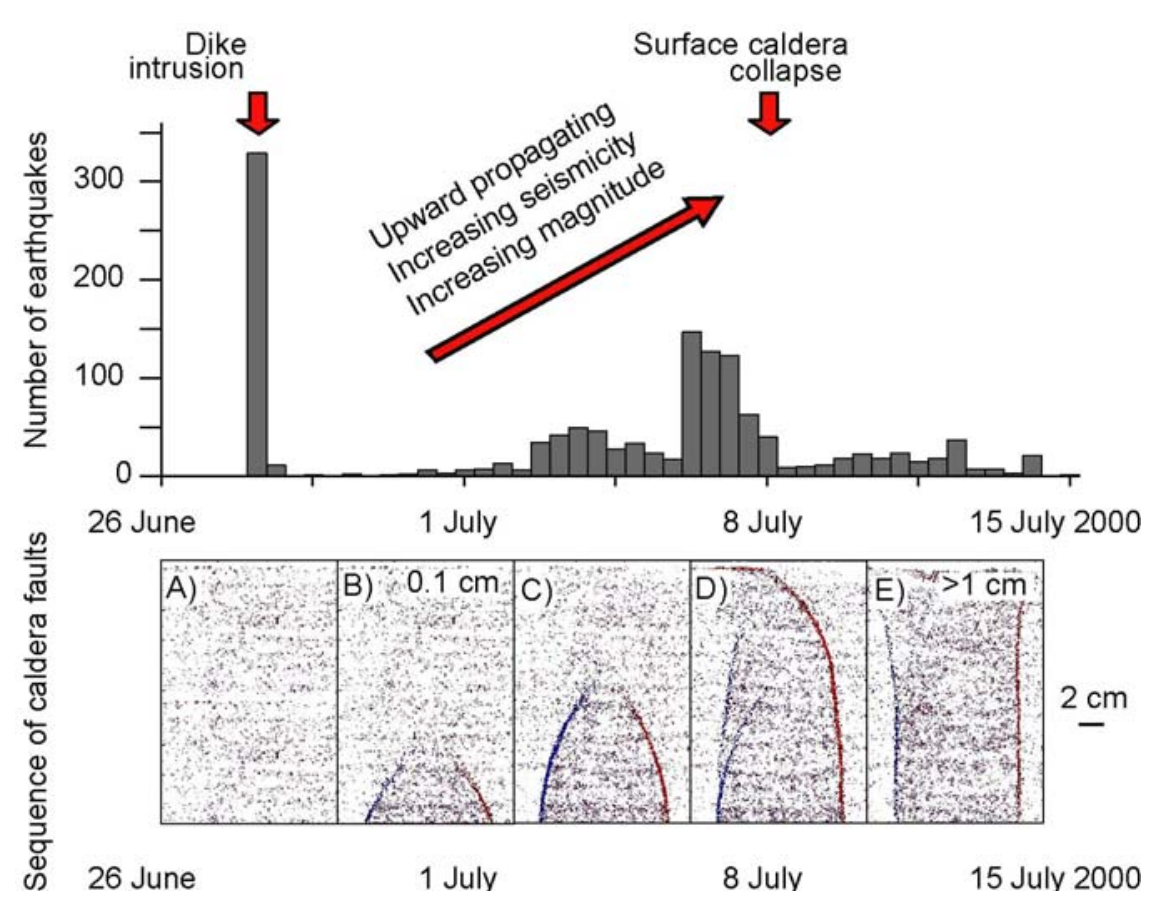

$\mathrm{km}$. The diameter of the caldera at surface is $1.6 \mathrm{~km}$, whereas the seismic trace of the subsiding piston had a diameter of $2 \mathrm{~km}$ (Geshi et al., 2002). Assuming that the size of the piston corresponds to the size of the magma reservoir, the resulting aspect ratio is 2 to 3.1 . For the same range we performed also experiments. Figure 4.7 provides an example for a roof aspect ratio of $\mathrm{AR}=2.01$ compared to the time progression of seismic events at Miyakejima. Although the subsidence at Miyakejima (>40 mm when scaled down) would exceed the subsidence in our experiments and we neglected the influence of topography, there are clear analogies between our experimental results and caldera collapse at Miyakejima. Especially for the Propagation Phase of seismicity (cf. Figure 4.3D), our experimental results provide valuable insights into ring-fault kinematics. Similar to the upward-directed propagation of seismicity observed in nature (Figure 4.3A), our scaled Miyakejima experiments are characterised by more than three sets of reverse faults that progressively propagate to shallower depths so that surface collapse only occurs after subsidences of $4 \mathrm{~mm}$ for $\mathrm{AR}=2.01$ and $7.3 \mathrm{~mm}$ for $\mathrm{AR}=3.01 \quad(\sim 160 \mathrm{~m}$ and $\sim 290 \mathrm{~m}$ in nature, respectively) and is hence delayed in comparison to magma-
The effective subsidence achieved during the 40 days of caldera formation was 1.6 to $2.1 \mathrm{~km}$. According to GPS data by Ueda et al. (2005) and gravity data by Furuya et al. (2001), the depth of the magma reservoir underlying Miyakejima was 4 to 5 
chamber deflation (cf. Walter and Troll, 2001; Geshi et al., 2002; Nakada et al., 2005). In addition, our experimental results indicate that with increasing subsidence, larger faults are active and propagate over longer time. This may explain why largest earthquake-energy releases did not occur at initial caldera stages, but the magnitude rather increased during the Propagation Phase on Miyakejima (Fig. 4.3). After ring faults have connected to the surface in the experiments, the fault configuration of the inner reverse ring faults remains nearly stable. This probably explains why, after surface collapse in Miyakejima occurred, seismicity magnitudes do not show any distinct changes any more (Subsidence Phase; Figure 4.3). Furthermore, the experiments show that with increasing subsidence, displacement transfers from inner reverse ring faults to newly-formed outer normal ring faults (Figs. 4.5-4.7). Analogously, the structural diameter of the caldera at the surface increases successively as was observed for the 2000 caldera of Miyakejima, which grew from a diameter of $1 \mathrm{~km}$ in the beginning of summit collapse on 8 July to $1.6 \mathrm{~km}$ in the middle of August (Fig. 4.1). In the case of Miyakejima, the increase of the caldera diameter was, however, primarily a consequence of landslide processes rather than of the retreat of the peripheral normal ring-fault, since immediately after the first surface caldera formed, normal and reverse ring faults were already active (cf. Geshi et al., 2002). Furthermore, our experimental results provide a possible explanation for vent migration and the location of geothermal activity during Miyakejima caldera collapse. According to Geshi and Oikawa (2008), first phreatomagmatic eruptions at the beginning of collapse occurred near the caldera centre, whereas subsequent eruptions took place at the marginal area of the caldera. In addition, geothermal activities in the post-caldera stage concentrate along the rim of the caldera floor. Displacement transfer from inner reverse ring faults that first reach the surface near the centre of the later caldera to outer ring faults accompanied by the inactivation of the earlier ring faults, as observed during the experiments, offers a possible explanation for these observations.

\subsection{Discussion}

General implications that arise from our experimental results include that the structural system of collapse calderas encompasses several sets of outwarddipping reverse faults, the number of which depends on the roof aspect ratio of the magma chamber, and steeply inwarddipping, peripheral normal faults. This configuration is known from numerous geological, geochemical and geophysical studies (e.g. Smith and Bailey, 1968; Lipman, 1984; Roche et al., 2000). Recent experimental studies, however, disclose that development and propagation direction of caldera ring-faults is unclear and contradicting (Geyer et al., 2006; Marti et al., 2008; Acocella, 2008 and references therein; see also Section 4.6.1). 
In addition to what is known from earlier analogue experiments of caldera collapse, Digital Image Correlation (DIC) analyses of the experiments presented in this paper demonstrate the possibility to quantify the kinematics of ring-fault formation, propagation, and interaction. Furthermore, we show how the inward- and outward-dipping ring faults interlink and help to clarify previously accepted models of the process of ring-fault propagation and interaction. All our models show that the outwarddipping faults initiate at the margins of the magma chamber and propagate in tandem (for low AR) or in alternating sequence (high AR) upwards. This may be due to the increasing influence of small mechanical heterogeneities for high-AR caldera setups. In later stages, the inwarddipping ring faults initiate from surface extension fractures that transform into mode II shear fractures and propagate downwards. Interaction including displacement transfer and inactivation of fault segments as well as linkage occurs between the normal faults and the earlier reverse ring fault; this is considered to be the final structural stage which accomplishes most of the successive subsidence.

Furthermore, our observation that caldera ring-faults develop in a continuous sequence according to which they initiate, propagate, and become inactive again explains the multifaceted expression of caldera faults, and implies that the initial ring faults in subsiding calderas can be clamped and deactivated, while eruptions may take place along newly-forming sets of peripheral ring faults. This could account for the large widths of many ringdyke complexes, which have previously been explained by stoping (e.g. MacDonald, 1972) but are in fact constructed during fewer events with whole arrays of ring dykes. Magma transport within the upward-propagating ring faults is possible from the very initial stages of subsidence. However, the downwardpropagating peripheral ring faults can only act as magma feeders if they link to the reverse faults at depth. The experiments also suggest that magma transport along the initial ring faults may become inhibited due to their closure. Therefore, the variability of the ring faults during subsidence implies that the location of conduits is variable and progressively tends to propagate outwards, which in turn could explain local stratigraphic discontinuities and inconsistencies. Vent migration, and in some cases vent multiplication during caldera eruptions have been observed e.g. in Valles, Long Valley, Santorini (Druitt, 1986; Self et al., 1986; Holohan et al., 2008). These observations can be interpreted as a consequence of the reconfiguration of the conduit system due to sealing and establishment of magma pathways along a dynamically developing ring-fault system.

In the broader sense, an enhanced understanding of the kinematics of ringfault propagation that can be gained from the experimental results presented above may also contribute to a better comprehension of for instance caldera-collapse 
mechanisms, the eruption and hazard potential of unrest periods in caldera volcanoes (Scandone and Acocella, 2007), magma-chamber dynamics, and the interpretation of geophysical monitoring data of calderas such as e.g. for Miyakejima Volcano in 2000. In addition, the described ring-fault evolution with proceeding subsidence has consequences for the location of post-collapse volcanism (e.g. Sierra Negra, Galapagos, Ecuador (Geist et al., 2008)) and geothermal fields (e.g. Goff et al., 2000; Geshi and Oikawa, 2008), which are preferably located along the traces of the ring faults at the surface (cf. Scandone and Acocella, 2007).

\subsection{Conclusions}

The formation and evolution of ring faults in collapse calderas were analysed in a series of scaled analogue experiments. The results were processed with Digital Image Correlation (DIC) and indicate that magma-chamber deflation entails the following sequential evolution of ring faulting:

o During flexure first outward-dipping faults develop near the magma chamber and propagate upwards in the underground.

o For small aspect ratios (shallow and large chambers) reverse ring faults propagate simultaneously, for high aspect ratios (deep or small chambers) reverse ring faults propagate sequentially. o During continuous subsidence new, steeper-dipping reverse faults form outside the earlier-formed faults and displacement is transferred to the new faults before the earlier ones become inactive. Hence, the structural diameter of the caldera widens.

o Normal faults develop from extension fractures in the zone of maximum extension at the caldera periphery and propagate downwards.

o At depth, the downward-propagating caldera normal-faults start to interact and finally link with the lower segments of the reverse faults. Consequently, the activity of the upper segments of the reverse faults diminishes.

o The final structural expression of a caldera may be bound by inward- or outward- dipping faults, depending on the amount of subsidence and interaction and linkage of both fault types.

Our experimental results provide detailed insights into the dynamics of ring-fault evolution that help to explain field observations and monitoring data of natural caldera volcanoes. The described sequence of ring-fault evolution represents for example a conclusive model for the events leading to the formation of a collapse caldera in Miyakejima Volcano, Japan in 2000. 


\subsection{References}

Acocella, V., 2007. Understanding caldera structure and development: An overview of analogue models compared to natural calderas. EarthScience Reviews 85, 125-160.

Acocella, V., 2008. Structural development of calderas: a synthesis from analogue experiments. In: Gottsmann, J., Marti, J. (eds.), Caldera Volcanism. Analysis, Modelling and Response. Elsevier, Amsterdam, 336 p.

Adam, J., Urai, J. L., Wieneke, B., Oncken, O., Pfeiffer, K., Kukowski, N., Lohrmann, J., Hoth, S., van der Zee, W., Schmatz, J., 2005. Shear localisation and strain distribution during tectonic faulting-new insights from granularflow experiments and high-resolution optical image correlation techniques. Journal of Structural Geology 27, 283-301.

Branney, M. J., 1995. Downsag and extension at calderas: new perspectives on collapse geometries from ice-melt, mining, and volcanic subsidence. Bulletin of Volcanology 57, 303-318.

Cobbold, P. R., Castro, L., 1999. Fluid pressure and effective stress in sandbox models. Tectonophysics 301, 1-19.

Cole, J. W., Milner, D. M., Spinks, K. D., 2005. Calderas and caldera structures: a review. Earth Science Reviews 69, 1-26.

Donnadieu, F., Merle, O., 1998. Experiments on the indentation process during cryptodome intrusions: new insights into Mount St. Helens deformation. Geology 26, 79-82.

Druitt, T. H., 1986. Vent evolution and lag breccia formation during the Cape Riva eruption of Santorini, Greece. Journal of Geology 93, 439454.

Druitt, T. H., Sparks, R. S. J., 1984. On the formation of calderas during ignimbrite eruptions. Nature 310, 679-681.

Furuya, M., Okubo, S., Tanaka, Y., Sun, W., Watanabe, H., Oikawa, J., Maekawa, T., 2001. Caldera formation process at the 2000 Miyakejima volcano detected by spatio-temporal gravity change. Journal of Geography 110, 217 225 (in Japanese with English abstract).

Geist, D. J., Harpp, K. S., Naumann, T. R., Poland, M., Chadwick, W. W., Hall, M., Rader, E., 2008. The 2005 eruption of Sierra Negra volcano, Galapagos, Ecuador. Bulletin of Volcanology 70, 655-673.

Geshi, N., Oikawa, T., 2008. Phreatomagmatic eruptions associated with the caldera collapse during the Miyakejima 2000 eruption, Japan. Journal of Volcanology and Geothermal Research 176, 457-468.

Geshi, N., Shimano, T., Chiba, T., Nakada, S., 2002. Caldera collapse during the 2000 eruption of Miyakejima Volcano, Japan. Bulletin of Volcanology 64, 55-68.

Geyer, A., Folch, A., Martí, J., 2006. Relationship between caldera collapse and magma chamber withdrawal: An experimental approach. Journal of Volcanology and Geothermal Research 157, 375-386.

Goff, F., McMurty, G. M., Counce, D., Simac, J. A., Roldán-Manzon, A. R., Hilton, D. R., 2000. Contrasting hydrothermal activity at Sierra Negra and Alcedo volcanoes, Galapagos Archipelago, Ecuador. Bulletin of Volcanology $62,34-52$.

Gudmundsson, A., Nilsen, K., 2006. Ring faults in composite volcanoes: structures, models and stress fields associated with their formation. In: Troise, C., De Natale, G., Kilburn, C. R. J. (eds.), Mechanisms of Activity and Unrest at Large Calderas. Geological Society of London Special Publications 269, 83-108.

Holohan, E. P., Troll, V. R., van Wyk de Vries, B., Walsh, J. J., Walter, T. R., 2008. Unzipping Long Valley: An explanation for vent migration patterns during elliptical ring fracture eruption. Geology 36, 323-326.

Hoshino, K., Koide, H., Inami, K., Iwamura, S., Mitsui, S., 1972. Mechanical properties of Japanese Tertiary sedimentary rocks under high confining pressures. Geological Survey of Japan 244, 1-200. 
Hubbert, M. K., 1937. Theory of scale models as applied to the study of geologic structures. Bulletin of the Geological Society of America 48, 1459-1520.

Kennedy, B. M., Jellinek, A. M., Stix, J., 2008. Coupled caldera subsidence and stirring inferred from analogue models. Nature Geoscience 1, 385389.

Lipman, P. W., 1984. The roots of ash flow calderas in Western North America: windows into the tops of granitic batholiths. Journal of Geophysical Research 89, 8801-8841.

MacDonald, G.A., 1972. Volcanoes. Prentice-Hall, New Jersey, 510 pp.

Marti, J., Geyer, A; Folch, A., Gottsmann, J., 2008. A review on collapse caldera modeling. In: Gottsmann, J., Marti, J. (eds.), Caldera Volcanism, Volume 10 - Analysis, Modelling and Response. Elsevier, Amsterdam, 336 pp.

Mori, J., McKee, C. O., 1987. Outward-dipping ring-fault structure at Rabaul caldera as shown by earthquake locations. Science 235, 193-195.

Nakada, S., Nagai, M., Yasuda, A., Shimamoto, T., Geshi, N.,Ohno, M., Akimasa, T., Kaneko, T., Fujii, T., 2001. Chronology of the Miyakejima 2000 eruption: characteristics of summit collapsed crater and eruption products. Journal of Geography 110, 168-180 (in Japanese with English abstract).

Nakada, S., Nagai, M., Kaneko, T., Nozawa, A., Suzuki-Kamata, K., 2005. Chronology and products of the 2000 eruption of Miyakejima Volcano, Japan. Bulletin of Volcanology 67, 205218.

Newhall, C. G., Dzurisin, D., 1988. Historical unrest at large calderas of the world, U.S. Geological Survey Bulletin 1855, 1108.

Pitcher, W. S., 1993. The Nature and Origin of Granite. Chapman and Hall, London, 321 p.

Roche, O., Druitt, T. H., Merle, O., 2000. Experimental study of caldera formation. Journal of Geophysical Research 105, 395-416.

Sanford, A. R., 1959. Analytical and experimental study of simple geological structures. Geological Society of America Bulletin 70, 19-52.
Sakai, S., Yamada, T., Ide, S., Mochizuki, M., Shiobara, H., Urabe, T., Hirata, N., Shinohara, M., Kanazawa, T., Nishizawa, A., Fujie, G., Mikada, H., 2001. Magma migration from the point of view of seismic activity in the volcanism of Miyake-jima Island in 2000. Journal of Geography 110, 145-155 (in Japanese with English abstract).

Saunders, S. J., 2001. The shallow plumbing system of Rabaul caldera: a partially intruded ringfault? Bulletin of Volcanology 63, 406-420.

Scandone, R., Acocella, V., 2007. Control of the aspect ratio of the chamber roof on caldera formation during silicic eruptions. Geophysical Research Letters 34, L22307.

Schellart, W., 2000. Shear test results for cohesion and friction coefficients for different granular materials: Scaling implications for their usage in analogue modelling. Tectonophysics 324, 1-16.

Self, S., Goff, F., Gardner, J. N., Wright, J. V., Kite, W. M., 1986. Explosive rhyolitic volcanism in the Jemez Mountains: vent locations, caldera development and relation to regional structure. Journal of Geophysical Research 91B, 1779-1798.

Simkin, T., Howard, K. A., 1970. Caldera collapse in the Galapagos islands, 1968. Science 168, 429437.

Smith, R. L., Bailey, R. A., 1968. Resurgent cauldrons. Geological Society of America Memorial 116, 613-662.

Stix, J., Kennedy, B., Hannington, M., Fiske, R., Mueller, W., Franklin, J., Gibson, H., 2003. Caldera-forming processes and the origin of massive sulfide mineralisation. Geology 41, 375378.

Toda, S., Stein, R. S., Sagiya, T., 2002. Evidence from the AD $2000 \mathrm{Izu}$ islands earthquake swarm that stressing rate governs seismicity. Nature 419, 58-61.

Ueda, H., Fujita, E., Ukawa, M., Yamamoto, E., Irwan, M., Kimata, F., 2005. Magma intrusion and discharge process at the initial stage of the 2000 activity of Miyakejima, central Japan, inferred from tilt and GPS data. Geophysical Journal International 161, 891-906. 
Walter, T. R., Troll, V. R., 2001. Formation of caldera periphery faults: An experimental study. Bulletin of Volcanology 63, 191-203.

Williams, H., 1941. Calderas and their origin. Bulletin of the Department of Geological Sciences, University of California 25, 239-346.

White, D.J., Take, W.A., Bolton, M.D., 2001. Measuring soil deformation in geotechnical models using digital images and PIV analysis. 10th International Conference on Computer Methods and Advances in Geomechanics, Tucson, Arizona.
Yamaoka, K., Kawamura, M., Kimata, F., Fujii, N., Kudo, T., 2005. Dike intrusion associated with the 2000 eruption of Miyakejima Volcano, Japan. Bulletin of Volcanology 67, 231-242.

Zak, J., Paterson, S. R., 2006. Roof and walls of the Red Mountain Creek pluton, eastern Sierra Nevada, California (USA): implications for process zones during pluton emplacement. Journal of Structural Geology 28, 575-587. 


\subsection{Appendix}

\subsubsection{Previous experiments on inward- or outward-dipping ring faults}

The geometry of caldera ring faults has been intensely debated since more than 20 years. However, there exists no consensus whether caldera ring faults are inward- or outwarddipping, upward- or downward-propagating. The table provides a summary about experimental works that tried to solve these questions.

Author

Komuro, 1987

Marti et al., 1994

Gudmundsson et al., 1997

Burov \& Guillou-Frottier, 1999

Acocella et al., 2000

Roche et al., 2000

Walter \& Troll, 2001

Kusumoto \& Takemura, 2003

Folch \& Marti, 2004

Gray \& Monaghan, 2004

Kennedy et al., 2004

Pinel \& Jaupart, 2005

Geyer et al., 2006

Acocella 2007, 2008

$\begin{array}{ll}\text { Method } & \text { Reverse fault propagation } \\ \text { sand box } & \text { upward } \\ \text { sand box } & \text { upward } \\ \text { numerical } & \text { - } \\ \text { numerical } & \text { - } \\ \text { sand box } & \text { upward } \\ \text { sand box } & \text { upward } \\ \text { sand box } & \text { upward } \\ \text { numerical } & \text { upward } \\ \text { numerical } & \text { - } \\ \text { numerical } & \text { - } \\ \text { sand box } & \text { upward } \\ \text { numerical } & - \\ \text { sand box } & \text { upward } \\ \text { review } & \text { upward }\end{array}$

Normal fault propagation
upward
upward
downward
upward
upward
upward
upward
upward
downward
downward
upward
downward
downward
upward

Table 4.1. Sandbox and numerical models suggest both inward and outward dipping caldera ringfaults.

\subsubsection{Experimental scaling}

Analogue experiments were geometrically and dynamically scaled. A scaling ratio of $2.5 \times 10^{-5}$ was applied in all experiments. Gravity and density were constant, so that the stress ratio is $1.25 \times 10^{-5}$. The scaling procedure described in earlier studies (see Length ratio $\quad L^{*}=L_{\text {exp }} / L_{\text {nature }}=2.5 \times 10^{-5}$ Gravity ratio $g^{*}=1$ Density ratio $\rho^{*} \approx 0.5$ Stress ratio $\quad \sigma^{*}=\rho^{*} g^{*} L^{*}=1.25 \times 10^{-5}$ Section 4.2.1) was applied: 
Material properties were tested in a ring shear apparatus at the Geodynamics Lab of GFZ Potsdam. The results for a starchsand mixture of 1:5 yield a cohesion of about $70 \mathrm{~Pa}$ and an angle of internal friction of $28^{\circ}$ (Table 4.2 and 4.3; Fig. 4.8).

\begin{tabular}{|l|l|}
\hline Material & $\begin{array}{l}1: 5 \text { starch-sand } \\
\text { mixture }\end{array}$ \\
\hline Cohesion & $70.36 \mathrm{~Pa}$ \\
\hline $\begin{array}{l}\text { Angle of internal } \\
\text { friction }\end{array}$ & $27.6^{\circ}$ \\
\hline
\end{tabular}

Table 4.2 Result of ring-shear test.

\begin{tabular}{|c|c|c|}
\hline Loading cycle & critical force [kg] & tau critical [Pa] \\
\hline 1 & 0,487 & 340,41 \\
\hline 2 & 0,867 & 606,02 \\
\hline 7 & 0,511 & 357,18 \\
\hline 8 & 0,843 & 589,24 \\
\hline 13 & 0,426 & 297,77 \\
\hline 14 & 0,836 & 584,35 \\
\hline
\end{tabular}

Table 4.3. Result of ring-shear test.

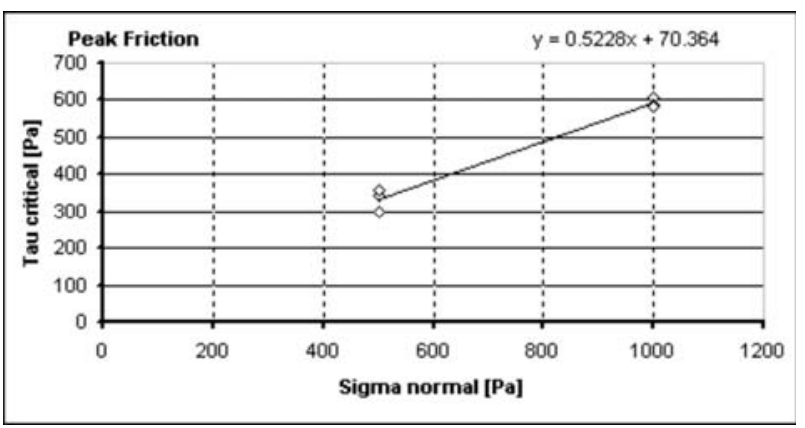

Figure 4.8. Results of ring-shear test.

\subsubsection{Digital Image Correlation (DIC) method details}

The DIC method correlates two successive images recorded at $t_{1}$ and $t_{2}$. During postprocessing the recorded images to be compared analysed successively in interrogation windows, small quadratic or circular areas, some pixels in diameter, in which the pixel pattern of both images is compared by fast Fourier transformation. From the results, a displacement vector is calculated for the area of the interrogation window. Then the interrogation window is moved. An overlap between successive interrogation windows enhances the spatial resolution of the vector calculation. A further enhancement of the spatial resolution can be achieved by adaptive multi-pass correlation (Fincham and Spedding, 1997; Scarano and Riethmuller, 2000; Wienecke, 2001) and by decreasing the size of the interrogation windows. In adaptive multi-pass correlation, the results of each pass are used to adapt the shift of the interrogation window.

The spatial resolution of the calculated results, thus, depends on the optical resolution of the camera used and the parameters of the postprocessing, including the size of the interrogation windows and the parameters of the multi-pass correlation.

For the complete displacement vector field, the displacement vectors of all interrogation windows are combined. From the calculated vector field, information about particle paths in $\mathrm{x}$ - or $\mathrm{x}$-direction, particle velocity, or strain tensor components can be derived. From the components of the strain tensor, rotational shear strain around the z-axis (perpendicular to $\mathrm{x}$ and $\mathrm{y}$ ), Poisson's ratio, and the shear strength can be deduced. 
4.6.4 The influence of the chamber aspect ratios

In general, the sequence of ring fault formation and propagation observed in our experiments was observed in detail (Fig. $4.9,4.10)$ and independent of the roof aspect ratio AR (Fig. 4.11).

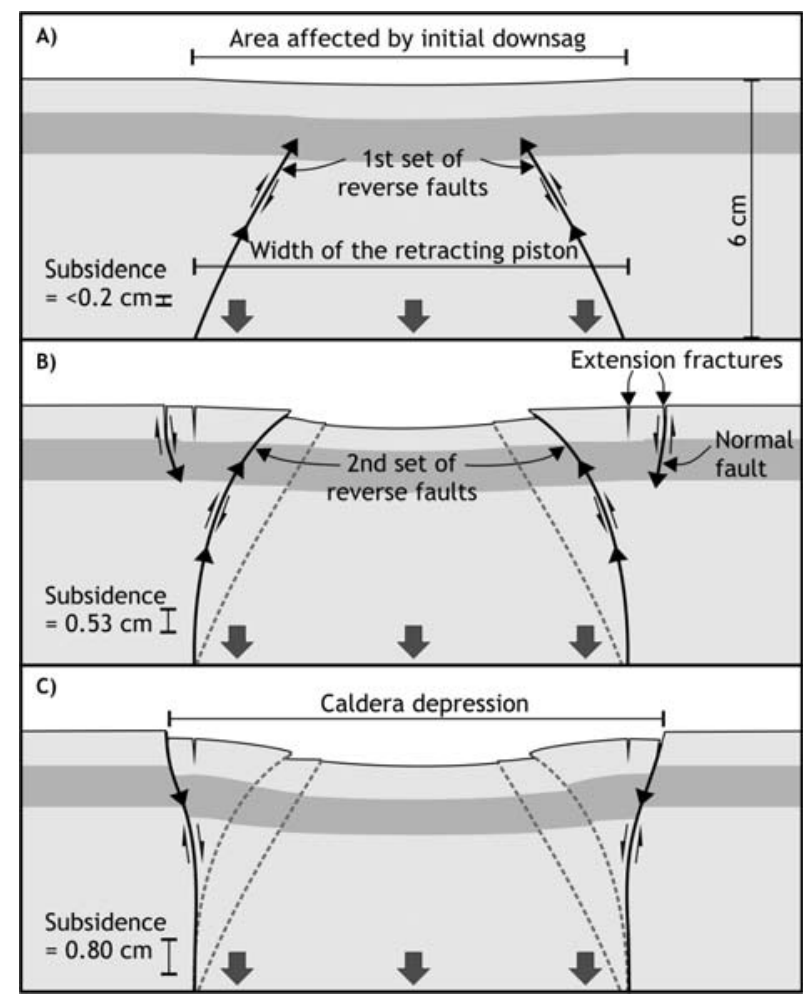

Figure 4.9. Sequence of propagating ring faults for shallow chamber. Interpretation of the results of experiment 2D_15-110 and Movie 4.1. The results are representative for all experiments with roof aspect ratios $<1$. Solid, black lines represent active faults, whereas dashed, grey lines represent inactive faults. Arrow heads represent propagation direction.

Hence, the final configuration for all experiments was very similar: a central subsiding piston bounded by ring faults that are steeply inward-dipping near the surface and subvertical to very steeply outward-dipping at depth. The amount of subsidence controls when this final (or any other) stage in the sequence is reached. However, there is no linear trend between subsidence and the occurrence of a certain stage. We therefore propose that ring fault evolution is a continuum rather than a stepwise process as shown below.

The interpretation of the results of experiment 2D_15-110 is provided in the Figure 4.9 and Movie 4.1. The results are representative for all experiments with roof aspect ratios $<1$. It is shown that a first set of reverse faults propagates to the surface (Fig. 4.9A), followed by a second set of reverse faults (Fig. 4.9B). Normal faults start to propagate downwards from extension fractures at the surface. The first set of reverse faults is inactive. The piston is bounded by inward-dipping normal faults close to the surface and steeply outward-dipping to subvertical faults at depth (Fig. 4.9C). Both the first and the second set of reverse faults are inactive.

Experiments with a roof aspect ratio of 1.54 are shown in the Figure 4.10 and Movie 4.2, and show that individual fault segments can be reactivated at higher subsidence rates.

Correlation between the achievement of individual ring-fault configurations and the subsidence for ten experiments with different roof aspect ratios further supports the hypothesis that a general sequence of events is given for different chamber depths or widths. The sequence of events is similar for all aspect ratios; the required subsidence, however, depends on the aspect ratio. 

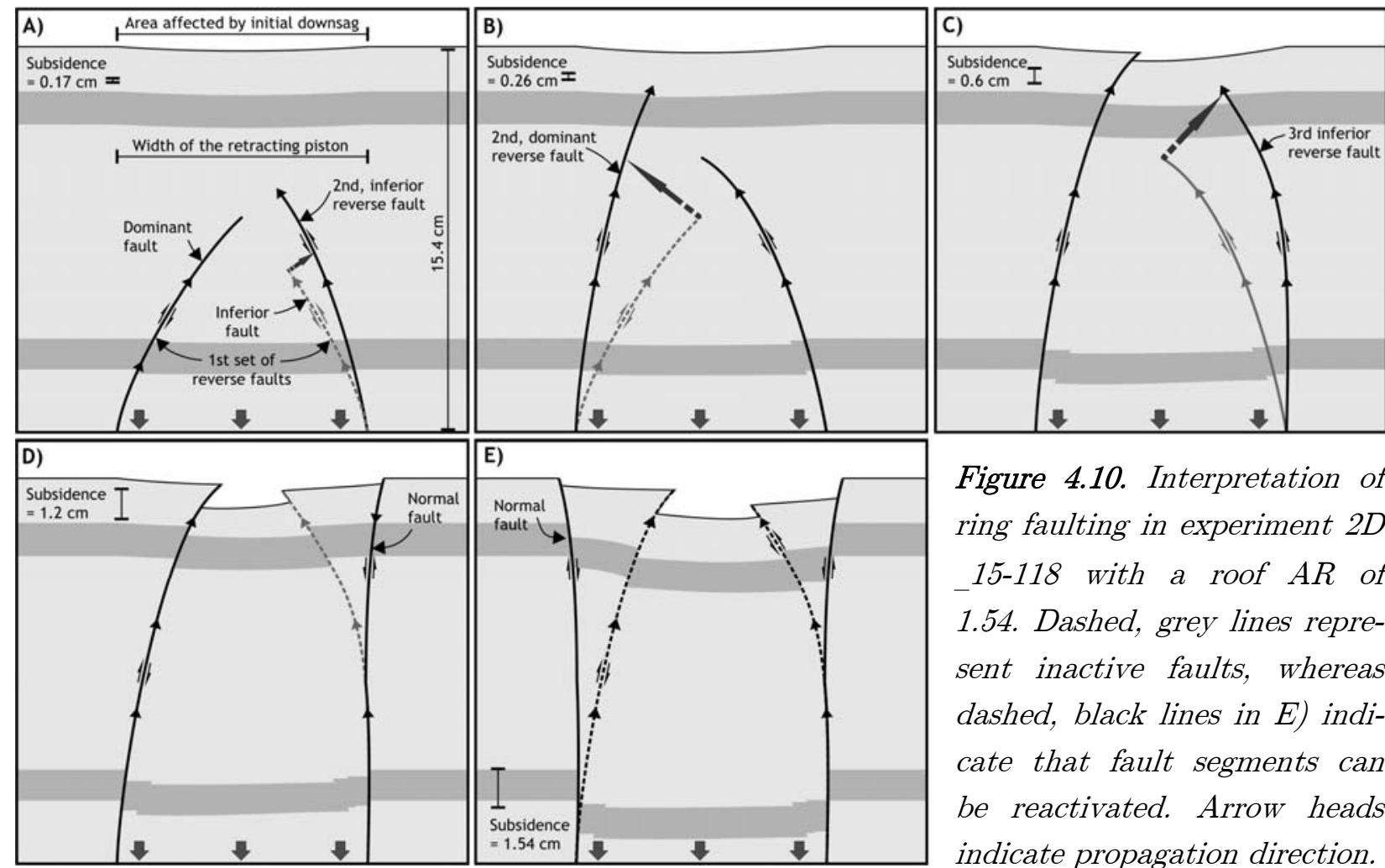

Figure 4.10. Interpretation of ring faulting in experiment $2 D$ _15-118 with a roof $A R$ of 1.54. Dashed, grey lines represent inactive faults, whereas dashed, black lines in E) indicate that fault segments can be reactivated. Arrow heads indicate propagation direction.

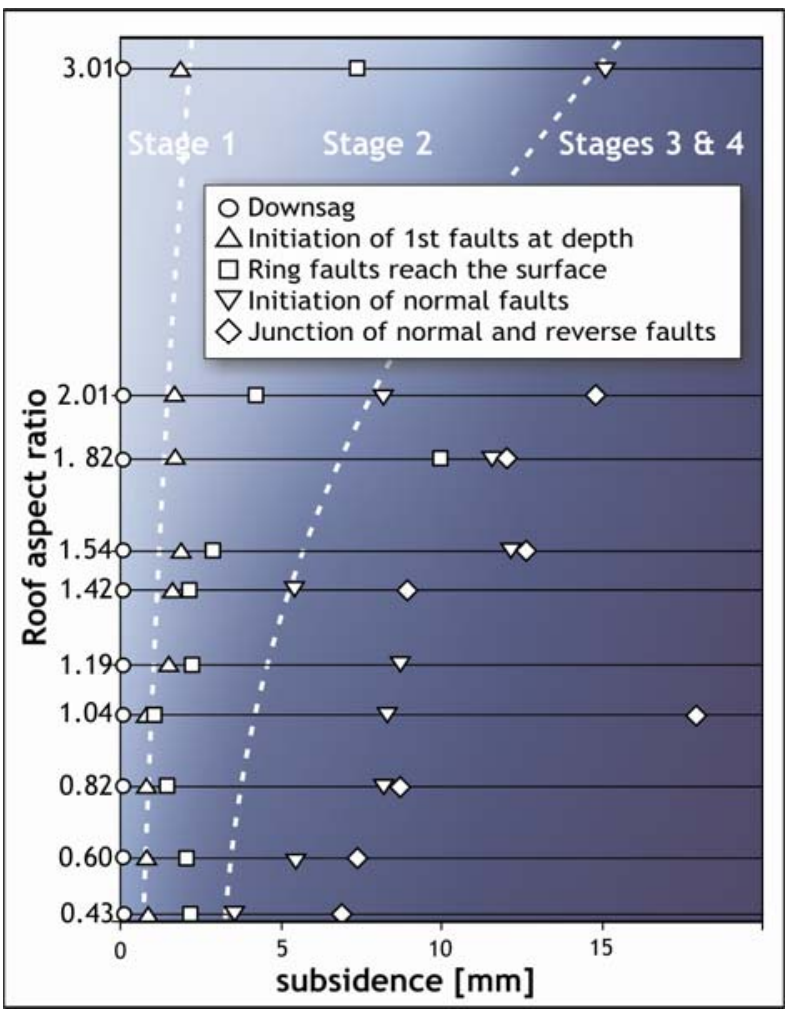

Figure 4.11. Synthesis of all experiments. Correlation between the achievement of individual ring-fault configurations (see legend) and the subsidence for ten experiments with different roof aspect ratios. Stage 1: Downsag; Stage 2: reverse ring-fault; Stages 3 \& 4: peripheral normal faulting (Acocella, 2007).

4.6.5 Electronic appendix - movies

Movie 4.1. Movie of the results of experiment No. 2D_15-110 with a roof aspect ratio of 0.6 . The actually recorded images of the experiment are shown in the background, while the colours in the foreground display the maximum shear strain (see scale on the right hand side) calculated. The duration of the experiment is $120 \mathrm{~s}$, during which a subsidence of 1.8 
$\mathrm{cm}$ was achieved. The spatial resolution of the data processing is around $0.2 \mathrm{~mm}$. Movie is in AVI format, runs in IrfanView and many other free players.

Movie 4.2. Movie of the results of experiment No. 2D_15-118 with a roof aspect ratio of 1.54. Colours display rotational strain around the $\mathrm{z}$-axis (perpendicular to screen; see scale on the right hand side) calculated. Red colour represents counter-clockwise rotation of the particles, whereas blue colour represents clockwise rotation of the particles. The duration of the experiment is $120 \mathrm{~s}$, during which a subsidence of $1.8 \mathrm{~cm}$ was achieved. The spatial resolution of the data processing is around $0.2 \mathrm{~mm}$. Movie is in AVI format, runs in IrfanView and many other free players.

\subsubsection{References of Appendix}

Acocella, V., 2007. Understanding caldera structure and development: An overview of analogue models compared to natural calderas. EarthScience Reviews 85, 125-160.

Acocella, V., 2008. Structural development of calderas: a synthesis from analogue experiments. In: Gottsmann, J., Marti, J. (eds.), Caldera Volcanism. Analysis, Modelling and Response. Elsevier, Amsterdam, 336 p.

Acocella, V., Cifelli, F., Funiciello, R., 2000. Analogue models of collapse calderas and resurgent domes. Journal of Volcanology and Geothermal Research 104, 81-96.

Burov, E. B., Guillou-Frottier, L., 1999. Thermomechanical behaviour of large ash flow calderas. Journal of Geophysical Research 104, 23081-23109.

Fincham, A. M., Spedding, G. R., 1997. Low cost high resolution DPIV for measurement of turbulent fluids. Experiments in Fluids 23, 449462.

Folch, A., Marti, J., 2004. Geometrical and mechanical constraints on the formation of ringfault calderas. Earth and Planetary Science Letters 221, 215-225.

Geyer, A., Folch, A., Martí, J., 2006. Relationship between caldera collapse and magma chamber withdrawal: An experimental approach. Journal of Volcanology and Geothermal Research 157, 375-386.

Gray, J. P., Monaghan, J. J., 2004. Numerical modelling of stress fields and fracture around magma chambers. Journal of Volcanology and Geothermal Research 135, 259-283.

Gudmundsson, A., Martí, J., Turon, E., 1997. Stress field generating ring faults in volcanoes. Geophysical Research Letters 24, 1559-1562.

Kennedy, B. M., Styx, J., Vallance, J. W., Lavallee, Y., Longpre, M. A., 2004. Controls on caldera structure: results from analogue sandbox modeling. Geological Society of America Bulletin 106, 515-524.

Komuro, H., 1987. Experiments on cauldron formation: a polygonal cauldron and ring fractures. Journal of Volcanology and Geothermal Research 31, 139-149.

Kusumoto, S., Takemura, K., 2003. Numerical simulation of caldera formation due to collapse of a magma chamber. Geophysical Research Letters 30, 2278.

Marti, J., Ablay, G. J., Redshaw, L. T., Sparks, R. S. J., 1994. Experimental studies of collapse calderas. Journal of the Geological Society of London 151, 919-929.

Pinel, V., Jaupart, C., 2005. Caldera formation by magma withdrawal from a reservoir beneath a volcanic edifice. Earth and Planetary Science Letters 230, 273-287.

Roche, O., Druitt, T. H., Merle, O., 2000. Experimental study of caldera formation. Journal of Geophysical Research 105, 395-416.

Scarano, F., Rietmuller, M. L., 2000. Advances in iterative multigrid PIV image processing. Experiments in Fluids (Supplements) 29, 51-60. 
Walter, T. R., Troll, V. R., 2001. Formation of caldera periphery faults: An experimental study. Bulletin of Volcanology 63, 191-203.
Wienecke, B., 2001. PIV adaptive multi-pass correlation with deformed interrogation windows. PIV Challenge 2001 1-6. 
This chapter consists of two manuscripts.

Section 5.1 has been submitted to Tectonophysics as:

Burchardt, S., Tanner, D. C., Krumbholz, M., submitted. Mode of emplacement of the Slaufrudalur Pluton, Southeast Iceland inferred from three-dimensional GPS mapping and model building. Submitted to Tectonophysics.

Section 5.2 has been submitted to Journal of Structural Geology as:

Burchardt, S., Tanner, D. C., Krumbholz, M., submitted. Emplacement of the Slaufrudalur Pluton, Southeast Iceland. Submitted to Journal of Structural Geology.

5. Emplacement of the Slaufrudalur Pluton, Southeast Iceland

5.1 Mode of emplacement of the Slaufrudalur Pluton, Southeast Iceland inferred from threedimensional GPS mapping and model building

\begin{abstract}
The Slaufrudalur Pluton is a granitic pluton in the Tertiary lava pile of Southeast Iceland. Excellent exposures of its roof and walls made it possible to map the shape of the pluton with high-resolution GPS. Based on the GPS mapping and field observations, we reconstructed the three-dimensional shape of the Slaufrudalur Pluton. The reconstructed pluton shape is characterised by steep walls and a flat roof at map-scale. This shape and the internal compositional layering indicate that the pluton was probably emplaced by cauldron subsidence along subvertical faults that are parallel with the strike of the regional fissure swarms. At the roof contact, the pluton exploited the original layering of the flood basalts. At outcrop-scale, however, the roof was modified by magmatic stoping, which resulted in a step-like pattern. Hence, the reconstruction of the three-dimensional shape of the Slaufrudalur Pluton, combined with structural field studies, provided valuable information about the mechanism of its emplacement on pluton-scale.
\end{abstract}

\title{
5.1.1 Introduction
}

Observation and reconstruction of the present-day geometry of plutons offer a way to infer pluton-emplacement mechanisms. Most are, however, limited to two-dimensional exposures of walls, roof, and interior of the intrusive bodies. Conse- quently little is directly known about the three-dimensional structure of plutons (John, 1988; Vigneresse, 1990; Pitcher, 1993). Particularly the roof structures of a pluton reflect the dominant near-field material transport and therefore yield most 
information about the mechanism of emplacement (Paterson and Fowler, 1993). The Slaufrudalur Pluton is a $15 \mathrm{~km}^{2}$ large (in map view) granitic intrusion, located in the Tertiary basaltic lava pile of Southeast Iceland (Fig. 5.1). It is one of the rare examples where the roof and walls of a pluton are so excellently exposed in several sections that the three-dimensional shape of the upper $\sim 900 \mathrm{~m}$ of the pluton can be reconstructed. The main aim of this paper is to demonstrate how the reconstruction of a pluton's three-dimensional shape can help to infer the mode of emplacement. We

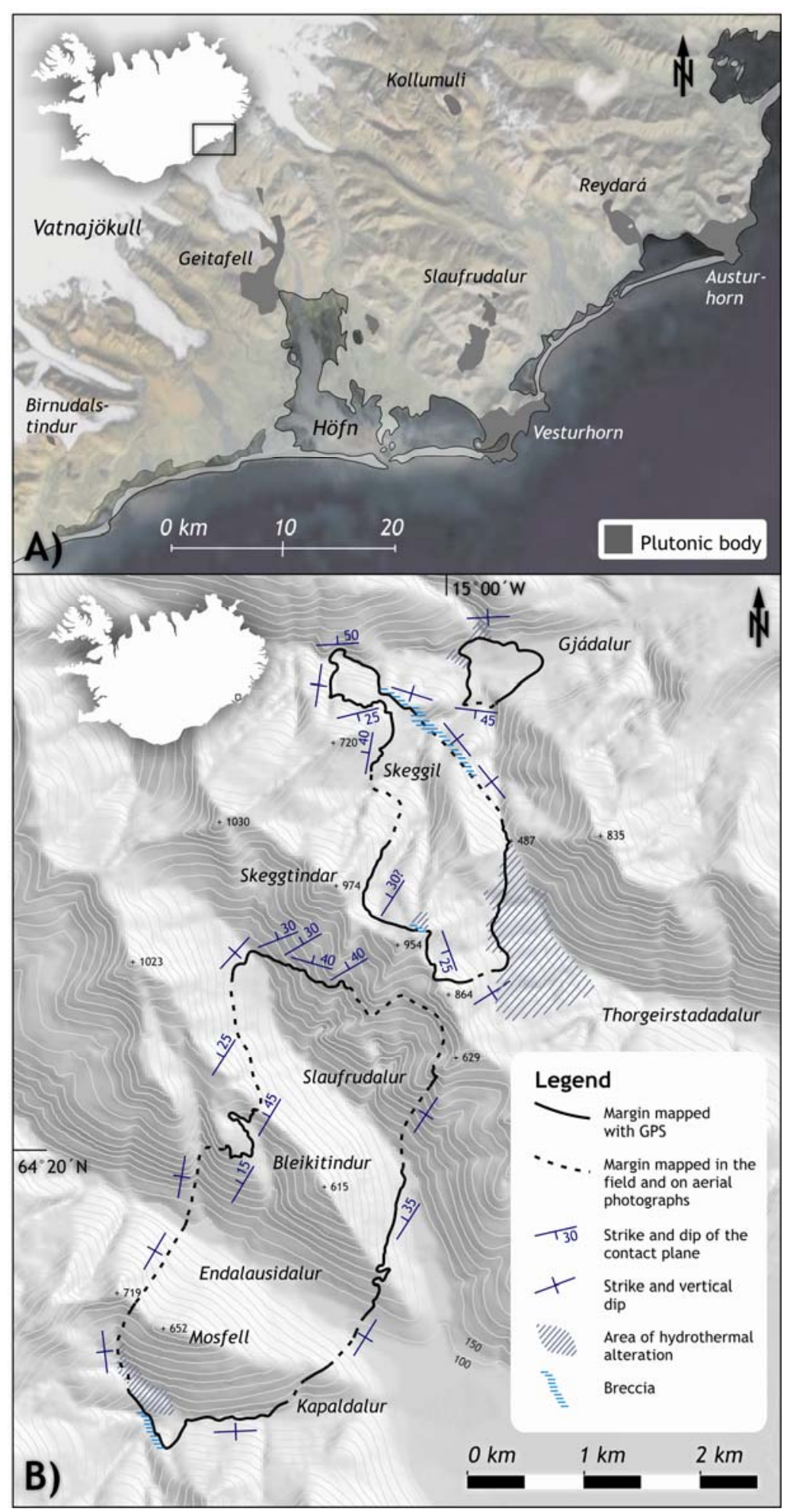

present a three-dimensional digital model of the Slaufrudalur Pluton, as constructed from detailed GPS measurements and structural field studies. Based on this three-dimensional model and field observations, we infer that the main volume of the Slaufrudalur Pluton was created by cauldron subsidence or floor sinking, whereas the roof contact was modified by subsequent magmatic stoping. Hence, two different material transfer processes that acted on different scales controlled the emplacement of the Slaufrudalur Pluton.

Figure 5.1. A) Location map of major intrusions in Southeast Iceland. Background satellite image provided by Google Earth. B) Map of the Slaufrudalur Pluton with contact features and orientations. The Digital Elevation Model (DEM) of Iceland, provided by the National Land Survey of Iceland, served as map basis. Cell size is $25 \mathrm{~m}$. 


\subsubsection{Geological setting}

Apart from some earlier notes on its existence (see Cargill et al., 1928 for references), there have been only three detailed geological studies of the Slaufrudalur Pluton: Cargill et al. (1928), Beswick (1965), and Carmody (1991). Cargill et al. (1928) presented a comprehensive description of the features of the pluton that can be observed in the field, as well as the first map and some cross sections, whereas Beswick (1965) and Carmody (1991) focused mainly on petrography and geochemistry of the rocks. The Slaufrudalur Pluton consists of granophyric and granitic rocks of granitic to granodioritic composition (Cargill et al., 1928; Beswick, 1965; Carmody, 1991). KAr whole-rock ages range from $6.5 \pm 0.4 \mathrm{Ma}$ to $10.0 \pm 1.0 \mathrm{Ma}$ (Gale et al., 1966; Burchardt, 2006).

The Slaufrudalur Pluton was emplaced at a depth of around $1 \mathrm{~km}$ below the Tertiary surface of the Icelandic rift zone (cf. Walker, 1974) into flat-lying flood basalts that were later tilted by up to $10^{\circ}$, together with the pluton, in a large N-S striking flexure zone (see Section 2.2.2; Walker, 1974). The map dimensions of the pluton are $\sim 2 \times 7.5 \mathrm{~km}^{2}$ (Fig. 5.1). Its long axis strikes $018^{\circ}$ and coincides with the strike of a regional basaltic dyke and fissure swarm in the area (Cargill et al., 1928; Walker, 1974; Torfason, 1979). As a result of deep glacial erosion, the Slaufrudalur Pluton is exposed in five natural cross-sections along the valleys of Gjádalur, Thorgeirstadadalur, Slaufrudalur,
Endalausidalur, and Kapaldalur (Fig. 5.1). These valleys reveal sections from the roof down through around $900 \mathrm{~m}$ thickness of the pluton, below the ridges of Skeggtindar, Bleikitindur, and Mosfell. In addition, large parts of the roof and wall contacts are excellently exposed in outcrops. Unfortunately the floor of the pluton is not exposed, so that its total thickness is unknown.

From their field observations of the steep walls and the almost flat roof, and the absence of large volumes of country-rock xenoliths, Cargill et al. (1928) suggested that the pluton formed under tension by cauldron subsidence rather than piecemeal stoping. Beswick (1965) described the shape of the pluton as an elongated dome and inferred that the walls of the intrusion represent an elliptical ring-fracture and the roof a truncating cross-fracture that connected the walls. A compositional layering that had already been recognised by Cargill et al. (1928), and analysed in detail by Beswick (1965) and Carmody (1991), was used as evidence for incremental subsidence of the country-rock that was replaced by successive magma injections as sills (Cargill et al., 1928; Beswick, 1965), a process described as cauldron (Clough et al., 1909) or floor subsidence (e.g. Cruden, 1998; Cruden and McCaffrey, 2001).

The internal, subhorizontal layering is characterised by compositional and textural changes; the transition between layers is abrupt with chilling or transitional with intermingling structures but generally obscure on outcrop-scale (Beswick, 1965). 
Carmody (1991), who analysed the origin and structure of the layering, concluded that it is not the result of density contrast between the compositionally different magmas, and that the pluton filled from the top down in at least 23 different injections with an average volume of 0.34 $\mathrm{km}^{3}$. She also found accumulations of mmto cm-scale basaltic xenoliths at the bottom of some of the layers, but proved from their composition that they originated by stoping in the source magma-chamber that fed the Slaufrudalur Pluton. Since on closer inspection, the contacts between layers are obscure, both Beswick (1965) and Carmody (1991) tried to map or at least correlate individual layers of adjacent vertical sections, without success. Carmody (1991) concluded that individual units have complex geometries and are rather tongue- than sill-like.

\subsubsection{Structural field studies and three- dimensional mapping}

The shape of the Slaufrudalur Pluton was mapped during a field campaign in August and September 2007. Since the margin between the pluton and the basaltic host rock is almost entirely exposed, we were able to record it with a GPS device. The device used was a Trimble Pathfinder Pro HX. It consists of a handheld PC, a GPS receiver, and an external antenna. The maximum achievable accuracy during this mapping was 4 decimetres in horizontal direction and 7 decimetres in vertical direction, after postprocessing. For the latter, correction data provided by the
GPS reference station in Höfn, Iceland, were used.

The aim of the GPS mapping was to record the exact location and, where possible, the strike and dip of the contact plane between basaltic host rock and the pluton. Accordingly, the margin of the Slaufrudalur Pluton was mapped either (1) as a line following the contact or (2) as a set of individual points, where the attitude of the contact plane could be measured at the same time. Our GPS mapping covered the main part of the exposed margin that comprises parts of the walls, as well as several sections through the roof of the pluton. In Figure 5.1, the part of the contact that was mapped with the GPS is illustrated by solid lines. The inaccessible part of the margin was mapped from field observations and aerial photographs (illustrated by dashed lines in Fig. 5.1). Our results coincide well with the map published by Cargill et al. (1928), but are of course much more detailed.

While mapping, we were also able to analyse the features and orientation of the contact between pluton and host rock. In general, there are some differences between roof and wall contacts. The pluton walls dissect the flat-lying basalts at approximate right angles. In contrast to Cargill et al. (1928), we did not observe any host-rock deformation such as doming, up- or down-bending in the vicinity of the walls. Unfortunately, good outcrops of the wall contacts are scarce; they are mostly obscured by scree. Thus, we could not observe shear indicators on the pluton walls. At two locations, we found evidence 
of faults forming the contact. To the northeast, there is a broad, brittle fault zone ( 10 to 30 metres thick), which represents the margin of the pluton in the two Skeggil canyons and the ridges in between (Fig. 5.1). The fault zone strikes $134^{\circ}$, is vertical, and characterised by a basaltic fault breccia (up to 10 metres thick). However, this breccia does not show any indication of the sense of shear.
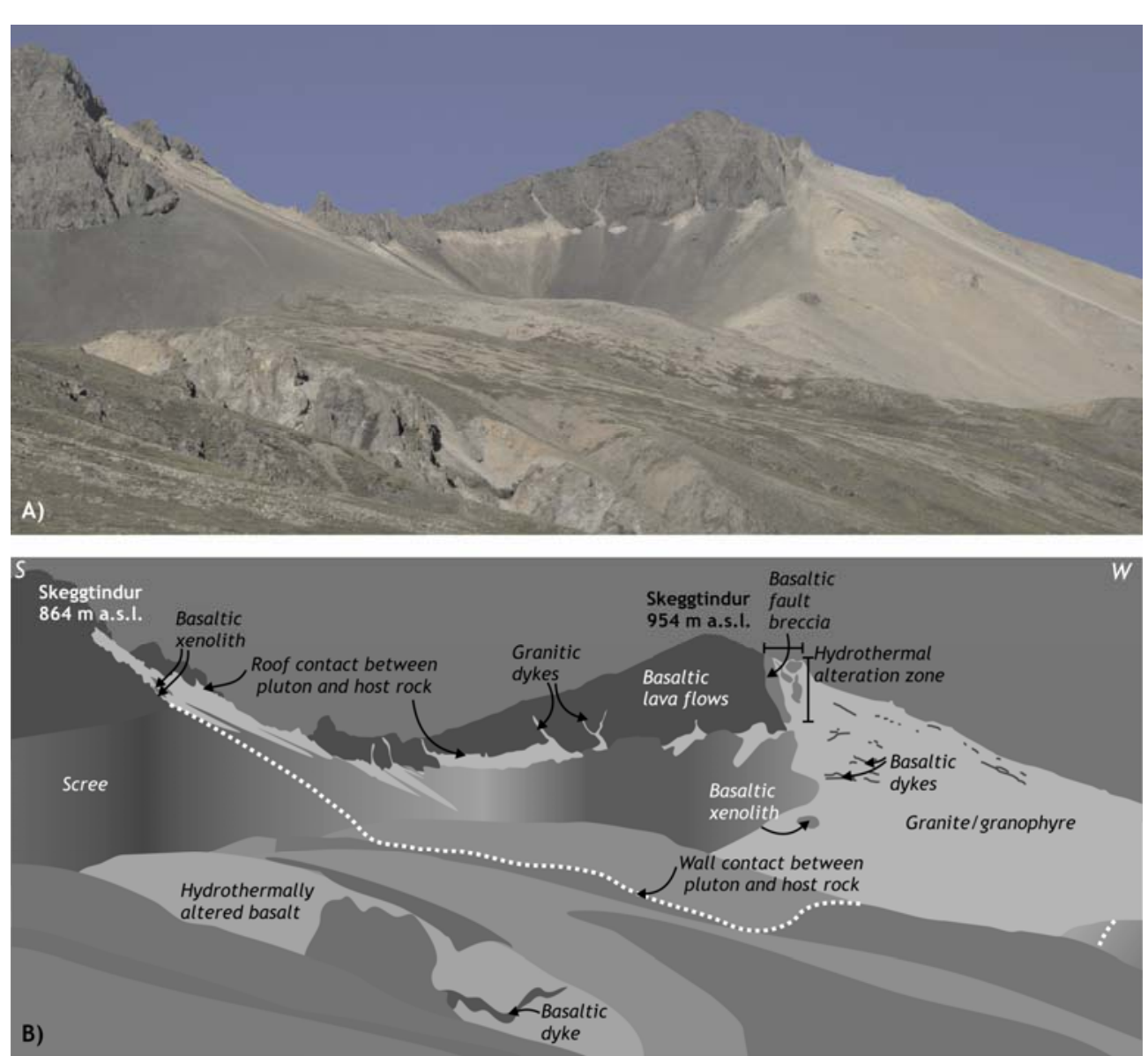

Figure 5.2. A) Panoramic view of the Slaufrudalur Pluton on the upper Thorgeirstadadalur. B) Schematic sketch with explanation of the photograph in A). The roof contact of the Slaufrudalur Pluton is characterised by steps and granitic dykes that intruded the host rock. $N$ of the peak of Skeggtindur $954 \mathrm{~m}$ a.s.l., there is a vertical fault/alteration zone between host rock and pluton. At this point, the roof of the pluton loses more than 50 metres of height. Inside the pluton, several basaltic dykes and a few basaltic xenoliths from the roof rocks occur. The vertical wall contact in the foreground separates the strongly hydro-thermally-altered basaltic host-rock from the less-altered granite of the pluton.
In contrast, the pluton roof contacts are knife sharp. The overlying basalt has a glassy, altered appearance within centimetres to metres from the contact, while the granite is macroscopically homogeneous. The contact itself is sharp and straight at meso-scale (decimetres to metres). However, many steps and cuspate indentations occur along the contact and range in size from decimetres to tens of metres (Figs. $5.2 \& 5.3$ ).

The most complete cross section through the pluton and the over- 
lying rocks is located below the Skeggtindar ridge, on the northern slope of the Slaufrudalur valley (Fig. 5.3). The contact below Skeggtindur (629 m a.s.l.) dips steeply but changes rapidly to a shallow dip towards the summit. It therefore represents the transition from the eastern wall of the pluton to the roof.
Section 2.2.2; Walker, 1974). The western margin of the pluton, exposed in the river valley in Slaufrudalur, dips steeply.

Thus, based on field observations, the cross-sectional shape of the pluton appears to be is a slightly tilted dome with steep walls and a relatively flat roof. The transition is abrupt within metres.

The much smaller, separate outcrop of granite at Gjádalur has a circular shape in map view, with relatively steeplydipping margins. The exposure trace surrounds the point where the four canyons meet. In the northernmost canyon, the margin is sharp and steeplydipping. Upstream
Figure 5.3. A) Panoramic view of the exposure of the Slaufrudalur Pluton on the southern slopes of the Skeggtindar ridge above the valley of Slaufrudalur. B) Schematic sketch with explanation of the photograph in A). The roof contact of the Slaufrudalur Pluton exhibits numerous steps and cuspate indentations, as well as granitic dikes that intruded the roof rock. There are also roof pendants. However, in this section, basaltic xenoliths are scarce.

The roof itself is relatively flat, with numerous steps and cuspate indentations. It dips with approximately $10^{\circ}$ to the west, which is consistent with the tilt inside the East-Icelandic flexure zone in this area (see at Gjádalur, the contact is not sharp. Instead, an approximately 10 metre thick alteration zone occurs in the basalt. Where the two Skeggil canyons meet, the contact is exposed and dips $\sim 45^{\circ} \mathrm{S}$. Only around $400 \mathrm{~m}$ to the southwest, is the main pluton terminated by the brittle fault zone described above. Thus, the circular outcrop of granite in Gjádalur is not structurally linked with the larger granite pluton to the south. However, the macroscopic appearance of the granite and its location suggest a genetic link between the intrusions (Fig. 5.1). 
5.1.4 Reconstruction of the threedimensional shape of the pluton

Based on the results of our structural field studies and the GPS mapping, we first created a new map of the Slaufrudalur Pluton, including the strike and dip of the contact plane and our observation of the contact features (Fig. 5.1). As a map base, we used the digital elevation model (DEM) of Iceland provided by the National Land Survey of Iceland, with a cell size of 25 metres. Then DEM and the GPS points and lines were imported into GoCAD 2.0.8. In GoCAD, the measured attitudes of the contact plane were projected up- and down-dip, and if necessary, along strike, to produce surfaces. Where it was not possible to map with the GPS device, we used the $3 \mathrm{D}$ form of the exposure trace and our observations to construct the contact surface. We reconstructed the contact to a maximum depth not deeper than sea-level, because this is the lowest exposure.

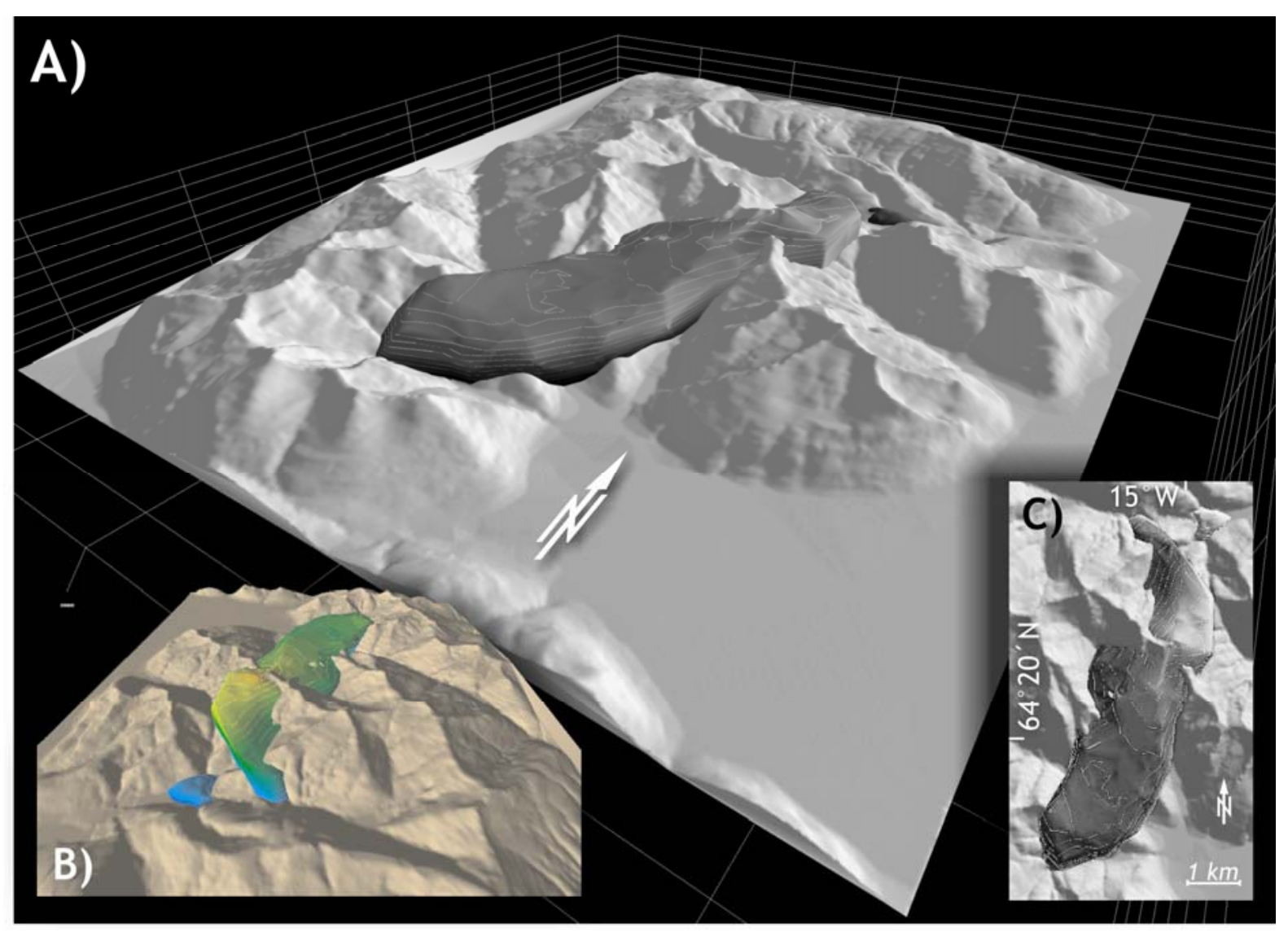

Figure 5.4. Perspective view of the reconstructed three-dimensional shape of the Slaufrudalur Pluton.

A) Model above the topographic surface (DEM provided by the National Land Survey of Iceland). Gray scaling of the pluton represents depth. Isolines on the pluton surface are elevation contours at $50 \mathrm{~m}$ spacing. Scale varies with perspective. B) Model as seen from the north. The straight, vertical termination of the Slaufrudalur Pluton in the northeast is represented by a brittle fault zone. The small granite outcrop in Gjádalur seen in the foreground was modelled as a separate body since there is no field evidence for a structural connection. Scale varies with perspective. C) Map view of the model. Note consistency with real map view in Figure 5.1. 
Finally, a new surface was created using the software package 3DMove, to envelop all the GoCAD surfaces. The result is shown in Figure 5.4 and the Movie in the Electronic Supplementary material.

The three-dimensional shape of the Slaufrudalur Pluton resembles a relatively smooth, elongated, rhomboid body with a volume of 8 to $10 \mathrm{~km}^{3}$ above sea level, 4 $\mathrm{km}^{3}$ of which have been eroded. Twodimensional sections of the pluton model and the stereographic projection of the contact surface orientations (Figs. 5.5-5.7) document that the pluton roof is flat, whereas the walls are steep.

Figure 5.5. Compilation of cross sections (perpendicular to strike) through the three-dimensional model in Figure 5.4. The distance between individual cross sections is 300 $m$. The projection of the slices goes down approximately to sea level. The slices show that the roof is more or less flat. Especially in the central sections that have the smallest error,

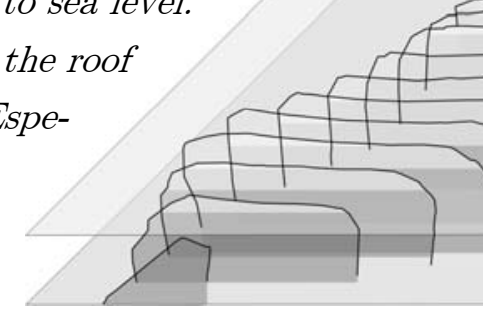
small irregularities (step-like pattern) at a scale of less than $100 \mathrm{~m}$ are visible. The plunge of the roof to the $W$ is a result of the regional tilting of approximately $10^{\circ} \mathrm{W}$ (Walker, 1974).

The transition between walls and roof, i.e. the upper edge of the pluton, is sharp. The walls are mostly vertical. The northeastern margin of the pluton is represented by a straight, vertical fault that cuts the roof. The roof itself is relatively flat, except for a structural high in the area around Skeggtindar $864 \mathrm{~m}$ a.s.l. and $954 \mathrm{~m}$ a.s.l. (cf. Fig. 5.6 cross section C-C'), and a low in the north-westernmost part. The steps and cuspate indentations observed in the field could only be considered for those parts that were mapped with GPS. In general, they are hardly noticeable at pluton-scale (cf. e.g. Fig. 5.5). We therefore postulate that the roof consists of a steplike pattern at a scale from metres to tens of metres (Fig. 5.3), although the overall roof geometry as displayed in the threedimensional model (Fig. 5.4) is rather flat with few irregularities at map-scale.

The granite outcrop in Gjádalur was constructed as an independent body based on field evidence (see above). The Gjádalur

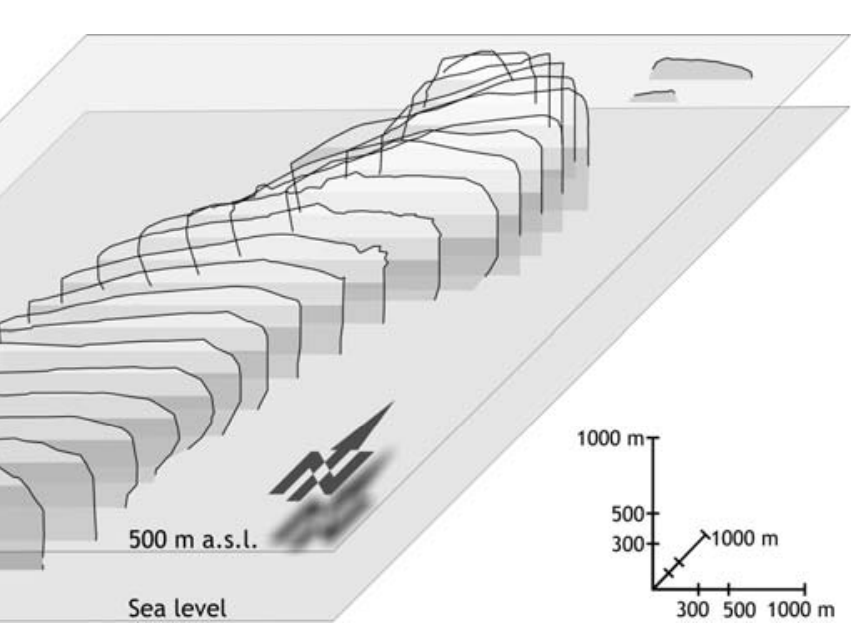

intrusion has the shape of a small dome with steep walls except to the south, where the wall dips $\sim 45^{\circ} \mathrm{S}$. This also provided constraints on its roof height and geometry. Thus, the roof is relatively flat, S-dipping, and lies considerably deeper than the roof of the main intrusive body. The fault that cuts off the main pluton to the northeast, the proximity of the two intrusions, and the macroscopic resemblance of the rocks suggest a genetic connection between the plutons. However, 
the shape of the Gjádalur intrusion does not indicate the type of connection.

The accuracy of the constructed threedimensional bodies ranges from metres, for those parts of the margin that were mapped with GPS, to approximately $50 \mathrm{~m}$ for those parts that were mapped from field observation and aerial photographs. the height of the highest granite outcrop (e.g. the peaks of Mosfell and Bleikitindur) and the dip of the remaining roof outcrop as constraints. We therefore estimate the error of these parts to be 100 metres. The error for the parts beneath the surface between the Skeggtindar $1030 \mathrm{~m}$ a.s.l., 954 $\mathrm{m}$ a.s.l., and $720 \mathrm{~m}$ a.s.l. is probably
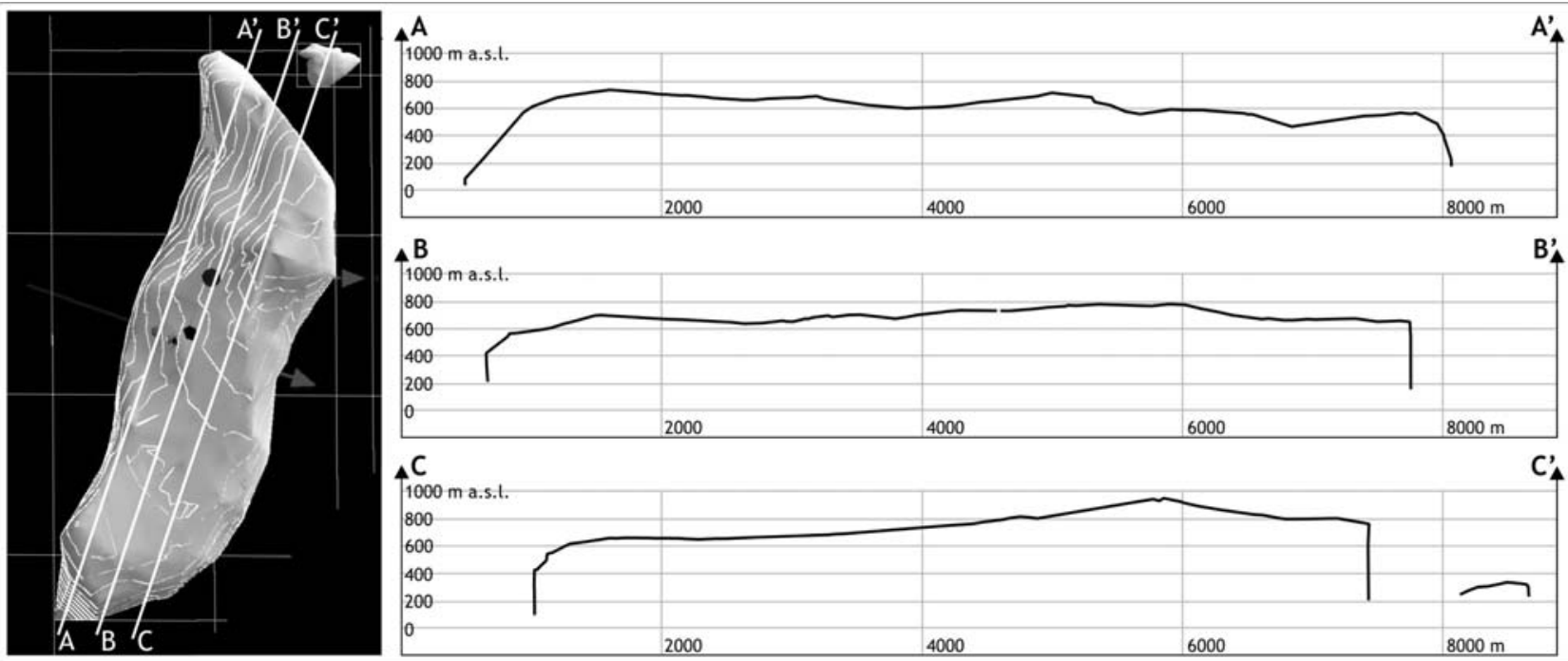

Figure 5.6. Sections along strike through the three-dimensional model in Figure 5.4. The location of the sections $A-A$, $B-B^{\prime}$, and $C-C^{\prime}$ is marked in the map view on the right. All three sections demonstrate the relatively flat roof of the Slaufrudalur Pluton. In addition, Section $A$-A' shows the structural low of the roof in the north-western part. The structural high around Skeggtindar $864 \mathrm{~m}$ a.s.l. and 954 $m$ a.s.l. is recognisable in Section $B-B$, and particularly in Section $C-C$. The northern termination of the pluton in $B-B^{\prime}$ and $C-C$ is controlled by the fault zone described above. In addition $C-C$ shows a section through the small granite intrusion at Gjádalur and its relationship to the main Slaufrudalur Pluton.

For the roof reconstruction in the areas where the roof rock was eroded, we used higher, but most likely below $200 \mathrm{~m}$ judging from the exposures in Slaufrudalur and the upper Gjádalur.

\subsubsection{Interpretation \& Discussion:}

Implications for the mode of emplacement

According to Cargill et al. (1928), the Slaufrudalur Pluton was emplaced by cauldron subsidence (floor subsidence) as originally envisaged by Clough et al. (1909). Cargill et al. (1928) based their interpretation on their observations of the steep, discordant wall contact, the relatively flat roof contact, and the absence of large volumes of country-rock xenoliths. Beswick (1965) and Carmody (1991) took up the concept of cauldron subsidence and corroborated it by their more detailed 
analyses of the internal, subhorizontal layering (see above) that pleads for an incremental subsidence of the pluton floor accommodated by the successive intrusion of small volumes of magma into the pluton. Compositional layering is a feature that has been reported for numerous plutons that have been interpreted to be emplaced by cauldron subsidence, e.g. the Northern Ring Complex in the Nuanetsi Igneous Province, Rhodesia (Stillman, 1970), and the Rallier-du-Baty Complex, Kerguelen Archipelago, Indian Ocean (Bonini et al., 2004).

Reconstruction of the three-dimensional shape of the Slaufrudalur Pluton substantiates the conclusions made by Cargill et al. (1928), Beswick (1965), and Carmody (1991). The three-dimensional pluton model (Fig. 5.3) shows even clearer than pure field observations the discordant nature of the subvertical walls and the
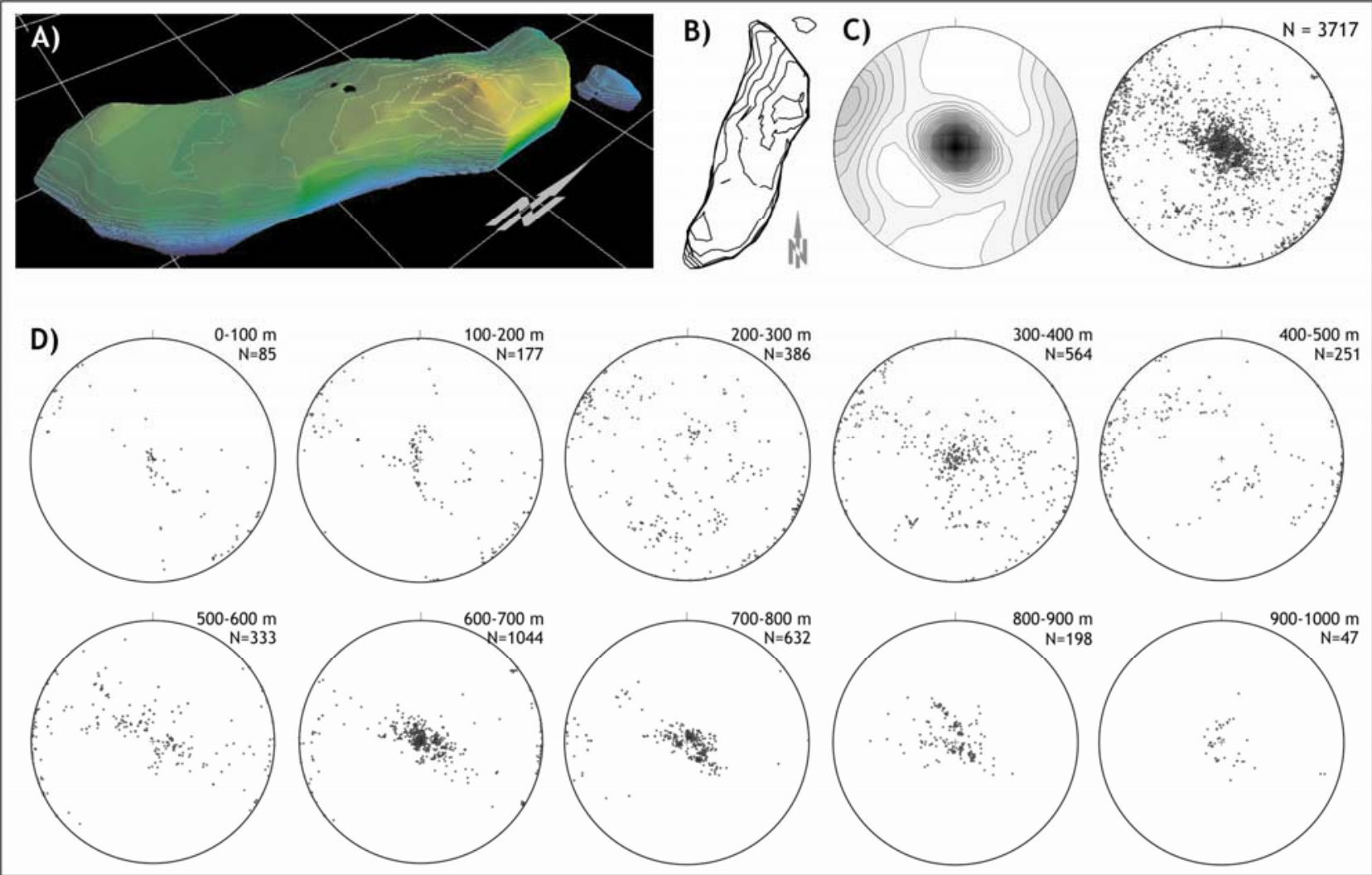

Figure 5.7. Orientation of the surfaces of the three-dimensional model in Figure 5.4. A) Perspective view of the model with elevation contours (spacing $50 \mathrm{~m}$ ). The model surface consists of triangular elements, the orientation of which is plotted in the diagrams in $C$ and D. B) Map view of the elevation contours with a spacing of $100 \mathrm{~m}$. C) Stereographic projection of poles to planes of all 3717 surface elements displayed as density contours (maximum density 1382; minimum density 17) and of all data points on an equal-area stereonet, lower hemisphere. The overall scarcity of intermediate-dipping surfaces underlines the abrupt transition from walls to roof of the pluton. D) Stereographic projection of poles to planes for different elevation intervals. The number of data points for each interval depends on the number of surface elements at that level of the model. The subhorizontal surfaces below $400 \mathrm{~m}$ a.s.l. belong to the small intrusion at Gjádalur. 
overall geometry of the roof. Such features, namely the lack of any significant lateral or upward distortion of a pluton's host rock, are, according to Myers (1975), characteristic of cauldron subsidence. In addition, a "bell-jar" shape is generally accepted as distinctive mark of a pluton emplaced by cauldron subsidence (Roberts, 1970), e.g. the type example of a "bell-jar" intrusion in Limoen Fontein, South Africa (du Toit, 1920). Furthermore, Cruden and McCaffrey (2001) propose that piston-like floor subsidence accompanied by magma addition from the top down results in belljar geometry of the pluton, a model that is in agreement with the observations from Slaufrudalur.

Nevertheless, there is also evidence against cauldron subsidence as the emplacement mechanism for the Slaufrudalur: the lack of shear indicators on the pluton walls; the occurrence of breccias only along the north-eastern and south-western terminations of the pluton; and the map-view shape of the pluton, which is not elliptical as would be expected for a ring fracture surrounding a cauldron. The latter can be explained by the influence of pre-existing structures, since the long axis of the Slaufrudalur Pluton is parallel to the trend of a regional dyke and fissure swarm in the area (Walker, 1974; Torfason, 1979). Furthermore, Torfason (1979) disagreed with the concept of cauldron subsidence as the mechanism controlling the emplacement of the Slaufrudalur Pluton, because the roof geometry does not show the typical "bell-jar" geometry. This, however, can be explained by the influence of the structure of the overlying basalt. Carmody (1991) reported that the roof of the Slaufrudalur Pluton is composed of a single, particularly thick and competent lava flow, which arrested the upwardpropagation of the ring fracture bounding the subsiding cauldron. Hence, the structure of the pluton roof was probably initially entirely flat within the limits of the smoothness of the roof rock. On pluton-scale, this is still the case as demonstrated by the three-dimensional model presented in this paper. However, the model also shows a convex shape in the roof centre superimposed on its flat overall geometry. To use the term "dome", as used by Beswick (1965) is, however, not appropriate and misleading, since it implies an uplift of the overlying basalts. As described above, the roof rocks do not show evidence for uplift, but are concordantly underlain by the pluton, except where steps and cuspate indentations occur. Since these roof features are accompanied by roof faulting, roof pendants, and displaced xenoliths (Figs. $5.2 \& 5.3)$, we interpret these outcrop-scale irregularities of the roof contact as signs of magmatic stoping that was obviously most effective in the central part of the pluton roof (cf. Figs. 5.3). Those parts of the three-dimensional model that include the irregularities and field observations show that stoping acted at a scale from decimetres to tens-of-metres, which is at least one order of magnitude smaller than the space created by cauldron subsidence in this case. A more detailed characterisation of the features and magnitude 
of stoping in the Slaufrudalur Pluton lies beyond the scope of this paper (see Section $5.2)$.

\subsubsection{Discussion}

In the vigorous debate concerning the mechanisms controlling the emplacement of granitic plutons, the construction of threedimensional models of the shape of plutons has been used more and more as a technique to visualise the process of magma emplacement and to verify proposed interpretations of the emplacement mechanisms for certain plutons (e.g. McCaffrey, 1992; Jacques and Reavy, 1994; Koukoukevlas et al., 1996). In general, a better understanding of the threedimensional shapes of plutons contributes to our knowledge of pluton-emplacement mechanisms, particularly in the third and fourth dimensions, i.e. depth, and time (Hogan et al., 1998; Rosenberg et al., 1995; Ameglio and Vigneresse, 1999). However, since the exposure of most plutons is limited to two dimensions, reconstruction of their three-dimensional shapes is generally difficult. Thus, the knowledge of the actual three-dimensional shape and structure of plutons is rather limited (John, 1988; Vigneresse, 1990; Pitcher, 1993).

Only a handful of examples exist where the exposure is good enough to allow a threedimensional reconstruction from field observations, e.g. in tilted plutons, e.g. the Klamath Mountains intrusions, California (Barnes et al., 1986); and the Bergell Pluton, Italy (Rosenberg et al., 1995).
Other examples, where the shape of the pluton is revealed by topography include e.g. granite plutons in South Greenland (Bridgwater et al., 1974) and the Manaslu Leucogranite, Himalaya (Le Fort, 1981) or the Torres del Paine Laccolith, Chile (Michel et al., 2008). In most other cases, the shape of a pluton at depth can be derived from extrapolating field observations of magmatic structures inside the pluton (foliation, lineation, compositional zoning/contacts etc.); temperature and pressure conditions in the contact aureole; shape and orientation of the contact between pluton and wall rock; and deformation structures in the host rock (Paterson and Tobisch, 1988). However, field observations alone are often too limited to delineate the three-dimensional shape of a pluton (see review by Ameglio and Vigneresse, 1999). In addition, measurements of the anisotropy of magnetic susceptibility (AMS) have been proven helpful for the determination of the path of magma emplacement, which can be used to extrapolate three-dimensional models of the mechanisms of emplacement (Hutton et al., 1990; Bouillin et al., 1993; Leblanc et al., 1996; Anma, 1997; Archanjo et al., 1998).

A different approach is the use of gravity inversion. This method uses the gravity anomaly caused by the density contrast between a granitic body and the surrounding rocks. A set of twodimensional gravity profiles is combined in a three-dimensional iterative procedure of gravity-data inversion to deduce the underground extend and shape of the 
pluton (Cordell and Henderson, 1968; Vigneresse, 1990; see also review by Ameglio and Vigneresse, 1999). Examples where this method has been successfully applied include the Twin Peaks volcanic center, Utah (Carrier and Chapman, 1981); the Sidobre Granite Massif, France (Ameglio et al., 1994); and the Linglong Granitic Complex, China (Zeng et al., 2000).

The approach presented in this paper, that is, to use GPS mapping as a basis for a three-dimensional reconstruction, has to our knowledge only once been attempted before by Strzerzynski et al. (2005), who modelled the underground threedimensional geometry of three granite plutons in the Pelvoux Massif, French Alps, on the basis of structural field studies and topography. From the results, they were able to reconstruct the mode of emplacement of the three plutons.

For the Slaufrudalur Pluton, the reconstruction of its three-dimensional shape from GPS mapping certainly yielded extremely good results (Fig. 5.3), that allow us to draw conclusions about the emplacement mechanisms of the pluton proposed by Cargill et al. (1928), Beswick (1965), and Carmody (1991) (see above). However, the reconstruction of the pluton shape from GPS mapping generally requires extraordinarily good exposures along several accessible sections through a pluton, which is seldom realised. The exposure conditions constrain the achievable resolution of the threedimensional model. For the Slaufrudalur Pluton, for which the exposures are excellent and very well distributed throughout the volume of the pluton, the accuracy of the three-dimensional model is in the range of $10^{1}$ to $10^{2} \mathrm{~m}$. This is comparable to a precision of $10-15 \%$ for depth resolution of the gravity inversion method (Ameglio et al., 1997). However, field observations of the Slaufrudalur Pluton have shown that magmatic stoping acted on a scale of $10^{0}$ to $10^{1} \mathrm{~m}$ and is, thus, mostly not resolvable by the threedimensional model. Hence, the reconstruction of a pluton's shape from GPS mapping can only give information about emplacement mechanisms acting on larger scale, depending on exposure conditions. Direct field studies of the structural features of the contact between pluton and host rock, especially the roof contact (Paterson and Fowler, 1993) and in its vicinity (Paterson and Tobisch, 1988), are, therefore, absolutely necessary to constrain concepts of the mode of emplacement of a pluton derived from its three-dimensional shape and to analyse the role of materialtransfer processes acting on a smaller scale. Our interpretation of the mechanisms controlling the emplacement of the Slaufrudalur Pluton, namely cauldron subsidence and magmatic stoping, is similar to emplacement models for other granite plutons in the upper brittle crust, for example the Northern Ring Complex, Nuanetsi Igneous Complex, Rhodesia (Stillman, 1970); several plutons of the Coastal Batholith, Peru (Myers, 1975); a large part of the Sausfjellet Pluton, Norway (Dumond et al., 2005); the Chita Pluton, Argentina (Yoshinubo et al., 2003); 
and the Rallier-du-Baty Ring Complex, Kerguelen Archipelago (Bonini et al., 2004). These and other examples indicate that cauldron subsidence and stoping are common material-transfer mechanisms, which acted together during the emplacement of magmas in the upper brittle crust. Cauldron subsidence creates pistonshaped plutons with steep walls and flat roofs on kilometre-scale, whereas stoping is a secondary process, which reshapes the contact between pluton and host rock on a scale from centimetres to a few hundred metres. The Slaufrudalur Pluton is an impressive example of this.

\subsubsection{Conclusions}

We reconstructed the three-dimensional shape of the Slaufrudalur Pluton in Southeast Iceland using detailed GPS mapping and field studies. The elongated granite body is characterised by subvertical walls and a flat roof with an outcrop-scale step-like pattern. The reconstruction of the three-dimensional pluton shape, together with field observations, served as a basis for our interpretation of the mechanisms controlling the emplacement of the Slaufrudalur Pluton. We believe that the main volume of the main intrusive body was emplaced by incremental cauldron subsidence along subvertical faults, parallel to the main fissure swarms of the Tertiary rift zone. Incremental floor subsidence, accommodated by successive events of magma intrusion, resulted in the formation of a subhorizontal compositional layering within the pluton. The flat roof is the result of emplacement parallel to the layering of the originally sub-horizontal flood basalts. After the main intrusion, the pluton roof was subsequently modified by magmatic stoping.

We therefore conclude that the reconstruction of the three-dimensional shape of the Slaufrudalur Pluton helps to constrain concepts on its mode of emplacement - mainly on the scale of hundreds of metres to kilometres. For the evaluation of the smaller-scale materialtransfer process of magmatic stoping, the accuracy of our three-dimensional model is mostly not sufficient. Hence, careful field observations are necessary to estimate the role of stoping and to constrain the conclusions deduced from the threedimensional model.

\subsubsection{References}

Ameglio, L., Vigneresse, J.-L., 1999. Geophysical imaging of the shape of granitic intrusions at depth: a review. In: Castro, A., Fernández, C., Vigneresse, J.-L. (eds.), Understanding Granites: Integrating New and Classical Techniques. Geological Society of London Special Publications 168, 39-54.

Ameglio, L., Vigneresse, J.-L., Bouchez, J. L., 1997. Granite pluton geometry and emplacement mode inferred from combined fabric and gravity data. In: Bouchez, J. L., Hutton, D. H. W., Stephens, W. E. (eds.). Granite: From Segregation of Melt to Emplacement Fabrics. Kluwer Academic Publishers, Dordrecht, 199-214.

Ameglio, L., Vigneresse, J.-L., Darrozes, J., Bouchez, J. L., 1994. Shape of the Sidobre Granite Massif (Montagne Noire, France) Sensitivity to gravimetric data inversion to density contast. Comptes Rendus de l'Academie des Sciences Serie II 319, 1183-1190. 
Anma, R., 1997. Oblique dispirism of the Yakushima granite in the Ryukyu arc, Japan. In: Bouchez, J. L., Hutton, D. H. W., Stephens, W. E. (eds.). Granite: From Segregation of Melt to Emplacement Fabrics. Kluwer Academic Publishers, Dordrecht, 295-318.

Archanjo, C. J., Macedo, J. W. P., Galindo, A. C., araujo, M. G. S., 1998. Brasiliano crustal extension and emplacement fabrics of the mangerite-charnockite pluton of Umarizal, North-east Brazil. Precambrian Research 87, 1932.

Barnes, C. G., Rice, J. M., Gribble, R. F., 1986. Tilted plutons in the Klamath Mountains of California and Oregon. Journal of Geophysical Research 91, 6059-6071.

Beswick, A. E., 1965. A study of the Slaufrudalur granophyre intrusion, South-East Iceland. Ph.D. Thesis, Imperial College, London, 284 pp.

Bonini, B., Ethien, R., Gerbe, M. C., Cottin, J. Y., Feraud, G., Gagnevin, D., Giret, A., Michon, G., Moine, B., 2004. The Neogene to Recent Rallierdu-Baty nested ring complex, Kerguelen Archipelago (TAAF, Indian Ocean): stratigraphy revisited, implications for caudron subsidence mechanisms. In: Breitkreuz, C., Petford, N. (eds.). Physical Geology of High-Level Magmatic Systems. Geological Society of London Special Publications 234, 125-149.

Bouillin, J. P., Bouchez, J. L., Lespinasse, P., Pecher, A., 1993. Granite emplacement in an extensional setting: an AMS study of the magnetic structures of the Monte Capanne (Elba, Italy). Earth and Planetary Science Letters 118, 263-279.

Bridgwater, D., Sutton, J., Watterson, J., 1974. Crustal downfolding associated with igneous activity. Tectonophysics 21, 57-77.

Burchardt, S., 2006. Volcano-tectonic evolution of the Geitafell Volcano, Southeast Iceland. Diploma Thesis, University of Göttingen, Göttingen, 165 pp.

Cargill, H. K., Hawkes, L., Ledeboer, J. A., 1928. The major intrusions of south-eastern Iceland. Quarterly Journal of the Geological Society of London 84, 505-539.
Carmody, R. W., 1991. The Slaufrudalur stock of southeast Iceland: Geology, Geochemistry and Petrogenesis. Ph.D. Thesis, Johns Hopkins University, Baltimore, 392 pp.

Carrier, D. L., Chapman, D. S., 1981. Gravity and thermal models of the Twin Peaks silicic volcanic center, southwestern Utah. Journal of Geophysical Research 86, 10287-10302.

Clough, C. T. Brantwood Maufe, H., Battersby Bailey, E., 1909. The cauldron-subsidence of Glen Coe, and the associated igneous phenomena. Quarterly Journal of the Geological Society, London 65, 611-678.

Cordell, L., Henderson, R. G., 1968. Iterative threedimensional solution of gravity anomaly using a digital computer: Geophysics 33, 596-601.

Cruden, A. R., 1998. On the emplacement of tabular granites. Journal of the Geological Society 155, 853-862.

Cruden, A. R., McCaffrey, J. W., 2001. Growth of plutons by floor subsidence: implications for rates of emplacement, intrusion spacing and melt-extraction mechanisms. Physics and Chemistry of the Earth 26, 303-315.

Dumond, G., Yoshinubo, A. S., Barnes, C. G., 2005. Midcrustal emplacement of the Sjausfjellet pluton, central Norway: Ductile flow, stoping, and in situ assimilation. Geological Society of America Bulletin 117, 383-395.

Du Toit, A. L., 1920. The Karoo dolerites of S. Africa: a study in hypabyssal injection. Transactions of the Geological Society of Africa $23,1-42$.

Gale, N. H., Moorbath, S., Simons, J., and Walker, G. P. L., 1966. K-Ar ages of acid intrusive rocks from Iceland. Earth and Planetary Science Letters 1, 284-288.

Hogan, J. P., Price, J. D., Gilbert, M. C., 1998. Magma traps and driving pressure: consequences for pluton shape and emplacement in an extensional regime. Journal of Structural Geology, 20, 1155-1168.

Hutton, D. H. W., Brown, P. E., Becker, S. D., 1990. A new mechanism of granite emplacement: intrusion in active extensional shear zones. Nature 343, 452-455. 
Jacques, J. M., Reavy, R. J., 1994. Caledonian plutonism and major lineaments in the SW Scottish Highlands. Journal of the Geological Society of London 151, 955-970.

John, B. E., 1988. Structural reconstruction and zonation of a tilted mid-crustal magma chamber: The felsic Chemehuevi Mountains plutonic suite. Geology 16, 613-617.

Koukouklevas, L., Pe-Piper, G., Piper, D. J. W., 1996. Pluton emplacement by wall-rock thrusting, hanging-wall translation and extensional collapse: latest Devonian plutons of the Cobequid fault zone, Nova Scotia, Canada. Geological Magazine 133, 285-298.

Leblanc, D., Gleizes, G., Roux, L., Bouchez, J. L., 1996. Variscan dextral transpression in the French Pyrenees: new data from the Pic de Trois-Seigneurs granodiorite and its country rocks. Tectonophysics 261, 331-345.

Le Fort, P., 1981. Manaslu leucogranite: a collision signature of the Himalaya and a model for its genesis and emplacement. Journal of Geophysical Research - Solid Earth 86, 10 545-10 568.

McCaffrey, K. J. W., 1992. Igneous emplacement in a transpressive shear zone: Ox Mountains igneous complex. Journal of the Geological Society of London 149, 221-235.

Michel, J., Baumgartner, L., Putlitz, B., Schaltegger, U., Ovtcharova, M., 2008. Incremental growth of the Patagonian Torres del Paine laccolith over 90 k.y. Geology 36, 459-462.

Myers, J. S., 1975. Cauldron subsidence and fluidization: Mechanisms of Intrusion of the Coastal Batholith of Peru into its own volcanic ejecta. Geological Society of America Bulletin 86, 1209-1220.

Paterson, S. R., Fowler, T. K., Jr., 1993. Reexamining pluton emplacement processes. Journal of Structural Geology 15, 191-206.
Paterson, S. R., Tobisch, O. T., 1988. Using pluton ages to date regional deformations: Problems with commonly used criteria. Geology 16, 11081111.

Pitcher, W. S., 1993. The Nature and Origin of Granite. Chapman \& Hall, London, 321 pp.

Roberts, J. L., 1970. The intrusion of magma into brittle rocks. In: Newall, G., Rast, N. (eds.), Mechanism of Igneous Intrusion. Geological Journal Special Issues 2, 287-338.

Rosenberg, C. L., Berger, A., Schmid, S. M., 1995. Observations from the floor of a granitoid pluton: Inferences on the driving force of final emplacement. Geology 23, 443-446.

Stillman, C. J., 1970. Structure and evolution of the Northern Ring Complex, Nuanetsi Igneous Province, Rhodesia. In: Newall, G., Rast, N. (eds.). Mechanism of Igneous Intrusion. Geological Journal Special Issues 2, 33-48.

Strzerzynski, P., Guillot, S., Courrioux, G., Ledru, P., 2005. 3D geometrical modeling of Stephanian granite from the Pelvoux Massif (French Alps). Comptes Rendus Geoscience 337, 1284-1292.

Torfason, H., 1979. Investigations into the structure of south-eastern Iceland. Ph.D. Thesis, University of Liverpool, Liverpool, 589 p.

Vigneresse, J.-L., 1990. Use and misuse of geophysical data to determine the shape at depth of granitic intrusions. Geological Journal 25, 249-260.

Walker, G. P. L., 1974. The structure of eastern Iceland. In: Kristiansson, L. (ed.), Geodynamics of Iceland and the North Atlantic Area. Reidel, Dordrecht, 177-188.

Zeng, H., Wan, T., Teyssier, C., Yao, C., Tikoff, B., 2000. Case History. The 3-D geometry of the Linglong granitic complex from 2-D gravity forward modeling, Shandong Province, east China. Geophysics 65, 421-425. 
5.2 Interplay between different mechanisms controlling the emplacement of the Slaufrudalur Pluton, Southeast Iceland

\begin{abstract}
The Slaufrudalur Pluton is the largest granitic intrusion in Iceland and may be among the best exposed plutons worldwide. Five glacial valleys cut sections through the uppermost 900 $\mathrm{m}$ of the pluton, exposing its three-dimensional shape and the contact between pluton and basaltic host rock. The wall contacts are subvertical and sharp. Only in the northeast and southwest is the wall contact characterised by brittle faulting. The pluton roof is smooth on map scale, so that the overall cross-sectional shape of the pluton and its internal layering indicate emplacement by incremental cauldron subsidence/floor sinking. The nature and orientation of the wall contacts shed light on the kinematics of ring-faulting before subsidence of the pluton floor began. A pronounced elongation of the pluton parallel to the trend of regional fissure swarms indicates strong tectonic control of horizontal ring-fault propagation, whereas faulted wall contacts represent step-over structures between the earlier-formed ring faults. On outcrop scale, the roof contact, which originally exploited the layering of the basaltic host rock, exhibits numerous steps, faults, and apophyses; these are interpreted as signs of magmatic stoping that was caused by internal magma pressure and ancillary thermal shock, faulting due to regional extension and gravity, and dyking. Based on our knowledge of the three-dimensional shape of the pluton and its roof structure, we estimate that around $30 \%$ of the exposed volume of the pluton ( 8 to $10 \mathrm{~km}^{3}$ ) was emplaced by magmatic stoping.

The Slaufrudalur Pluton was never the root of one of the Tertiary volcanoes exposed in Southeast Iceland. Instead, it was a long-lived intrusion associated with the nearby Vesturhorn Volcano, with which it shared a common, magma source at depth.
\end{abstract}

\title{
5.2.1 Introduction
}

The interplay of multiple emplacement mechanisms of magma (Paterson and Fowler, 1993) has been documented for many plutons worldwide. For the upper crust, the main mechanisms that control the emplacement of plutons are roof uplift, floor sinking (Cruden and McCaffrey, 2001), and magmatic stoping (e.g. Paterson and Fowler, 1993; Zak et al., 2006). Especially the process and role of magma- tic stoping has been debated from the very early stages of research of granite emplacement (e.g. Goodchild, 1892; Daly, 1903) to present (Glazner and Bartley, 2006, 2008; Clarke and Erdmann, 2008; Paterson et al., 2008; Yoshinobu and Barnes, 2008). The main point of controversy is the quantitative contribu-tion of stoping towards space creation. Other problems related to stoping are to 
understand the mechanism by which blocks of roof rock are dislodged and what happens to the stoped blocks, since large accumulations of xenolithic material are rarely observed (e.g. Zak et al., 2006). Unfortunately, in most cases, it is difficult to evaluate the volumetric contribution of individual emplacement mechanisms to the total amount of space created, due to limited exposures. However, three-dimensional exposures of the Slaufrudalur Pluton, Southeast Iceland, make it one of the rare exceptions. A detailed study of the structures that characterise the contact between pluton and basaltic host rock, as well as high-precision GPS mapping, provide insights into the modes of emplacement of the Slaufrudalur Pluton; namely cauldron subsidence/floor sinking and magmatic stoping. Furthermore, our field observations help us better understand the mechanics of both emplacement processes.

Hence, the aims of this paper are, (1) to give a detailed description of the features of the wall and roof contacts on different scales, (2) to evaluate the mechanisms that controlled the emplacement of the pluton, and (3) to discuss the existence of possible connections between the Slaufrudalur Pluton and its neighbouring intrusive complexes.

\subsubsection{Geological setting}

The Slaufrudalur Pluton belongs to a suite of coeval plutonic complexes in the Lón area in Southeast Iceland, which include the composite complexes of Austurhorn and Vesturhorn, as well as the entirely silicic intrusions of Slaufrudalur and Reydará (Fig. 5.8; Cargill et al., 1928; Furman et al., 1992). They are interpreted as the roots of late Tertiary (6-7 Ma) volcanic centres (Furman et al., 1992). The Slaufrudalur Pluton was emplaced at a depth of around $1 \mathrm{~km}$ (cf. Walker, 1974), into flat-lying basaltic lava flows of the late Tertiary rift zone. K/Ar whole rock ages of the pluton range from $6.5 \pm 0.4 \mathrm{Ma}$ to 10.0 \pm 1.0 Ma (Gale et al., 1966).

The Slaufrudalur Pluton is around $8 \mathrm{~km}$ long, around $2.4 \mathrm{~km}$ wide, and aligned in a NNE-SSW direction (Fig. 5.9). The glacial valleys of Kapaldalur, Endalausidalur, Slaufrudalur, Thorgeirstadadalur, and Gjádalur expose several sections through the uppermost $900 \mathrm{~m}$ of the Slaufrudalur Pluton, including excellent exposures of its roof and wall contacts. Recent GPS mapping of the pluton has shown that Slaufrudalur is a rhomboidal, elongate body with steep walls and a flat roof (Section 5.2; Burchardt et al., 2009). Furthermore, the Slaufrudalur Pluton consists of two separate bodies; the much smaller complex of Gjádalur is separated from the main intrusion by a vertical fault and located approximately $300 \mathrm{~m}$ to the north north-east (Fig. 5.9).

Slaufrudalur was first described in detail by Cargill et al. (1928) and later petrographically and geochemically analysed by Beswick (1965) and Carmody (1991). Based on a fabric classification, Carmody (1991), in concordance with Beswick (1965), distinguishes a complete 
spectrum of rocks between the endmembers microgranite and granophyre.

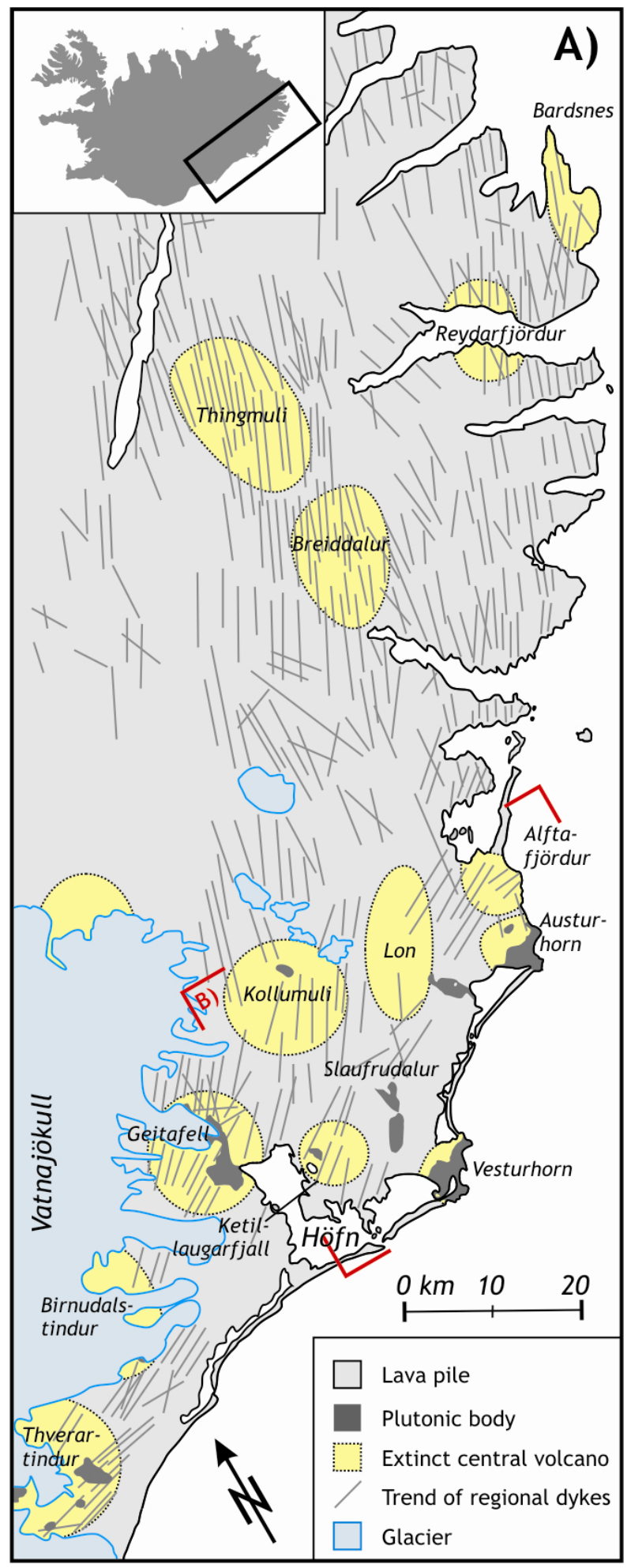

The composition of rocks ranges from granodiorite to granite, which is distributed throughout the pluton in subhorizontal layers (see below). Furthermore, Carmody (1991) distinguishes an Upper and a Lower

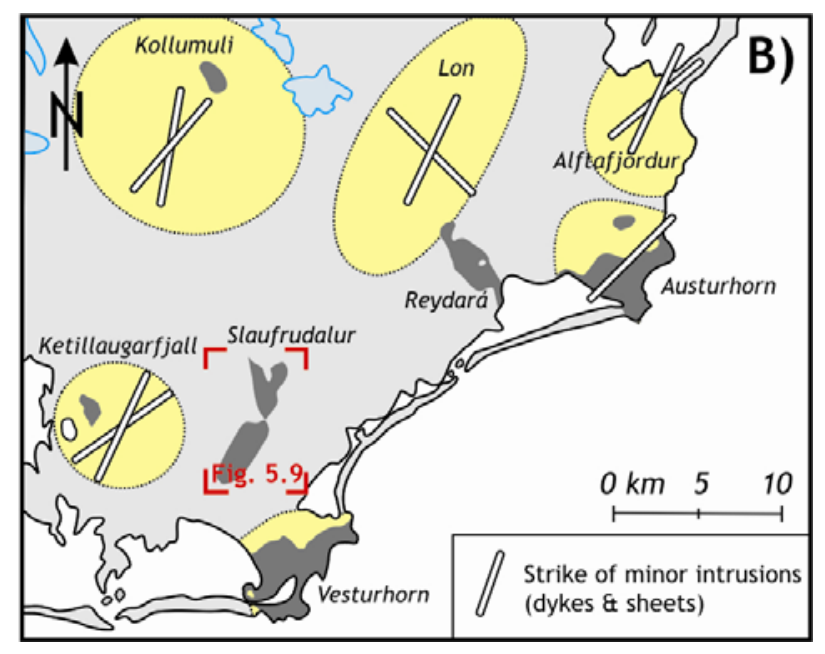

Figure 5.8. A) Schematic tectonic map of Southeast Iceland, modified after Walker (1974) (location shown in inset map). Trend of regional dykes, according to Walker (1974), shows representative values for every $10^{\text {th }}$ dyke. B) Detail tectonic map of the greater Lónsöraefi area (location marked in A), which illustrates the main trends of minor intrusions (dykes, sheets) in the volcanic complexes which surround Slaufrudalur. Data from Kollumuli (n = 760), Lón $(n=162)$, and Ketillaugarfjall ( $n$ $=198$ ) from Torfason (1979); data from Alftafjördur from Blake (1966; $n=216)$ and Paquet et al. (2007; $n=54)$; data from Austurhorn from Furman et al. (1992; trend only given).

Supergroup (USG and LSG) based on mineralogy and geochemistry: Rocks of the USG commonly consist of sodium feldspar, iron amphiboles, clinopyroxenes, and zircon, whereas rocks of the LSG contain anorthite-richer plagioclase, orthoclasericher alkali feldspar, and magnesiumricher amphibole and biotite. The compositional discontinuity between the Upper and Lower SG is thus characterised by high $\mathrm{SiO}_{2}, \mathrm{Na}_{2} \mathrm{O}, \mathrm{FeO}_{\text {total }}, \mathrm{Y}$, and $\mathrm{Zr}$ contents in the USG, while the LSG rocks 
are richer in $\mathrm{Al}_{2} \mathrm{O}_{3}, \mathrm{~K}_{2} \mathrm{O}, \mathrm{MgO}, \mathrm{TiO}_{2}, \mathrm{Rb}$, and V. Carmody (1991) explained these differences with different source rocks. In general, Slaufrudalur rocks are derived from partial melting of hydrated basalt at amphibolite-facies conditions $\left(650-700^{\circ} \mathrm{C}\right)$. Heat for the melting was provided by the intrusion of a large basic magma chamber underlying the area.

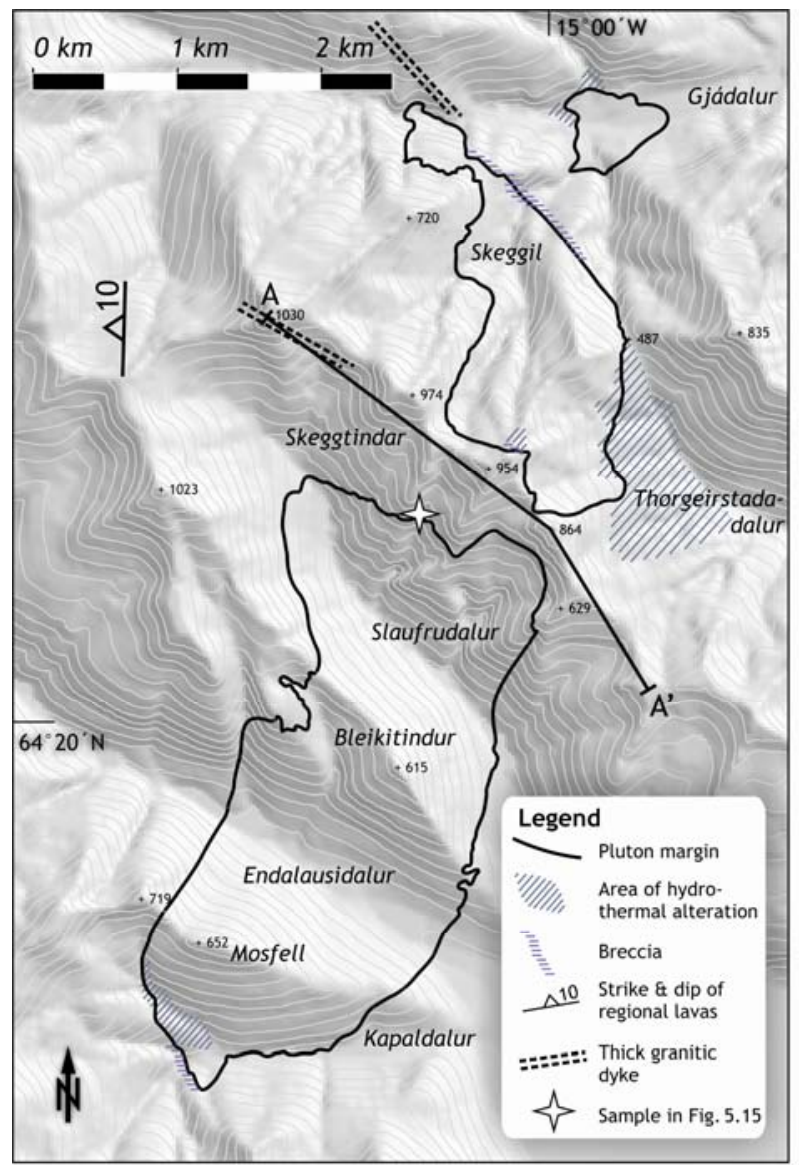

Figure 5.9. Geological map of the Slaufrudalur Pluton with special emphasis on its contact features. The outline of the pluton was mapped with high-resolution GPS. Map is based on the Digital Elevation Model of Iceland (cell size 25 m) provided by the National Land Survey of Iceland. Note the occurrence of breccias along the walls parallel to the short axes of the main plutonic body. Line $A-A$ ' marks the cross section in Figure 5.11.
Cargill et al. (1928) were the first to describe the subhorizontal compositional layering in the Slaufrudalur Pluton. This layering was later studied in detail by Beswick (1965) and Carmody (1991). Both authors tried to map the extent and the geometry of individual units that had been interpreted as sills by Cargill et al. (1928). However, Beswick (1965) and Carmody (1991) could not correlate sequences between different parts of the pluton. Carmody (1991) distinguishes at least 23 individual units, which are characterised by complex structural relationships between each other. Furthermore, she proposed that the geometry of the units is tongue- rather than sill-shaped. From a calculation of the original densities of the different magmas, Carmody (1991) was also able to rule out density stratification as the reason for the compositional layering.

Based on their observations of the shape and the internal structure of the pluton, Cargill et al. (1928) proposed that Slaufrudalur was emplaced by cauldron subsidence. Beswick (1965) agreed with this interpretation based on his observation that the surrounding basalts lack signs of distortion; he concluded that the pluton walls represent an elliptical ring fracture, whereas the roof is a truncating cross fracture that forms a continuation of the ring fracture. Carmody (1991) followed these interpretations and enhanced the emplacement model by a detailed study of the internal layering and the roof of the Slaufrudalur Pluton. She proposed that the roof rock is formed by a particularly thick 
and continuous lava flow that arrested the upward-propagating ring fracture. Further horizontal propagation of the fracture detached one or a few large blocks of country rock, which sank down episodically, as small batches of magma rose along the ring fracture to fill the created space from the top down. Even though Cargill et al. (1928) and Beswick (1965) reported the "step-like" pattern of the roof contact of the pluton, they concluded that magmatic stoping did not play a significant role during emplacement since large volumes of host-rock xenoliths are lacking. Carmody (1991) reported the occurrence of abundant cm-size basaltic xenoliths at the base of individual intrusive units. However, she also proved that the trace element patterns of these xenoliths are distinct from those of the quartz and olivine tholeiites, that represent the host rock of the Slaufrudalur Pluton and are thus, probably derived from magmatic stoping in a large magma chamber underlying the area that produced batches of felsic magma by partial melting of crustal material and fed the Slaufrudalur Pluton.

\subsubsection{Results}

Because our main aim was to understand the mechanisms controlling the emplacement of the Slaufrudalur Pluton, field work focused on a detailed characterisation of contact between pluton and host rock. Using GPS mapping, we also reconstructed the three-dimensional shape of the pluton (Section 5.1; Burchardt et al., 2009), which provides valuable constraints on the largescale material-transfer process cauldron subsidence that created the main volume of the pluton. However, magmatic stoping, present throughout the roof contact and described by Cargill et al. (1928) and Beswick (1965) as "abrupt rises and falls" of the roof, played a significant role during final emplacement on a smaller scale, as will be shown below. In the following, we will give a summary of the field-derived data to interpret the emplacement mechanisms.

\subsubsection{Shape of the Slaufrudalur Pluton on map scale}

In map view, the main body of the Slaufrudalur Pluton has a rhombic shape with a long axis striking $018^{\circ}$ (NNE-SSW) and a short axis striking $146^{\circ}$ (NW-SE) (Figs. $5.9 \& 5.10$ ). The long axis of the main body is $\sim 7.3 \mathrm{~km}$ long; the short axis $\sim 2.4 \mathrm{~km}$. Based on detailed GPS-mapping, Burchardt et al. (2009) reconstructed its three-dimensional shape (Fig. 5.10; Section 5.1). It resembles an elongate rhomboidal body with subvertical walls and a flat roof. Apart from its rhombic shape in map view, it is conspicuous that the contact features of the wall-contacts parallel to the long axes of the pluton differ from those parallel to the short axes. Along the long axes, the subvertical margin truncates the flat-lying basalt lava flows at right angles without any signs of host-rock distortion or translation. In contrast, the wall contacts along the short axes are characterised by the occurrence of basaltic tectonic breccias (see below; Figs. $5.9 \& 5.10$ ). 

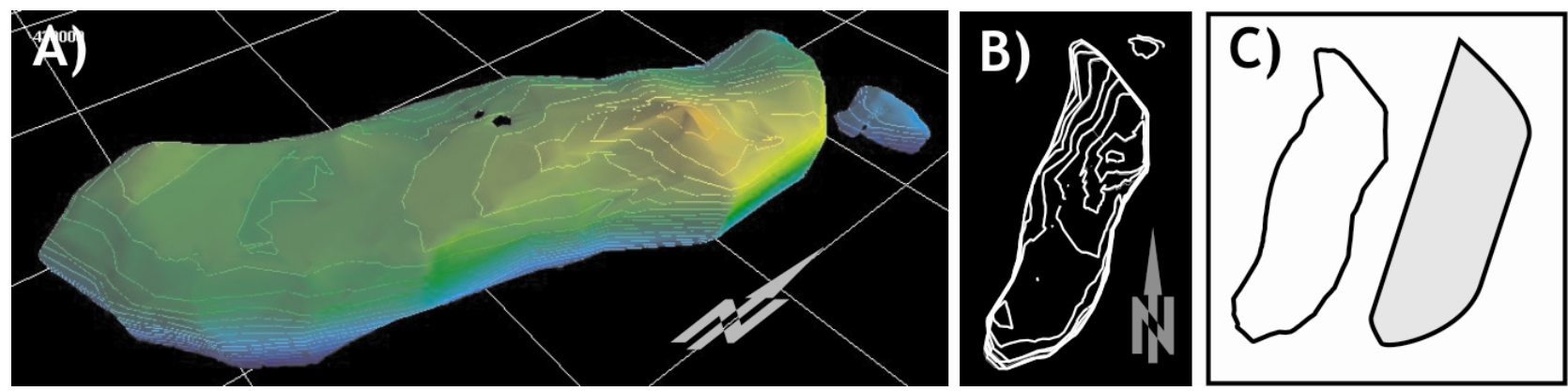

Figure 5.10. A) Perspective view from the southeast of a three-dimensional model of the Slaufrudalur Pluton created from GPS mapping of the outcrop of the contact plane (Section 5.1; Burchardt et al., 2009). Lines on the pluton surface display elevation contours (spacing $100 \mathrm{~m}$ ). The pluton is characterised by steep walls and a relatively flat roof. Grid in the background with $1 \mathrm{~km}$ spacing. B) Map view elevation contours (spacing $100 \mathrm{~m}$ ). C) In map view, the Slaufrudalur pluton has an elongate rhomboidal shape. Simplified mapview shape shown in grey.

\subsubsection{Cross-sectional shape of the}

\section{Slaufrudalur Pluton}

An almost complete cross section through the pluton and the surrounding rocks can be studied below the Skeggtindar Ridge on the northern slope of the Slaufrudalur Valley (Fig. 5.11). The contact below Skeggtindur $629 \mathrm{~m}$ a.s.l. ${ }^{1}$ is subvertical, but changes rapidly to a shallow dip towards the summits. It therefore represents the

\footnotetext{
${ }^{1}$ The peaks of the Skeggtindar Ridge do not have individual names and are labelled on the map only by their elevations above sea level (e.g. $1030 \mathrm{~m}$ a.s.l.). "Skeggtindar" is the plural of "Skeggtindur" with "Tindur" being Icelandic for "peak". The name of an individual peak of the Skeggtindar Ridge is therefore given here as e.g. "Skeggtindur $1030 \mathrm{~m}$ a.s.l."
}

transition from the eastern wall of the pluton to its roof. The roof itself is relatively flat with numerous steps and cuspate indentations. It dips approximately $10^{\circ}$ to the west, which is consistent with the tilting of the Tertiary lava pile within the regional Lagarfljot Flexure Zone in East Iceland (Section 2.2.2; Walker, 1974). The western margin of the pluton in the river in Slaufrudalur is subvertical and complicated by basaltic dykes. The crosssectional shape of the pluton is thus a slightly-tilted dome with steep walls and a flat roof, the transition between both is abrupt within meters.

Apart from the section exposed in the Slaufrudalur Valley, other partial cross sections are exposed in the valleys of Kapaldalur, Endalausidalur, Thorgeirstadadalur, and Gjádalur and on the ridges in between. All these sections exhibit similar features to those in the cross section described above. For example, the transition between roof and wall contact is exposed on the western Bleikitindur Ridge (Fig. 5.12). There, the flat-lying, slightly irregular pluton roof changes into the subvertical wall within a few tens of metres. Again, no signs of wall-rock deformation were observed. Similarly, the western roof contact on the Mosfell Ridge dips at a shallow angle to the west. On the 
ridge crest, the contact is nearly flat-lying and characterised by some cuspate indentations (Fig 5.13B). To the south, a steep dip of the wall contact can be inferred as its trace goes down to the small canyon at the upper end of Kapaldalur. Within the canyon, there is a broad alteration zone along the pluton wall with complex structural relationships between host rock, granite, basaltic xenoliths, and basaltic dykes obscured by strong hydrothermal alteration.
In summary, the walls in all cross sections, i.e., the wall contacts parallel to the long axes of the pluton are subvertical and sharp. The outcrop quality of these contacts is, however, not good enough to identify any shear sense along the pluton wall (cf. Fig. 5.12). Only on the northeastern slope of Bleikitindur is the pluton wall underlain by a thick basaltic lava flow which dips $\sim 35^{\circ} \mathrm{NW}$; on the south-western slope and elsewhere, the margin is subvertical and straight despite few irreg-

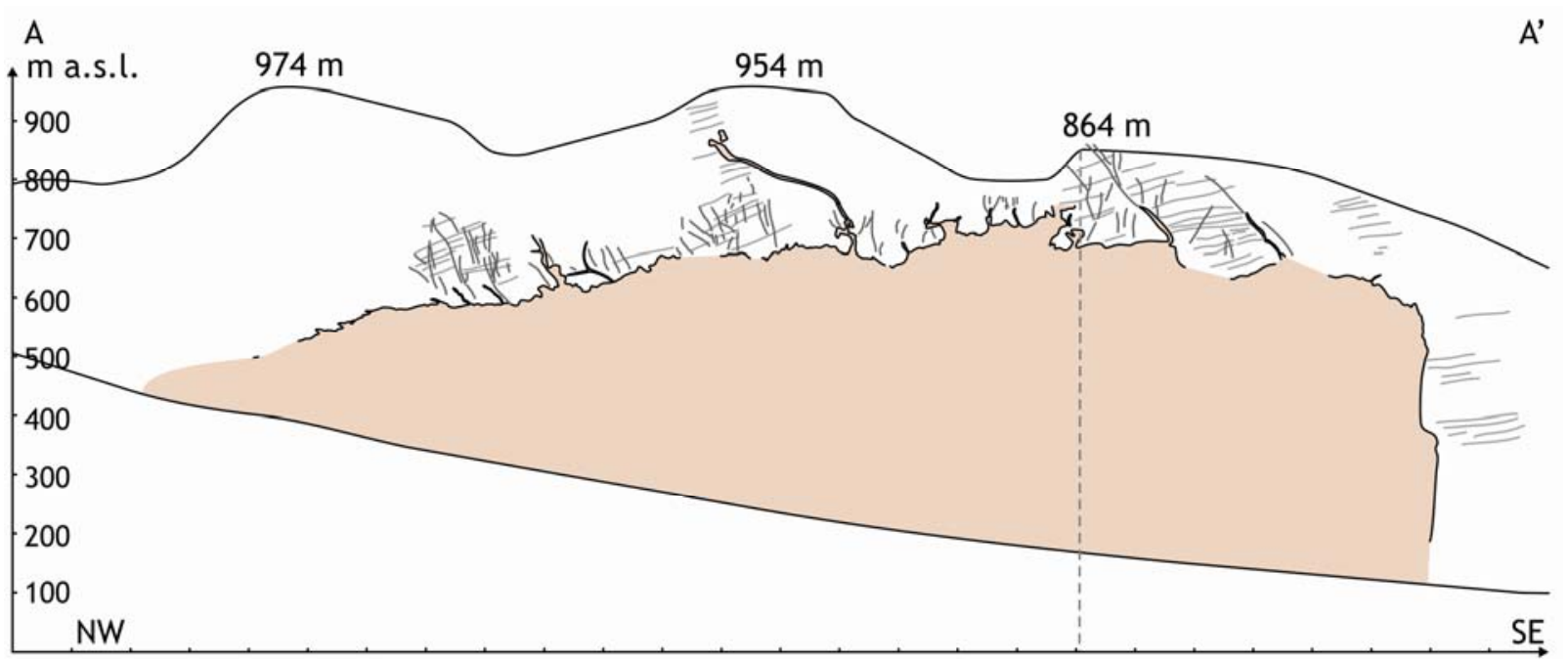

Figure 5.11. Cross section through the Slaufrudalur Pluton exposed on the northern slope of the valley of Slaufrudalur (trace marked in Fig. 5.9; dashed line marks a kink in the profile). Base line corresponds to level of Slaufrudalur Valley. Exposed contact was mapped from field photographs and is marked by a black line. All exposed contact features were projected laterally over a short distance onto the plane of section. Light grey lines represent layering in basaltic host rock. Dark grey lines mark prominent fractures and faults. Note that host-rock and pluton have been tilted by approximately $10^{\circ}$ to the west due to regional dip increase with depth and within the Lagarfljot Flexure Zone (Section 2.2.2; Walker, 1974, Torfason, 1979; cf. Fig. 5.9). ularities which are probably the result of minor intrusions of granitic melt into the host rock.

Sections parallel to the strike of the Slaufrudalur Pluton are exposed for example on the northern slopes of the Skeggtindar Ridge and in the two Skeggil Canyons. Roof exposures exhibit the same step-like pattern as observed in the cross sections (see also Section 5.3.2). In the upper Thorgeirstadadalur and Skeggil Canyons, a broad brittle fault zone ( $\sim 10$ to 30 meters thick) represents the wall contact along the northern wall parallel to the short axis of the main intrusive body. The vertical fault zone strikes $134^{\circ}$ and is 
characterised by an up to $10 \mathrm{~m}$ thick basaltic fault breccia, which is more resistant to weathering than the adjacent rocks and marks the fault along-strike. However, this breccia does not show any indications of shear sense, but instead strong hydrothermal alteration. North of the north-western termination of the pluton, a thick granitic dyke occurs in along-strike projection of the fault.

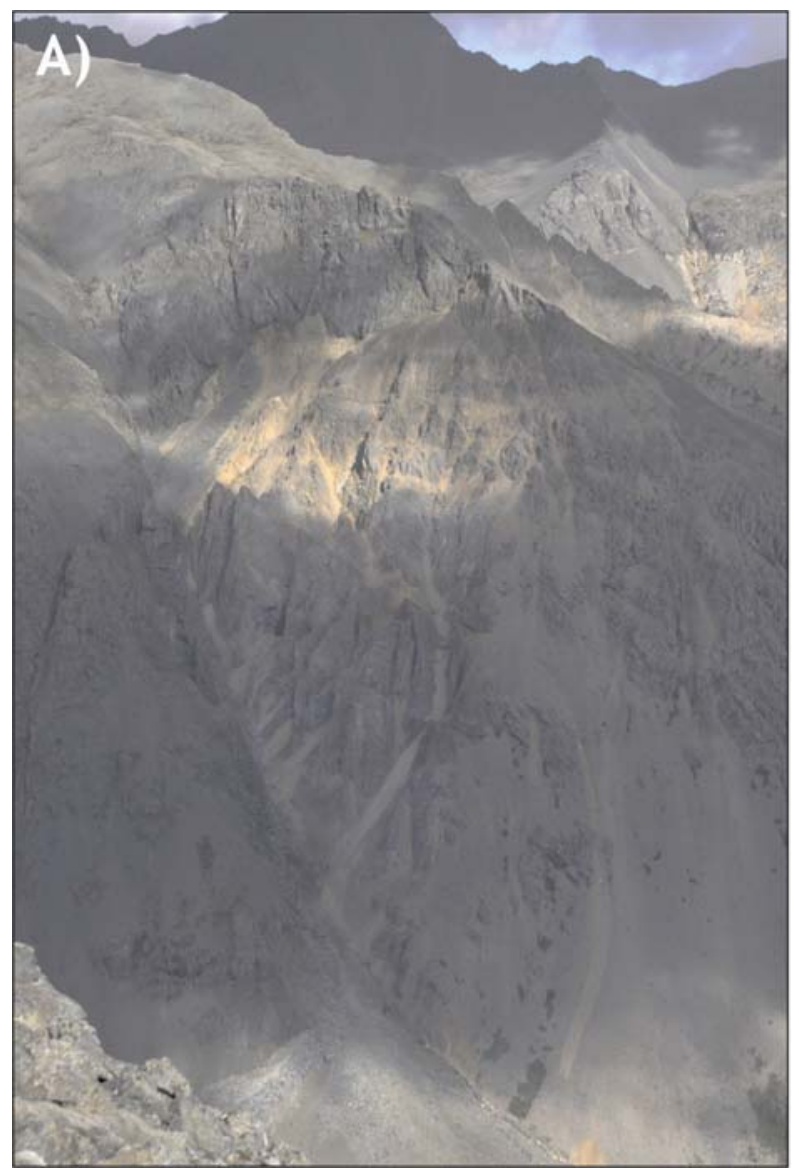

Approximately $300 \mathrm{~m}$ to the north of the fault zone, granite is exposed in Gjádalur. In map view, this outcrop has a circular shape with steeply-dipping margins (Fig. 5.9). Judging from field observations, the Gjádalur granite is not linked at the surface with the rest of the granite body to the south of it; however, its occurrence in direct proximity to the main granite intrusion and the macroscopic resemblance

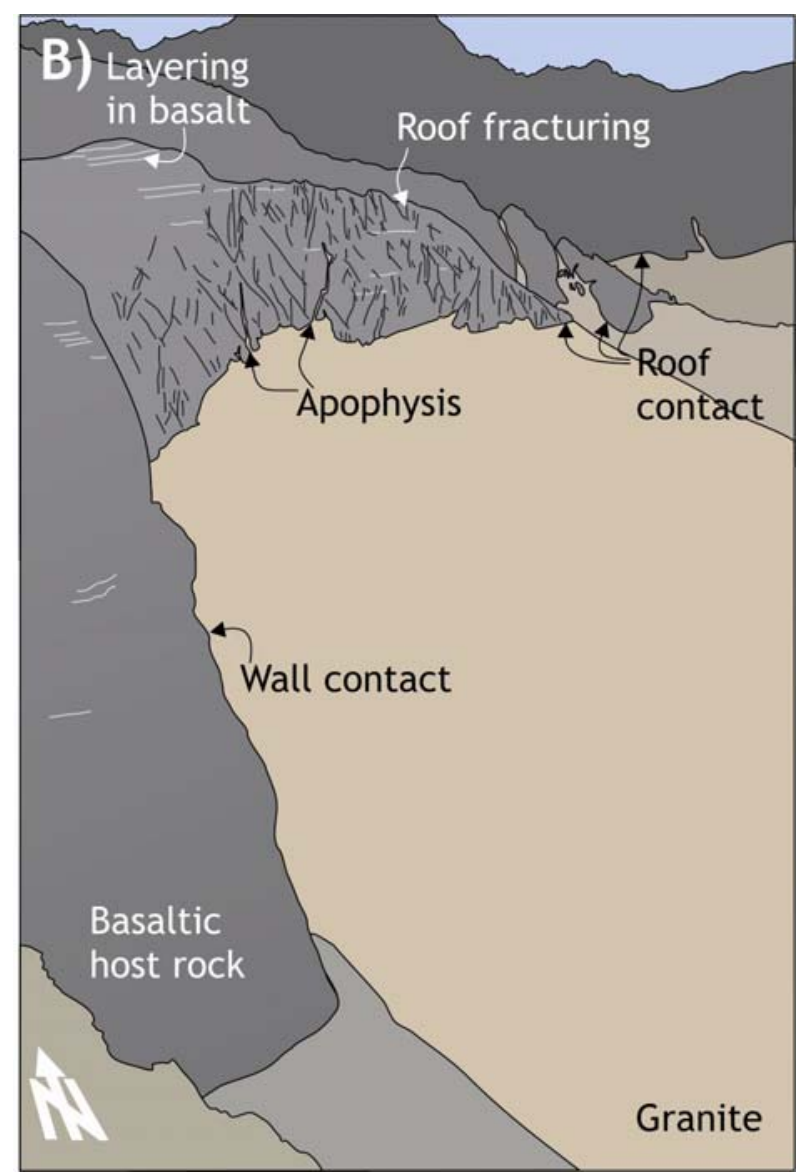

Figure 5.12. A) \& B) View from Mosfell Ridge onto the western part of the Slaufrudalur Pluton exposed on the western Bleikitindur Ridge in Endalausidalur. The exposed thickness of the pluton in this section is around $500 \mathrm{~m}$. The roof contact as exposed in this and other parallel sections in the background is characterised by steps, apophyses, and cuspate indentations. The transition from the more or less horizontal roof to the wall contact is abrupt. Here, the wall contact is eroded and creates a narrow canyon. However, there are no indications for host-rock uplift. Only above the pluton roof is there intense fracturing. 
of the material suggest a genetic link between both intrusions.

Another partial section through the Slaufrudalur Pluton, parallel to its strike direction, is exposed in the upper Kapaldalur. There, the western wall contact parallel to the long axis curves into the short-axial termination of the pluton, which is characterised by strong hydrothermal alteration near the bend and the occurrence of a basaltic breccia that flanks the subvertical pluton wall and includes partly-rounded clasts of various, but mainly basaltic compositions. Its macroscopic appearance is dissimilar to the breccia, which flanks the pluton in the north, but the breccia at Kapaldalur also forms a distinct wall, which is more resistant to weathering than the adjacent rocks and follows the contact and also displays no shear-sense indicators.

\subsubsection{Features of the roof contact}

At map scale, the overall geometry of the roof of the pluton is flat and smooth (Fig. 5.10; Section 5.1; Burchardt et al., 2009). As shown in Figures 5.11 and 5.12, the roof orientation coincides well with the orientation of the layering of the overlying basalt lavas, which do not show any uplift. Carmody (1991) proposed that the first unit belonging to the Slaufrudalur Pluton was injected below a relatively thick lava flow that exploited the subhorizontal layering. However, we could not identify a particular lava flow that served as the roof of the pluton. Instead, on outcrop-scale, the roof contact consists of steps and cuspate indentations with abundant granitic apophyses. There are numerous sections through the pluton roof allowing detailed investigations of the roof structures in different orientations at outcrop scale (Fig. 5.13). In general, the overlying basalts are strongly fractured by two conjugate sets of fractures (Figs. 5.11, $5.12,5.13 \mathrm{~A})$. Faulting along these fractures resulted in a step-like pattern (Fig. 5.13B). On closer inspection, these faults are characterised by brittle deformation in the basaltic roof rock, but exhibit different features when entering the granite, including subsolidus deformation such as ductile flow structures (seldom), brittle deformation (in some cases), or no indication for deformation at all (most cases). In addition, several faults were intruded by granitic apophyses that range in thickness from a few centimetres to a few metres (Fig. 5.13C; E). The apophyses show a preferred alignment along the Edipping set of the fractures (cf. Fig. 5.11). Furthermore, the dykes never reach very far into the overlying host rock, except in the case of a thick, multiple dyke that cuts the peak of Skeggtindur $1030 \mathrm{~m}$ a.s.l. Only a few apophyses are not associated with roof faulting (Fig. 5.13D). Furthermore, some injections of granitic melt into the roof rocks are characterised by complex combinations of concordant (sill) and discordant (dyke) geometries (Fig. 5.13F), in some cases leading to the partial or complete separation of roof rocks as roof pendants (Fig. 5.13G) or xenolithic blocks (Fig. 5.13H). In addition, there are abundant granitic veins of a few centi- 

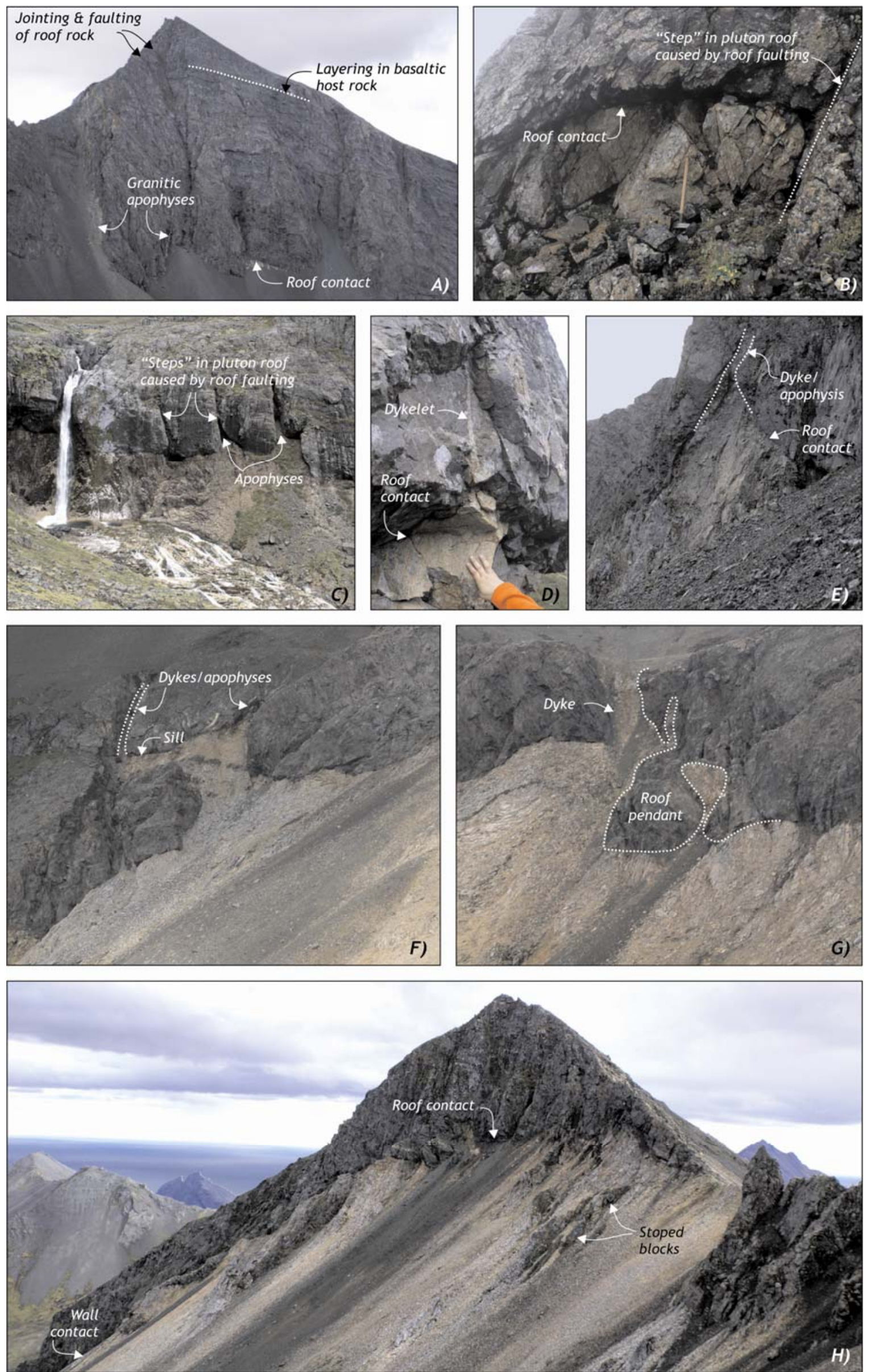
Figure 5.13. Compilation of field photographs that show some features of the roof contact of the Slaufrudalur Pluton. A) Roof rock fracturing and faulting above the pluton roof (covered by scree in the lower part) in Skeggtindur $974 \mathrm{~m}$ a.s.l. View SW. Thickness of individual lava flows is around $5 \mathrm{~m}$. B) Offset in the pluton roof caused by faulting of the overlying basalts in an outcrop on the $N W^{\prime}$ Bleikitindur ridge. Displacement of the footwall-block (to the right) is around $1.5 \mathrm{~m}$. View WSW. Hammer is about $0.5 \mathrm{~m}$ long. C) "Steps" and related apophyses in the pluton roof in upper Gjádalur. View NW. Kvosafoss waterfall is approximately $10 \mathrm{~m}$ high. D) Small granitic apophysis in the roof of the Slaufrudalur intrusion $W$ of Skeggil. The apophysis is not associated with the occurrence of a roof fault. E) Dyke injected from the roof of the Slaufrudalur Pluton along a fault into the overlying basalts $W$ of Skeggtindur $954 \mathrm{~m}$ a.s.l. The dyke is less than $1 \mathrm{~m}$ thick. View SW. F) Cuspate indentation in the roof of the Slaufrudalur Pluton, $S$ of Skeggtindur $954 \mathrm{~m}$ a.s.l., which resulted from dyke and sill injection into the overlying basalt, preferably along the subhorizontal bedding plane. View NNW. The sill is around $2 \mathrm{~m}$ thick. G) Cuspate indentation in the roof of the Slaufrudalur Pluton, SSE of Skeggtindur $954 \mathrm{~m}$ a.s.l. Dyke injection at the roof of the pluton led to the partial separation of a block of basalt that remains as roof pendant. View NNW. Diameter of roof pendant is around $10 \mathrm{~m}$. H) Peak of Skeggtindur $864 \mathrm{~m}$ a.s.l., seen from the NW. Below the roof contact, several m- to tens-of-m size basaltic xenoliths occur within the granite. These we interpreted as stoped blocks.

metres thickness within the first metre of the roof rock, which are oriented parallel to the roof contact. However, we did not observe spalling of the roof originating from these sheets, or an upward growth of the pluton by incorporating roof rock by sheeting, as discussed by Glazner and Bartley (2006, 2008).

Examples of sections through the pluton roof are the northern and eastern slopes of the Skeggtindar, east of the eastern Skeggil, and the upper Gjádalur. There, features such as those described above and shown in Figure 5.13 can be observed. In addition, the contact on the crest north of Skeggtindur $954 \mathrm{~m}$ a.s.l. to the east is characterised by a fault and alteration zone around 10 to $20 \mathrm{~m}$ thick. There, the roof of the pluton loses more than $50 \mathrm{~m}$ of height. A 5 to $15 \mathrm{~m}$ high, vertical wall, composed of basaltic fault breccia, flanks the contact to the granite which shows signs of subsolidus deformation. On the side of the breccia wall facing the host rock, the basaltic host rock is altered in a narrow zone of maximum $10 \mathrm{~m}$ thickness. Another large step is located on the pass between Skeggtindur $954 \mathrm{~m}$ a.s.l. and Skeggtindur $864 \mathrm{~m}$ a.s.l., where the granite crops out for some metres and the roof contact is exposed around $100 \mathrm{~m}$ lower on the northern slope of Slaufrudalur. These two examples represent the largest exposed offsets in the roof with vertical displacements exceeding $50 \mathrm{~m}$. In general, the sizes of stoping features in the pluton roof range from a few decimetres to a few tensof-metres.

At sample-scale, the roof contact is knifesharp and straight. The basalt exhibits a glassy appearance within centimetres to a few metres from the contact. Beswick 

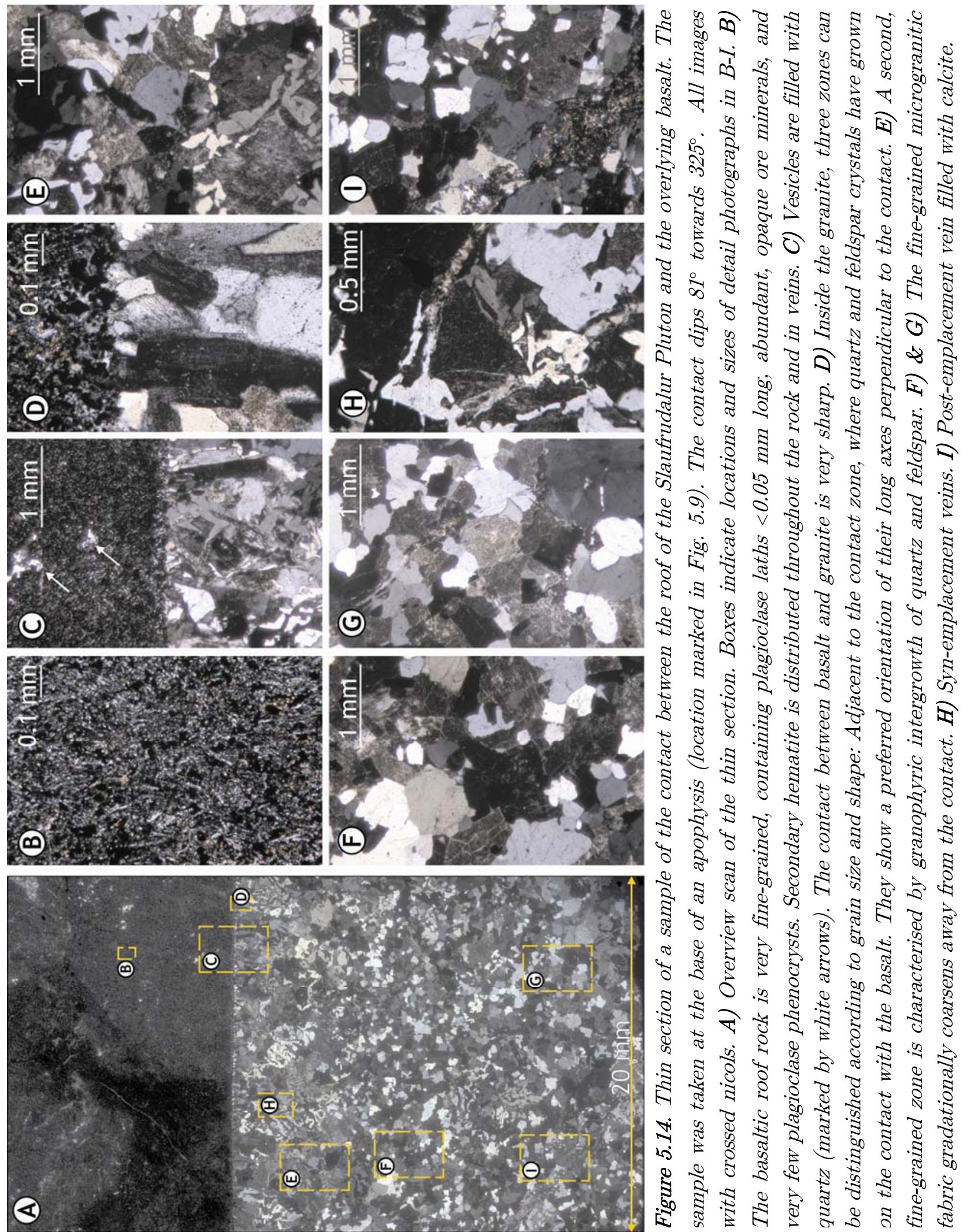

(1965) reported the occurrence of epidote veins and vesicles to a maximum distance of $100 \mathrm{~m}$ from the contact. At micro-scale, the very fine-grained basalt is crossed by a number of hematite and epidote veins; vesicles are filled with quartz (Fig. 5.14C). Ore minerals in a matrix of submicroscopic quartz crystals seal the contact 
on the basalt side. Towards the granite, the occurrence of quartz stops abruptly and there is a zone where small quartz and feldspar crystals grow with their long axes perpendicular to the contact (Fig. 5.14C \& D). This preferred orientation of crystals, along with the small grain size, can also be found in the granite within the first millimetres. Further away from the contact, the grain size increases relatively abruptly to a fine-grained microgranite following a zone characterised by granophyric intergrowth between quartz and feldspar (Fig. 5.14E-G). Within the granite, there are two co-genetic sets of veins with an anastomosing geometry, one parallel and one at an obtuse angle (but not perpendicular) to the contact plane (Fig. 5.14H). Where these veins cut the grains, quartz crystals are fractured, whereas within feldspar the veins are filled with calcite. Later (probably postemplacement) veins are filled with epidote.

\subsubsection{Internal structure}

For a detailed study of the internal structure of the Slaufrudalur Pluton, we also sampled its interior in regular vertical intervals. In accordance with observations of Beswick (1965) and Carmody (1991), we found that the pluton consists of macroscopically dissimilar varieties of microgranite and granophyre with varying colours, fabrics, and mineralogical composition. However, we could not define transitions or discrete interfaces between individual units. The results of more detailed mapping of the internal layering by Beswick (1965) and Carmody (1991) showed that on outcrop scale, transitions between layers are generally indistinct and can be (1) gradual, (2) characterised by mingling, or (3) show chilling of one unit against the next.

Furthermore, some of our samples contain mm- to cm-size basaltic xenoliths analogously to the occurrence of xenolithic talus reported by Carmody (1991). In general, the bulk of the pluton's volume, however, appears to be free of larger roof or wall rock xenoliths, except for a few msize xenoliths near the roof below Skeggtindur $864 \mathrm{~m}$ a.s.l. (Fig. 5.13H) and in a few other locations. Together they make up much less than $1 \%$ of the exposed area of the pluton.

Only one outcrop in a river bed in a canyon southwest of the peak of Bleikitindur near Endalausidalur is characterised by the occurrence of large volumes of basaltic xenoliths (Fig. 5.15). There, xenoliths make up $41 \%$ of the area of a horizontal outcrop. Three-dimensional sections further upriver indicate that the volume proportion of xenoliths is similar. It should be noted that the xenoliths are nearly indiscernible in a dry outcrop, so that a similar xenolith accumulation was only found further downstream in Endalausidalur, at approximately the same elevation as in the canyon. Within the canyon, in a horizontal outcrop of $64 \mathrm{~m}^{2}$ (but also in vertical section), the following features can be observed (Fig. 5.15): (1) The basaltic xenoliths do not show any shape-preferred orientation, and possess highly irregular shapes (Fig. 5.15A). (2) 
Figure 5.15. A) Sketch of a horizontal outcrop $\left(64 \mathrm{~m}^{2}\right)$ in a canyon southwest of Bleikitindur near Endalausidalur. $41 \%$ of the outcrop is occupied by basaltic xenoliths (in grey). These show highly irregular shapes and no preferred orientation. B) Detail photograph of a xenolith with crenulated parallel veins (marked by white arrows). Veining has resulted in spalling in the upper part of the image, so that the xenolith broke into cm-size fragments. Hammer
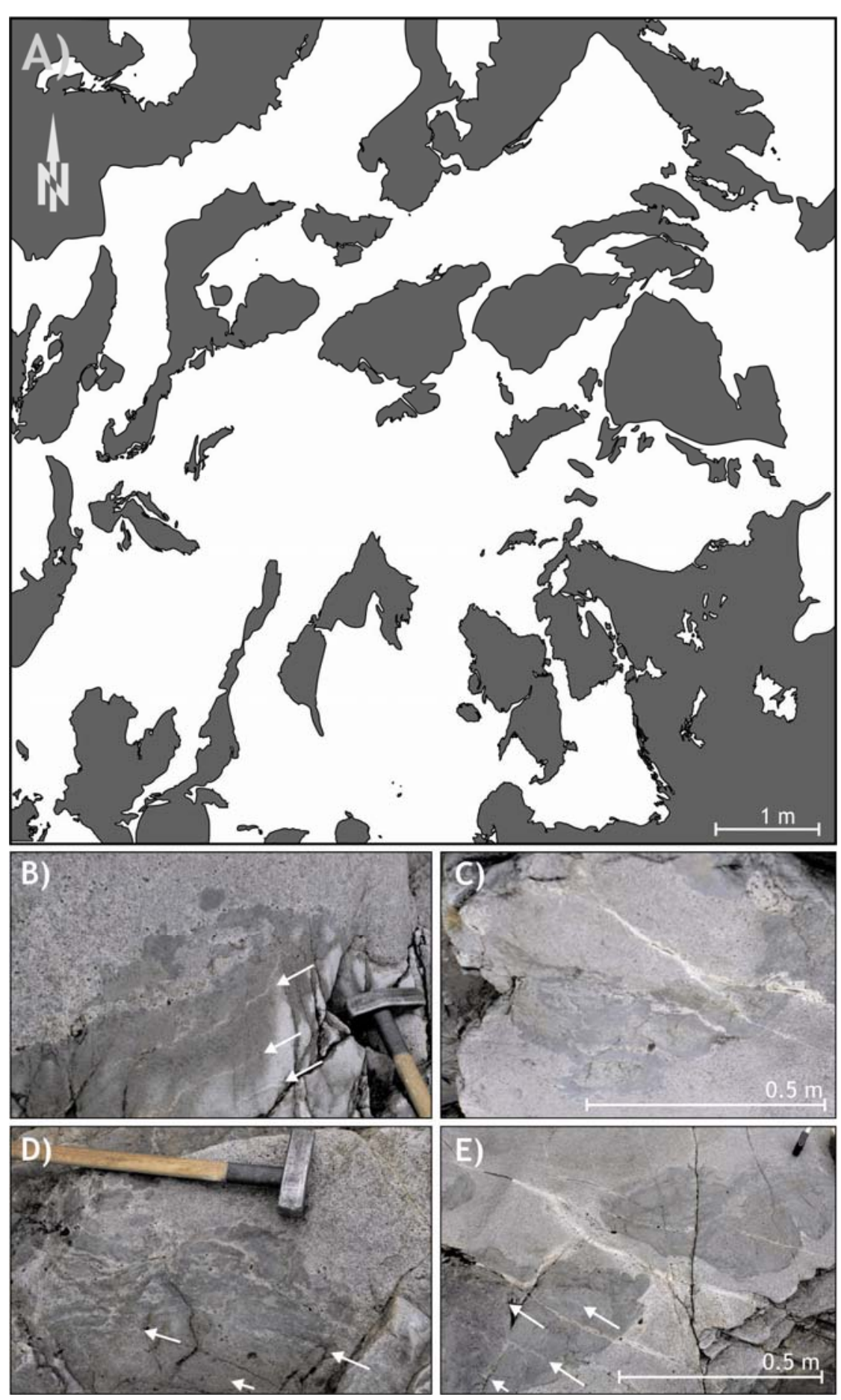

head is $10 \mathrm{~cm}$ long. C) Photograph of a xenolith with cloudy, altered margin. The xenolith has disintegrated into several smaller fragments that have been separated by the intrusion of granitic melt. A younger pegmatitic vein crosses the outcrop. D) De-tail photograph of the mar-gin of a xenolith with distinct spalling parallel to an indistinct foliation in the basaltic xenolith (marked by white arrows). Hammer head is $10 \mathrm{~cm}$ long. E)

Photograph of two xenoliths with different marginal features: the xenolith in the lower left and part of the xenolith in the upper right show sharp contacts to the surrounding granite, whereas the other part of the margin of the upper xenolith is cloudy and surrounded by a halo, which marks the final stage of disintegration of the basalt. Younger pegmatitic veins cross the outcrop. A set of early crenulated veins is marked by white arrows.

Many of them exhibit mmthick light coloured mineral veins, which are parallel to each other and seem to trace a foliation or bedding plane within the basalt (Fig. 5.15B). (3) The xenolithic blocks exhibit spalling, which results in a fragmentation of the m-size blocks (Fig. 8B\&D). (4) Furthermore, the mineral veins are characterised by a small- 
scale crenulation folding that indicates brittle veining followed by ductile deformation during compression or volume loss. Marginal parts exhibit either a sharp contact to the surrounding granite, or, in most cases, distinct alteration and bleaching (Fig. 5.15C\&E).

The latter is accompanied by corroded, cloudy margins, which sometimes pass into folded schlieren in the granite. The interior of some xenoliths shows irregular domains of coarse-grained, entirely felsic material. These domains can be interpreted as partial melts of the hydrothermally-altered basalt xenoliths. They are associated with a set of cm-thick pegmatitic veins (Fig. 5.15C\&E) with cm-size miarolites.

\subsubsection{Interpretation and discussion}

\subsubsection{Emplacement mechanisms}

According to Paterson and Fowler (1993) and Zak et al. (2006), roofs of plutons and the transitions from pluton roofs to the wall contacts reflect the dominant nearfield material transport processed during magma emplacement. Furthermore, Rosenberger et al. (1995) and Hogan et al. (1998) showed that knowledge of the threedimensional shape of a pluton helps to constrain the mechanisms controlling its emplacement. Both sources of information are available for the Slaufrudalur Pluton. A model for its emplacement should therefore be able to explain the field observations and the shape of the pluton.

\section{- Cauldron subsidence}

In general, we agree with the emplacement model of Cargill et al. (1928), Beswick
(1965), and Carmody (1991) that cauldron subsidence/floor sinking was the main mechanism by which space was created for the Slaufrudalur Pluton. Their model agrees well with the traditional concept of cauldron subsidence developed by Clough et al. (1909) and Billings (1943) and described later by Roberts (1970) and Myers (1975), including subterranean foundering during magma intrusion along "bell-jar"/ring fractures without any significant lateral or upward vertical distortion of the surrounding country rock. Roberts (1970) even named Slaufrudalur as an example for an intrusion emplaced by cauldron subsidence. Torfason disagreed with Roberts (1970) and showed Slaufrudalur as an elongated stock or diapir that domes up the surrounding lava pile. However we have not observed any distortion of the country rock in the direct vicinity of Slaufrudalur. Instead, the wall contacts of the pluton cut the lava flows at right angles (cf. Fig. 5.11 \& 5.12). In addition, the lacking "bell-jar" shape of the pluton roof mentioned by Torfason (1979) was satisfactorily explained by Beswick's (1965) interpretation of the roof contact as a cross fracture connecting the ring fractures and by Carmody's (1991) work illustrating the role of the directly overlying lava flow that probably arrested the propagation of the ring fracture and led to horizontal magma propagation (cf. Fig. 5.16A). Thus, the classic cauldronsubsidence model well explains the shape of the Slaufrudalur Pluton in cross section (Fig. 5.16A-D). Incremental subsidence of a horizontal pluton floor with filling of the 
pluton from the top down is also consistent with this shape (Cruden and McCaffrey, 2001).

However, the following observations still cannot be satisfactorily explained by a simple cauldron-subsidence model: (1) the map view shape of the pluton is not elliptical, as it would be expected of the trace of a ring fracture, but instead characterised by more or less angular transitions from walls parallel to long axes to walls parallel to short axes (Figs. $5.9 \&$ 5.10); (2) the occurrence of breccias only at walls parallel to the short axes. To adjust the simple cauldron-subsidence model for the emplacement of the Slaufrudalur Pluton, regional-tectonic and structural information must be taken into consideration (cf. Hutton, 1988). Figure 5.8 illustrates the trend of more or less contemporaneous intrusion swarms in the area surrounding Slaufrudalur, from which the direction of regional extension at the time of their formation can be deduced. For Slaufrudalur, the trend of intrusions from the contemporaneous Austurhorn and Vesturhorn complexes should be most significant. However, systematic studies of the structures in these two areas are lacking.

Further information could be gained from data from the area of the Lón Volcano that probably predates the Late Tertiary complexes of Austurhorn, Vesturhorn, Reydará, and Slaufrudalur ${ }^{2}$ (cf. Walker, 1966).

${ }^{2}$ Geochronological dating of the Tertiary volcanic activity in Southeast Iceland is still in a preliminary stage since the approaches of Gale et al. (1966), Moorbath et al. (1968), and Áberg et al. (1987). In
The main trend of minor intrusions in the Lón Volcano that best reflects the maximum horizontal stress direction is 025 (Fig. 5.8B; Torfason, 1979). This coincides well with the strike direction of the long axes of Slaufrudalur $\left(\sim 20^{\circ}\right)$; the elongated shape and orientation of the latter is therefore most probably inherited from regional structures (fissure swarm).

Also pre-existing regional structures have been recognised to have a major influence on the formation of elliptical collapse calderas. This results in reactivation of regional faults to form caldera ring-faults and consequently the creation of a polygonal outline of the calderas (Acocella et al., 2004; Holohan et al., 2005). The reason for the contrasting nature of the walls parallel to the long and the short axes remains, however, speculative. Results of analogue experiments (Holohan et al., 2008) and field observations of calderaforming eruptions (e.g. Wilson and Hildreth, 1997) indicate that upwardpropagating ring faults preferably reach the surface first at the sides parallel to the later long-axis of the finally elliptical caldera, before lateral propagation leads to linkage of the caldera.

Applying this model to the Slaufrudalur Pluton, lateral ring-fault propagation parallel to the regional strike culminated in linkage in the south (except maybe in the area where the fault breccia occurs), whereas in the northwest, linkage occurred

most cases, the relative ages of volcanoes are only known by means of stratigraphy. Here, age relations are derived from Walker $(1966 ; 1974)$ and Torfason (1979). 
by formation of a step-over that forms the straight brittle fault zone (Fig. 5.16J). In this context, the role of the thick granitic dyke in extension of the fault zone in the northeast is debateable.

\section{- Magmatic stoping}

Based on a thorough investigation of the roof structures on various scales, we conclude that magmatic stoping did indeed play a more significant role during em-
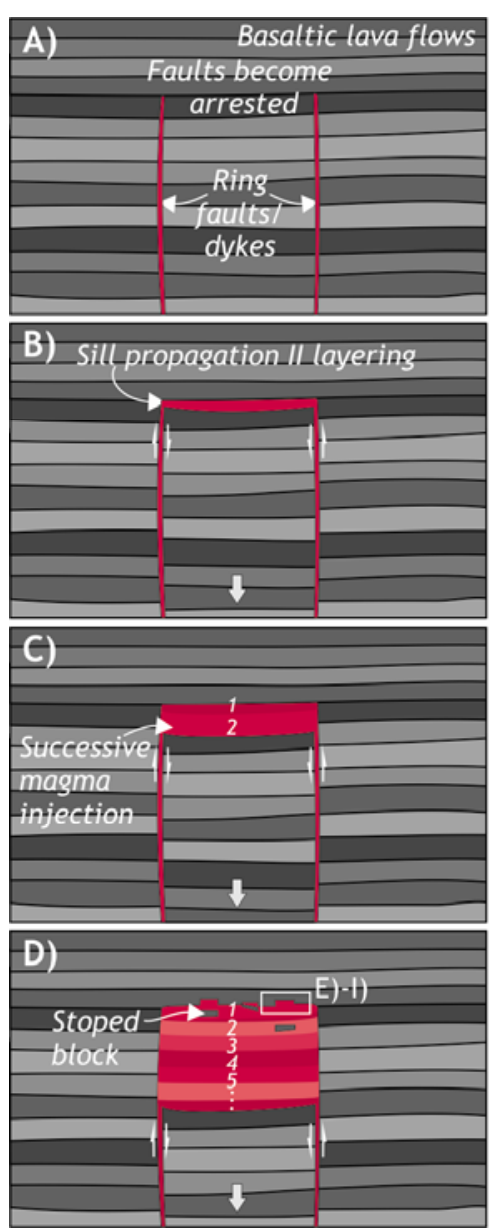
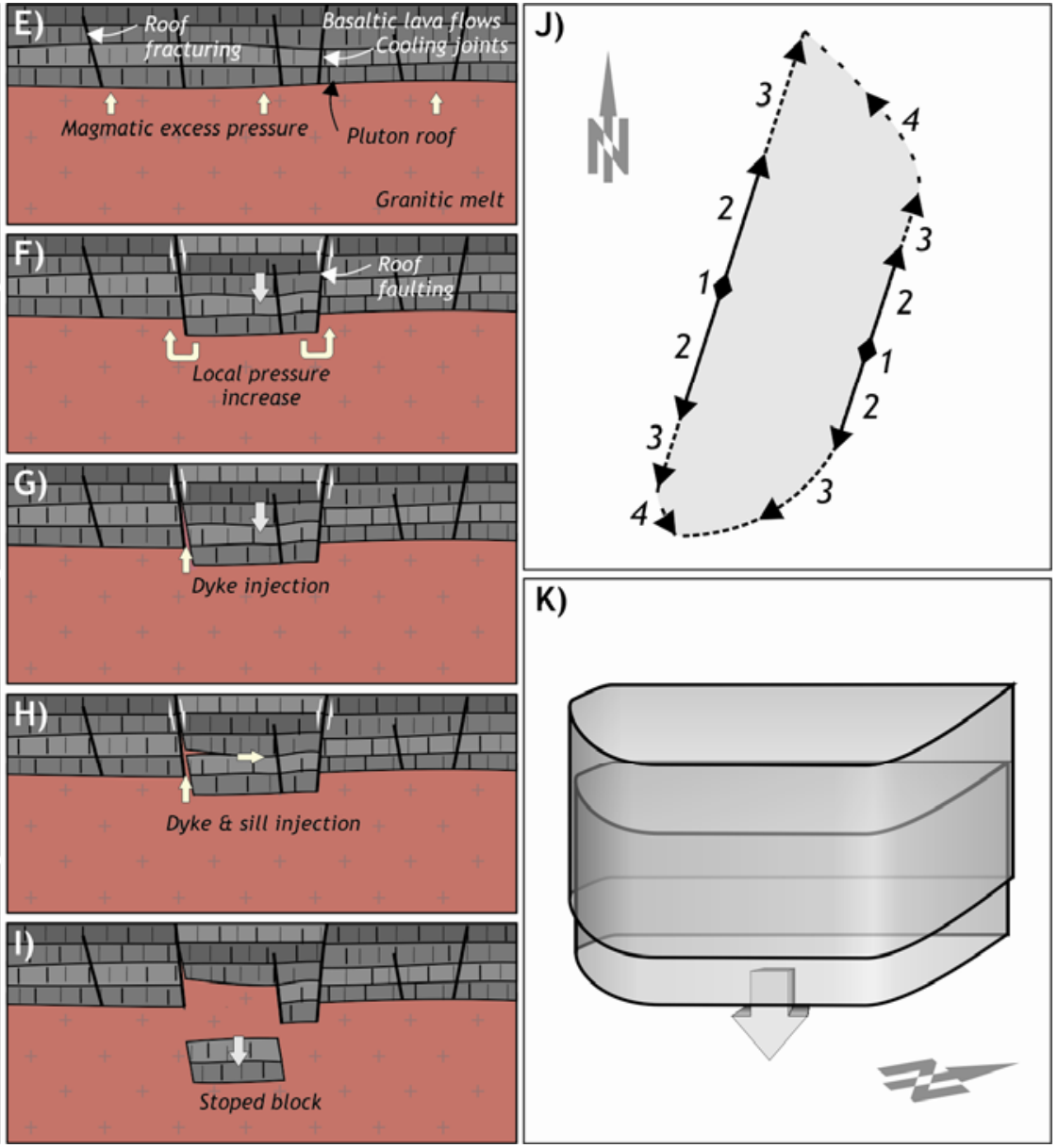

Figure 5.16. Emplacement model for the Slaufrudalur Pluton. A)-D) Schematic sketch of the process of cauldron subsidence above a larger magma chamber (not shown), in the case of Slaufrudalur. Note that successive magma batches intrude the previously-injected intrusive units from below (C\&D; intrusion order indicated by white numbers). E)-I) Schematic sketch of the process of magmatic stoping as observed in the Slaufrudalur Pluton (compare Fig. 5.13). The main mechanisms involved are probably shear and tensile failure (cf. Roberts, 1970) driven by hydraulic and thermal stresses. J) Concept of horizontal ring-fault propagation in map view. (1) Point at which upward ring-fault propagation first reaches the intrusion level. (2) Ring faults propagate laterally parallel to the regional trend of fissure swarms (cf. Fig. 5.8). (3) Further lateral propagation. (4) In the south, the ring fault closes mostly by a bending in the propagation path, whereas in the northeast, the ring faults link by a right-lateral step-over; K) Schematic sketch of the resulting three-dimensional geometry of the subsiding cauldron. The void created was filled with magma. 
placement of the Slaufrudalur Pluton than suggested by Cargill et al. (1928), Beswick (1965), and Carmody (1991). To estimate the efficiency of magmatic stoping in comparison with cauldron subsidence, we will now discuss what the roof structures reveal about the process of magmatic stoping, and what impact stoping had on the pluton's shape, to assess the quantitative contribution to space creation. The extraordinary quality of the outcrops (Fig. 5.12) allows reconstruction of the processes related to magmatic stoping in the case of Slaufrudalur (Fig. 5.16): An initial stage of roof fracturing above the pluton, while under cauldron subsidence, created a conjugate fracture set in the roof basalt (compare Fig. 5.16E with Figs. 5.11, 5.12, and 5.13A). Occasional normal faulting along the conjugate fractures resulted in local misbalance of the internal magmatic pressure regime (Fig. $5.16 \mathrm{~F}$ and $5.13 \mathrm{~B})$. In places, this led to the injection of magma along the faults (preferentially along one fracture set; compare Fig. 5.16G with Figs. 5.11 and 5.13C\&E). We can only speculate if a non-uniform subsidence of the pluton floor caused only one of the fracture sets to open as the result of simple shear. Furthermore, it is conspicuous that dykes never reach very far into the roof rock and that there are very few apophyses that are not associated with roof faulting (e.g. Fig. 5.13D). This indicates that the overall magmatic pressure inside the pluton was rather low as a result of magma replenishment accommodated by floor sinking and that dyke emplacement was actually the result of local faulting of the roof rocks. The original layering of the basalts provided abundant weak interfaces for the injection of sills, fed from the apophyses (compare Fig. 5.16H and Fig. $5.13 \mathrm{~F})$. Continued roof fracturing associated with dyke and sill injection gave rise to partial or complete detachment of roof blocks (Fig. 5.16I), which can be found as roof pendants and xenoliths, respectively (Fig. $5.13 \mathrm{G} \& \mathrm{H}$ ). In addition, the occurrence of contact-parallel granitic veins and thin sills above the roof can probably be attributed to thermal stresses around the pluton resulting in circumferential fracturing of the roof rock. According to Pignotta and Paterson (2007), stoping can result from e.g. thermal cracking, dyking, tectonic stresses, or focused porous flow that causes shear or tensile failure (Roberts, 1970). In the case of Slaufrudalur, stoping was probably due to the combined effect of internal magma pressure and ancillary thermal shock, faulting due to regional extension and gravity, and dyking.

It can be assumed that stoping affected the whole roof of the Slaufrudalur Pluton. Since the three-dimensional shape of the pluton roof is known, we are not restricted to estimate the extent to which magmatic stoping contributed to space creation from the volume of exposed xenoliths, as is the case of most other plutons (e.g. Wang et al., 2000; Bachl et al., 2001; Yoshinobu et al., 2003). Hence, we have the possibility to determine the role of stoping from its impact on the pluton's shape (cf. Zak et al., 2006) and compare it with the volume of exposed xenoliths. The topographic high 
around Skeggtindur $954 \mathrm{~m}$ a.s.l. represents the only deviation from the otherwise flat roof geometry and might thus be a result of magmatic stoping. The size of steps in the pluton roof also indicates that the effects of stoping are mostly in the range of $10^{0}$ to $10^{1} \mathrm{~m}$ and thus below the resolution of the three-dimensional model $\left(10^{1}-10^{2} \mathrm{~m}\right.$; Section 5.1; Burchardt et al., 2009). On this scale, stoping did not have a large impact on the shape of the intrusion. We assessed the problem using an analysis of the two-dimensional cross section ${ }^{3}$ shown in Figure 5.11 (Zak et al., 2006), based on the assumption that the pluton roof was originally entirely flat within the limits of the smoothness of the basaltic lava flow which formed the original roof (cf. Carmody, 1991). The amount of stoped material in the $8 \times 10^{5} \mathrm{~m}^{2}$ area in the cross section covers between $3.6 \times 10^{4} \mathrm{~m}^{2}$ and 5.2 $\times 10^{4} \mathrm{~m}^{2}$. Extrapolating the lesser of the two numbers to the full length of the main Slaufrudalur Pluton $(7300 \mathrm{~m})$ gives a stoped block volume of $2.6 \times 10^{9} \mathrm{~m}^{3}$, which is 26 to $32.5 \%$ of the exposed volume of the

\footnotetext{
${ }^{3}$ The area affected by stoping was estimated by an analysis of the area above a relatively smooth surface below the roof representing the original roof contact compared to the overall area of granite included in the cross section in Figure 4 using a grid with $10 \mathrm{~m}$ spacing. The minimum value takes into account a step-and-stair geometry of the original roof as known from e.g. the Whin Sill, United Kingdom (Francis, 1982) although this slightly contradicts Carmody's (1991) assumption that the roof was formed by a single competent lava flow. The maximum estimated value is adjusted to a more straight original roof contact with fewer transgressions.
}

pluton (8 to $10 \mathrm{~km}^{3}$ ). Although this amount is probably an overestimation since it is based on a rough approximation and does e.g. not take into account the role of roof faulting, it lies within the range for space creation by stoping in other plutons (Paterson and Fowler, 1993; Paterson and Vernon, 1995; Gerbi et al., 2004).

The amount of stoped material estimated from the roof geometry exceeds by far the volume of basaltic xenoliths (the small xenoliths reported by Carmody (1991) not considered, see below). Xenoliths are indeed scarce; very few can be found metres to a few hundred metres below the roof contact and range in size from decimetres to a few tens of metres. However, their cumulative area is much less than $1 \%$ of the exposed area of the pluton. Only the outcrop described in Section 5.2.3.4 and illustrated in Figure 5.15 is an exception. This outcrop probably represents a "graveyard" of roof xenoliths, rather than an injection of basaltic magma into the granitic pluton because: (1) the blocks show foliation or layering; (2) brittle deformation (veining), probably during stoping, was followed by ductile deformation, when the xenoliths were exposed to the granitic melt over a longer time; (3) an injection of basaltic magma into the granitic magma would have caused chilling of the basaltic and overheating of the granitic magma with different enclave shapes (generally rounded) and features commonly observed in net-veined complexes such as Austurhorn or Vesturhorn (Blake, 1966; Mattson et al., 1986; Furman et al., 1992). However, the 
exposed volume of xenoliths in this outcrop cannot account for large volumes of stoped material. The fact that only two such outcrops (in the canyon and in Endalausidalur) were found is probably due to the instance that the xenoliths are almost indiscernible in a dry outcrop and because the locations are among the lowest exposed levels of the Slaufrudalur Pluton. Hence, there might be more "graveyard" levels that have so far not been recognised or that are located below the level of exposure.

In the case of the Slaufrudalur Pluton, the discrepancy between the amount of stoped material, estimated from roof structures and actually exposed as xenoliths may indicate that sinking, disintegration, and assimilation are efficient processes to remove large volumes of stoped material (Clarke et al., 1998; McLeod and Sparks, 1998) even though the latter two mechanisms may be not very effective in the case of basaltic xenoliths enclosed in silicic magma. For the basaltic roof rocks encapsulated within the granitic melt, temperatures were not high enough to completely assimilate or melt the stoped blocks, even though they are characterised by distinct alteration and also partial melting in some cases (see Section 3.4). According to Clarke et al. (1998), thermalstress fracturing responsible for magmatic stoping in the first place can also be responsible for mechanical disintegration of the stoped blocks. This process can produce small refractory fragments that are no longer able to sink through the magma and are chemically assimilated. This would provide an explanation for the occurrence of the small xenoliths found by Carmody (1991) at the base of some intrusive units. Even though these xenoliths show a different chemical signature to that of the roof rocks of the pluton, they provide evidence for stoping at a deeper level (probably in the magma reservoir below Slaufrudalur or in the ring dyke (Carmody, 1991). It might, however, be possible that xenolithic talus in outcrops other than the ones sampled, originates from the roof rocks. In contrast, xenoliths in the outcrop shown in Figure 5.15 originate most likely from stoping in the roof of the pluton. Detailed sampling and analysis throughout the pluton could provide valuable insights into this issue. Another likely explanation for the removal of stoped blocks from the exposed outcrops is sinking to the unexposed pluton floor. Although, according to Yoshinobu and Barnes (2008), incremental pluton growth is not incompatible with the removal of stoped xenoliths, the sinking of a large amount of stoped blocks to the floor of the Slaufrudalur Pluton raises the question: when did stoping occur and for how long? Old $\mathrm{K} / \mathrm{Ar}$ age determinations by Gale et al. (1966) yield a wide range, which is much longer than the time required to fill a pluton of this volume by continuous magma supply (cf. Cruden and McCaffrey, 2001) and also far longer than the maximum residence time of volcanoes in the active rift zone (around $1 \mathrm{Ma}$; Saemundsson, 1979). The incremental emplacement and internal structure (subhorizontal layering) of the Slaufrudalur 
granites rule out the existence of convection. In addition, this implies a steady heat supply from successive magma replenishment, which kept the volume of the pluton hot enough to still act as a fluid. Beswick (1965) and Carmody (1991) actually reported indistinct cooling seams between individual intrusive units on the one hand and mingling on the other hand; this suggests that time between successive injections was indeed considerable, but not long enough for solidification of previouslyemplaced magma batches. On the other hand, large volumes of sinking roof xenoliths would probably have disturbed the internal stratification of the magma body. The timing and duration of magmatic stoping therefore remain uncertain and clearly demand systematic age dating and a study of the internal structure of the pluton in the future.

\subsubsection{Correlation with other plutonic} complexes in the area

The Slaufrudalur Pluton is located in an direct vicinity to the contemporaneous complexes of Austurhorn and Vesturhorn and the granitic intrusion Reydará (Fig. 5.8). According to Furman et al. (1992), Austurhorn, Vesturhorn, Reydará, and Slaufrudalur were volcanic centres in a propagating rift segment, similar to the present-day East Volcanic Zone. This riftzone segment was active between 6-7 Ma and postdated the volcanoes of Alftafjördur, Breiddalur, and Thingmuli.

Furman et al. (1992) interpret the Austurhorn complex as the root of a central volcano because (1) there is a close connection between the occurrence of felsic rocks and central volcanoes (Walker, 1974); (2) there are numerous vertical dykes which transported magma towards the surface; (3) the occurrence of a hightemperature geothermal system (cf. Fridleifsson, 1983); and (4) the depth and size is similar to those of magma chambers beneath active central volcanoes in the present-day rift zone (e.g. Sturkell et al., 2006). These criteria certainly also apply to the intrusive complex of Vesturhorn (cf. Roobol, 1974); however, this is not completely the case for Slaufrudalur (and probably Reydará). Even though zones of intense hydrothermal alteration in the south and northeast of the intrusion (Fig. 5.9) may indicate the existence of a geothermal system related to the pluton, the dykes fed by Slaufrudalur were probably not able to transport magma to the surface, since they never reach very far into the roof rocks (cf. Section 4.1.2). As shown above, magma replenishment probably did not produce sufficient pressure within the pluton to fracture its roof and feed an eruption. Accordingly, all dykes/apophyses originating from the roof of the Slaufrudalur Pluton follow the conjugate fracture set that we proposed was created by magmatic stoping. In contrast, an intrusive sheet swarm fed by an overpressured magma chamber would form a cone-sheet swarm with a bowlshaped geometry, as observed for example in the eroded Geitafell Volcano (Burchardt and Gudmundsson, 2009) or Thverartindur Volcano further to the south (Fig. 5.8; Klausen, 2004). 
We propose that instead of being the root of an independent volcano, Slaufrudalur is an intrusion related to the much bigger complex of Vesturhorn. This is supported by the results of Carmody's (1991) petrological and geochemical analyses, which show that the magma of the Slaufrudalur Intrusion was formed by the recycling of crustal material within a deeper, mafic magma chamber. This chamber had a lifetime similar or rather longer than Slaufrudalur and was located below it. The proximity $(2.5 \mathrm{~km}$ to the southeast of Slaufrudalur), range of cooling ages $(4.5 \pm 1.1 \mathrm{Ma}$ to $9.5 \pm 1.6 \mathrm{Ma}$; Gale et al., 1966; Moorbath et al., 1968), and composition of the Vesturhorn Complex suggest that the intrusions are related and share a common magma source. The existence of this deeper magma chamber below Vesturhorn was proposed by Mattson et al. (1986), who demonstrated that an underlying magma body, which contained mafic magma below felsic, was the source of the rocks of the Vesturhorn net-veined complex. Hence, this composite magma chamber supplied magma to the gabbro bodies of Vesturhorn, as well as felsic magma that ascended to form the granophyric bodies of Vesturhorn and Slaufrudalur. Hence, Slaufrudalur probably represents a long-lived intrusion in the flank region or vicinity of the actual Vesturhorn Volcano. Analogously, the felsic Reydará Pluton may represent a flank intrusion of the nearby Austurhorn Volcano.

\subsubsection{Conclusions}

Based on a detailed investigation of the three-dimensional shape and structures that characterise the contact between the granitic Slaufrudalur Pluton and its basaltic host rock, we evaluated the mechanisms that controlled its emplacement. The overall rhomboidal shape with steep walls, a flat roof, and the lack of host-rock distortion, support the hypothesis that the main volume of the pluton was emplaced by cauldron subsidence, a mechanism that involves the sinking of a piston of rock, surrounded by a ring fracture, and accompanied by magma transfer from a deeper source into the void above the piston (Fig. 5.15). The map-view shape of the Slaufrudalur Pluton reveals a strong tectonic control, which resulted in elongation parallel to trend of the regional dyke and fissure swarms. In contrast, alignment and character of the walls parallel to the short axes of the pluton indicate complex fault interaction during horizontal ring-fault propagation.

A thorough investigation of the pluton roof shows that structures related to magmatic stoping such as roof fracturing and faulting, as well as the formation of granitic apophyses and sills, that in places, separate blocks of host rock supplied from the roof, are distributed all over the roof area of the Slaufrudalur Pluton. Based on our knowledge of the three-dimensional shape of the pluton and the excellent exposure, we estimate the amount of space created by magmatic stoping to be approximately $30 \%$ of the exposed volume. 
However, it is still unclear where the stoped blocks have gone, since host-rock xenoliths make up less than $1 \%$ of the exposed part of the pluton. Nevertheless, a possible storage level of roof xenoliths has been identified in the lowest exposed level of the pluton. There xenolithic material makes up $41 \%$ of the outcrop area. Hence, deeper, unexposed levels of the pluton might contain larger volumes of xenoliths.

From the observation that the magma body of Slaufrudalur probably never fed eruptions to the surface, we conclude that it was not the root of one of the late Tertiary volcanoes such as Austurhorn. Instead, Slaufrudalur was rather a longlived flank intrusion related to the Vesturhorn Volcano, with which it shared a common, deeper magma source.

\subsubsection{References}

Åberg, G., Bollmark, B., and Macintyre, R. M., 1987. Age of the Austurhorn intrusion; a netveined complex in southeastern Iceland. Geologiska Föreningens i Stockholm Förhandlingar 109, 291-294.

Acocella, V., Funiciello, R., Marotta, E., Orsi, G., de Vita, S., 2004. The role of extensional structures in experimental calderas and resurgence. Journal of Volcanology and Geothermal Research 129, 199-217.

Bachl, C. C., Miller, C. F., Miller, J. S., Faulds, J. E., 2001. Construction of a pluton: Evidence from an exposed cross section of the Searchlight pluton, Eldorado Mountains, Nevada. Geological Society of America Bulletin 113, 1213-1228.

Beswick, A. E., 1965. A study of the Slaufrudalur granophyre intrusion, South-East Iceland. Ph.D. Thesis, Imperial College, London, 284 pp.
Billings, M. P., 1943. Ring-dykes and their origin. Transactions of the New York Academy of Sciences, Series 2, 5, 131.

Blake, D. H., 1966. The net-veined complex of the Austurhorn intrusion, south-eastern Iceland. Journal of Geology 76, 891-907.

Burchardt, S., Gudmundsson, A., 2009. The infrastructure of Geitafell Volcano, Southeast Iceland. In: Thordarson, T., Larsen, G., Self, S., Rowland, S., Hoskuldsson, A. (eds.). Studies in Volcanology: The Legacy of George Walker. Geological Society, London, Special Publications, in press.

Burchardt, S., Tanner, D. C., Krumbholz, M., 2009. Mode of emplacement of the Slaufrudalur Pluton, Southeast Iceland inferred from threedimensional GPS mapping. Submitted to Tectonophysics.

Cargill, H. K., Hawkes, L., Ledeboer, J. A., 1928. The major intrusions of south-eastern Iceland. Quarterly Journal of the Geological Society of London 84, 505-539.

Carmody, R. W., 1991. The Slaufrudalur stock of southeast Iceland: Geology, Geochemistry and Petrogenesis. Ph.D. Thesis, Johns Hopkins University, Baltimore, $392 \mathrm{p}$.

Clarke, D. B., Erdmann, S., 2008. Is stoping a volumetrically significant pluton emplacement process?: Comment. Geological Society of America Bulletin 120, 1072-1074.

Clarke, D. B., Henry, A. S., White, M. A., 1998. Exploding xenoliths and the absence of 'elephants' graveyards' in granite batholiths. Journal of Structural Geology 20, 1325-1343.

Clough, C. T., Brantwood Maufe, H., Battersby Bailey, E., 1909. The cauldron-subsidence of Glen Coe, and the associated igneous phenomena. Quarterly Journal of the Geological Society of London 65, 611-678.

Cruden, A. E., McCaffrey, K. J. W., 2001. Growth of plutons by floor subsidence: Implications for rates of emplacement, intrusion spacing and melt-extraction mechanisms. Physics and Chemistry of the Earth (A) 26, 303-315.

Daly, R. A., 1903. The mechanics of igneous intrusion. American Journal of Science 15, 269298. 
Francis, E. H., 1982. Magma and sediment: 1. Emplacement mechanism of late Carboniferous tholeiite sills in northern Britain. Geological Society, London 139, 1-20.

Fridleifsson, G. O., 1983. The geology and the alteration history of the Geitafell central volcano, Southeast Iceland. Ph.D. Thesis, Grant Institute of Geology, University of Edinburgh, $371 \mathrm{pp}$.

Furman, T., Meyer, P. S., Frey, F., 1992. Evolution of Icelandic central volcanoes: evidence from the Austurhorn intrusion, southeastern Iceland. Bulletin of Volcanology 55, 45-62.

Gale, N. H., Moorbath, S., Simons, J., and Walker, G. P. L., 1966. K-Ar ages of acid intrusive rocks from Iceland. Earth and Planetary Science Letters 1, 284-288.

Gerbi, C., Johnson, S. E., Paterson, S. R., 2004. Implications of rapid, dike-fed pluton growth for host-rock strain rates and emplacement mechanisms. Journal of Structural Geology 19, 583-594.

Glazner, A. F., Bartley, J. M., 2006. Is stoping a volumetrically significant pluton emplacement process? Geological Society of America Bulletin 118, 1185-1195.

Glazner, A. F., Bartley, J. M., 2008. Reply to comments on „Is stoping a volumetrically significant pluton emplacement process?“ Geological Society of America Bulletin 120, 10821087.

Goodchild, J. G., 1892. Note on granitic junction in the Ross of Mull. Geological Magazine 9, 447451.

Hogan, J. P., Price, J. D., Gilbert, M. C., 1998. Magma traps and driving pressure: consequences for pluton shape and emplacement in an extensional regime. Journal of Structural Geology 20, 1155-1168.

Holohan, E. P., Troll, V. R., van Wyk de Vries, B., Walsh, J. J., Walter, T. R., 2008. Unzipping Long Valley: An explanation for vent migration patterns during elliptical ring fracture eruption. Geology 36, 323-326.

Holohan, E. P., Troll, V. R., Walter, T. R., Munn, S., McDonell, S., and Shipton, Z. K., 2005. Elliptical calderas in active tectonic settings: an experimental approach. Journal of Volcanology and Geothermal Research 144, 119-136.

Hutton, D. H. W., 1988. Granite emplacement mechanisms and tectonic controls: inferences from deformation studies. Transactions of the Royal Society of Edinburgh: Earth Sciences 79, 245-255.

Klausen, M. B., 2004. Geometry and mode of emplacement of the Thverartindur cone sheet swarm, SE Iceland. Journal of Volcanology and Geothermal Research 138, 185-204.

Mattson, S. R., Vogel, T. A., Wilband, J. T., 1986. Petrochemistry of the silicic-mafic complexes at Vesturhorn and Austurhorn, Iceland: Evidence for zoned/stratified magma. Journal of Volcanology and Geothermal Research 28, 197223.

McLeod, P., Sparks, R. S. J., 1998. The dynamics of xenolith assimilation. Contributions to Mineralogy and Petrology 132, 21-33.

Moorbath, S., Sigurdsson, H., and Goodwin, R., 1968. K-Ar ages of oldest exposed rocks in Iceland. Earth and Planetary Science Letters 4, 197.

Myers, J. S., 1975. Cauldron subsidence and fluidization: Mechanisms of intrusion of the Coastal Batholith of Peru into its own volcanic ejecta. Geological Society of America Bulletin 86, 1209-1220.

Paquet, F., Dauteuil, O., Hallot, E., Moreau, F., 2007. Tectonics and magma dynamics coupling in a dyke swarm of Iceland. Journal of Structural Geology 29, 1477-1493.

Paterson, S. R., Fowler, T. K., Jr., 1993. Reexamining pluton emplacement processes. Journal of Structural Geology 15, 191-206.

Paterson, S. R., Tobisch, O. T., 1988. Using pluton ages to date regional deformations: Problems with commonly used criteria. Geology 16, 11081111.

Paterson, S. R., Vernon, R. H., 1995. Bursting the bubble of ballooning plutons: A return to nested diapers emplaced by multiple processes. Geological Society of America Bulletin 107, 13561380.

Paterson, S. R., Pignotta, G. S., Farris, D., Memeti, V., Miller, R. B., Vernon, R. H., Zák, J., 2008. Is 
stoping a volumetrically significant pluton emplacement process? Discussion. Geological Society of America Bulletin 120, 1075-1079.

Pignotta, G. S., Paterson, S. R., 2007. Voluminous stoping in the Mitchell Peak granodiorite, Sierra Nevada Batholith, California. Canadian Mineralogist 45, 87-106.

Roberts, J. L., 1970. The intrusion of magma into brittle rocks. In: Newall, G., Rast, N. (eds.), Mechanism of Igneous Intrusion. Geological Journal Special Issues 2, 287-338.

Roobol, M. J., 1974. The geology of the Vesturhorn intrusion, SE Iceland. Geological Magazine 111, 273-285.

Rosenberg, C. L., Berger, A., Schmid, S. M., 1995. Observations from the floor of a granitoid pluton: Inferences on the driving force of final emplacement. Geology 23, 443-446.

Saemundsson, K., 1979. Outline of the geology of Iceland. Jökull 29, 7-28.

Sturkell, E., Einarsson, P., Sigmundsson, F., Geirsson, H., Olafsson, H., Pedersen, R., de Zeeuw-van Dalfsen, Linde, A. T., Sacks, S. I., and Stefansson, R., 2006. Volcano geodesy and magma dynamics in Iceland. Journal of Volcanology and Geothermal Research 150, 1434.

Torfason, H., 1979. Investigations into the structure of south-eastern Iceland. Ph.D. Thesis, University of Liverpool, Liverpool, 589 pp.

Walker, G. P. L., 1966. Acid volcanic rocks in Iceland. Bulletin of Volcanology 29, 375-402.
Walker, G. P. L., 1974. The structure of eastern Iceland. In: Kristiansson, L. (ed.), Geodynamics of Iceland and the North Atlantic Area. Reidel, Dordrecht, 177-188.

Wang, T., Wang, X., Li, W., 2000. Evaluation of multiple emplacement mechanisms: the Huichizi granite pluton, Qinling orogenic belt, central China. Journal of Structural Geology 22, 505518.

Wilson, C. J. N., Hildreth, W., 1997. The Bishop Tuff: new insights from eruptive stratigraphy. Journal of Geology 105, 407-439.

Yoshinubo, A. S., Barnes, C. G., 2008. Is stoping a volumetrically significant pluton emplacement process? Discussion. Geological Society of America Bulletin 120, 1080-1081.

Yoshinubo, A. S., Fowler, T. K., Paterson, S. R., Llambias, E., Tickyi, H., Sato, A. M., 2003. A view from the roof: magmatic stoping in the shallow crust, Chita pluton, Argentina. Journal of Structural Geology 25, 1037-1048.

Zak, J., Holub, F. V., Kachlik, V., 2006. Magmatic stoping as an important emplacement mechanism of Variscan plutons: Evidence from roof pendants in the Central Bohemian plutonic complex (Bohemian Massif). International Journal of Earth Sciences 95, 771-789. 


\section{Summary and outlook}

The case studies included in this thesis (Chapters 3 to 5) aim to enhance the understanding of different mechanisms of magma emplacement in the upper crust based on the analysis of field examples and the use of analogue and numerical modelling. As such, the results presented in these chapters provide further insight into the main questions addressed in this thesis, namely (1) the mechanisms that control magma emplacement in the upper crust; (2) the influence of the host-rock structure on the emplacement of magma; (3) the influence magma emplacement has on the host rock; and (4) how large magma bodies can form in the upper crust.

\subsection{Summary and discussion of Chapter 3}

Chapter 3 describes the results of field analysis of the Njardvik Sill in Northeast Iceland. This example of an extraordinarily well-exposed sill in the Tertiary Dyrfjöll Volcano provides valuable insight into its feeding relationships, the mechanical conditions of its emplacement, the mode of magma supply, and the mechanical effect of its emplacement on its surroundings. It allows thus more general conclusions about the mechanism of sill emplacement.

The Njardvik Sill is fed by at least eight basaltic inclined sheets that intruded the interface between a subvolcanic rhyolitic intrusion and overlying, more rigid, basaltic lava flows. The sill consists of at least seven individual units, each fed by an inclined sheet, the injection frequency of which was too low so that effective mixing and homogenisation of the magma was prevented. The initiation of the Njardvik Sill created a local stress field in its vicinity that deflected subsequently injected inclined sheets and a dyke into a sill-parallel orientation. The numerical model that was built based on the structural configuration of the Njardvik Sill aimed at a simulation of the mechanical conditions and effects of the initiation of the first sill unit and demonstrates that an inclined sheet can be deflected into a sill when meeting a weak interface between layers of different properties and that the resulting stress field favours the emplacement of subsequent sills below the first one.

General implications that arise from this study include that inclined sheets can serve as feeders for sills in stratovolcanoes. There, layers composed of materials with contrasting mechanical properties and abundant weak interfaces between these layers favour sill emplacement because they may cause a local rotation of the principal stress directions. Sill emplacement itself can then increase the sphere of influence of this stress field with a horizontal orientation of the maximum principal compressive stress $\sigma_{1}$ which attracts the emplacement of further sills adjacent to the first one. Consequently, the sill can grow and eventually expand into a laccolith. However, if the magma- 
supply rate is low, individually emplaced sill unit will maintain their physical integrity resulting in a sheeted structure of the intrusive body.

Therefore, the study of the Njardvik Sill can join the series of the latest studies on sills that reflect the increased amount of attention sill emplacement has received lately because of its well-known significance in volcanology (e.g. Auger et al., 2001) and the recently discovered role it plays in groundwater circulation (Chevalier et al., 2001), the evolution of hydrocarbon reservoirs in sedimentary basins (Jones et al., 2007; Svensen et al., 2008) and global climate change (Svensen et al., 2008). Latest research therefore focuses on the study of the geometry and feeding relationships of sills using threedimensional seismic studies (e.g. Hansen et al., 2004; Thomson and Hutton, 2004; Hansen and Cartwright, 2006; Fernandes et al., 2008). In addition, the study of the geometry, structure, and geochemistry of well-exposed sills and sill complexes is pursued (e.g. Galerne et al., 2008). The results serve as input parameters for analogue experiments (e.g. Kavanagh et al., 2006; Galland et al., 2008a, b) and numerical models (e.g. Niebling et al., 2008).

\subsection{Summary and discussion of Chapter 4}

Chapter 4 presents the results of a series of scaled analogue experiments that analyse the structural evolution of ring faults above a deflating magma reservoir. The experiments reproduce ring-fault structures in previous experimental studies including several sets of outward-dipping reverse ring faults and peripheral, inwarddipping normal ring faults (e.g. Roche et al., 2000). However, the application of digital image correlation and strainanalysis methods make it possible to visualise and quantify the process of ring faulting and to understand the complex interplay of ring-fault formation, propagation, and interaction.

After a period of initial surface downsag, the first set of reverse ring faults propagates in tandem from the periphery of the chamber analogue upwards and is characterised by the typical "bell jar" geometry. Subsequent sets of reverse ring faults develop in a more or less symmetric way depending on the roof aspect-ratio of the magma reservoir (roof thickness vs. width of the chamber). The transition from one set of ring faults to the next that typically flanks the former on its outer side is characterised by displacement transfer. The number of sets of reverse ring faults depends on the roof aspectratio. In contrast to the reverse ring faults, peripheral normal ring faults evolve from surfacial tension fractures that originate from the initial stage of surface downsag. The normal faults propagate downwards and interlink with segments of the reverse ring faults at depth. This implies that the normal ring faults are primarily developed as mode I fractures that evolve into shear fractures, while the reverse ring faults initiate at shear fractures that can become mixed-mode when intruded by magma. Furthermore, magma transport along the 
normal ring faults only occurs when interlinked with the reverse faults at depth.

In Chapter 4, the results of the experiments are used as an approach to interpret the seismically-recorded stages of ring faulting that preceded caldera collapse of Miyakejima Volcano in 2000. In addition, the experimental results that show a complex structural configuration and evolution of ring faults above a deflating magma reservoir, including the sequential activation and inactivation of ring faults connected with episodic magma transport, bears implications for the formation of ring complexes as well as for vent migration during eruptions in caldera volcanoes. The emplacement of "bell jar" intrusions described by the mechanism of cauldron subsidence is probably controlled by the first set of reverse ring faults that detach a block of roof rock and become intruded by magma. This is in agreement with Branney's (1995) suggestion that “bell jar" intrusions represent an immature stage of ring faulting.

The methodological approach presented in Chapter 4 therefore offers additional insight into the kinematics of ring faulting and represents thus a necessary further development of the well-established technique to study collapse calderas in analogue experiments (cf. Acocella, 2007, 2008). In addition, the results are confirmed by their striking resemblance to discrete element models by Hardy (2008).

\subsection{Summary and discussion of Chapter 5}

Due to the excellent exposure conditions in the area, the Slaufrudalur Pluton, Southeast Iceland, is an ideal subject for an investigation of magma-emplacement mechanisms in the upper crust. The study of this pluton outlined in Chapter 5 combines the classic approach to study emplacement-related structures in and around plutons with a new technique to reconstruct the three-dimensional shape of a pluton based on high-precision GPSmapping. Therefore, it was not only possible to identify the magmaemplacement mechanisms involved - as had been done by earlier studies (e.g. Cargill et al., 1928), but also to quantify the volumetric contribution of individual mechanisms. The latter is attempted increasingly in studies of plutons (e.g. Wang et al., 2000; Zak et al., 2006) since the significance of the combination of several emplacement mechanisms has been reinforced e.g. by Paterson and Fowler (1993). In the case of magmatic stoping, the estimation of volumetric contribution is still subject to vigorous debate (Glazner and Bartley, 2006, 2008; Clarke and Erdmann, 2008; Paterson et al., 2008; Yoshinobu and Barnes, 2008).

The main conclusions of the study in Chapter 5 include that the Slaufrudalur Pluton was initially emplaced by a form of cauldron subsidence influenced by regional tectonics and the layered structure of the basaltic host rock. Deflation of an underlying magma reservoir that also fed the adjacent Vesturhorn Volcano resulted 
in the formation of ring faults. The lateral propagation of the ring fault was strongly controlled by regional tectonic extension, while its upward propagation was arrested at the interface between two basaltic layers of the host rock. Through the mechanism of sill emplacement similar to the one described in Chapter 3, magma, transported along the ring fault, intruded the horizontal host-rock discontinuity. As a result, the piston of rock enclosed by the ring fracture was detached and began to subside into the underlying magma reservoir controlled by the episodic magma supply into the created void. The resulting geometry of the Slaufrudalur Pluton was characterised by steep walls and a flat roof that is a result of vertical ring-fracture arrest and subsequent sill propagation and in contrast to the "bell jar" geometry expected for plutons emplaced by cauldron subsidence (e.g. Roberts, 1970).

Thermal stresses induced by the temperature gradient between magma and host rock led to fracturing, faulting, and dyking of the pluton roof and, consequently, the detachment of blocks of roof rock by the mechanism of magmatic stoping. A balancing of the roof structures created by stoping indicates that around $30 \%$ of the exposed volume of 8 to $10 \mathrm{~km}^{3}$ of the Slaufrudalur Pluton was emplaced by magmatic stoping. However, the fate of the stoped material could not be satisfactorily explained, even though outcrops with a high volume percentage of basaltic xenoliths in the lowermost exposed parts of the pluton indicate that stoped material might have sunken below the level of exposure.

The Slaufrudalur Pluton is probably a unique example of a pluton in the upper crust as regards exposure conditions. The method of combined GPS-mapping and reconstruction of the three-dimensional shape of the pluton may thus be only applicable to a few other plutons worldwide. However, this method represents a valuable supplement to the study of emplacement-related structures since the shape of a pluton together with its roof and wall structures is characteristic of different emplacement mechanisms (cf. Rosenberg et al., 1995; Hogan et al., 1998). Furthermore, the enhanced understanding of the magmaemplacement mechanisms of cauldron subsidence and magmatic stoping from this study can contribute to a better understanding of the emplacement of other plutons as well.

\subsection{Outlook}

The case studies and methodological approaches presented in this thesis offer starting points for future research in the following fields:

o Field, theoretical, and experimental studies should further assess the properties of interfaces between rock strata and their influence on magma emplacement.

o Modelling should be used to investigate and quantify the influence of initial magma emplacement on subsequent magma injections. 
o In this context, thermo-mechanical models could shed light on the critical injection frequency for the growth and homogenisation of a magma body and the maintenance of the local stress field created around it.

o Additional parameters such as mechanically different layers or even weak interfaces could be introduced in analogue experiments of ring faulting such as the ones in Chapter 4 to analyse the influence of a heterogeneous crust overlying the magma chamber.

o Future research may answer the question what further insight into the mode of emplacement can be gained from the method of GPS-mapping and the reconstruction of the threedimensional shape of intrusions in the case of well-exposed intrusions.

o The interplay between different magma-emplacement mechanisms, such as e.g. cauldron subsidence and stoping, should be studied in more detail especially as regards timing and volumetric contribution of individual mechanisms and their interaction.

o A detailed study of the fate of basaltic xenoliths enclosed in granitic magmas (in contrast to previous studies with sedimentary rocks in granite magmas) could provide a better understanding of the process of disintegration and assimilation of stoped blocks in areas such as Iceland.

o A detailed structural study of the Lón area similar to the one by Torfason (1979) but with special emphasis on the relationship between the Tertiary volcanic centres and intrusions and regional tectonic structures could offer insight into the interaction of active volcanic centres in Iceland.

\subsection{References}

Acocella, V., 2007. Understanding caldera structure and development: An overview of analogue models compared to natural calderas. EarthScience Reviews 85, 125-160.

Acocella, V., 2008. Structural development of calderas: a synthesis from analogue experiments. In: Gottsmann, J., Marti, J. (eds.). Caldera Volcanism. Analysis, Modelling and Response. Elsevier, Amsterdam, 336 p.

Auger, E., Gasparini, P., Virieux, J., Zollo, A., 2001. Seismic evidence of an extended magmatic sill under Mt. Vesuvius. Science 294, 1510-1512.

Branney, M. J., 1995. Downsag and extension at calderas: new perspectives on collapse geometries from ice-melt, mining, and volcanic subsidence. Bulletin of Volcanology 57, 303-318.

Cargill, H. K., Hawkes, L., Ledeboer, J. A., 1928. The major intrusions of south-eastern Iceland. Quarterly Journal of the Geological Society of London 84, 505-539.

Chevallier, L., Goedhart, M., Woodford, A., 2001. The influence of dolerite sills and ring complexes on the occurrence of groundwater in the Karoo fractured aquifers: a morpho-tectonic approach. Water Resources Communications, South Africa 937, 143 pp.

Clarke, D. B., Erdmann, S., 2008. Is stoping a volumetrically significant pluton emplacement process?: Comment. Geological Society of America Bulletin 120, 1072-1074.

Fernandes, K., Jones, S., Hardy, R., 2008. Documenting igneous sills in the Irish sector of the North Atlantic Igneous Province. International Geological Congress, Oslo, August 6-14 2008, Abstract EUR08210.

Galerne, C. Y., Neumann, E. R., Planke, S., 2008. Emplacement mechanisms of sill complexes: 
Information from the geochemical architecture of the Golden Valley Sill Complex, South Africa. Journal of Volcanology and Geothermal Research 177, 425-440.

Galland, O., Planke, S., Neumann, E. R., MaltheSørensen, A., 2008a. Experimental modelling of the formation of saucer-shaped sills. International Geological Congress, Oslo, August 6-14 2008, Abstract MPV06809.

Galland, O., Planke, S., Neumann, E. R., Malthe-

Sørensen, A., 2008b. Dome structures above sills and saucer-shaped sills: insights from experimental modelling. International Geological Congress, Oslo, August 6-14 2008, Abstract MPV06812.

Glazner, A. F., Bartley, J. M., 2006. Is stoping a volumetrically significant pluton emplacement process? Geological Society of America Bulletin 118, 1185-1195.

Glazner, A. F., Bartley, J. M., 2008. Reply to comments on „Is stoping a volumetrically significant pluton emplacement process?“" Geological Society of America Bulletin 120, 1082-1087.

Hansen, D. M., Cartwright, J., 2006. Saucer-shaped sill with lobate morphology revealed by 3D seismic data: implications for resolving a shallow-level sill emplacement mechanism. Journal of the Geological Society, London 163, 509-523.

Hansen, D. M., Cartwright, J., Thomas, D., 2004. 3D seismic analysis of the geometry of igneous sills and sill junctions relationships. In: Davies, R. J., Cartwright, J. A., Steward, S. A., Lappin, M., Underhill, J. R. (eds.), 3D Seismic Technology. Application to the Exploration of Sedimentary Basins. Geological Society of London Memoir, pp. 199-208.

Hardy, S., 2008. Structural evolution of calderas: Insights from two-dimensional discrete element simulations. Geology 36, 927-930.

Hogan, J. P., Price, J. D., Gilbert, M. C., 1998. Magma traps and driving pressure: consequences for pluton shape and emplacement in an extensional regime. Journal of Structural Geology, 20, 1155-1168.
Jones, S. F., Wielens, H., Williamson, M. C., Zentilli, M., 2007. Impact of magmatism on petroleum systems in the Sverdrup Basin, Canadian Arctic Islands, Nunavut: a numerical modelling study. Journal of Petroleum Geology 30, 237-255.

Kavanagh, J. L., Menand, T., Sparks, R. S. J., 2006. An experimental investigation of sill formation and propagation in layered elastic media. Earth and Planetary Science Letters 245, 799-813.

Marti, J., Geyer, A; Folch, A., Gottsmann, J., 2008. A review on collapse caldera modeling. In: Gottsmann, J., Marti, J. (eds.), Caldera Volcanism, Volume 10 - Analysis, Modelling and Response. Elsevier, Amsterdam, 336 pp.

Niebling, M., Olivier, G., Sverre, P., Eirik, F., Anders, M., 2008. Numerical modelling of shallow hydraulic fracturing: Application to the formation of saucer-shaped fractures. International Geological Congress, Oslo, August 6-14 2008, Abstract MPV06816.

Paterson, S. R., Fowler, T. K., 1993. Re-examining pluton emplacement processes. Journal of Structural Geology 15, 191 - 206.

Paterson, S. R., Pignotta, G. S., Farris, D., Memeti, V., Miller, R. B., Vernon, R. H., Zák, J., 2008. Is stoping a volumetrically significant pluton emplacement process? Discussion. Geological Society of America Bulletin 120, 1075-1079.

Roberts, J. L., 1970. The intrusion of magma into brittle rocks. In: Newall, G., Rast, N. (eds.). Mechanism of Igneous Intrusion. Geological Journal Special Issues 2, 287-338.

Roche, O., Druitt, T. H., Merle, O., 2000. Experimental study of caldera formation. Journal of Geophysical Research 105, 395-416.

Rosenberg, C. L., Berger, A., Schmid, S. M., 1995. Observations from the floor of a granitoid pluton: Inferences on the driving force of final emplacement. Geology 23, 443-446.

Svensen, H., Planke, S., Corfu, F., 2008. Sill emplacement and contact metamorphism in the Vøring Basin during formation of the North Atlantic Volcanic Province and the implications for the PETM climate change. International 
Geological Congress, Oslo, August 6-14 2008, Abstract EUR08204.

Thomson, K., Hutton, D., 2004. Geometry and growth of sill complexes: insights using 3D seismic from the North Rockall Trough. Bulletin of Volcanology 66, 364-375.

Torfason, H., 1979. Investigations into the structure of south-eastern Iceland. Ph.D. Thesis, University of Liverpool, Liverpool, 589 p.

Wang, T., Wang, X., Li, W., 2000. Evaluation of multiple emplacement mechanisms: the Huichizi granite pluton, Qinling orogenic belt, central
China. Journal of Structural Geology 22, 505518.

Yoshinubo, A. S., Barnes, C. G., 2008. Is stoping a volumetrically significant pluton emplacement process? Discussion. Geological Society of America Bulletin 120, 1080-1081.

Zák, J., Holub, F. V., Kachlik, V., 2006. Magmatic stoping as an important emplacement mechanism of Variscan plutons: Evidence from roof pendants in the Central Bohemian plutonic complex (Bohemian Massif). International Journal of Earth Sciences 95, 771-789. 


\section{Curriculum Vitae}

Vor- und Zuname: Steffi Burchardt

Geburtsdatum und -ort: 22.07.1982 in Nordhausen

Nationalität: deutsch

Familienstand: ledig

\section{Ausbildung}

$03 / 2009$

$03 / 2006$

$07 / 2004$

$10 / 2001-03 / 2009$

$06 / 2001$

Promotion mit dem Thema „Mechanisms of magma emplacement in the upper crust“, Universität

Göttingen und Geoforschungszentrum Potsdam

Diplom Geowissenschaften, Universität Göttingen

Diplomarbeit: „Volcano-tectonic evolution of the

Geitafell Volcano, Southeast Iceland”

Diplomkartierung: „Report of the structural geology map of the Eastern Monte Freddone area, Alpi Apuane, Northern Apennine, Italy at the scale of $1: 5000$ “

Bachelor of Science Geowissenschaften, Universität

Göttingen

Bachelorarbeit: „Dyke emplacement in Tenerife

(Canary Islands): Field studies and numerical models”

Studium der Geowissenschaften an der Georg August Universität Göttingen

Abitur am staatlichen Gymnasium Wilhelm von Humboldt, Nordhausen 